Founder: Federal Scientific Center for Medical and Preventive Health Risk Management Technologies Federal Service for Surveillance on Consumer Rights Protection and Human Wellbeing

\section{Contact Information:}

82 Monastyrskaya Str.,

Perm, 614045, Russia

Tel/Fax: +7 (342) 237-25-34

E-mail: journal@ffcrisk.ru

Site: journal.fcrisk.ru/eng

Editor and corrector - M.N. Afanaseva Technical Editor - A.A. Nizhegorodova Translator - N.V. Dubrovskaya

All rights reserved. No part of this publication may be stored in the computer's memory or reproduced in any way without the prior written permission of the publisher.

The publication 30.03.2021.

Format $90 \times 60 / 8$.

Order No. 135/2021.

Edition is 500 copies.

The price is free.

The Journal is registered by The Federal Service For Supervision Of Communications, Information Technology, And Mass Media (Roscomnadzor). Register certificate СМИ - ПИ ㅇ. ФС 77-52552 issued on January 21, 2013

Address of the publisher and printing house: 29 Komsomolsky ave., Perm, 614990, Russia, tel.: +7 (342) 219-80-33

Printed by the Publishing House of Perm National Research Polytechnic University (29 Komsomolsky ave., Perm, 614990, Russia, tel.: +7 (342) 219-80-33)

\section{Subscription number: catalog "Russian Post" annual subscription -04153 semi-annual subscription $\mathbf{- 8 3 9 2 7}$}

ISSN (Print) 2308-1155

ISSN (Online) 2308-1163

ISSN (Eng-online) 2542-2308

This edition is provided financial support by the Perm Region Ministry for Education and Science

\section{HEALTH RISK ANALYSIS}

Theoretical and practical journal. Start of publication: 2013.

EDITORIAL BOARD

4 issues per year

G.G. Onishchenko - Editor in Chief, Fellow of the Russian Academy of Sciences, DSc, Professor (Moscow, Russia)

N.V. Zaitseva - Deputy Chief Editor, Fellow of the Russian Academy of Sciences, DSc, Professor (Perm, Russia)

I.V. May - Executive Secretary, DSc, Professor (Perm, Russia)

\section{EDITORS}

S.L. Avaliani - DSc, Professor (Moscow, Russia)

A.B. Bakirov - DSc, Professor (Ufa, Russia)

E.N. Belyaev - corresponding member of RAS, DSc, Professor (Moscow, Russia)

V.M. Boev - DSc, Professor, (Orenburg, Russia)

I.V. Bragina-DSc (Moscow, Russia)

R.V. Buzinov - DSc (Arkhangelsk, Russia)

I.V. Bukhtiyarov - corresponding member of RAS, DSc,

Professor (Moscow, Russia)

V.B. Gurvich - DSc (Ekaterinburg, Russia)

I. Dardynskaia - DSc, Professor (Chicago, USA)

MA. Zemlyanova - DSc (Perm, Russia)

U.I. Kenesariev - DSc, Professor, corresponding member of the Academy of Medical Sciences of Kazakstan (Almaty, Kazakstan)

T. Cronberg - DSc in Ec., DSc in Tec., Member of the European Parliament from Finland. (Ruveslahti, Finland)

S.V. Kuz'min - DSc, Professor (Ekaterinburg, Russia)

V.V. Kutyrev - Fellow of the Russian Academy of Sciences, DSc, Professor (Saratov, Russia)

V.R. Kuchma - corresponding member of RAS, DSc, Professor, (Moscow, Russia)

A.-M. Landtblom - MD PhD, Professor (Uppsala, Sweden)

Le Thi Hong Hao - Assoc., Professor (Hanoi, Vietnam)

A.G. Malysheva - DSc, Professor (Moscow, Russia).

A.V. Mel'tser - DSc, Professor (St.-Petersburg, Russia)

A.Ya. Perevalov - DSc, Professor (Perm, Russia)

Y.P. Pivovarov - Fellow of RAS, DSc, Professor (Moscow, Russia)

A.Yu. Popova - DSc, Professor (Moscow, Russia)

J. Reis - AEA Physiology, MD (Strasbourge, France)

V.N. Rakitskiy - Fellow of RAS, DSc, Professor, (Moscow, Russia)

Y.A. Revazova - DSc, Professor (Moscow, Russia)

V.S. Repin - DSc, Professor (St.-Petersburg, Russia)

A.V. Reshetnikov - Fellow of RAS, DSc, Professor (Moscow, Russia)

S.I. Savelyev - DSc, Professor (Lipetsk, Russia)

P. Spencer - PhD, FRCPath Professor Department of neurology (Portland, USA)

V.F. Spirin - DSc, Professor (Saratov, Russia) Director

A.Tsakalof - Professor of Medical Chemistry (Larissa, Greece)

V.A. Tutelyan - Fellow ofRAS, DSc, Professor (Moscow, Russia)

H.H. Hamidulina - DSc, professor, (Moscow, Russia)

S.A. Hotimchenko - DSc, professor (Moscow, Russia)

L.M. Shevchuk - PhD (Minsk, Belarus)

N.V. Shestopalov - DSc, Professor (Moscow, Russia)

P.Z. Shur - DSc, professor (Perm, Russia)
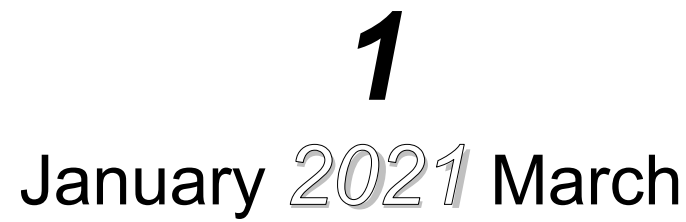


\section{Dedicated to the Year of Science and Technology}

\section{CONTENTS}

\section{PREVENTIVE HEALTHCARE: TOPICAL ISSUES OF HEALTH RISK ANALYSIS}

A.Yu. Popova, S.V. Kuzmin, N.V. Zaitseva, I.V. May PRIORITIES IN SCIENTIFIC SUPPORT PROVIDED FOR HYGIENIC ACTIVITIES ACCOMPLISHED BY A SANITARY AND EPIDEMIOLOGIC SERVICE: HOW TO FACE KNOWN THREATS AND NEW CHNALLANGES

N.E. Pil, V.M. Chigvintsev NUMERIC MODELING OF BACTERIA POPULATION EVOLUTION IN HUMAN LUNGS

V.L. Sokolovsky, G.B. Furman, D.A. Polyanskaya, E.G. Furman SPATIO-TEMPORAL MODELING OF COVID-19 EPIDEMIC

\section{RISK ASSESSMENT IN HYGIENE}

S.M. Kiselev, N.K. Shandala, T.N. Lashchenova, Yu.N. Zozul, V.V. Shlygin, T.I. Gimadova, A.N. Malakhova HEALTH RISK ANALYSIS AS PER RADIATION AND CHEMICAL FACTORS IN A ZONE INFLUENCED BY A NUCLEAR LEGACY OBJECT

N.V. Zaitseva, M.A. Zemlyanova, Yu.V. Koldibekova, N.I. Bulatova OMIC MARKERS IDENTIFICATION FOR PREDICTING RISKS OF NEGATIVE EFFECTS IN CHILDREN WITH ELEVATED COPPER AND NICKEL CONTENTS IN BLOOD

O.G. Bogdanova, O.A. Molchanova, I.Yu. Tarmaeva, N.V. Efimova ASSESSMENT AND CLASSIFICATION OF FOOD PRODUCTS AS PER HEALTH RISKS CAUSED BY CHEMICAL AND MICROBIOLOGICAL CONTAMINATION

A. Feseha, A.K. Chaubey, A. Abraha HEAVY METAL CONCENTRATION IN VEGETABLES AND THEIR POTENTIAL RISK FOR HUMAN HEALTH

P.Z. Shur, N.V. Zaitseva, V.A. Fokin, D.A. Kiryanov, A.A. Khasanova METHODICAL APPROACHES TO ASSESSING INDIVIDUAL OCCUPAITONL HEALTH RISK CAUSED BY WORK-RELATED DISEASES DURING THE WHOLE EMPLOYMENT PERIOD

I.V. Bukhtiyarov, O.I. Yushkova, M. Khodzhiev, A.V. Kapustina, A.Yu. Forverts PHYSIOLOGICAL CRITERIA FOR IMPROVING LABOR INTENSITY CLASSIFICATION USED IN OCCUPATIONAL RISKS ASSESSMENT

Kurnia Ardiansyah Akbar HYPERTENSION AMONG COAL MINING WORKERS ASSOCIATED WITH PARENTAL HYPERTENSION IN INDONESIA

\section{ПРОФИЛАКТИЧЕСКАЯ МЕДИЦИНА: АКТУАЛЬНЫЕ АСПЕКТЫ АНАЛИЗА РИСКА ЗДОРОВЬЮ}

4 А.Ю. Попова, С.В. Кузьмин, Н.В. Зайцева, И.В. Май ПРИОРИТЕТЫ НАУЧНОЙ ПОДДЕРЖКИ ДЕЯТЕЛЬНОСТИ САНИТАРНОЭПИДЕМИОЛОГИЧЕСКОЙ СЛУЖБЫ В ОБЛАСТИ ГИГИЕНЫ: ПОИСК ОТВЕТОВ НА ИЗВЕСТНЫЕ УГРОЗЫ И НОВЫЕ ВЫЗОВЫ

15 Н.Е. Пиль, В.М. Чигвинцев ЧИСЛЕННОЕ МОДЕЛИРОВАНИЕ ЭВОЛЮЦИИ БАКТЕРИАЛЬНОЙ ПОПУЛЯЦИИ В ЛЕГКИХ ЧЕЛОВЕКА

23 В.Л. Соколовский, Г.Б. Фурман, Д.А. Полянская, Е.Г. Фурман ПРОСТРАНСТВЕННО-ВРЕМЕННОЕ МОДЕЛИРОВАНИЕ ЭПИДЕМИИ COVID-19

\section{ОЦЕНКА РИСКА В ГИГИЕНЕ}

38 С.М. Киселев, Н.К. Шандала, Т.Н. Лащенова, Ю.Н. Зозуль, В.В. Шльгин, Т.И. Гимадова, А.Н. Малахова АНАЛИЗ РИСКА ДЛЯ ЗДОРОВЬЯ НАСЕЛЕНИЯ ПРИ ВОЗДЕЙСТВИИ РАДИАЦИОННЫХ И ХИМИЧЕСКИХ ФАКТОРОВ В РАЙОНЕ РАСПОЛОЖЕНИЯ ОБЪЕКТА ЯДЕРНОГО НАСЛЕДИЯ

48 Н.В. Зайцева, М.А. Землянова, Ю.В. Кольдибекова, Н.И. Булатова ВЫЯВЛЕНИЕ ОМИК-МАРКЕРОВ ДЛЯ ПРОГНОЗИРОВАНИЯ РИСКА РАЗВИТИЯ НЕГАТИВНЫХ ЭФФЕКТОВ У ДЕТЕЙ С ПОВЫШЕННЫМ СОДЕРЖАНИЕМ МЕДИ И НИКЕЛЯ В КРОВИ

57 О.Г. Богданова, О.А. Молчанова, И.Ю. Тармаева, Н.В. Ефимова ОЦЕНКА И КЛАССИФИКАЦИЯ ПИЩЕВОЙ ПРОДУКЦИИ ПО УРОВНЮ РИСКА ДЛЯ ЗДОРОВЬЯ, СВЯЗАННОГО С ХИМИЧЕСКОЙ И МИКРОБИОЛОГИЧЕСКОЙ КОНТАМИНАЦИЕЙ

68 А. Фесеха, А.К. Чаубей, А. Абраха КОНЦЕНТРАЦИЯ ТЯЖЕЛЫХ МЕТАЛЛОВ В ОВОЩАХ С ИРРИГАЦИОННЫХ ПОЛЕЙ, ИСПОЛЬЗУЮЩИХ СТОЧНЫЕ ВОДЫ, И ПОТЕНЦИАЛЬНЫЙ РИСК ЗДОРОВЬЮ НАСЕЛЕНИЯ

82 П.З. Шур, Н.В. Зайцева, В.А. Фокин,

Д.А. Кирьянов, А.А. Хасанова МЕТОДИЧЕСКИЕ ПОДХОДЫ К ОЦЕНКЕ ПЕРСОНАЛЬНОГО ПРОФЕССИОНАЛЬНОГО РИСКА ЗДОРОВЬЮ, ОБУСЛОВЛЕННОГО БОЛЕЗНЯМИ, СВЯЗАННЫМИ С РАБОТОЙ, НА ПРОТЯЖЕНИИ ВСЕГО ПЕРИОДА ТРУДОВОЙ ДЕЯТЕЛЬНОСТИ

90 И.В. Бухтияров, О.И. Юикова, М. Ходжиев, А.В. Капустина, А.Ю. Форвери ФИЗИОЛОГИЧЕСКИЕ КРИТЕРИИ В СОВЕРШЕНСТВОВАНИИ КЛАССИФИКАЦИИ НАПРЯЖЕННОСТИ ТРУДА ДЛЯ ЗАДАЧ ОЦЕНКИ ПРОФЕССИОНАЛЬНОГО РИСКА

100 Курния Ардиансьях Акбар ГИПЕРТОНИЯ УГОЛЬНЫХ РАБОЧИХ В ИНДОНЕЗИИ, СВЯЗАННАЯ С РОДИТЕЛЬСКОЙ ГИПЕРТЕНЗИЕЙ 


\section{HEALTH RISK ANALYSIS IN EPIDEMIOLOGY}

S.A. Iglovsky, V.V. Kriauciunas ANTHRAX CATTLE BURIALS AS A POTENTIAL THREAT CAUSED BY CHANGES IN CRYOLITE ZONES IN THE NORTHERN EUROPEAN PART OF RUSSIA

B.A. Revich, D.A. Shaposhnikov, S.R. Raichich, S.A. Saburova, E.G. Simonova

CREATING ZONES IN ADMINISTRATIVE DISTRICTS LOCATED IN THE RUSSIAN ARCTIC REGION SPECIFIC AS PER THREATS OF CATTLE BURIALS DECAY DUE TO PERMAFROST DEGRADATION

MEDICAL AND BIOLOGICAL ASPECTS RELATED TO ASSESSMENT OF IMPACTS EXERTED BY RISK FACTORS

Yu.I. Chernyak ASSOCIATION BETWEEN HSPA1B, S100B, AND TNF- $\alpha$ GENE POLYMORPHISMS AND RISKS OF CHRONIC MERCURY POISONING

A.V. Shabaldin, A.V. Tsepokina, O.V. Dolgikh, E.V. Shabaldina, A.V. Ponasenko COMBINATION OF HLA-DRB1 ALLELES AS A FACTOR CAUSING RISKS OF SPORADIC CONGENITAL HEART DEFECTS AND CONGENITAL MALFORMATIONS WITHOUT CHROMOSOME DISEASES

RISK ASSESSMENT IN PUBLIC HEALTHCARE

O.V. Mitrokhin, N.A. Ermakova, E.V. Belova THEORETICAL GROUNDS FOR ASSESSING HEALTH RISKS FACTORS CAUSED BY SELF-ISOLATION

E.A. Shashina, T.S. Isiutina-Fedotkova, V.V. Makarova, O.A. Gruzdeva, O.V. Mitrokhin APPROACHES TO ANALYZING EFFICIENCY OF RESPIRATORY PROTECTIVE EQUIPMENT AS A WAY TO REDUCE HEALTH RISKS DURING COVID-19 PANDEMIC

ANALYTICAL REVIEWS

P.Yu. Petrova, A.D. Aga, E.S. Trapeznikova, E.V. Budanova GUT MICROBIOTA AS RISK FACTOR CAUSING OBESITY IN CHILDREN

V.A. Loginova, Yu.N. Kas'kov, E.A. Zhidkova, K.G. Gurevich, Yu.L. Smertina, O.A. Pletnikova REGULATION OF WORK-RELATED AND OCCUPATIONAL IMPACTS ON WORKERS EMPLOYED AT RAILROADS: EXPERIENCE GAINED IN RUSSIA AND OTHER COUNTRIES

V.F. Spirin, A.M. Starshov

ON CERTAIN ISSUES RELATED TO CHRONIC EXPOSURE TO OCCUPATIONAL NOISE AND IMPACTS EXERTED BY IT ON WORKERS' BODIES (LITERATURE REVIEW)

\section{ОЦЕНКА РИСКА В ЭПИДЕМИОЛОГИИ}

108 С.А. Игловский, В.В. Кряучюнас СИБИРЕЯЗВЕННЫЕ ЗАХОРОНЕНИЯ ПОТЕНЦИАЛЬНАЯ УГРОЗА ПРИ ИЗМЕНЕНИИ КРИОЛИТОЗОНЫ ЕВРОПЕЙСКОГО СЕВЕРА РОССИИ

115 Б.А. Ревич, Д.А. Шапошников, С.Р. Раичич, С.А. Сабурова, Е.Г. Симонова ЗОНИРОВАНИЕ АДМИНИСТРАТИВНЫХ РАЙОНОВ РОССИЙСКОЙ АРКТИКИ ПО СТЕПЕНИ ОПАСНОСТИ РАЗРУШЕНИЯ СКОТОМОГИЛЬНИКОВ В РЕЗУЛЬТАТЕ ДЕГРАДАЦИИ МНОГОЛЕТНЕЙ МЕРЗЛОТЫ

\section{МЕДИКО-БИОЛОГИЧЕСКИЕ АСПЕКТЫ} ОЦЕНКИ ВОЗДЕЙСТВИЯ ФАКТОРОВ РИСКА

126 Ю.И. Черняк

АССОЦИАЦИЯ ПОЛИМОРФИЗМОВ HSPA1B, S100B И ТNF- $\alpha$ ГЕНОВ С РИСКОМ РАЗВИТИЯ ХРОНИЧЕСКОЙ РТУТНОЙ ИНТОКСИКАЦИИ

133 А.В. Шабалдин, А.В. Цепокина, О.В. Долгих, Е.В. Шабалдина, А.В. Понасенко СОЧЕТАНИЕ АЛЛЕЛЕЙ НLА-DRВ1 КАК УСЛОВИЕ РЕАЛИЗАЦИИ РИСКА ФОРМИРОВАНИЯ СПОРАДИЧЕСКИХ ВРОЖДЕННЫХ ПОРОКОВ СЕРДЦА И ВРОЖДЕННЫХ ПОРОКОВ РАЗВИТИЯ ПЛОДА БЕЗ ХРОМОСОМНЫХ ЗАБОЛЕВАНИЙ

\section{ОЦЕНКА РИСКА В ОРГАНИЗАЦИИ ЗДРАВООХРАНЕНИЯ}

143 О.В. Митрохин, Н.А. Ермакова, Е.В. Белова ТЕОРЕТИЧЕСКОЕ ОБОСНОВАНИЕ ОЦЕНКИ ФАКТОРОВ РИСКА ЗДОРОВЬЮ В УСЛОВИЯХ САМОИЗОЛЯЦИИ

151 Е.А. Шашина, Т.С. Исютина-Федоткова, В.В. Макарова, О.А. Груздева, О.В. Митрохин ПОДХОДЫ К АНАЛИЗУ ЭФФЕКТИВНОСТИ СРЕДСТВ ЗАЩИТЫ ОРГАНОВ ДЫХАНИЯ КАК МЕР СНИЖЕНИЯ РИСКА НАРУШЕНИЯ ЗДОРОВЬЯ ВО ВРЕМЯ ПАНДЕМИИ COVID-19

\section{АНАЛИТИЧЕСКИЕ ОБЗОРЫ}

159 П.Ю. Петрова, А.Д. Ага, Е.С. Трапезникова, Е.В. Буданова СОСТАВ КИШЕЧНОЙ МИКРОБИОТЫ КАК ФАКТОР РИСКА РАЗВИТИЯ ОЖИРЕНИЯ У ДЕТЕЙ

173 В.А. Логинова, Ю.Н. Каськов, Е.А. Жидкова, К.Г. Гуревич, Ю.Л. Смертина, О.А. Плетникова РЕГУЛИРОВАНИЕ ПРОФЕССИОНАЛЬНОАССОЦИИРОВАННЫХ ПРОИЗВОДСТВЕННЫХ ВОЗДЕЙСТВИЙ НА РАБОТНИКОВ ЖЕЛЕЗНОДОРОЖНОГО ТРАНСПОРТА: ОПЫТ РОССИИ И ДРУГИХ СТРАН

185 В.Ф. Спирин, А.М. Стариов К НЕКОТОРЫМ ПРОБЛЕМАМ ХРОНИЧЕСКОГО ВОЗДЕЙСТВИЯ ПРОИЗВОДСТВЕННОГО ШУМА НА ОРГАНИЗМ РАБОТАЮЩИХ (ОБЗОР ЛИТЕРАТУРЫ) 
PREVENTIVE HEALTHCARE:

TOPICAL ISSUES OF HEALTH RISK ANALYSIS

UDC $001.89 ; 613$

DOI: $10.21668 /$ health.risk/2021.1.01.eng

Read

online

Research article

\title{
PRIORITIES IN SCIENTIFIC SUPPORT PROVIDED FOR HYGIENIC ACTIVITIES ACCOMPLISHED BY A SANITARY AND EPIDEMIOLOGIC SERVICE: HOW TO FACE KNOWN THREATS AND NEW CHNALLANGES
}

\author{
A.Yu. Popova ${ }^{1,2}$, S.V. Kuzmin ${ }^{3}$, N.V. Zaitseva ${ }^{4}$, I.V. May ${ }^{4}$ \\ ${ }^{1}$ Federal Service for Surveillance on Consumer Rights Protection and Human Wellbeing, Bldg. 5 and 7 , \\ 18 Vadkovskiy lane, Moscow, 127994, Russian Federation \\ ${ }^{2}$ Russian Medical Academy for Postgraduate Studies, 2/1 Barrikadnaya Str., Moscow, 123995, Russian Federation \\ ${ }^{3}$ Federal Research Center of Hygiene named after F.F. Erisman, 2 Semashko Str., Mytishchi, 141014, \\ Russian Federation \\ ${ }^{4}$ Federal Scientific Center for Medical and Preventive Health Risk Management Technologies, 82 Monastyrskaya \\ Str., Perm, 614045, Russian Federation
}

Scientific support provided for activities accomplished by the Federal Service for Surveillance over Consumer Rights Protection and Human Well-being is considered to be a most significant tool for raising productivity and efficiency of the system functioning. A concept on scientific support provided for Rospotrebnadzor's organs and authorities in 2021-2025 focuses on creating an integral, coordinated, efficient, stable, and adaptive system of scientific support provided for activities aimed at securing sanitary-epidemiologic welfare of the population. A peculiar feature of this concept for 2021-2025 is an emphasis on science-intensive analysis technologies and predictions based on digital informational and analytical support provided for strategic and operative decisions on minimizing risks and damage to population health. Another emphasis is on significance of fundamental hygienic research. The concept sets the tasks to develop scientific grounds for cellular and sub-cellular technologies applied to diagnose health disorders under exposure to occupational and environmental factors as well as lifestyle-related ones. It is necessary to create a personified medical and preventive platform for preserving life and health; the platform should be based on risk assessing, monitoring and prediction, mathematical modeling of processes occurring in a body, and the latest data on physiology and toxicology. The Concept also covers issues related to developing innovative technologies for preventing and rehabilitating diseases associated with environmental and occupational factors basing on science-intensive cross-disciplinary studies and the most up-to-date hardware and software complexes. More enhanced hygienic and epidemiologic research is an extremely important and promising vector in scientific development. The Concept outlines the necessity to promptly make new technologies available to experts who are responsible for control, surveillance, inspections, licensing, and other activities within Rospotrebnadzor system.

The Concept on scientific support is being implemented via «Scientific substantiation for the national system for providing sanitary-epidemiologic welfare, health risk management, and raising life quality of the RF population», a specialized scientific-research program for 2021-2025. More than $80 \%$ resources allocated within the specialized program will be assigned for solving the most vital tasks and preventing future threats. Finding solutions to major strategic tasks set by the Concept and the specialized scientific program will allow achieving greater contributions made by organs and authorities of the sanitary-epidemiologic service into scientific, technological, and socioeconomic development of the country including a contribution into developing and implementing competitive scientific-technical products. program.

Key words: Rospotrebnadzor, hygienic studies, scientific support, concept on scientific support, specialized scientific

(c) Popova A.Yu., Kuzmin S.V., Zaitseva N.V., May I.V., 2021

Anna Yu. Popova - Doctor of Medical Sciences, Professor, Supervisor, Head of the Department for Sanitary-Epidemiologic Service Organization (e-mail: rmapo@rmapo.ru; tel.: +7 (499) 458-95-63; ORCID: https://orcid.org/0000-0002-4315-5307).

Sergey V. Kuzmin - Doctor of Medical Sciences, Professor, Director (e-mail: kuzminsv@fferisman.ru; tel.: +7 (495) 586-11-44; ORCID: http://orcid.org/0000-0002-9119-7974).

Nina V. Zaitseva - Academician of the Russian Academy of Sciences, Doctor of Medical Sciences, Professor, Scientific Director (e-mail: znv@ffcrisk.ru; tel.: +7 (342) 237-25-34; ORCID: https://orcid.org/0000-0003-2356-1145).

Irina V. May - Doctor of Biological Sciences, Professor, Deputy Director responsible for research work (e-mail: may@fcrisk.ru; tel.: +7 (342) 237-25-47; ORCID: https://orcid.org/0000-0003-0976-7016). 
At present scientific and technologic development is becoming more and more rapid, competition is getting stronger, and geopolitical factors tend to exert greater influence on the society thus bringing about new global challenges; all this requires developing and implementing new conceptual decisionmaking models as regards strategies for economic and social development. Fundamental factors of the global crisis that started in 2009 (economic instability, loss of more than 5 million workplaces in the leading world economies [1]; growing gap between developed and developing countries [2]) have been aggravated with epidemiological problems. Thus, the agenda of the World Economic Forum in Davos in 2021 was given with a slogan «The Great Reload in an epoch after COVID-19 pandemic» even in October last year. «New normality» concept that came to life when the crisis had just begun has become wider used $[3,4]$; it means that it is impossible to return to values and levels of the past; a change of paradigms, both regarding public and individual behavior; and occurrence or changes in risks for human life, health, and well-being $[5,6]$.

The existing situation requires serious changes in former approaches, most of all, when it comes to preserving human capital and achieving a considerable growth in it. Most states, Russia included, are well aware of it: «Each our new step, each new law, or a state program should be assessed, first of all, bearing in mind the top national priority which is preserving the country population and achieving considerable population growth» (as it was stated by the RF President in his Message to the Federal Assembly of the Russian Federation issued on January 21,2020$)^{1}$.

In countries that are planning to invest into «health-oriented» projects new conceptual approaches are being developed to implementing «reasonable regional strategies»; innovative and high-tech clusters and Centers of Ex- cellence are being created; development funds for priority technological, social, and ecological projects are being organized. A greater attention is being paid to increasing intensity and efficiency of cooperation between academician centers, centers at higher educational establishments, departmental centers and business; the focus is also on developing the most competent and authoritative scientific schools, on creating new technological platforms, and making decisions basing on reaching a consensus between all the stakeholders. Maximum support is being provided for development of high-tech services that are competitive at the global markets [6-8].

Threats and challenges related to hygienic safety are not so obvious and are not being discussed as vividly as ones related to biological (epidemiologic) safety. It is especially true in the current situation when the whole world is concentrating on issues related to COVID-19 pandemic. But it certainly doesn't mean that hygienic issues are becoming less significant in terms of their ability to cause medical and demographic losses [9-12].

Ambient air contamination, especially in large and medium-sized industrial centers, causes health risks including carcinogenic ones. In some cases these risks are assessed as intolerable and they result in additional deaths, respiratory diseases, diseases if the circulatory system, oncologic diseases, diseases of the immune and endocrine system etc. In Russia poor ambient air quality annually causes proximately 3,000 deaths and more than 800 thousand diseases cases ${ }^{2}$ [13-15].

It is still not prohibited by legislation to discharge contaminated sewage into water objects including those used as sources for communal and drinking water supply. Considerable efforts made by the state authorities aiming at providing people with high quality drinking water have yielded some positive results as there has been almost a $20 \%$ decrease

\footnotetext{
${ }^{1}$ The RF President Message to the Federal Assembly of the Russian Federation issued on January 21, 2020. Parlamentskaya gazeta (The Parliament bulletin). Available at: https://www.pnp.ru/politics/opublikovan-polnyy-tekst-poslaniyaprezidenta-federalnomu-sobraniyu.html (02.02.2021) (in Russian).

${ }^{2}$ On sanitary-epidemiologic welfare of the population in the Russian Federation in 2019. The state report. Moscow, The Federal Service for Surveillance over Consumer Rights Protection and Human Well-being, 2020, 299 p. (in Russian).
} 
in a share of drinking water samples taken from centralized water supply systems that deviated from hygienic standards. But still, approximately $8 \%$ people living in the country are not provided with drinking water that has proper quality and is truly safe [16, 17].

Accumulated industrial and consumer wastes (approximately 31.6 billion tons) are deposited on a territory with its total square being approximately equal to 4.0 million hectares. Since such damping grounds are usually located close to residential areas, they deteriorate quality of the environment and often cause social confrontations. Contamination of underground water sources and soils including agricultural ones is often registered in many RF regions; sanitary standards and requirements to agricultural products as food raw materials are also violated rather frequently [18-20].

There are still issues related to persistent noise exposure on urban territories including zones influenced by airfields and airports [21]. Health risks caused by exposure to physical factors require precise quantitative assessment and preventive activities.

Pesticides and agricultural chemicals are being produced in larger quantities, their range is growing as new products are being introduced on a market and implemented into everyday practice; the same goes for nanoparticles and nanomaterials as new substances and materials are being synthesized and distributed in such industries as chemistry and petrochemistry, pharmaceutics, construction and finishing materials manufacture, agriculture, etc. All this leads to a considerable growth in a range of chemicals that people have to contact. Overall, approximately 89.1 million people $(62.6 \%$ of the country population) live under exposure to complex chemical burden determined by contaminated food products, drinking water, ambient air, and soils [22, 23]. It requires wide-scale advanced toxicological and hygienic studies including those accomplished with the best available laboratory instruments and procedures.

Workers' health preservation and improvement is still a pressing issue, especially given a steady rise in retirement age [24].
Education and lifestyle of the rising generation should not be neglected. These issues have always been paid special attention to by the sanitary authorities; however, given fundamentally new approaches to organizing the educational process for children, namely, digital technologies being applied during lessons, changes in the structure of educational activities, less frequent and less intensive physical activity, etc., it is necessary to develop innovative approaches to managing health risks for children since their health deteriorates due to all the above-mentioned changes in the educational process $[25,26]$.

We should also mention that the existing sanitary-hygienic situation is developing under influence exerted by climatic changes that create not only economic and epidemiologic risks but also sanitary-hygienic ones. Permafrost thawing in the Arctic regions imposes a threat that an emergency can occur at industrial objects with such adverse consequences as ambient air, soils, and water objects being contaminated with chemicals including extremely hazardous ones. In dry arid regions climatic changes aggravate problems related to agricultural and drinking water supply with all negative outcomes including medical and demographic ones [27, 28].

Influence exerted by all the above mentioned negative trends on population health which is associated with risks in the sphere of sanitary-epidemiologic welfare of the RF population cannot be properly assessed without technical support provided for the overall decision-making and practical actions.

Obviously, the current activities performed by Rospotrebnadzor are provided with the upto-date scientific instruments and procedures which mostly correspond to the best available world practices.

Today research and development in the sphere of providing sanitary-epidemiologic welfare for the population is accomplished by 28 scientific organizations within Rospotrebnadzor structure. Approximately 5,000 people are employed by these scientific organizations including 11 RAS academicians and corresponding members, 380 Doctors of Sciences, and more than 1,200 Candidates of Sciences. 
Laboratory support provided for social and hygienic monitoring and control activities includes up-to-date technological base that allows performing gas and high-performance liquid chromatography, atomic-absorption analysis, mass spectrometry with inductively coupled plasma, etc. Existing procedures for measuring admixtures in ambient air, air inside buildings, drinking water, soils, and food products, allow performing control over them in their reference concentrations that guarantee safety of the environment for people. Biological monitoring is also being developed at the moment [29-31].

Science-intense procedures for analyzing sanitary-epidemiologic situation often involve using the latest geoinformation systems together with the up-to-date mathematical instruments (fuzzy sets theory, neural networks, situation modeling, etc.); it provides an opportunity to perform spatiotemporal analysis of how risks and damage to health are distributed and develop in dynamics [32, 33].

Cellular and sub-cellular technologies, including proteome and metabolome analysis, are used to assess sanitary-hygienic situation and create an evidence base to prove negative effects produced by environmental factors on human health. They allow obtaining exposure «traces» that reflect a metabolic state of a body and getting an insight into pathogenesis of health disorders under exposure to certain substances or agents [34].

Scientific approaches to creating a riskoriented model of control and surveillance activities performed by Rospotrebnadzor allowed simultaneous reduction in overall number of inspections and stricter control over objects that created major risks and threats for population health.

Scientific support is considered the most significant tool for raising efficiency and productivity of the overall sanitary-epidemiologic service functioning; given that, a work group has developed «The Concept of scientific support provided for Rospotrebnadzor organs and authorities in 2021-2025 and brunch programs on topical issues related to provision of Rospotrebnadzor activities» which was approved by the Head of the Service on December 21, 2020 No. 869 (hereinafter called the Concept).

The document was developed taking into account basic provisions and targets fixed by the strategic documents issued in the RF, including those related to modern science development. These documents include «The Strategy for medical science development in the Russian Federation up to 2025 (approved on by the RF Government Order issued on December 28, 2012 No. 2580-r)» ${ }^{3}$; «The Strategy for scientific and technological development in the Russian Federation» (approved by the RF President Order on December 01, 2016 No. 642) ${ }^{4}$; The RF President Message to the RF Federal Assembly on March 01, 2018 «On national goals and strategic tasks in the RF development for a period up to 2024»; The RF President Order dated May 07, 2018 No. $204^{6}$ «The basics of the state policy in the sphere of providing chemical and biological safety in the Russian Federation up to 2025 and further on» (approved by the RF President Order dated March 11, 2019 No. 97) ${ }^{7}$; The RF President Order dated June 06, 2019 No. 254 «On the

\footnotetext{
${ }^{3}$ The Strategy for medical science development in the Russian Federation up to 2025: The RF Government Order issued on December 28, 2012 No. 2580-r. KonsultantPlus. Available at: http://www.consultant.ru/document/cons_doc_LAW_140249/ (02.02.2021) (in Russian).

${ }^{4}$ The Strategy for scientific and technological development in the Russian Federation: The RF President Order issued on December 01, 2016 No. 642 (last edited on March 15, 2021). KonsultantPlus. Available at: http://www.consultant.ru/document/cons doc LAW 207967/ (02.02.2021) (in Russian).

${ }^{5}$ The $R \bar{F}$ President Message to the RF Federal Assembly on March 01, 2018. KonsultantPlus. Available at: http://www.consultant.ru/document/cons_doc_LAW_291976/ (02.02.2021) (in Russian).

${ }^{6}$ On national goals and strategic tasks in the $\bar{R} F$ development for a period up to 2024 The RF President Order dated May 07, 2018 No. 204. The official Internet-portal for legal information. Available at: http://www.consultant.ru/document/cons_doc_LAW_291976/(02.02.2021) (in Russian).

${ }^{7}$ The basics of the state policy in the sphere of providing chemical and biological safety in the Russian Federation up to 2025 and further on: The RF President Order dated March 11, 2019 No. 97. KonsultantPlus. Available at: http://www.consultant.ru/document/cons_doc_LAW_319787/(02.02.2021) (in Russian).
} 
strategy for the public healthcare development in the Russian Federation up to $2025 »^{8}$; «Basics of the state policy in the sphere of providing nuclear and radiation safety in the Russian Federation up to 2025 and further on» (approved by the RF President Order dated October 13, 2018 No. 585) ${ }^{9}$.

Primary goals set by the Concept include progressive development of specialized science aimed at creating integral, coordinated, efficient, stable, and adaptive system of scientific support provided for activities aimed at securing sanitary-epidemiologic welfare of the population.

Priorities for scientific research in the sphere of hygiene, population health improvement, and sanitary surveillance development have been determined in full conformity with the functions the Service performs and powers it possesses and taking into account challenges and threats, both existing and predicted ones (for a short-term and middle-term periods). These priorities include the following:

- substantiating procedures for systemic assessing, predicting, and managing health risks and life quality related to environmental factors;

- giving scientific grounds for complex measures aimed at assessing and managing health risks for employable population in leading industrial and agricultural branches;

- developing procedures for systemic assessment, predicting, and managing health risks for children, teenagers, and young people related to environmental factors, peculiarities of their activities and life style;

- giving scientific grounds for risks management and assessment aimed at providing food safety;

- developing scientific grounds for a digital and medical-preventive platform for health improvement on the basis of population and individual risks prediction and assessment of damage to health associated with environmental factors and life quality;

- developing procedures for hygienic standardization and control basing on international data, mathematic modeling and health risk assessment methodology;

- scientific support for providing radiation safety in Russia in order to minimize health risks.

Each priority is given vital tasks and subjects for scientific research, for example:

- developing new procedures for identification and quantitative assessment of environmental factors including screening and biological monitoring;

- developing methodical grounds for assessing and predicting influence exerted by various factors on health of people from different population groups using chemical, clinical, functional, immunologic, genetic, cytological, non-invasive, and alternative procedures;

- determining cause and effect relations and their parameters in development of work-related and occupational morbidity and developing a scientifically grounded risk management system for employable population's health;

- giving scientific grounds for minimizing risks for children and teenagers health given specific conditions of the modern educational process;

- developing toxicological procedures for assessing xenobiotics, new substances and materials, including nano-sized ones, basing on examining overall toxic and specific effects (mutagenic, carcinogenic, gonadotoxic, embryotoxic, teratogenic, neurotoxic ones, etc.);

- developing theory and practice of hygienic standardization taking into account the latest scientific advances in medicine and biology, including those achieved at cellular, genetic, and molecular levels;

- updating state safety regulations when ionizing irradiation sources are used taking

\footnotetext{
${ }^{8}$ On the strategy for the public healthcare development in the Russian Federation up to 2025: The RF President Order dated June 06, 2019 No. 254. KonsultantPlus. Available at: http://www.consultant.ru/document/cons_doc_LAW_326419/ (02.02.2021) (in Russian).

${ }^{9}$ Basics of the state policy in the sphere of providing nuclear and radiation safety in the Russian Federation up to 2025 and further on: The RF President Order dated October 13, 2018 No. 585. KonsultantPlus. Available at: http:// www.consultant.ru/document/cons_doc_LAW_308884/(02.02.2021) (in Russian).
} 
into account the latest technical, scientific, and industrial developments;

- examining mechanisms of health disorders occurrence and development under exposure to a set of factors (genetic, natural-climatic, technogenic, biological, environmental, occupational, related to life style, etc.) using scienceintense diagnostic and information platforms;

- developing etiologic and pathogenetic grounds for preventing non-communicable diseases associated with risk factors; developing scientific grounds for a personified medical and preventive platform for life and health preservation based on risk assessment, monitoring, and prediction, etc.

A peculiar feature of this Concept for 2021-2025 is an emphasis on science-intensive analysis technologies and predictions based on digital informational and analytical support provided for strategic and operative decisions on minimizing risks and damage to population health. The Concept stipulates that it is necessary to develop algorithms and procedures for data collection and processing, scenario modeling, building up intellectual hard- and software complexes; these complexes should have a capacity to generate new conclusions that might not always be obvious even for experts and they should be capable to do it basing on analyzing multi-dimensional and variable data sometimes even in on-line mode.

The provisions fixed in the Concept fully correspond to goals and tasks set within the Program for fundamental scientific research in the Russian Federation for a long-term period (2021-2030) that was approved on December 31, 2020 by the RF Government Order No. 3684- ${ }^{10}$, Rospotrebnadzor being an involved performer.

The departmental document (The Concept) highlights the necessity to provide support for fundamental hygienic research that in future can give a new impulse to applied studies with significant practical results. It sets the tasks to develop scientific grounds for identifying and monitoring over proteomic profiles, expression, and polymorphism of certain genes and ultrastructural disorders in a body occurring under exposure to occupational and environmental factors and factors related to life-style. It is also necessary to create a personified medical and preventive platform for life and health preservation basing on risks assessment, monitoring, and prediction, mathematic modeling of processes occurring in a human body, and the latest data on physiology and toxicology. The Concept also fixes the tasks to develop innovative technologies for preventing and rehabilitating diseases associated with environmental and occupational factors basing on science-intensive cross-disciplinary studies and the most up-todate hardware and software complexes. A lot of studies concentrate on managing risks for children's and teenagers' health given implementation of new information technologies and significant changes in behavioral patterns and lifestyle.

More enhanced hygienic and epidemiologic research is an extremely important and promising vector in scientific development. First of all, in comes to scientific developments that focus on examining mechanisms and consequences of effects produced by environmental contamination on post-vaccination immunity formation and support and on an epidemiologic process itself. Such borderline studies are especially vital both in the existing sanitary-epidemiologic situation and taking into account similar threats and risks that might occur in future [35-39].

But still it is obvious that scientific research should satisfy practical needs of Rospotrebnadzor. It requires making new technologies instantly available to experts who are responsible for control, surveillance, inspections, licensing, and other activities within Rospotrebnadzor system. The latter requires certain efforts made not only by scientific organizations but also workers from practical sections in the Service who should master new competences and skills (Figure).

\footnotetext{
${ }^{10}$ On Approval of Program for fundamental scientific research in the Russian Federation for a long-term period (20212030): The RF Government Order issued on December 31, 2020 No. 3684-r On Approval of Program for fundamental scientific research in the Russian Federation for a long-term period (2021-2030). Garant.Ru. Information and legal portal. Available at: http://www.garant.ru/products/ipo/prime/doc/400070256/(02.02.2021) (in Russian).
} 


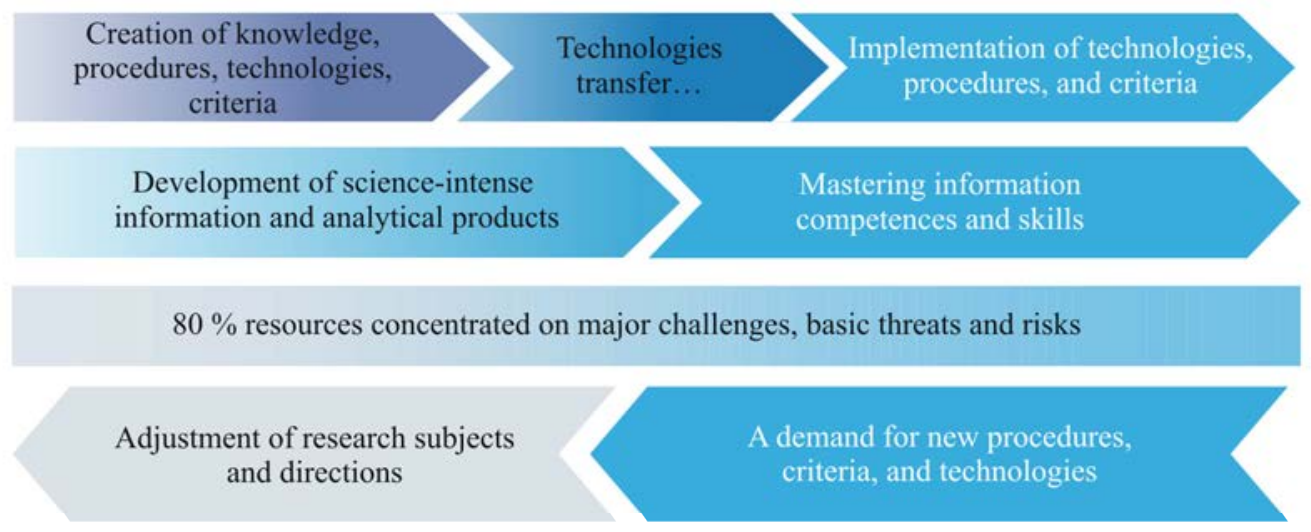

Figure. A conceptual scheme showing interaction between theory and practice given new challenges and threats

In its turn, mastering new procedures and techniques that involve work with information flows and analysis results will allow experts employed by Rospotrebnadzor authorities and centers for hygiene and epidemiology to provide proper feedback, when new tasks are set forth for scientists as per results obtained via control and surveillance activities and social and hygienic monitoring and a demand occurs for new technologies, procedures, criteria, etc.

The Concept on scientific support is being implemented via a specialized scientific and research program for 2021-2025 called «Scientific substantiation for the national system for providing sanitary-epidemiologic welfare, health risk management, and raising life quality of the RF population». The Program contains a list of 169 scientific research works that should allow solving 26 major tasks in 7 scientific schools in the sphere of hygiene. 143 research works have been inspected by the RAS and included into state tasks formulated for departmental scientific research that should be performed by relevant scientific organizations in 2021.

The specialized program is assumed to assign more than $80 \%$ of all its resources for solving the most vital tasks and preventing future threats. Some scientific organizations within Rospotrebnadzor system will have to change directions and contents of their scientific research.

The specialized program is also assumed to simultaneously preserve basic research vectors but also be dynamic to a certain extent as it will provide an opportunity to adjust certain scientific research as a response to occurring vital tasks and challenges. Besides, the program will be able to react to any changes in provisions fixed in strategic documents such as «Ecology», «Demography», and «Public healthcare» National projects, the RF Government Order No. 3680-r issued on December 20, $2020^{11}$, «The activity program («roadmap») on developing and enhancing the system of federal state sanitary-epidemiologic surveillance for 2021-2028», «The activity plan within the Childhood Decade for a period up to 2027》 (approved by the RF Government Order on January 23, 2021 No. 122-r) ${ }^{12}$ etc.

Research works being accomplished at present and planned for the future are diverse; their subjects are also diverse and there are different programs that cover them. It also involves a necessity to solve a great number of tasks and engage a lot of experts as well as to generalize and integrate all the obtained results; sanitary-epidemiologic legislation is to be up-

\footnotetext{
${ }^{11}$ On Approval of The activity program («roadmap») on developing and enhancing the system of federal state sanitaryepidemiologic surveillance for 2021-2028: The RF Government Order issued on December 20, 2020 No. 3680-r. KonsultantPlus. Available at: http://www.consultant.ru/document/cons_doc_LAW_373356/(02.02.2021) (in Russian).

${ }^{12}$ On Approval of «The activity plan within the Childhood Decade for a period up to 2027»: The RF Government Order issued on January 23, 2021 No. 122-r. KonsultantPlus. Available at: http://www.consultant.ru/document/cons_doc_LAW_373356/(02.02.2021) (in Russian).
} 
dated and it will require drawing up diverse regulatory and methodical documents. Given all that, it is obvious that close contacts between scientific organizations and practical divisions of the Service call for new approaches to organizing scientific research and implementation of project management instruments.

A plan is to raise efficiency of immediate and long-term planning and coordination between scientific research and development activities via taking into account all obtained scientific results and their implementation into practice. The Concept envisages development of monitoring activities and procedures for assessing efficiency and productivity of researchers, divisions, and work teams as a whole; new activities aimed at raising scientific research to new levels are to be developed and implemented.

Interaction between scientific organizations within Rospotrebnadzor system and territorial bodies, including other federal executive authorities, is to be enhanced. An important tool in this interaction is creation of reference centers for topical hygiene issues and data exchange between them based on concluding agreements on cooperation (including those involving several parties). These agreements will contain clear substantiation for topicality of a problem being solved and scientific and practical significance of expected results.

The Concept also determines basic trends in personnel policy basing on assessing efficiency of each researcher and a specific share of researchers who are younger than 39 in the overall number of researchers employed by an organization. There will be an increase in activities aimed at training highly qualified personnel as well as attracting young experts via integration of scientific research and educational activities and creation of science and education centers involving HEE that train experts in a required sphere.

There is also intent to establish and develop partnership and accomplish joint research works with foreign scientific centers on basic scientific and practical issues that provide sanitaryepidemiologic welfare of population. A priority here is cooperation with EAEU member states and development of interaction with the WHO, ILO, CCA, IAEA, UNCTAD, OECD, WTO, and other international organizations on topical issues related to sanitary-epidemiologic welfare and development and implementation of activities aimed at providing it.

It seems advisable to consider a possibility to create a center for strategic planning of scientific research in the sphere of hygiene, toxicology, and chemical safety. This center should also have control functions, be able to perform intradepartmental examinations and analysis; it will also generalize results obtained via scientific works and coordinate activities of Problem Commissions in order to draw up up-to-date integrated documents in sanitary legislation, new procedures for sanitaryepidemiologic surveillance, prevention programs and activities.

Overall, it is assumed that if basic strategic goals fixed in the Concept are reached and basic tasks set by it are solved, it will allow:

- providing high-quality scientific and methodical basis and increasing efficiency of control and surveillance activities performed by Rospotrebnadzor;

- increasing contribution made by authorities and organizations within the SanitaryEpidemiologic Service into scientifictechnological and socioeconomic development of the country, including developing and implementing competitive science and engineering products;

- providing authorities and organizations within Rospotrebnadzor system with scienceintense efficient tools for controlling, analyzing, and predicting sanitary-epidemiologic situation;

- making fundamental and applied scientific research correspond to up-to-date international standards and requirements;

- creating conditions for transition to a new high-quality and intense interaction between scientific research organizations and authorities and organizations within Rospotrebnadzor system;

- using research equipment and budgets allocated for research organizations more efficiently; 
- increasing quality of highly qualified personnel training and providing support for young researchers and experts;

- enhancing international scientific cooperation on issues related to providing sanitary-epidemiologic welfare and making it more efficient.

Activities performed by «All-Russian society of hygienists, toxicologists, and sanitary inspectors» will allow consolidating resources and efforts made by the Service aiming at pro- viding sanitary-epidemiologic welfare. This new organization was created as per the Order by the Head of the Service and legally registered on February 02, 2021 by the RF Ministry of Justice.

Funding. The research was not granted any sponsor support.

Conflict of interests. The authors declare there is no any conflict of interests.

\section{References}

1. Schwab K. The Fourth Industrial Revolution. New York, Crown Business Publ., 2017, 192 p.

2. Nekhorosheva L.N. The change of innovative landscape in the context of development «Industry 40» of technological and economic development: problems and priorities. Tsifrovaya transformatsiya ekonomiki i promyshlennosti: problem i perspektivy: monografiya. Sankt-Peterburg: Izdatel'stvo «Sankt-Peterburgskii politekhnicheskii universitet Petra Velikogo», pp. 29-49 (in Russian).

3. Yudaeva K. New Normal for Russia. Ekonomicheskaya politika, 2010, no. 6, pp. 196-200 (in Russian).

4. El-Erian M.A. Navigating the new normal in industrial countries. International Monetary Fund, 2010. Available at: https://www.imf.org/en/News/Articles/2015/09/28/04/53/sp101010 (02.02.2021).

5. Ivanov O.B. Global risks and new challenges human civilization faces. ETAP: ekonomicheskaya teoriya, analiz, praktika, 2020, no. 2, pp. 7-20 (in Russian).

6. World Economic Forum. Third global Risk Reports. Weforum, 2020. Available at: $\mathrm{http} / / \mathrm{www} . \mathrm{weforum} /$ org/events0world-economic-forum-2020 (02.02.2121).

7. Istomina E.A. Protection from new social risks: issues of interdisciplinary research. Rossiiskoe pravo: obrazovanie, praktika, nauka, 2020, no. 4, pp. 63-72 (in Russian).

8. Tuchkova E.G. Problems of implementation socio-economic human rights in the context of the in industrial revolution. Vestnik Universiteta im. O.E. Kutafina (MGYuA), 2019, no. 11, pp. 48-53 (in Russian).

9. Reis J., Spencer P.S. Decision-making under uncertainty in environmental health policy: new approaches. Environ Health Prev. Med, 2019, no. 24, pp. 57.

10. Future Global Shocks. OECD. Better policies for better lives. Available at: http:// www.oecd.org/gov/risk/futureglobalshocks.htm (02.02.2020).

11. Environmental, Health, and Safety Guidelines. General EHS guidelines. International Finance Corporation: World Bank Group, 2020. Available at: https://www.ifc.org/wps/wcm/connect/topics_ext_content/ifc_external_cor-porate_site/sustainability-at-ifc/policies-standards/ehs-guidelines $(02.02 .2020)$.

12. Sheikh H. Cooperation and not isolation will help us fight COVID-19. World Economic Forum, 2020. Available at: https://www.weforum.org/agenda/2020/04/cooperation-not-isolation-will-help-fightcovid-19/ (20.07.2020).

13. Novikov S.M., Shashina T.A., Dodina N.S., Kislitsin V.A., Skovronskaya S.A., Matsyuk A.V., Panchenko S.V., Arakelyan A.A. The experience of empirical research on comparative assessment of radiation and chemical health risks due to exposure to environmental factors. Gigiena i sanitariya, 2019, vol. 98, no. 12, pp. 1425-1431 (in Russian).

14. Revich B.A., Khar'kova T.L., Kvasha E.A. Prodolzhitel'nost' zhizni i smertnost' v megapolisakh [Life expectancy and mortality in megacities]. Chelovek $v$ megapolise: opyt mezhdistsiplinarnogo issledovaniya. In: B.A. Revich, O.V. Kuznetsova eds. Moscow, LENAND Publ., 640 p. (in Russian).

15. Valeulina N.N., Efremova V.M., Beketov A.L., Brylina N.A., Nikiforova E.V., Grechko G.Sh., Kolotova T.S. Otsenka riska dlya zdorov'ya naseleniya ot vozdeistviya khimicheskikh veshchestv, opredelyaemykh v atmosfernom vozdukhe goroda Chelyabinska za 2015-2017 gg. [Assessing health risks caused by exposure to chemicals detected in ambient air in Chelyabinsk in 2015-2017]. Aktual'nye voprosy analiza pri obespechenii sanitarno-epidemiologicheskogo blagopoluchiya naseleniya i zashchity 
prav potrebitelei: materialy IX Vserossiiskoi nauchno-prakticheskoi konferentsii, 2019, pp. 95-100 (in Russian).

16. Fridman K.B., Novikova Yu.A., Belkin A.S. On the issue of the use of health risk assessment techniques for hygienic characteristics of water supply systems. Gigiena i sanitariya, 2017, vol. 96, no. 7, pp. 686-689 (in Russian).

17. Rakitskii V.N., Avaliani S.L., Shashiia T.A., Dodina N.S. Actual problems of population health risks management in Russia. Gigiena i sanitariya, 2018, vol. 97, no. 6, pp. 572-575 (in Russian).

18. Shilova Yu.O., Vitkovskaya S.E. Otsenka vozdeistviya poligona tverdykh bytovykh otkhodov na soderzhanie tyazhelykh metallov v pochve i rasteniyakh [Assessing impacts produced by a solid communal wastes landfill on heavy metal contents in soils and plants]. Tendentsii razvitiya agrofiziki: otaktual'nykh problem zemledeliya i rastenievodstva $k$ tekhnologiyam budushchego: materialy mezhdunarodnoi nauchnoi konferentsii, posvyashchennoi 85-letiyu Agrofizicheskogo NII. SanktPeterburg, 2017, pp. 536-539 (in Russian).

19. Kleyn S.V., Vekovshinina S.A., Balashov S.Yu., Khoroshavin V.A., Ukhabov V.M. Hygienic evaluation of the carcinogenic risk to health of the population living in the zone of the exposure to places of the burial storage of waste of mining and processing enterprises. Gigiena i sanitariya, 2018, vol. 97, no. 1, pp. 10-15 (in Russian).

20. Unguryanu T.N., Gudkov A.B., Nikanov A.N. Health risk assessment of soil contaminants for health of urban population. Profilakticheskaya i klinicheskaya meditsina, 2012, no. 1, pp. 101-105 (in Russian).

21. Kartyshev O.A., Nikolaikin N.I. Criteria of the aviation noise assessment for aerodrome environs zoning of the airports and protective measures justification. Nauchnyi vestnik Moskovskogo gosudarstvennogo tekhnicheskogo universiteta grazhdanskoi aviatsii, 2017, vol. 20, no. 3, pp. 30-40 (in Russian).

22. Onishchenko G.G. Chemical safety is the most important constituent of the sanitary and epidemiological well-being of population. Toksikologicheskii vestnik, 2014, no. 1, pp. 2-6 (in Russian).

23. Khamidulina Kh.Kh. Modern chemical factors' risk and impact management international requirements and their implementation in the system of state sanitary-epidemiologic control. Health Risk Analysis, 2014, no. 2, pp. 14-17. DOI: 10.21668/health.risk/2014.2.02.eng

24. Bukhtiyarov I.V. Current state and main directions of preservation and strengthening of health of the working population of Russia. Meditsina truda i promyshlennaya ekologiya, 2019, vol. 59, no. 9, pp. 527-532 (in Russian).

25. Kuchma V.R., Sukhareva L.M., Rapoport I.K., Shubochkina E.I., Skoblina N.A., Milushkina O.Yu. Population health of children, risks to health and sanitary and epidemiological wellbeing of students: problems, ways of solution and technology of the activity. Gigiena i sanitariya, 2017, vol. 96, no. 10. pp. 990-995 (in Russian).

26. Cattaneo A., Cogoy L., Macaluso A., Tamburlini G. Child health in the European Union. Luxemburg, European Commission Publ., 2012, 134 p.

27. Vicedo-Cabrera A.M., Guo Y., Sera F., Huber V., Schleussner C.F., Mitchell D., Tong S., Lavigne E. [et al.]. Temperature-related mortality impacts under and beyond Paris Agreement climate change scenarios. Climatic Change, 2018, vol. 150, no. 3-4, pp. 391-402. DOI: 10.1007/s10584-018-2274-3

28. Gasparrini A., Guo Y., Sera F., Vicedo-Cabrera A.M. Projections of temperature-related excess mortality under climate change scenarios. The Lancet Planetary Health, 2017, vol. 1, no. 9, pp. e360-e367. DOI: $10.1016 / \mathrm{S} 2542-5196(17) 30156-0$

29. Gileva O.V., Ulanova T.S., Veikhman G.A., Nedoshitova A.V., Stenno E.V. Methodical assurance of the assessment of toxic and essential elements in human biological matrices. Gigiena i sanitariya, 2016, vol. 95, no. 1, pp. 116-121 (in Russian).

30. Kuz'min S.V., Gurvich V.B., Dikonskaya O.V., Nikonov B.I., Malykh O.L., Yarushin S.V., Kuz'mina E.A., Kochneva N.I., Kornilkov A.S. Socio-hygienic monitoring and information analysis systems supporting the health risk assessment and management and a risk-focused model of supervisory activities in the sphere of securing sanitary and epidemiologic public welfare. Gigiena $i$ sanitariya, 2017, vol. 96, no. 12, pp. 1130-1136 (in Russian). 
31. Zemlyanova M.A., Tikhonova I.V. Occurrence of the risks for the development of respiratory diseases in children exposed to the chemical factors of alumina refinery-associated economic activity. Zdorov'e naseleniya i sreda obitaniya, 2019, vol. 320, no. 11, pp. $42-47$.

32. Madeeva E.V., Khankhareev S.S., Bagaeva E.E., Boloshinova A.A. GIS application in the conduct of public health monitoring and inform management decisions. Sanitarnyi vrach, 2014, no. 5, pp. 16-19 (in Russian).

33. Arkhipova O.E., Chernogubova E.A., Likhtanskaya N.V. Spatiotemporal analysis of the incidence of cancer diseases case study of southern regions of Russian Federation. InterKarto. InterGIS, 2018, vol. 24, no. 1, pp. 109-122 (in Russian).

34. Zaitseva N.V., Zemlyanova M.A., Kol'dibekova Yu.V., Zhdanova-Zaplesvichko I.G., Perezhogin A.N., Kleyn S.V. Evaluation of the aerogenic impact of priority chemical factors on the health of the child population in the zone of the exposure of aluminum enterprises. Gigiena $i$ sanitariya, 2019, vol. 98, no. 1, pp. 68-75 (in Russian).

35. Il'ina S.V., Savilov E.D. Technogenic environmental pollution and the effectiveness of vaccination in children's population. Epidemiologiya i vaktsinoprofilaktika, 2009, vol. 47, no. 4, pp. 57-62 (in Russian).

36. Boev M.V., Kryazhev D.A., Boev V.M. Effect of environmental factors on the formation of postvaccinal immunity. Gigiena i sanitariya, 2014, vol. 93, no. 5, pp. 52-54 (in Russian).

37. Zoran M.A., Savastru R.S., Savastru D.M., Tautan M.N. Assessing the relationship between surface levels of $\mathrm{PM}_{2.5}$ and $\mathrm{PM}_{10}$ particulate matter impact on COVID-19 in Milan, Italy. Sci. Total. Environ., 2020, no. 738 , pp. 139825. DOI: 10.1016/j.scitotenv.2020.139825

38. Fattorini D., Regoli F. Role of the chronic air pollution levels in the COVID-19 outbreak risk in Italy. Environ Pollution, 2020, no. 264, pp. 114732. DOI: 10.1016/j.envpol.2020.114732

39. Adhikari A., Yin J. Short-term effects of ambient ozone, $\mathrm{PM}_{2.5}$, and meteorological factors on COVID-19 confirmed cases and deaths in Queens, New York. IJERPH, 2020, no. 17, pp. 4047. DOI: $10.3390 /$ ijerph17114047

Popova A.Yu., Kuzmin S.V., Zaitseva N.V., May I.V. Priorities in scientific support provided for hygienic activities accomplished by a sanitary and epidemiologic service: how to face known threats and new chnallanges. Health Risk Analysis, 2021, no. 1, pp. 4-14. DOI: 10.21668/health.risk/2021.1.01.eng

Received: 20.02 .2021

Accepted: 20.03.2021

Published: 30.03.2021 
UDC 51-76

DOI: $10.21668 /$ health.risk/2021.1.02.eng

Research article

\title{
NUMERIC MODELING OF BACTERIA POPULATION EVOLUTION IN HUMAN LUNGS
}

\author{
N.E. Pil ${ }^{1}$, V.M. Chigvintsev ${ }^{2}$ \\ ${ }^{1}$ Perm National Research Polytechnic University, 29 Komsomolskiy Ave., Perm, 614990, Russian Federation \\ ${ }^{2}$ Federal Scientific Center for Medical and Preventive Health Risk Management Technologies, 82 Monastyrskaya Str., \\ Perm, 614045, Russian Federation
}

\begin{abstract}
The present work focuses on building up a mathematical model showing bacteria population evolution in human lungs taking into account dynamics of immune processes; the model would be useful for assessing functional damage to the lungs. Numeric modeling of processes that occur in a human body is a promising tool for analyzing and predicting impacts exerted by risk factors on health. The suggested approach was developed within a concept describing a human body as a multi-level model that allowed for interaction between various systems and functional state of examined organs given effects produced on them by different adverse factors. Since direct modeling of the structure and processes occurring in the lungs is rather complicated, these organs are usually described with a porous medium model and it requires a lot of computing resources. Damage to the lungs determined via an evolution equation was introduced into the model. The equation described dependence between damage and infiltrate distribution and effects produced on alveolar cells by toxicants excreted by bacteria.

The work dwells on certain results that characterize how concentrations of immune system components and bacteria population are spatially distributed when an immune response is evolving. Our research provides a qualitative insight into reasons for quantitative changes in bacteria population under immune reactions occurring in a body under exposure to different factors. This approach can be used for obtaining more precise parameters for existing population models that show spread and clinical course of bacterial infections and for making a long-term prediction of an epidemiological situation. Results obtained with this approach can be useful for analyzing risks of communicable diseases including those occurring under exposure to adverse environmental factors.

Key words: mathematical modeling, immune response, bacteria population, toxin extraction, functional damage, human lungs, porous medium, multi-component mixture flow.
\end{abstract}

People constantly interact with the environment throughout their lives as they get all the necessary substances from it and are exposed to its adverse effects. Influence exerted on people by adverse environmental factors results in their deteriorating health; contagion with bacterial flora is a possible cause for health disorders.

At present there are different clinical laboratory and functional techniques aimed at observing and examining processes that occur in a human body. Such techniques allow obtaining a complex insight into a current situation with a patient's health. However results obtained via such techniques give a picture of a patient's health only for a moment at which measurements are made and they do not provide any opportunity to make forecasts $[1,2]$. These techniques are based on analyzing various tests with their results being compared with physiological standard ranges; basing on it, experts make conclusions on a patient's health. Besides, a lot of such techniques are rather expensive and labor-consuming.

Mathematical modeling seems to be a completely different approach used for more profound examining and predicting processes that occur in various organs in a body. A lot of field observations that are rather painstaking can be replaced with computing experi-

(C) Pil N.E., Chigvintsev V.M., 2021

Nikita E. Pil - Student (e-mail: nikitapil32@gmail.com; tel.: +7 (919) 467-49-69; ORCID: https://orcid.org/0000-0003-2312-3006).

Vladimir M. Chigvintsev - Candidate of Physical and Mathematical Sciences, Researcher at Mathematic Modeling of Systems and Processes Department (e-mail: cvm@fcrisk.ru; tel.: +7 (342) 237-18-04; ORCID: https://orcid.org/0000-0002-0345-3895). 
ments that involve using mathematical models. Mathematic modeling procedures allow saving time and resources, changing initial conditions, and analyzing a disease development as per different scenarios. It means that the approach is truly universal as we can use the same mathematical model for different cases of the same disease.

Creation of a model that shows how bacterial population evolves in the human lungs is a part of the more general task which is to create a mathematical model for describing a human body as an interconnected set of organs and systems; certain functional damage is to be introduced into it for each organ in order to show an extent to which functions of this organ are distorted [3]. Damage changes within a range from 0 to 1 ( 0 means that there are no functional disorders and 1 mans that an organ doesn't perform its functions at all). This model includes sub-models showing the digestive, immune, endocrine, and respiratory systems [4-6].

Dynamics of pathogenic microorganisms' growth and their spatial distribution can be described with population models. Bearing basic principles description in mind, interesting models seem to be the Monod model [7] stating that number of population depends on a nutrient medium, and the Lotka - Volterra model [8] that describes competition between populations. Cellular automations are used in several works [9-12] to describe how a population is distributed in space. A modeled area is discretized, values of population number are assigned to certain meshes, and rules for a population movement are fixed. These models have a drawback which is a too complicated transfer from two-dimensional tasks to three-dimensional ones as well as difficulties in biophysical interpretation of rules for cellular automations functioning. There are interesting models among those with continuous time [13, 14]; these works focus on evolution processes occurring in bacterial populations used in oil extraction industry. A bacterial population moves due to pressure gradient and diffusion occurrence. The model is described with a system of differential equations in partial derivatives.
Basic principles for building up immunological models are described in the work [15] that concentrates on population of pathogenic microorganisms taken in dynamics and immune system components. Interconnections between elements in the model are built as per «predator - prey» type and are described with a system of non-linear differential equations with retarded argument. Retardation is introduced to describe spatial effects that are not obviously taken into account in the model. The works [16-18] give more detailed description of immune response mechanisms but they fail to take into account spatial distribution of pathogenic population and immune system cells.

Describing immune processes occurring in human lungs in dynamics requires taking into account medium behavior. There are various models that describe human lungs and respiratory processes. The work [19] dwells on actual respiratory tracts geometry; however, this approach to describing processes requires substantial computing resources. It seems promising to use porous medium model and filtration theory to create models showing the lower respiratory tracts $[6,20,21]$.

Therefore, many immunologic models do not obviously describe spatial distribution of examined features in a specific human organ. It seems possible to use approaches and procedures related to mechanics of multi-component mixture flows in porous media taking influence exerted by immunologic processes into account.

Our research goal was to build a mathematical model showing bacterial population evolution in the human lungs taking into account dynamics of immune processes in order to assess functional damage to the lungs.

Data and methods. Communicable diseases involve pathogenic microorganisms penetrating and/or activating in a human body. This work dwells on bacterial population evolution localized in the lower respiratory tracts. Basic features used to describe the population include division rate, parameters determining nutrient medium (substrate) quantity, bacteria being able to move in a medium on their own and to produce toxicants. 
It is well known that it is more energetically beneficial for a body to maintain pathologic antigen concentration on a certain level than remove it completely [15]. A bacterial population starts to grow in case the immune system is weakened due to a previous disease or pathogenic microorganisms penetrating a body from the environment. Simultaneously an immune response mechanism is being activated. As a result there are inflammations where a bacterial population concentrates. Discharge related to immune system reactions leads to a decrease in lung capacity thus resulting in lower oxygen introduction and more frequent breathing. Bacteria produce toxins that have adverse effects on alveoli cells as they deteriorate their barrier and transportation functions.

All the described processes take place in the lower respiratory tracts in the human lungs. The lungs are a set of airways with alveoli as their ends (Figure 1) [22].

Adult lungs contain approximately 600 700 million alveoli and it creates certain difficulties in direct modeling of the overall respiratory tracts hierarchy. And mathematical description of processes that occur in the lungs requires substantial computing resources. These computing difficulties might be overcome via using a porous medium model. The lungs are considered a continuous saturated elastically deformed porous medium. Deformation occurs due to diaphragm contraction or ribs lifting and as a result lung volume decreases, pressure increases, and a person exhales. When a person inhales, lung volume increases and pressure in them drops lower than the atmospheric one, and due to it air enters a human body. This approach is described in great detail in [6].

Porous medium model allows replacing detailed structure of alveoli and alveolar channels (Figure 2) with porosity and permeability. Porosity is a dimensionless value that characterizes a share belonging to pores in a medium and is equal to a ratio between volume of pores and overall volume of a medium that consists of pores and elastic cross connections. Permeability is capacity of a medium to let through liquids and gases.

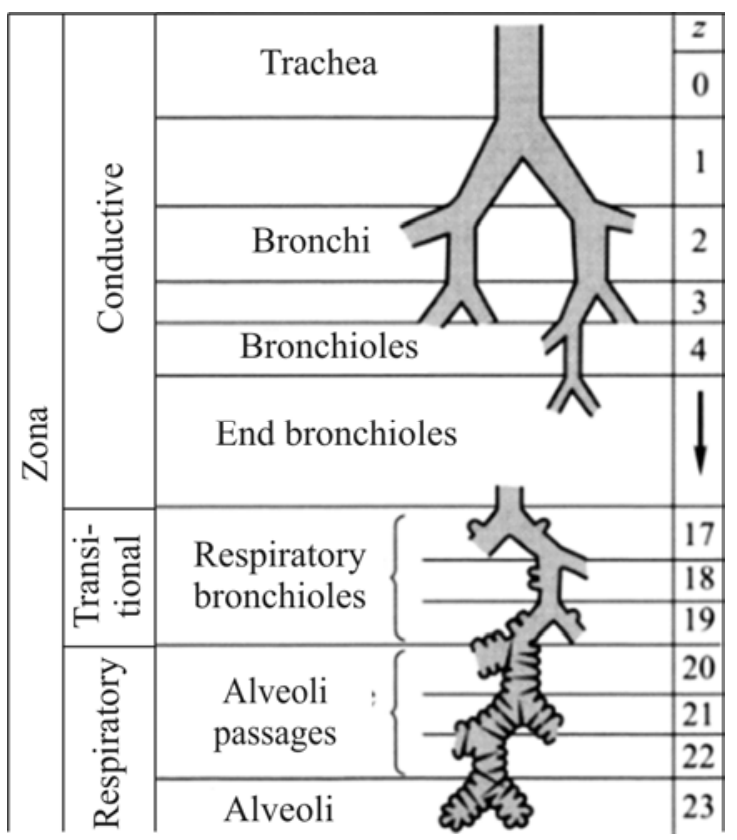

Figure 1. Lower airways dichotomy as per Veibel morphometric model [22]

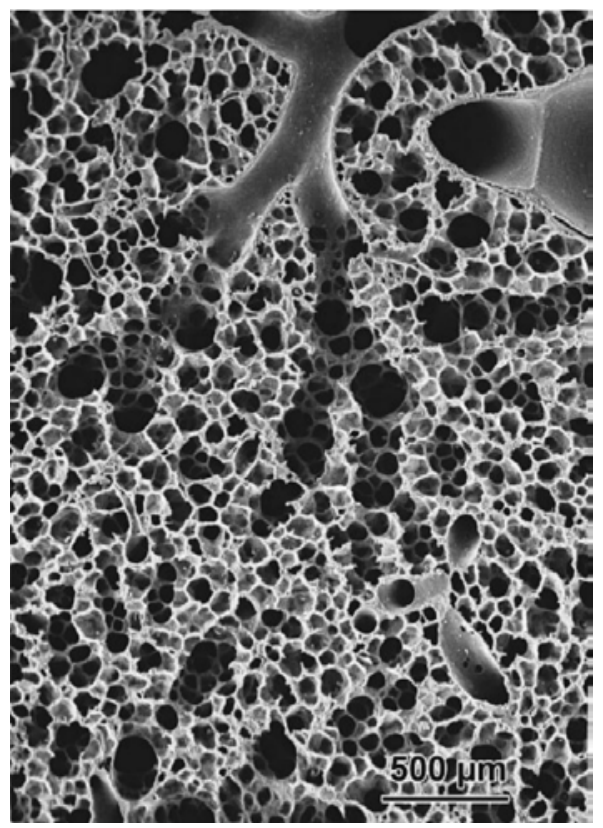

Figure 2. An increased fragment of alveoli [23]

Damage to the lungs changes due to infiltrate occurring during an immune response and influence exerted on alveoli cells by toxicants produced by bacteria. Within porous medium model framework porosity and permeability will go down during an immune response due to alveoli space being obstructed.

Let us consider mathematical task setting; to do that, let us take the following mass balance equation: 


$$
\frac{\partial \rho}{\partial t}+\nabla \cdot(\rho v)=-\nabla \cdot j+S,
$$

where $\rho$ is mixture density, $v$ is velocity vector, $\nabla$ is Hamilton operator, $j$ is diffusion flow vector. Moving on to concentrations and assuming that the mixture is non-compressible, we get the following:

$$
\begin{gathered}
\frac{d C_{i}}{d t}=-\nabla \cdot j_{i}, \\
j=-D \nabla C,
\end{gathered}
$$

where $\frac{d}{d t}=\frac{\partial}{\partial t}+v \cdot \nabla$ is total derivative, $D$ is diffusion coefficient.

Therefore, taking porosity $m$ into account, we get mass transfer equation in porous medium:

$$
\frac{\partial(m C)}{\partial t}+m v \cdot \nabla C=\nabla \cdot(m D \nabla C)+S,
$$

In our first approximation let us consider that the examined components move due to diffusion occurring due to concentration gradients. In this case overall transfer equation is as follows:

$$
\frac{\partial\left(m C_{i}\right)}{\partial t}=\nabla \cdot\left(m D_{i} \nabla C_{i}\right)+S_{i},
$$

where $C_{i}$ is concentration of bacterial population $(i=1)$, substrate $(i=2)$, macrophages $(i=3)$, plasma cells $(i=4)$, antibodies $(i=5)$, and toxins $(i=6)$ accordingly; $S_{i}$ is a mass source of the $i$-th component in the mixture.

Bacterial population grows due to division and substrate consumption and decreases due to natural lysis and effects produced by macrophages and antibodies:

$$
S_{1}=\mu \frac{C_{2}}{k_{1}+C_{2}} C_{1}-k_{2} C_{1}^{2}-\gamma_{13} C_{3} C_{1}-\gamma_{15} C_{5} C_{1} .
$$

Substrate concentration goes down due to it being consumed by a bacterial population and recovers due to regeneration processes:

$$
S_{2}=-k_{3} \mu \frac{C_{2}}{k_{1}+C_{2}} C_{1}+\gamma_{2} f\left(1-\frac{C_{2}}{C_{2,0}}\right) \text {. }
$$

Changes in concentrations of immune system components (macrophages, plasmatic cells, and antibodies) are given as:

$$
\begin{aligned}
& S_{3}=\gamma_{31} \xi C_{3}-\alpha_{3} C_{3}, \\
& S_{4}=\gamma_{4} \xi\left[\rho_{4} C_{3} C_{4}-C_{3} C_{4}\right]-\alpha_{4}\left(C_{4}-C_{4,0}\right), \\
& S_{5}=\rho_{5} \xi C_{4}-\eta_{5} \gamma_{51} C_{5} C_{1}-\alpha_{5} C_{5} .
\end{aligned}
$$

Toxicants concentration is proportionate to bacterial population concentration and goes down due to natural neutralization:

$$
S_{6}=\gamma_{6} C_{1}-\alpha_{6} C_{6} .
$$

The

equations

Ошибка! Источник ссылки не найден.Ошибка! Источник ссылки не найден. with initial and border conditions create a system of equations in partial derivatives that describes bacterial population evolution in a porous medium.

The functions $\xi=\xi(h)$ describe effects produced by damage $h$ on the immune system functioning. Damage grows due to effects produced by toxicants and alveoli obstruction and can decrease due to self-recovery:

$$
\frac{d h}{d t}=a_{1} C_{6}+a_{2} C_{1}-\alpha_{h} h .
$$

Taking into account (9) the system (4)-(8) shows complete mathematical task setting that includes correlations for describing changes in concentration due to diffusion processes and correlations for mass sources occurring as a result of an immune response.

Results and discussion. To test quality of the obtained model, numeric experiments were used; they allowed obtaining spatiotemporal distribution of bacterial population concentrations and concentrations of the immune system components.

At the initial time bacterial population distribution and concentrations were assumed to be known. Bacterial population localization was taken into account, and initial distribution is shown in Figure 3. We considered how bacterial population concentration spread in po- 
rous medium volume. The considered scenario described bacterial population death.

Concentrations of the immune system components were distributed evenly inside the

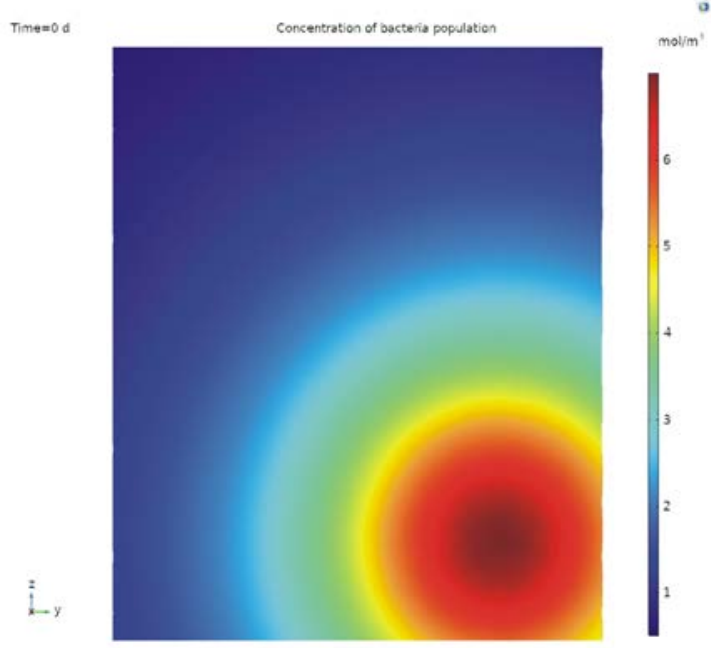

Figure 3. Initial distribution of bacterial population concentration

modeled area. Distribution of toxins concentration coincided with bacterial population distribution at the initial time.

Figure 4 shows spatial distribution of bacterial population concentration during an immune response. Over time a bacterial population grows in volume as its number increases. Then an immune response mechanism is activated and at a certain time (time $=9$ day) we can see a decrease in a bacterial population due to effects produced by macrophages and antibodies.

Figure 5 shows integral curves that describe immune cells population and bacterial population. It is obvious that a bacterial population first grows intensely and it leads to generation and growth in number of immune cells population; pathogenic microorganisms are neutralized and bacterial population decreases.

We also considered another scenario that involved bacterial population survival; it might result in an organ death considering its total inability to perform its basic functions. In this scenario a bacterial population starts to grow uncontrollably and it indicates that an immune response is unable to neutralize pathogenic flora. Integral curves showing number of immune system components and bacteria population are given in Figure 6.

Two considered scenarios had different parameters that characterized the immune system state and parameters that described a bacterial population. These results give a qualitative picture of immune processes occurring due to a bacterial disease in the human lungs. We should note that models that are being developed at the moment are individual in many aspects and depend on peculiarities of a specific body such as age, current state of the immune system, genetics, and diseases in a case history.

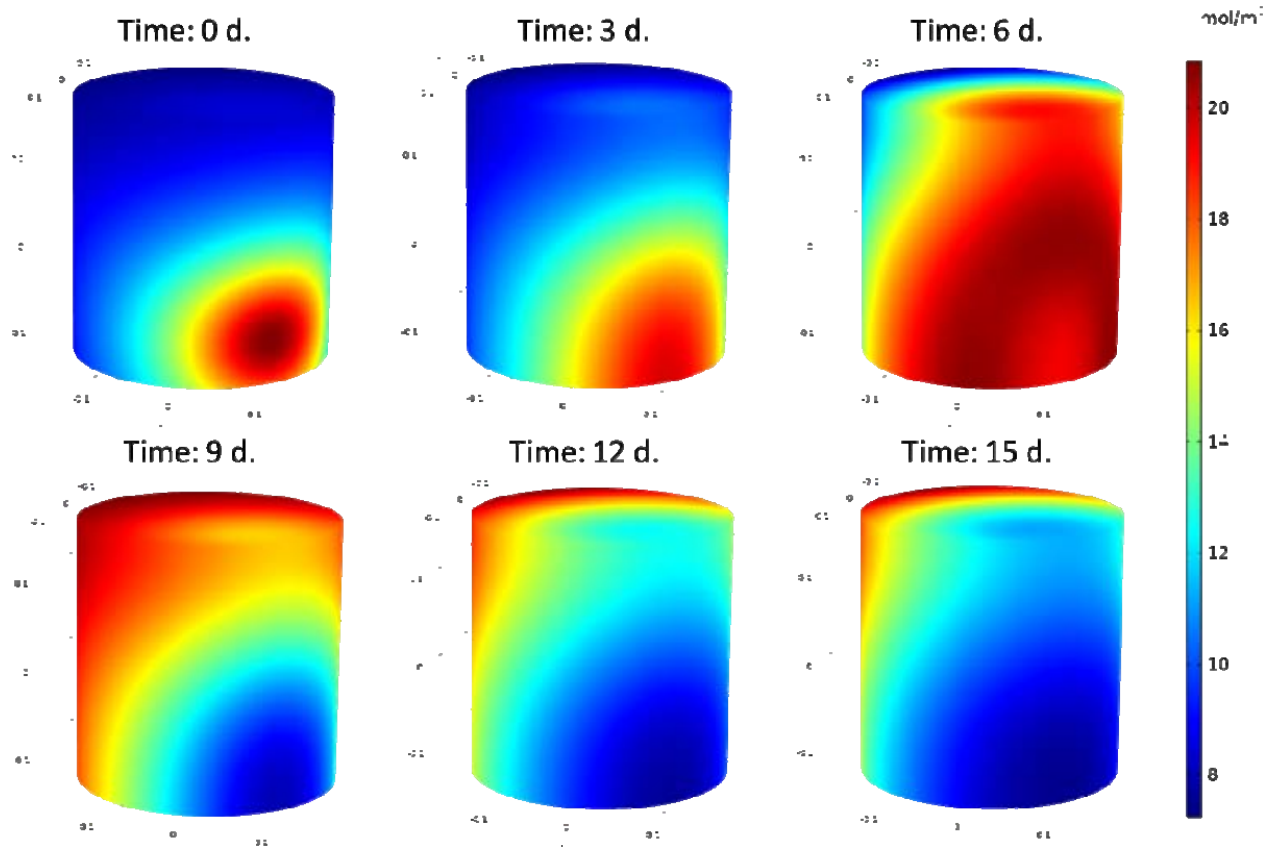


Figure 4. Distribution of the concentration of the bacterial population in a porous medium

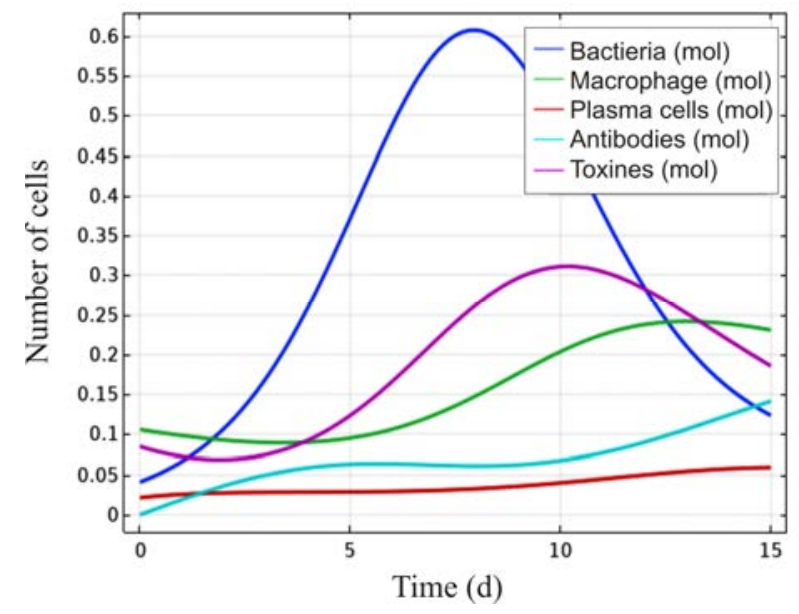

Figure 5. Integral assessment of immune components concentration and bacterial population concentration in the examined volume of porous medium (bacterial population death)

The obtained results are well in line with those given in the works $[14,18]$.

Conclusion. The work dwells on the model showing bacterial population evolution in the human lungs and contains conceptual and mathematical setting. It also focuses on results obtained via numeric experiments that describe scenarios involving either bacterial population death or survival. Immune processes development is determined by a state of a body and bacterial population peculiarities.

In future we plan to take into account influence exerted by breathing on bacterial population cells moving and to enhance a set of immune response elements. We plan to accomplish numeric examinations of effects produced by damage on the immune system functioning in the human lungs.

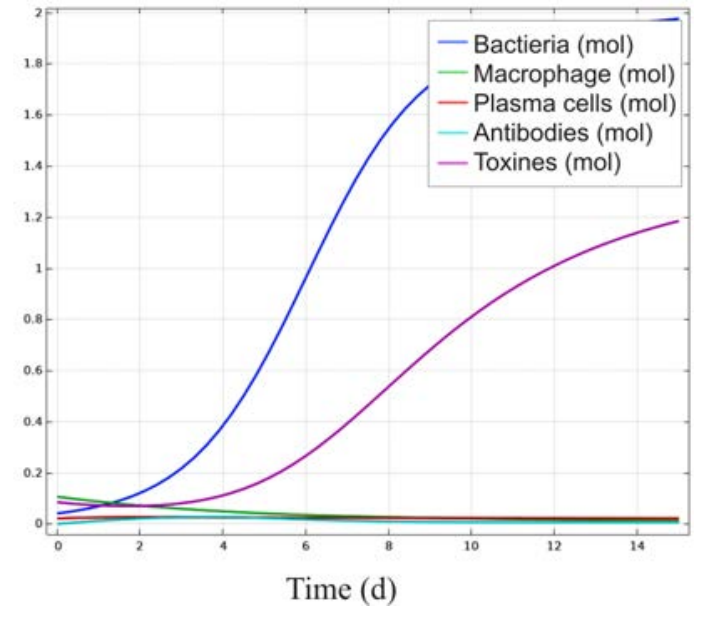

Figure 6. Integral assessment of immune components concentration and bacterial population concentration in the examined volume of porous medium (bacterial population survival)

The described results can be seen as making a certain contribution into developing procedures for mathematical modeling aimed at describing immune response and physics of multicomponent mixture flow in porous media. To make practical use more efficient, it is advisable to enhance a list of immune system components and their interconnections. A promising trend in the model development might be efforts aimed at identifying model parameters and examining the model in order to detect new regularities in immune processes.

Acknowledgements. The authors express their gratitude to Professor Petr V. Trusov for scientific advice and valuable comments on the text.

Funding. The research was not granted any sponsor support.

Conflict of interests. The authors declare there is no any conflict of interests.

\section{References}

1. Grebenev A.L. Propedevtika vnutrennikh boleznei [Preliminary study of internal diseases]. Moscow, Meditsina Publ., 2001, 592 p. (in Russian).

2. Shklyar B.S. Diagnostika vnutrennikh boleznei [Internal diseases diagnostics]. Kiev, Vysshaya shkola Publ., 1972, 516 p. (in Russian).

3. Trusov P.V., Zaitseva N.V., Kir'yanov D.A., Kamaltdinov M.R., Tsinker M.Yu., Chigvintsev V.M., Lanin D.V. A mathematical model for evolution of human functional disorders influenced by environment factors. Matematicheskaya biologiya i bioinformatika, 2012, vol. 7, no. 2, pp. 589-610 (in Russian). 
4. Zaitseva N.V., Shur P.Z., Aminova A.I., Kir'yanov D.A. To estimate the additional risk of diseases of the gastrointestinal tract associated with dysbiosis of the intestinal microflora due to the impact of tetracycline residues in foods. Zdorov'e naseleniya i sreda obitaniya, 2012, vol. 232, no. 7, pp. 46-48 (in Russian).

5. Trusov P.V., Zaitseva N.V., Chigvintsev V.M., Lanin D.V. Regulation of organism's antiviral immune response: mathematical model, qualitative analysis, results. Matematicheskaya biologiya $i$ bioinformatika, 2018, vol. 13, no. 2, pp. 402-425 (in Russian).

6. Trusov P.V., Zaitseva N.V., Tsinker M.Yu. On modeling of airflow in human lungs: constitutive relations to describe deformation of porous medium. Vestnik Permskogo natsional'nogo issledovatel'skogo politekhnicheskogo universiteta. Mekhanika, 2020, no. 4, pp. 165-174 (in Russian).

7. Monod J. The growth of bacterial cultures. Annual Review of Microbiology, 1949, vol. 3, pp. 371-394. DOI: 10.1146/annurev.mi.03.100149.002103

8. Framstad E., Stenseth N.C., Bjornstad O.N., Falck W. Limit cycles of Norwegian lemmings: tensions between phase-dependence and density-dependence. Phil. Trans. R. Soc. Lond. B, 1997, vol. 264, no. 1378 , pp. 31-38. DOI: 10.1098/rspb.1997.0005

9. Butov A.A., Egorov A.G. The model of one-type population dynamics in space and time. Vestnik Kemerovskogo gosudarstvennogo universiteta, 2015, vol. 64, no. 4-3, pp. 121-127 (in Russian).

10. Hong M., Xiaojuan Z. Microbial growth modeling and simulation based on cellular automata. Research Journal of Applied Sciences, Engineering and Technology, 2013, vol. 6, no. 11, pp. 2061-2066. DOI: 10.19026/RJASET.6.3824

11. Klimenko A.E., Matushkin Y.G., Kolchanov N.A., Lashin S.A. Modeling evolution of spatially distributed bacterial communities: a simulation with the haploid evolutionary constructor. BMC Evolutionary Biology, 2015, vol. 15, no. 1, pp. 1-11. DOI: 10.1186/1471-2148-15-S1-S3

12. Harrouet F., Desmeulles G., Redou P., Guabert L. 3D individual based for bacteria growth and spatial interactions: application to the case of Listeria Monocytogenes and Carnobacterium Piscola. Jan Van Impe. Food Sim, 2016, 6 p.

13. Ginak A.I., Kuznetsova S.N., Milovanovich E.V. Simulation of biochemical processes in oil extraction well face zone. Izvestiya Sankt-Peterburgskogo gosudarstvennogo tekhnologicheskogo instituta, 2012, vol. 41, no. 15, pp. 82-83 (in Russian).

14. Kholodonov V.A., Lukina M.V., Milovanovich E.V. Modelirovanie biotekhnologicheskikh i fil'tratsionnykh protsessov povysheniya nefteotdachi plastov [Modeling biotechnological and filtration processes related to a growth in recoverable oil]. Izvestiya Sankt-Peterburgskogo gosudarstvennogo tekhnologicheskogo instituta, 2011, vol. 37, no. 11, pp. 69-71 (in Russian).

15. Marchuk G.I. Matematicheskie modeli v immunologii. Vychislitel'nye metody i eksperimenty [Mathematical models in immunology. Computational approaches and experiments]. Moscow, Nauka Publ., 1991, 304 p. (in Russian).

16. Levchenko O.Yu. Mathematical modeling of antibacterial immune reaction. Politematicheskii setevoi elektronnyi nauchnyi zhurnal kubanskogo gosudarstvennogo agrarnogo universiteta, 2011, no. 66, pp. 60-71 (in Russian).

17. Smith A.M., McCullers J.A., Adler F.R. Mathematical model of a three-stage innate immune response to a pneumococcal lung infection. Journal of Theoretical Biology, 2011, vol. 7, no. 276 (1), pp. 106-116. DOI: 10.1016/j.jtbi.2011.01.052

18. Kuznetsov S.R. Mathematical model of the immune response. Vestnik Sankt-Peterburgskogo universiteta. Prikladnaya matematika. Informatika. Protsessy upravleniya, 2015, no. 4, pp. 72-87 (in Russian).

19. Lambert A.R. Regional deposition of particles in an image based airway model: CFD simulation and left-right lung ventilation asymmetry. Iowa, University of Iowa Publ., 2010, 68 p.

20. De Groot C.T., Straatman A.G. A conjugate fluid-porous approach for simulating airflow in realistic geometric representations of the human respiratory system. Journal of Biomechanical Engineering, 2016, vol. 138, no. 3, pp. 4032113. DOI: 10.1115/1.4032113 
21. DeGroot C.T., Straatman A.G. Towards a porous media model of the human lung. 4th International Conference on Porous Media and its Applications in Science: AIP Conference Proceedings, 2012, vol. 1453, no. 1, pp. 69-74. DOI: 10.1063/1.4711155

22. Veibel' E.R. Morfometriya legkikh cheloveka [Human lungs morphometry]. Moscow, Meditsina Publ., 1970, 175 p. (in Russian).

23. Weibel E.R. What makes a good lung? Swiss Med. Wkly, 2009, vol. 139, no. 27-28, pp. 375-386.

Pil N.E., Chigvintsev V.M. Numeric modeling of bacteria population evolution in human lungs. Health Risk Analysis, 2021, no. 1, pp. 15-22. DOI: 10.21668/health.risk/2021.1.02.eng

Received: 01.03.2021

Accepted: 19.03.2021

Published: 30.03 .2021 
UDC 616.24: 578.834.1]: 519.24

DOI: 10.21668/health.risk/2021.1.03.eng

Research article

\title{
SPATIO-TEMPORAL MODELING OF COVID-19 EPIDEMIC
}

\author{
V.L. Sokolovsky ${ }^{1}$, G.B. Furman ${ }^{1}$, D.A. Polyanskaya ${ }^{2}$, E.G. Furman ${ }^{2}$ \\ ${ }^{1}$ Ben Gurion University of the Negev, P.O.B. 653, Beer-Sheva, 84105, Israel \\ ${ }^{2}$ Perm State Medical University named after Academician E.A. Wagner, 26 Petropavlovskaya Str., Perm, 614000, \\ Russian Federation
}

In autumn and winter 2020-2021 there was a growth in morbidity with COVID-19. Since there are no efficient medications and mass vaccination has only just begun, quarantine, limitations on travels and contacts between people as well as use of personal protection equipment (masks) still remain priority measures aimed at preventing the disease from spreading.

In this work we have analyzed how the epidemic developed and what impacts quarantine measures exerted on the disease spread; to do that we applied various mathematical models. It was shown that simple models belonging to SIR-type (S means susceptible; I, infected; and $R$, recovered or removed from the infected group) allowed estimating certain model parameters such as morbidity and recovery coefficients that could be used in more complicated models.

We examined spatio-temporal epidemiologic models based on finding solutions to non-stationary two-dimensional reaction-diffusion equations. Such models allow taking into account uneven distribution of population, changes in population mobility, and changes in frequency of contacts between susceptible and infected people due to quarantine. We applied obtained analytical and numerical solutions to analyze different stages in the epidemic as well as its wave-like development influenced by imposing and canceling quarantine limitations.

To take into account ultimate rate at which the disease spreads and its incubation period (when an infected person is not a source of contagion), we suggest using equations similar to the Cattaneo-Vernotte one. The suggested model allows predicting where the front of morbidity spread is going to occur, that is, a moving frontier between areas where there are infected people and areas where they are absent. Use of such models provides an opportunity to introduce differential quarantine measures basing on more objective grounds.

At the end of 2020 mass vaccination started in some countries. We estimated a necessary number of people that had to be vaccinated so that new waves of COVID-19 epidemic would be prevented; in our estimates, not less than $80 \%$ of the country population should be vaccinated.

Correct prediction of epidemic development is becoming more and more vital at the moment due to new and more contagious COVID-19 virus strains occurring in England, South Africa, and some other countries.

Our research results can be used for predicting spread of COVID-19 and other communicable diseases; they can make for taking the most efficient measures for successful control over epidemics.

Key words: spatio-temporal modeling, epidemic, COVID-19, morbidity, non-stationary two-dimensional reactiondiffusion equations, quarantine, contagion rate, recovery rate.

Researchers predict that morbidity with COVID-19 will grow in winter 2020-2021 [1]. In autumn 2020 there is an intense growth in number of people infected with COVID-19 all over the world and it is the second pandemic wave. Lockdown is again introduced in some European countries and RF regions as well. In Israel there was a repeated rapid growth in morbidity in late August and September, and it was only strict lockdown introduced at the end of September and was valid for the whole October that allowed reducing quantity of everyday contagion cases and seriously ill patients as well as patients who needed to be switched to artificial lung ventilation devices.

(C) Sokolovsky V.L., Furman G.B., Polyanskaya D.A., Furman E.G., 2021

Vladimir L. Sokolovsky - Candidate of Sciences, Professor at the Physics Department (e-mail: sokolovv@bgu.ac.il; tel.: +9 (725) 464-703-40; ORCID: https://orcid.org/0000-0003-4887-413X).

Grigoriy B. Furman - Candidate of Sciences, Professor at the Physics Department (e-mail: gregoryf@bgu.ac.il; tel.: +9 (725) 476-842-45; ORCID: https://orcid.org/0000-0001-7303-9414).

Darya A. Polyanskaya - Candidate of Medical Sciences, Lecturer at the Hygiene Department of the Medical and Prevention Faculty (e-mail: daryasp88@gmail.com; tel.: +7 (909) 731-11-37; ORCID: https://orcid.org/0000-0002-1466-7039).

Evgeniy G. Furman - Corresponding member of the RAS, Doctor of Medical Sciences, Professor, Head of the Department for Faculty and Hospital Pediatrics (e-mail: furman1@yandex.ru; tel.: +7 (912) 883-97-35; ORCID: https://orcid.org/0000-0002-1751-5532). 
Since there are no efficient medications and vaccines against COVID-19, basic means that can prevent the disease spread are still lockdowns, limitations on travelling and contacts between people, as well as personal protection means such as facial masks. On one hand, lockdown introduction leads to a decrease in number of sick people and burden on a public healthcare system. On the other hand, lockdown results in a fall in economic activities, especially regarding trade, tourism, culture, and entertainment; it also results in deteriorating quality of education and does certain damage to mental state of population. Lockdown should be introduced basing on analyzing how a disease spreads and mathematical models that take into account specific peculiarities of a given disease and are able to predict its spread. Developed procedures for mathematical modeling are significant not only for predicting COVID-19 spread and making for the most efficient measures being taken but also for successful fighting against future epidemics.

Various mathematical models showing epidemic development were developed and applied when analyzing variable diseases spread (typhus, cholera, Ebola, etc.) [2-7]. These models, as well as some new ones that took into account COVID-19 peculiarities, were used for simulating COVID-19 epidemic [8-15]. Starting from the very beginning of COVID-19 epidemic, more than 11 thousand articles have been published in scientific journals and on specialized web-sites, as well as in medRxiv, bioRxiv and arXiv archives; these works focus on various aspects of the disease including statistics and analysis of its spread. Most models are based on the SIR ( $S$ - susceptible, $I$ - infected, $R$ - removed from infected or recovered) epidemic model and its modifications.

These models are based on an assumption that susceptible, infected, and recovered people are spatially distributed evenly. But in actual conditions these population groups are distributed extremely unevenly even in small countries and megacities. There are also several models that take into account uneven spatial distribution of susceptible and infected people [2, 4, 7]. Reaction-diffusion epidemi- ologic models belong to such models with a disease spread being given in them with a system of heat conductivity equations with chemical reaction. However, these models do not take into account natural daily people migration (home, work, educational establishments, cultural institutions, etc.). Another drawback is an assumption that virus is caught from infected people instantly and it simultaneously moves people from susceptible into infected ones and as a result a disease spreads with infinite rate.

Our research goal is to analyze spread of COVID-19 epidemic using various epidemiologic mathematical models. Spatio-temporal epidemic modeling is based on analytical and numerical solutions to non-stationary twodimensional reaction-diffusion equations as well as these equations that model a time lag in a disease occurrence.

Data and methods. In the $1^{\text {st }}$ section of Results and discussion, we used the SIR model and statistical data to determine morbidity and recovery coefficients; then, introducing dependences of these coefficients on time, we modeled a wave-like epidemic caused by lockdown being introduced and canceled. In the next section we showed that morbidity and recovery coefficients determined with the SIR model could be used in reaction-diffusion epidemiologic models; we also analyzed twodimensional spread of the disease. In the $3^{\text {rd }}$ section we modernized reaction-diffusion epidemiologic models and it allowed us to model spatio-temporal epidemic development taking into account daily population migration. In the $4^{\text {th }}$ section we introduced a reaction-diffusion epidemiologic model with finite contagion time. The suggested model predicts that a front of the disease spread will occur, that is, a moving frontier between areas where there are infected people and areas where they are absent.

Results and discussion. 1. SIR epidemic model. In this section we consider the simplest SIR model that allows assessing COVID-19 epidemic dynamics in the $1^{\text {st }}$ approximation and is a basis for developing more precise models. Within the SIR epidemic model population is divided into groups that do not overlap and number of people in them changes over time $[2-4,6,9]$. A «susceptible» group 
includes people who are prone to infection but who are not sick yet. The number of susceptible group $S(t)$ goes down due to people moving to an «infected» group: number of infected people $I(t)$ goes down due to people making full recovery or dying $(R(t))$. Recovered people are assumed to have immunity; transfer from one group to another does not depend on age, sex, social status, etc.

Basic assumptions that underlie use of this model are the following:

- each person from the susceptible group contacts infected ones and there is a certain probability that he or she will also get infected, that probability does not depend on time;

- infection rate is proportionate to a number of infected people as well as quantity of susceptible people;

- each infected person, in his or her turn, is constantly likely to recover at a certain time unit;

- recovery rate is proportionate to a number of infected people;

- a recovered person has immunity and is not susceptible to repeated infection.

SIR model equations can be given as:

$$
\begin{aligned}
& \frac{d s}{d t}=-\alpha_{1} s i \\
& \frac{d i}{d t}=\alpha_{1} s i-\alpha_{2} i \\
& \frac{d r}{d t}=\alpha_{2} i
\end{aligned}
$$

where $\quad s(t)=S(t) / N, \quad i(t)=I(t) / N$, $r(t)=R(t) / N, \quad \alpha_{1}$ and $\alpha_{2}$ are the morbidity and recovery coefficients respectively. These coefficients usually have dimension 1/day (1/d). Here it is assumed that population number

$$
S(t)+I(t)+R(t)=N
$$

is constant.

Numeric solution to the equations (1)-(3) at $\alpha_{1}=0.41 / \mathrm{d}, \alpha_{2}=0.11 / \mathrm{d}$ and initial conditions $s(0)=1, i_{0}=i(0)=10^{-6}$ and $r(0)=0$ is given in Figure 1.

$i(0)=10^{-6}$ for such countries as Israel, Greece, Sweden, as well as for megacities (Moscow, Saint-Petersburg) means that an epi- demic started with approximately 10 infected persons. Initial number of infected persons $i(0)$ (zero patients) does not influence the maximum number of infected $i_{m}$ and recovered people by the end of an epidemic $r_{l}=\left.r(t)\right|_{t \rightarrow \infty}$ (Figure 1). An epidemic will end up naturally when collective immunity is achieved and there are no new infected people. Variations in initial number of infected people lead to changes in a period of time during which an epidemic reaches its peak and then ends.

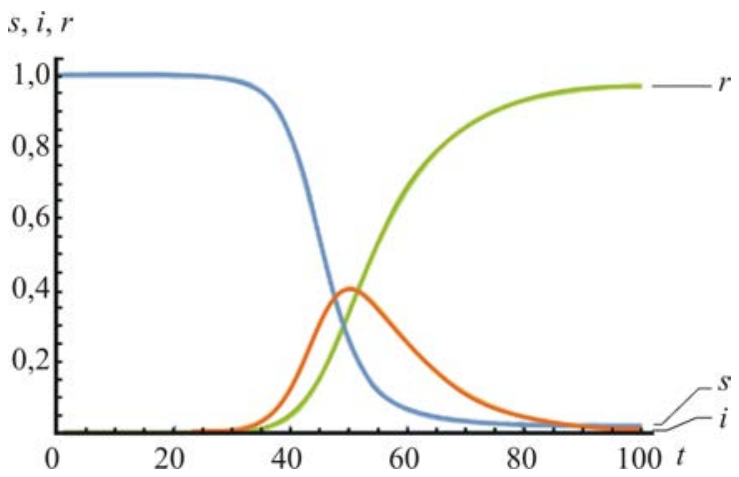

Figure 1. Solution to equations (1)-(3) at $R_{0}=4, \alpha_{1}=0.41 / \mathrm{d}$ and $\alpha_{2}=0.11 / \mathrm{d}$

Parameters $\alpha_{1}$ and $\alpha_{2}$ determine growth rates for a number of infected $i(t)$ and recovered $r(t)$ people. When an epidemic has just started and $i$, we can consider $s(t)=1$. On October 30, 2020 approximately 45.7 million people out of 7.8 billion world population all over the world got infected starting from the beginning of the epidemic; approximately $0.6 \%$ out of them (1.2 million) died (lethality is equal to $2.6 \%$ ). In Israel, approximately 314 thousand people out of 9.5 million are infected, that is, approximately $3 \%$, and 2,511 people died (lethality is $0.8 \%$ ). Despite COVID-19 epidemic has been lasting for several months already and there are huge numbers of people who got infected and died from COVID-19, approximation $s(t) \approx 1$ still holds quite satisfactorily. When performing mathematical modeling, we can also assume that all infected people recover.

At an initial stage in an epidemic a solution to the system of equations (1)-(3) is given as 


$$
\begin{gathered}
s(t) \approx 1 \\
i(t)=i_{0} e^{\alpha_{2}\left(R_{0}-1\right) t} \\
r(t)=\frac{1}{R_{0}-1}\left[e^{\alpha_{2}\left(R_{0}-1\right) t}-1\right]
\end{gathered}
$$

Basic reproduction number, that is, how many people are infected by a single infected person, $R_{0}=\frac{\alpha_{1}}{\alpha_{2}}$ is a significant parameter that determines a character of an epidemic, maximum number of infected $i_{m}$ and recovered people by the end of an epidemic $r_{l}$ (Figure 2) [10].

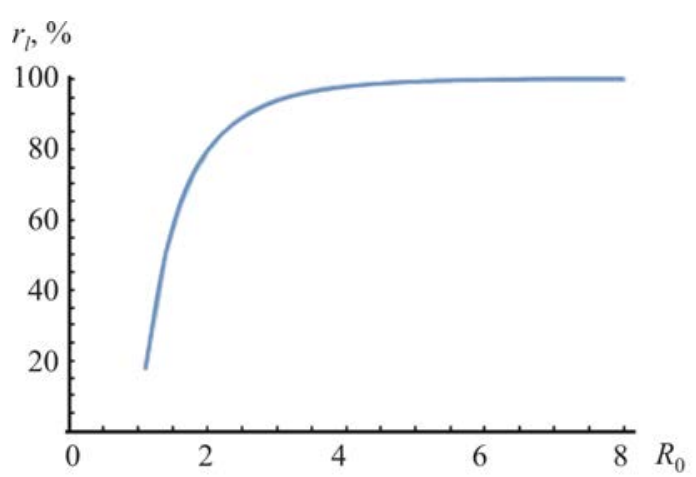

Figure 2. Number of recovered people by the end of an epidemic $r_{l}=\left.r(t)\right|_{t \rightarrow \infty}$ as a function of $R_{0}$ at $\alpha_{2}=0.11 / \mathrm{d}$ and initial conditions $s(0)=1$,

$$
i(0)=i_{0}=10^{-6} \text {, and } r(0)=0
$$

At $R_{0}<1$ a number of infected people goes down naturally without anti-epidemic measures being taken; an epidemic ends up.

At $R_{0}>1$ an epidemic will develop until collective immunity is formed. When basic reproduction number is low, $R_{0}=1.1$, collective immunity is formed when approximately $18 \%$ population overcame the disease (recovered people) at $\alpha_{1}=0.111 / \mathrm{d}, \alpha_{2}=0.11 / \mathrm{d}$ (Figure 2). This percent grows rapidly as $R_{0}$ increases and reaches $94 \%$ at $R_{0}=3$.

Computations have revealed that a share of infected (recovered) people that is necessary for collective immunity formation when a number of new infected people is about zero does not at all depend on parameters $\alpha_{1}$ and $\alpha_{2}$, and basically is determined by their ratio. However, a period of time necessary for reaching this immunity is inversely proportionate to these parameters: at $\alpha_{1}=0.31 / \mathrm{d}$ and $\alpha_{2}=0.11 / \mathrm{d}$ this period is estimated as being equal to 130 days; at $\alpha_{1}=0.031 / \mathrm{d}$ and $\alpha_{2}=0.01 \mathrm{1} / \mathrm{d}$, to 1,300 days.

The maximum number of infected people $i_{m}$ is also determined by a basic reproduction number $R_{0}$, and a period of time necessary to reach it starting from the beginning of an epidemic is determined by $\alpha_{1}$ and $\alpha_{2}$ parameters. The maximum number of infected people $i_{m}$ is reached at $s=\alpha_{2} / \alpha_{1}$ and overall number of infected were $N\left(1-1 / R_{0}\right)$. Further epidemic development is associated with a decrease in number of infected people though their number can reach greater values (Figure 1).

1.1. Model parameters assessment. Parameters that are components in SIR and other models cannot be measured directly since they depend on numerous factors, such as population density, population mobility, social contacts, lockdowns and how people adhere to quarantine measures, age structure of population, etc. $[8,9,10,16]$. Assessments are based on statistical data, their completeness and validity, as well as on establishing a clear correlation between them and «external» factors such as lockdown introduction, seasonal fluctuations, vacations and holidays, that determine authenticity of obtained estimations. Contagion intensity and, consequently, model parameters will depend on time [10, 16, 17]. Basic reproduction numbers $R_{0}$ given in literature depend not only on a country and time of analysis but also on an applied epidemiologic model [10, 17]. The authors of publication [11] estimated basic reproduction number $R_{0}$ at the beginning of the epidemic in European countries as being equal to $4.22 \pm 1.69$, with its maximum value 6.33 detected in Germany. By May 10, 2020 this number went down to $0.67 \pm 0.18$. In October there is a new growth in morbidity, that is, the second epidemic wave [10].

Now we estimate SIR model parameters for Israel using data given on Worldometers web-site that allows one to track daily numbers 
of infected, recovered, and dead people [18]. At the beginning of the epidemic starting from March 1 to 30 a number of confirmed infected people $i(t)$ grows from 10 to 5,114 (Figure 3); there are only 244 recovered people over this period, that is, less than $5 \%$. Parameter $\alpha_{1}$, a growth rate for a number of infected persons, is estimated as $0.21 \pm 0.09$; a number of infected ones doubles approximately each three days. This estimate is well in line with figures given for Israel and France [16, 17].

Active Cases

(Number of Infected People)

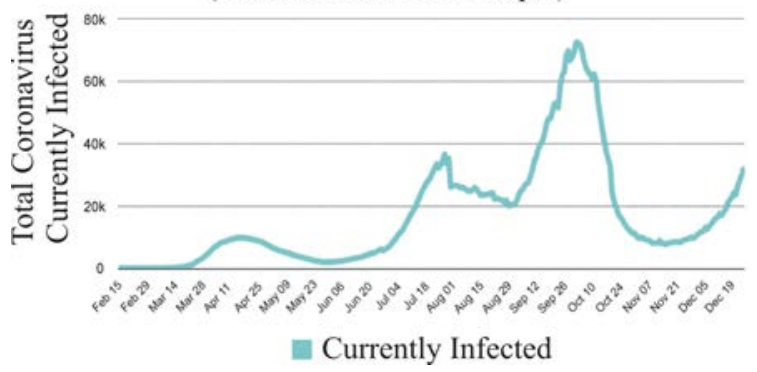

Figure 3. Time dependence for a number of infected $i(t)$ in Israel [8]

Parameter $\alpha_{2}=0.045 \pm 0.03$, recovery rate, is obtained basing on data collected after strict lockdown was introduced from May 4 to 27, when a number of confirmed infected people $i(t)$ amounted to several thousands, and average daily number of new infected people did not exceed 30 . Typical recovery time, that is a time of double decrease in a number of infected amounts 15.5 days. Further we assume that parameter $\alpha_{2}$ does not change during the pandemic.

When quarantine restrictions are eased off, it is accompanied with the $2^{\text {nd }}$ epidemic wave and a number of infected people grows exponentially as per a time depending exponent: June 2-22, 0.04 1/day; June 22-27, 0.045 1/day; June 27 - July 8, 0.079 1/day. Bearing in mind that the exponent characterizing an increase in a number of infected people is $\alpha_{1}-\alpha_{2}$, parameter $\alpha_{1}$ is estimated to be equal to $0.085 ; 0.09$; and 0.124 for these time intervals respectively.

At the beginning of the epidemic $R_{0}$ can be estimated as 4.5 without any quarantine measures or individual or social protection measures being taken. When $R_{0}$ has such a high value, col- lective immunity will be formed only when more than $95 \%$ population have been infected and recovered (Figure 4).

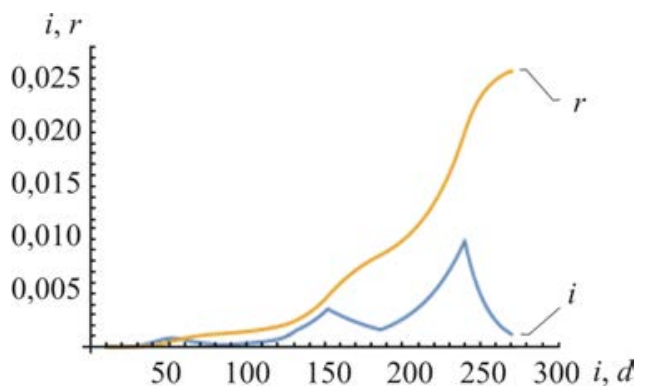

Figure 4. Modeling the pandemic in Israel

This threshold value for collective immunity formation is well in line with predictions made in other works [19]. Some researchers think that $R_{0}$ goes down with time, and this threshold will be substantially lower, however, not lower than several dozen per cent (now registered infected and recovered people account for approximately $3 \%$ of the population) $[10,17,19]$. At the beginning of the $2^{\text {nd }}$ epidemic wave on June $2-22 R_{0}=1.9$; and it is growing as the pandemic develops: June 22-27, $R_{0}=2$; June $27-$ July $8, R_{0}=2.8$.

After July 8 there are strong daily fluctuations that do not allow assessing parameters reliably. In the next part we are planning to use effective values for long time intervals.

1.2. Wave-like pandemic. Results obtained via modeling the pandemic in Israel and the solution to the equations (1)-(3) is given in Figure 3 , and this simulation quite corresponds to morbidity growth (Figure 3). The beginning of the epidemic is characterized with exponential grow thin a number of infected people over time $\sim \operatorname{Exp}(\alpha t)$ prior to strict lockdown was introduced in early April and an exponential decrease in this number in May, $\alpha=\alpha_{1}-\alpha_{2}<0$. Step-bystep quarantine measures cancelling in late May - early June resulted in a new increase in a number of infected people with parameter $\alpha_{1} \approx 0.1$ growing over time. In July and August, when there are vacations in educational establishments, vacations for workers, and still valid quarantine measures, this number goes down. The beginning of the academic year causes a new growth in a number of infected people with $\alpha_{1} \approx 0.09$ and it is only the repeated most strict 
lockdown introduced in late September that leads to the disease spread slowing down.

In Israel in November quarantine measures are being gradually cancelled. We can predict further epidemic development basing on parameter $\alpha_{1}$ values for June-July and September. These values are substantially lower than at the beginning of the pandemic, $0.21 \pm 0.09$. It is due to people wearing face masks in public places, ban on any mass events, distance learning, etc. Figure 5 shows modeling results. As we can see, a slight change in parameter $\alpha_{1}$ results in substantial changes in the results. Thus, at $\alpha_{1}=0.09$ it is predicted that a threshold value for a number of infected people (approximately 75 thousand), when the second lockdown is introduced, is reached in 52 days, and at $\alpha_{1}=0.1$ this threshold value is reached in 42 thousand. Figure 5 shows a range for probable pandemic development.

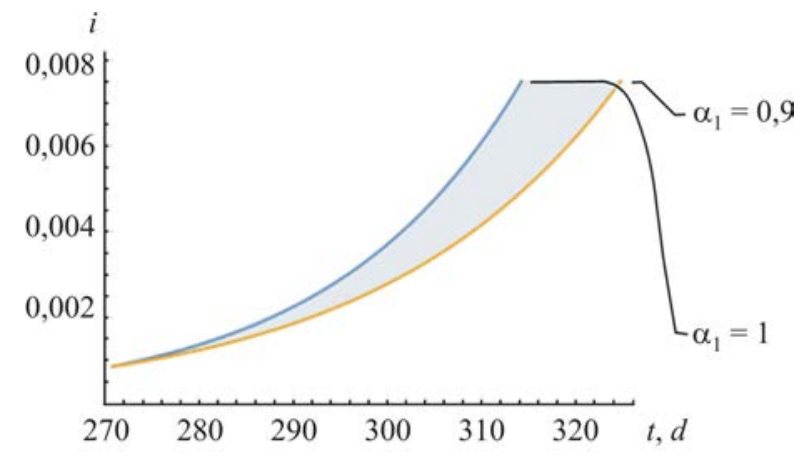

Figure 5. Pandemic prediction

After October 20 some quarantine measures were step-by-step cancelled as nonfood shops and trade centers were opened, children returned to schools, etc. In mid-November there was a new exponential growth (Figure 3) in a number of infected people, and it went up to 17,500 over 20 days; more than 30 thousand, over 30 days; and approximately 49 thousand, over 40 days. Our predictions are well in line with values given in Figure 5.

On December 28 the third lockdown (strict quarantine) is introduced in Israel.

The simplest SIR model contains two parameters $\alpha_{1}$ and $\alpha_{2}$ that depend on many factors (type of a disease, population density, age structure, mobility, etc.) and in more common case on time. These parameters are determined basing on epidemic development in a given country, region, or a city. SIR model allows, assessing significant parameters at least at a first approximation including spread of a disease, burden on medical organizations, necessary number of beds in hospitals, and expected mortality. The latter can be estimated as relevant shares of infected people. However, this model does not take into account an actual clinical course of a disease and such factors as incubation, the illness itself, various clinical courses of a disease, age-related differences, etc. Several more realistic models were developed that allow one to account the abovementioned and other factors as well as specific peculiarities of various diseases [4-12, 17, 20, 21]. These models are based on an assumption that susceptible, infected, and recovered people are distributed evenly over space and a pandemic is described with finding solutions to usual differential equations of (1)-(3) type. However, in reality infected people, even in such a small country as Israel, are distributed extremely unevenly and their distribution is not proportionate to population density. Even on large cities there are districts with different morbidity levels. There are several models that take into account uneven distribution of susceptible, infected, and other people [2, 21-23]. Reaction-diffusion epidemiologic models belong to this category $[2,4,7,22]$.

2. Reaction epidemiologic model. Mathematical description of reaction-diffusion epidemiologic models contains a system of equations in partial derivatives similar to equations that describe diffusion with a chemical reaction $[2,4,7,22]$. A number of equations and a type of members that correspond to are action depend on a chosen model for infection transfer, number of examined population groups distinguished as per age and activity (schoolchildren, working population, retired people etc.). Reaction-diffusion model parameters such as diffusion coefficients characterize mobility of a given population group. Some authors take into account natural changes in population number due to birthrate and mortality as well as mobility of recovered people who have immunity [22]. However, this population group does not influence dynamics of a disease and can be neglected when an epidemic is analyzed. 
Most research works dwell on onedimensional models but we are going to concentrate on a more realistic two-dimensional one $[2,22]$. Let us start with a simple twodimensional model based on SIR model that allows obtaining several analytic solutions along with numerical ones:

$$
\begin{gathered}
\frac{\partial s_{n}}{\partial t}=a_{s}\left(\frac{\partial^{2} s_{n}}{\partial x^{2}}+\frac{\partial^{2} s_{n}}{\partial y^{2}}\right)-\alpha_{d 1} s_{n} i_{n} \\
\frac{\partial i_{n}}{\partial t}=a_{i}\left(\frac{\partial^{2} i_{n}}{\partial x^{2}}+\frac{\partial^{2} i_{n}}{\partial y^{2}}\right)+\alpha_{d 1} s_{n} i_{n}-\alpha_{d 2} i_{n}
\end{gathered}
$$

where $a_{s}$ and $a_{i}$ are the parameters that characterize mobility of susceptible and infected people, respectively, $s_{n}$ and $i_{n}$, are their normalized densities in an examined area. Let us note that density of recovered people $\left(r_{n}\right)$ can be determined via finding solutions to equations (8), (9) and

$$
\frac{\partial r_{n}}{\partial t}=a_{i}\left(\frac{\partial^{2} r_{n}}{\partial x^{2}}+\frac{\partial^{2} r_{n}}{\partial y^{2}}\right)+\alpha_{d 2} r_{n}
$$

Let us assume that parameters $a_{s}, a_{i}, \alpha_{d 1}$, and $\alpha_{d 2}$ do not depend on time and coordinates.

It is convenient to use dimensionless variables: $\tau=a_{s} t, \xi=x \sqrt{\frac{\alpha_{d 1}}{a_{s}}}, \eta=y \sqrt{\frac{\alpha_{d 1}}{a_{s}}}$ in equations (8)-(9); the equations are rewritten as:

$$
\begin{gathered}
\frac{\partial s_{n}}{\partial \tau}=\frac{\partial^{2} s_{n}}{\partial \xi^{2}}+\frac{\partial^{2} s_{n}}{\partial \eta^{2}}-s_{n} i_{n}, \\
\frac{\partial i_{n}}{\partial \tau}=\frac{a_{i}}{a_{s}}\left(\frac{\partial^{2} i_{n}}{\partial \xi^{2}}+\frac{\partial^{2} i_{n}}{\partial \eta^{2}}\right)+s_{n} i_{n}-\frac{\alpha_{d 2}}{\alpha_{d 1}} i_{n}
\end{gathered}
$$

In these equations there are two parameters that characterize spread of a disease: the first one $\frac{a_{i}}{a_{s}}$ is a ratio of values that characterize mobility of infected and susceptible people (should not exceed 1); the second one, $\frac{\alpha_{d 2}}{\alpha_{d 1}}$, is an inverse value of $R_{0}$ analogue. Boundary conditions depend on what surrounds the considered territory. When it comes down to Israel and some other countries with relatively small squares that imposed strict limitations on mov- ing into and out of country people, as well as to some remote Russian regions, we can believe that a flow of infected and susceptible people across a border $\Gamma$ is equal to zero, that is:

$$
\left.\frac{\partial s_{n}}{\partial \vec{n}}\right|_{\Gamma}=0 \text { and }\left.\frac{\partial i_{n}}{\partial \vec{n}}\right|_{\Gamma}=0,
$$

where $\vec{n}$ is a single vector which is normal to boundary $\Gamma$.

Figure 5 shows how an epidemic develops in a square area $\{-4<\xi<4 ;-4<\eta<4\}$ with initial conditions $\quad i_{n}(0, \xi, \eta)=0.0001 \operatorname{Exp}\left[-20\left(\xi^{2}+\eta^{2}\right)\right]$ and $S_{n}=1$ in the whole area. All calculations used in the present work were accomplished with Mathematica 12.

As we can see, when $\tau \geq 5$, infected people are distributed practically evenly, and a model belonging to SIR type similar to that described in the previous section can be applied in further analysis of an epidemic development. For the given initial and boundary conditions, a time needed for reaching a uniform distribution of infected people is estimated as several (3-5) characteristic diffusion time $\tau_{x}=\frac{L^{2}}{\pi^{2}}$, where $L$ is a half of a square side.

People who were infected with coronavirus infection account for a relatively small share of the total population, therefore COVID-19 epidemic can be assumed to be at its initial stage. Non-uniform spatial distribution of infected people at this stage-in the epidemic that is observed in many countries and even in large cities is due to uniform distribution of infected people not being reached yet, and non-uniform distribution of susceptible people, and also parameters $a_{s}, a_{i}, \alpha_{d 1}$, и $\alpha_{d 2}$ being dependent on time and coordinates (see the next section).

The considered example (Figure 6) has a certain peculiarity that is a decrease in a number of infected people in the center, despite $\frac{\alpha_{d 1}}{\alpha_{d 2}}>1$. To explain this phenomenon, let us consider an approximation that allows obtaining an analytical solution.

At an initial stage in an epidemic, just as it is the case with COVID-19, we can assume that density of susceptible people changes only 

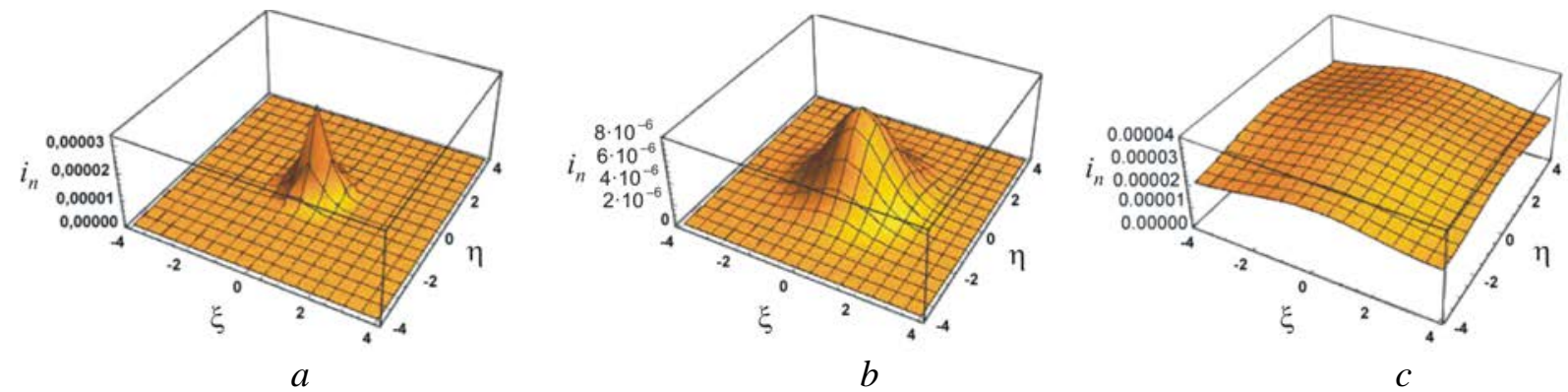

Figure 6. Epidemic development in a square area $16 \times 16$ at $\frac{a_{i}}{a_{s}}=1, \alpha_{d 1}=0.22$, and $\alpha_{d 2}=0.048$ : spatial distribution of infected people: a) at $\tau=0.1$; b) at $\tau=0.5$ and c) at $\tau=5$

slightly and does not depend on coordinates, i.e. $S_{n}=$ const $=1$. In this case, spread of a disease is described with a solution to the following equation:

$$
\frac{\partial i_{n}}{\partial t}=a_{i}\left(\frac{\partial^{2} i_{n}}{\partial x^{2}}+\frac{\partial^{2} i_{n}}{\partial y^{2}}\right)+\left(\alpha_{d 1}-\alpha_{d 2}\right) i_{n}
$$

If

$$
\text { we }
$$

replace $i_{n}=\tilde{i}_{n}(t, x, y) \exp \left[\left(\alpha_{d 1}-\alpha_{d 2}\right) t\right]$ to solve the equation (12), we get a new equation for $\tilde{i}_{n}(t, x, y)$

$$
\frac{\partial \tilde{i}_{n}}{\partial t}=a_{i}\left(\frac{\partial^{2} \tilde{i}_{n}}{\partial x^{2}}+\frac{\partial^{2} \tilde{i}_{n}}{\partial y^{2}}\right)
$$

Analytical solutions for the equation (13), depending on boundary conditions type, a shape of a boundary, and initial conditions, are given, for example, in a Handbook on linear equations in mathematical physics ${ }^{1}$. At an initial stage in an epidemic infected people are close to the first infected ones, and in this case we can use an approximation for an infinite range $\{-\infty<x<\infty ;-\infty<y<\infty\}$ and assume that at an initial moment of time $t=0$ infected people are uniformly distributed in an area given as $\left\{-x_{0}<x<x_{0} ;-y_{0}<y<y_{0}\right\}$. The initial distribution is

$i_{n}(0, x, y)=\left\{\begin{array}{cc}i_{n 0} & \text { at }|x|<x_{0} \text { and }|y|<y_{0}, \\ 0 & \text { at }|x| \geq x_{0} \text { and }|y| \geq y_{0} .\end{array}\right.$

The solution to equation (12)

$$
\begin{gathered}
i_{n}(t, x, y)= \\
=\frac{i_{n 0}}{4}\left[\operatorname{erf}\left(\frac{x_{0}-x}{2 \sqrt{a_{i} t}}\right)+\operatorname{erf}\left(\frac{x_{0}+x}{2 \sqrt{a_{i} t}}\right)\right] \\
{\left[\operatorname{erf}\left(\frac{y_{0}-y}{2 \sqrt{a_{i} t}}\right)+\operatorname{erf}\left(\frac{y_{0}+y}{2 \sqrt{a_{i} t}}\right)\right]} \\
\exp \left[\left(\alpha_{d 1}-\alpha_{d 2}\right) t\right]
\end{gathered}
$$

where $\operatorname{erf}(x)$ is the probability integral. Let us note that analytical solutions are more complicated for other initial and boundary conditions, however, their qualitative behavior is similar.

Integrating (14) over the whole area, we obtain time dependence for the total number of infected people

$$
i(t)=4 i_{n 0} x_{0} y_{0} e^{\left(\alpha_{d 1}-\alpha_{d 2}\right) t}
$$

Accounting that $4 i_{n 0} x_{0} y_{0}=i_{0}$ is the normalized initial number of infected people and comparing solutions to (6) and (15), we can conclude that $\alpha_{d 1}=\alpha_{1}$ and $\alpha_{d 2}=\alpha_{2}$; these parameters and their dependence on time can be estimated with the SIR model. As well within the SIR model, an epidemic ends up at $\alpha_{1}<\alpha_{2}$, although a disease spreads across the considered area and occurs in new districts.

When performing qualitative analysis, we take $y_{0}=x_{0}$ and in the center of the area $\{x=0 ; y=0\}$ density of the infected people is

$$
i_{n}(t, 0,0)=i_{n 0} e r f\left(\frac{x_{0}}{2 \sqrt{a_{i} t}}\right)^{2} \exp \left[\left(\alpha_{1}-\alpha_{2}\right) t\right]
$$

\footnotetext{
${ }^{1}$ Polyanin A.D. Handbook on linear equations in mathematical physics. Moscow, Phizmatlit Publ., 2001, 576 p. (in Russian).
} 
In expression (16) erf decreases with time, and exp grows. It is convenient to replace $t$ with $\tilde{t}=\frac{4 a_{i}}{x_{0}^{2}} t$, then dependence of infected people density in the area center is characterized with just one parameter $\gamma=\frac{x_{0}^{2}}{4 a_{i}}\left(\alpha_{1}-\alpha_{2}\right)$ :

$$
i_{n}(t, 0,0)=i_{n 0} \operatorname{erf}\left(\frac{1}{\sqrt{\tilde{t}}}\right)^{2} \exp [\gamma \tilde{t}] .
$$

Depending on $\gamma$ value, two scenarios are possible (Figure 7): the first is a monotonous growth with time $(\gamma=0.7)$ and the second one is a slight growth in $i_{n}(t, 0,0)$, and then a decrease with time $(\gamma=0.1)$. These scenarios are divided by $\gamma \approx 0.52$. The-first scenario can become a reality when an epidemic starts in a densely populated area (the beginning of COVID-19 epidemic in China); the second, when a disease is brought into a country and starts from an airport, railway station, etc. At any $\gamma$ values and longtime intervals $i_{n}(t, 0,0)$ grows proportionate to $\frac{1}{t} \exp \left[\left(\alpha_{1}-\alpha_{2}\right) t\right]$. This analysis provides a qualitative description of the numeric results given in Figure 7.

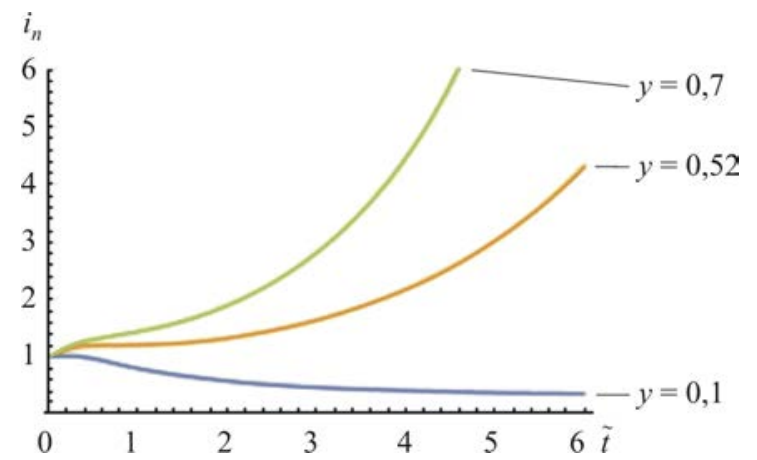

Figure 7. Initial stage of an epidemic: time dependence of a number of infected people in the center of contagion

It is convenient to analyze how a disease spreads in an assumed axially symmetrical spread. On one hand, spread of a disease is close to axially symmetrical one in certain regions and cities. At an initial stage it is so even is a square area (Figure 8). On the other hand, such an approximation being considered allows illustrating the results more clearly. The equations (8) and (9) are rewritten as

$$
\begin{gathered}
\frac{\partial s_{n}}{\partial t}=a_{s} \frac{\partial}{\partial \rho}\left(\rho \frac{\partial s_{n}}{\partial \rho}\right)-\alpha_{1} s_{n} i_{n} \\
\frac{\partial i_{n}}{\partial t}=a_{i} \frac{\partial}{\partial \rho}\left(\rho \frac{\partial i_{n}}{\partial \rho}\right)+\alpha_{1} s_{n} i_{n}-\alpha_{2} i_{n}
\end{gathered}
$$

with boundary

$$
\begin{aligned}
& \left.\frac{\partial i_{n}}{\partial \rho}\right|_{\rho=0}=0 ;\left.\frac{\partial i_{n}}{\partial \rho}\right|_{\rho=\rho_{m}}=0 ; \\
& \left.\frac{\partial s_{n}}{\partial \rho}\right|_{\rho=0}=0 ;\left.\frac{\partial s_{n}}{\partial \rho}\right|_{\rho=\rho_{m}}=0 ;
\end{aligned}
$$

and initial

$$
\begin{gathered}
S_{n}(0, \rho)=1 ; \\
i_{n}(0, \rho)=0.04 \operatorname{Exp}\left[-\rho^{2} / 0.01\right]
\end{gathered}
$$

conditions.

Here $\rho=\sqrt{x^{2}+y^{2}}, \quad \rho_{m}$ is the external boundary radius for the considered area; it is assumed that there are no people moving into and out of it; numeric parameters 0.04 and 0.01 in initial conditions for $i_{n}(20)$ correspond to an initial number of infected people equal to $10^{-6}$ from the total population in the area. Results of simulation of spatio-temporal epidemic development are presented in Figure 8.

For each radius the time dependences of numbers of susceptible and infected people are similar to these presented in Figure 1. However, the maximum number of infected and time necessary to reach it, just like in SIR model, depend on $\alpha_{1}, \alpha_{2}$ and their ratio as well as on a radius, values of parameters $a_{1}$ and $a_{2}$ (please, compare Figures $8 \mathrm{~b}$ and $8 \mathrm{c}$ ), as well as their ratio (please, compare Figures $8 \mathrm{a}$ and $8 \mathrm{~b}$ ). The same time dependence exists for integral characteristics, the total numbers of susceptible, infected and recovered people in the whole area (Figure 9).

Despite susceptible people are distributed uniformly at an initial time, the maximum density of infected people decreases as a distance from the diseases focus grows (Figure 8, 10a). However, a number of infected people per a unit of a radius length $i_{n r}(t, \rho)=2 \pi \rho i_{n}(t, \rho)$ is 


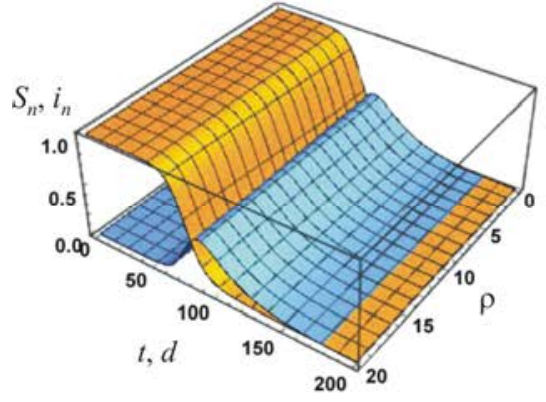

$a$

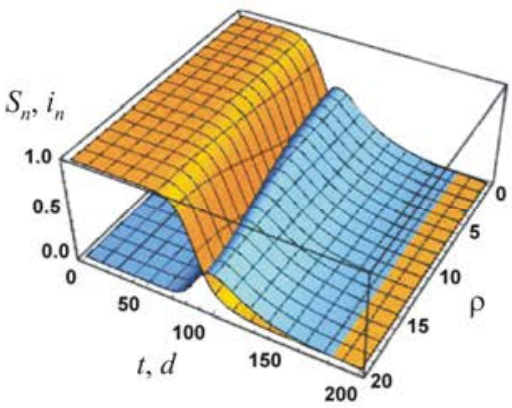

$b$

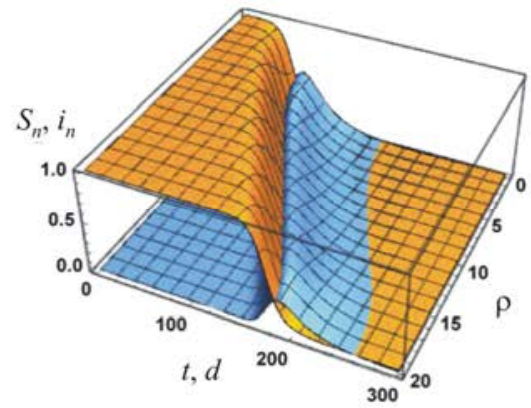

$C$

Figure 8. Spatio-temporal epidemic development; yellow color shows normalized density of susceptible people $s_{n}$, blue color - infected $i_{n}$ : a) $a_{s}=1$ and $a_{i}=1$; b) $a_{s}=1$ and $a_{i}=0.3$; c) $a_{s}=0.1$ and $a_{i}=0.03$. In all cases $\alpha_{1}=0.22, \alpha_{2}=0.048$ and $\rho_{m}=20 ; a_{s}$ and $a_{i}$ are values normalized by the actual (dimension) coefficient of the susceptible people mobility $\lambda$ for the case a), and distance $\rho$ is given in units $\sqrt{\lambda}$

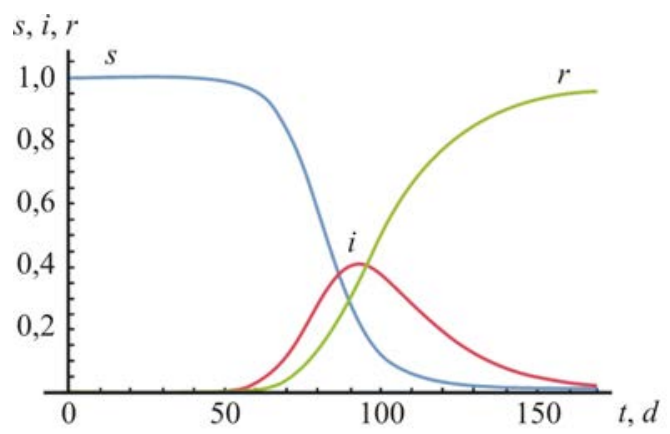

Figure 9. Dependence for a number of susceptible, infected, and recovered people in the whole area.

Parameters are taken just as for Figure 8b, distribution of recovered people was determined by solution to equation of a type (17), in which the last member to the right in it being replaced by $+\alpha_{2} i_{n}$, with zero initial conditions

increasing with a distance from the center (Figure 10b). Therefore, at the same social conditions (population density, mobility of susceptible and infected people, the same parameters that characterize infection and recovery rates) and in spite of active migration to the center, number of infected people will be substantially higher at the periphery than at the center.

The higher density of infected people at the center is caused by the following: at the beginning of an epidemic density of susceptible $(\rho \leq 1)$ close to a disease focus goes down due to their moving into «infected» group. At the same time this density practically stays the same in remote areas where infection has not yet occurred. Within the model this situation
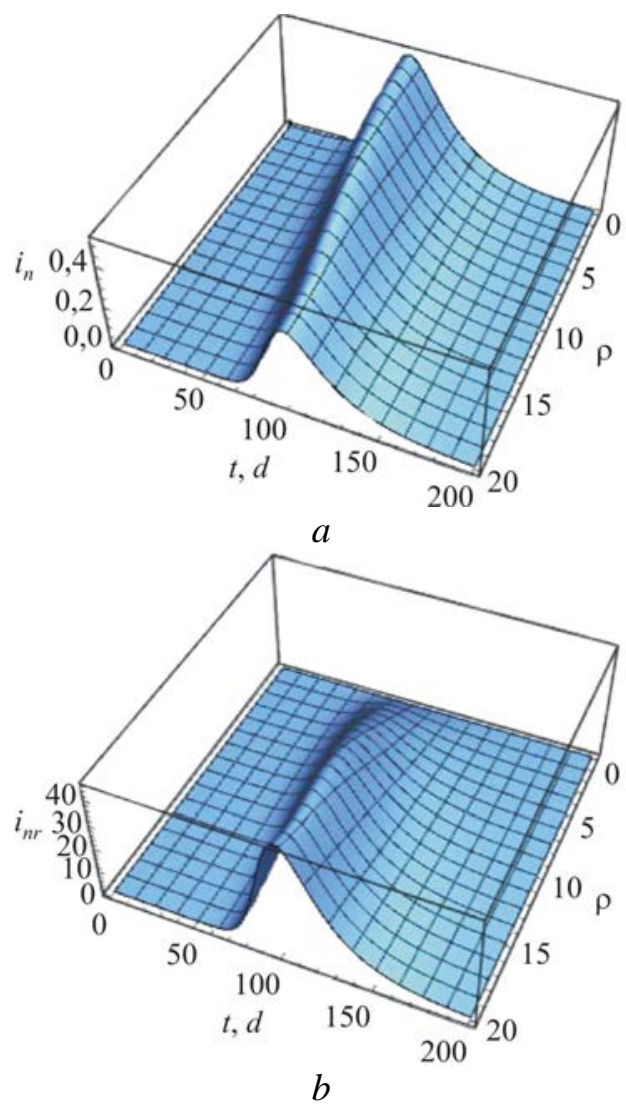

Figure 10. Density of infected people a) and a number of infected ones per a unit of a radius length $b$ ) for the case shown in Figure 8b

results in susceptible people moving to the center. For the case shown in Figure $7 b$, in an area limited by $\rho=1$, and for 200 days ( $t=200$ days) $\sim 1,1 N /\left(\pi \rho_{m}^{2}\right) \quad-$ susceptible people migrate more than $1 / 3$ initially being 
there $\pi N /\left(\pi \rho_{m}^{2}\right)$; for the case shown in Figure $7 \mathrm{~b}$, a number of migrated people is several times higher than $\pi N /\left(\pi \rho_{m}^{2}\right)$. A model based on equations (8) and (9) can be applied only with certain limitations for describing spread of a disease in case susceptible people are distributed non-uniformly. Even in case there is no disease, the solution to equation (8) describes reaching uniform distribution of susceptible people regardless of their initial distribution.

3. Heterogeneous reaction-diffusion epidemiologic model. Population migration can be divided into two types: long-distance travels to other cities, regions, or countries and every day trips (home-work, studies, shopping, etc.). The first type involves a disease being carried over long distances and it is random in its nature. Such spread of a disease can be prevented by imposing limitations on such travels (limited and/or cancelled flights, closing a country completely, etc.), as well as via introducing sanitary-epidemic measures: preliminary diagnostics and quarantine after arrival in a country. These measures were taken in Israel and some other countries at the beginning of COVID-19 epidemic. In countries with large territories (Russia, China, Canada, and the USA) such measures are to be taken in specific regions and areas.

Daily migration occurs within a settlement, in case of a megacity including its satellites (for example, Moscow, Tel-Aviv, or New-York). In the morning people flows go into downtown with high population density; the situation is inverse in the evening. The characteristic epidemiologic times $1 / \alpha_{1}$ and $1 / \alpha_{2}$ are significantly longer than a characteristic time of daily migration that is equal to approximately half a day. It allows introducing averaged density of susceptible people as

$$
\tilde{s}_{n}(t, r)=s_{n}(t, r)+\Delta s_{n}(t, r) / 2
$$

where $s_{n}(t, r)$ is the density of people who permanently live in a given district, and $\Delta s_{n}(t, r)$ is the density of migrating people. The latter value can be both positive for down- town and negative for periphery. At an initial time of an epidemic

$$
\int_{\Omega}\left[s_{n}(0, r)+\Delta s_{n}(0, r)\right] d \Omega=N
$$

where $\Omega$ is the square of the considered area. Further we assume that density of susceptible people changes only due to their moving into the infected group. Equations (8) and (9) are given as follows

$$
\frac{\partial \tilde{s}_{n}}{\partial t}=-\alpha_{1} \tilde{s}_{n} i_{n}
$$

$\frac{\partial i_{n}}{\partial t}=\frac{\partial}{\partial x}\left(a_{i x} \frac{\partial i_{n}}{\partial x}\right)+\frac{\partial}{\partial y}\left(a_{i y} \frac{\partial i_{n}}{\partial y}\right)+\alpha_{1} \tilde{s}_{n} i_{n}-\alpha_{2} i_{n}$

and coefficients $\alpha_{1}, \alpha_{2}, a_{i x}$, and $a_{i y}$ depend on time and coordinates, and coefficients $a_{i x}$ and $a_{i y}$ that characterize mobility of infected people generally depend also on a direction. Let us note that if susceptible people are assumed to be immobile, coefficients $a_{i x}$ and $a_{i y}$ rather characterize local spread of a disease and not mobility of an infected people.

3.1. Influence exerted by lockdown on spatio-temporal spread of a disease. Both the local and integral maximum numbers of infected people account of dozens per cent of population (Figures 1, 8, and 9). In order to decrease a number of infected and dead people as well as to prevent medical aid collapse, limitations and lockdowns are introduced, when a share of infected people is still insignificant, and we can assume that $\tilde{s}_{n}$ depends only on implemented limitations and any changes in it due to contagion are negligible. In this case changes in $\tilde{s}_{n}$ are due to changes in $\Delta s_{n}(t, \rho)$, caused by limitations or lockdown. We will assume that coefficients $\alpha_{1}, a_{i x}=a_{i y}$ depend only on time, $s_{n}(t, \rho)=1$ and parameter $\alpha_{2}$, that characterizes the recovery rate is constant. For the axially symmetrical approximation within the introduced assumptions, epidemic development is described with a solution to the equation

$$
\begin{aligned}
& \frac{\partial i_{n}}{\partial t}=a_{i}(t) \frac{\partial}{\partial \rho}\left(\rho \frac{\partial i_{n}}{\partial \rho}\right)+ \\
& +\alpha_{1}(t, \rho) \tilde{s}_{n}(t, \rho) i_{n}-\alpha_{2} i_{n}
\end{aligned}
$$


with boundary (19) and initial (20) conditions.

Lockdown introduction leads to lower population mobility, regarding both susceptible and infected people, as well as their meetings and, consequently, contagion among susceptible being less probable. To demonstrate lockdown efficiency, we assume that:

- lockdown is introduced at $t=25$ days, the total number of infected people is approximately $0.06 \%$ (the first lockdown was introduced in Israel when a number of infected people was approximately $0.1 \%$ ) and is canceled at $t=55$ days;

- after lockdown is canceled, all model parameters return to their initial values;

- efficient distribution of susceptible people density $\tilde{s}_{n}$ is given as

$$
\tilde{s}_{n}=\frac{b(t) \exp \left[b(t) \rho_{m}^{2}\right]}{\exp \left[b(t) \rho_{m}^{2}\right]-1} \rho_{m}^{2} \exp \left[-b(t) \rho^{2}\right]
$$

- lockdown is characterized with a decrease in parameters $a_{i}$ from 0.3 to 0.1 ; $\alpha_{1}$ from 0.22 to 0.02 and $b \rho_{m}^{2}$ from 0.693 to 0.1054 (dependence of susceptible density on a radius prior to and during a lockdown is shown in Figure 11);

- as it was above, $\alpha_{2}=0.048$ and $\rho_{m}=20$.

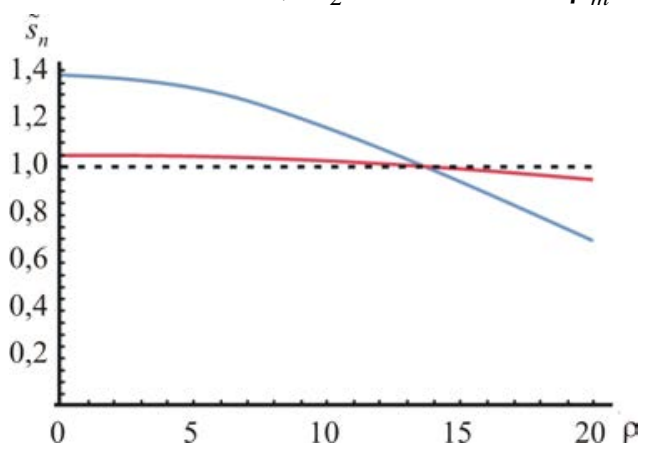

Figure 11. Dependence of susceptible people density on a radius prior to (blue curve) and during lockdown (red curve); green dotted line corresponds to even distribution

Computation results are presented in Figure 12.

In the considered range density of infected people does not exceed $2 \%$ of the population density; it justifies our assumption that changes in density of susceptible people can be neglected. For each radius time dependence for density of infected people is qualitatively similar to the same dependence for the total number of infected ones (Figure 5). There is a growth in a number of infected people that is close to exponential prior to lockdown introduction, a decrease in a number of infected people during lockdown and a drastic rise after lockdown has been canceled and population got back to normal life (a wave-like epidemic). However, at $\rho>15$ density of infected people, both prior to and during lockdown, is finite but also negligible, approximately $10^{-6}$, it can be lower than a single infected person per one unit area. It indicates that lockdown introduction in the area $\rho>15$ is an excessive measure that does unjustified damage. Spread of a disease in this area is a drawback typical for models based on solving equations similar to heat conductivity ones: a paradox of an infinite rate at which heat spreads; when it comes down to an epidemic, it is a paradox related to an infinite disease spread rate.

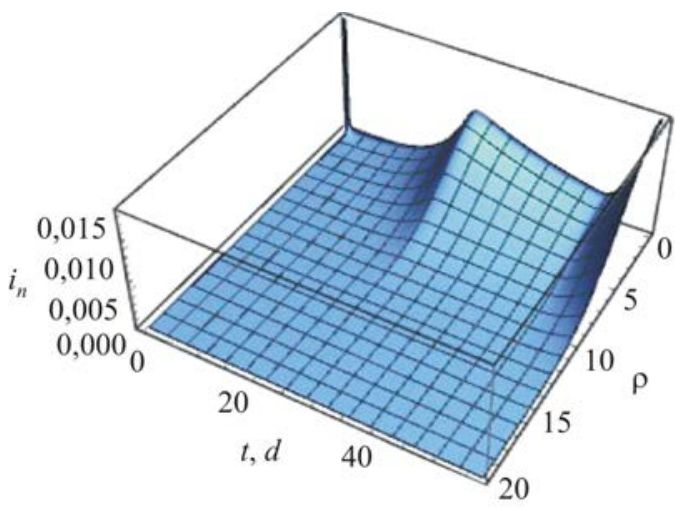

Figure 12. Spatio-temporal distribution of infected

4. Reaction-diffusion epidemiologic model with finite contagion time. In the previous sections we applied parabolic equations to describe spatio-temporal spread of a disease; these equations have a physically paradoxical property, namely infinite rate at which disturbance spreads $[24,25]$. When it comes down to epidemiologic models, it means that a disease spreads instantly: at an area boundary at $\rho=20$ a reaction-diffusion model instantly gives insignificant but still finite density of infected people. It results from a non-apparent assumption that infection spreads from infected to susceptible persons immediately thus making the latter move into the «Infected» category. In actual conditions a disease process is more complicated and can consist of at least two stages: incubation (an infected person is not a source of contagion 
during a part of this period and has no apparent clinical signs of a disease) and a disease itself. SEIR model (Susceptible-Exposed-InfectedRemoved model) allows taking incubation into account $[9,10,17,20]$. Three states considered within the SIR model are added with one more state, Exposed or infected in their incubation period. To introduce this state into the system of equations (8)-(9) we should add one more nonlinear parabolic equation. However, this approach does not solve an issue related to infinite disease spread rate. To resolve the issue, we suggest using Cattaneo-Vernotte model [24, 25] that leads to a finite spread rate. Within the model relaxation (delay) time $\tau_{\text {rel }}$ is introduced and in general case the system of equations (8)-(9) can be represented as

$$
\begin{gathered}
\frac{\partial s_{n}}{\partial t}=\frac{\partial}{\partial x}\left(a_{s x} \frac{\partial s_{n}}{\partial x}\right)+ \\
+\frac{\partial}{\partial y}\left(a_{s y} \frac{\partial s_{n}}{\partial y}\right)-\alpha_{d 1} s_{n} i_{n} \\
\tau_{r e l} \frac{\partial^{2} i_{n}}{\partial t^{2}}+\frac{\partial i_{n}}{\partial t}=\frac{\partial}{\partial x}\left(a_{i x} \frac{\partial i_{n}}{\partial x}\right)+ \\
+\frac{\partial}{\partial y}\left(a_{i y} \frac{\partial i_{n}}{\partial y}\right)+\alpha_{d 1} s_{n} i_{n}-\alpha_{d 2} i_{n}
\end{gathered}
$$

with its parameters depending on time and coordinates.

Equation (27) is a hyperbolic one that's allows obtaining a finite rate of disturbance spread and is widely used for solving heat and diffusion tasks [24, 25]. This equation contains the second time derivative; to find numerical solution it is necessary to set an additional initial condition to all mentioned above. Relaxation time $\tau_{\text {rel }}$ is a characteristic showing the process disequilibrium and it takes into account flow inertia; in our case it is a delay (inertia) in contagion. At an initial moment of time we can consider that

$$
\left.\frac{\partial i_{n}(t, x, y)}{\partial t}\right|_{t=0}=0
$$

Solution to the system of the equations (26) and (27) in axially symmetry is given in Figure 13.

The solution is similar to computations obtained for the model based on parabolic equations (17) and (18) (Figure 8). However, when a delay in contagion is taken into account, it leads to slower disease spread and a front of a disease spread occurs, that is, a moving frontier between an area where there are infected people and an area where such people are absent. Density of infected people goes down to zero smoothly as this frontier is getting closer and $i_{n}=0$ beyond it. This is the principal difference between two solutions; it is shown in Figure 14.

A decrease in $\tau_{\text {rel }}$ approximates solution to the equations (26) and (27) to computations made for equations (17) and (18). However, there is a frontier even for small $\tau_{\text {rel }}$ values: at $\rho_{b} \approx 12$ for $\tau_{r e l}=1$ and $\rho_{b} \approx 15$ for $\tau_{\text {rel }}=0.1$. Predicting how this frontier is going to move allows scientific substantiation for gradual lockdown introduction.

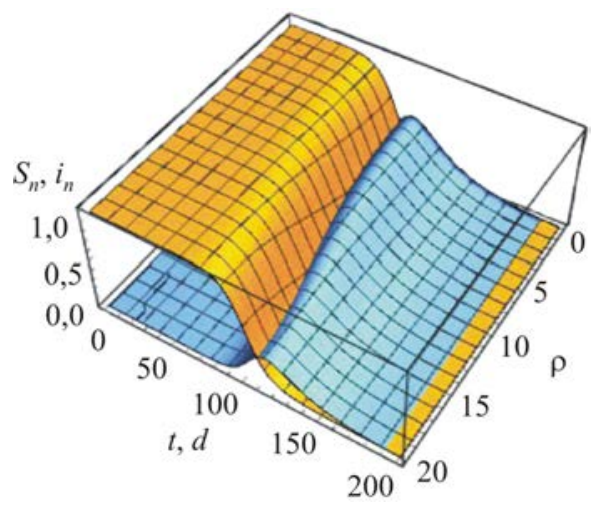

Figure 13. Simulating an epidemic taking into account finite contagion period. Initial and boundary conditions are taken from (19), (20), and (28); the parameters were taken as constant: $a_{s}=1, a_{i}=0.3, \alpha_{1}=0.22, \alpha_{2}=0.048$, and $\tau_{\text {rel }}=1$

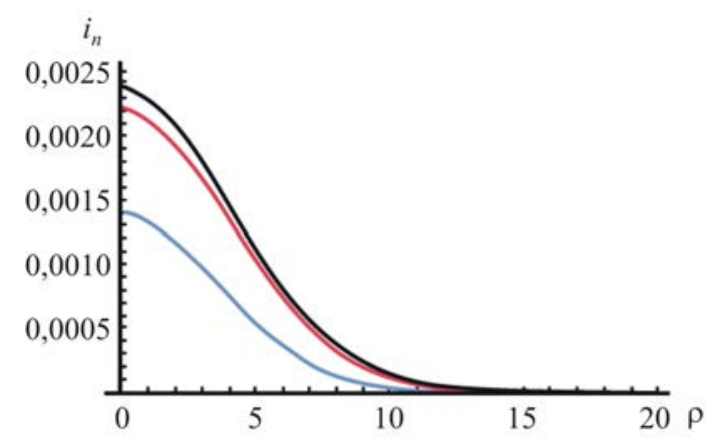

Figure 14. Spatial distribution of infected people at $t=30$ : blue curve means $\tau_{\text {rel }}=1$;

red curve, $\tau_{r e l}=0.1$; black curve, $\tau_{r e l}=0$ (solution that does not take delay into account) 
Conclusion. In this work we have analyzed spatio-temporal epidemic development and influence exerted by lockdown introduction on spread of a disease. Discussed reaction-diffusion epidemiologic models allow taking into account non-uniform population distribution, changes in population mobility and frequency of contacts between susceptible and infected people due to quarantine measures. It was shown that parameters that characterized infection and recovery rates could be estimated with simpler models belonging to SIR type. A reaction-diffusion model that has been modified in this work allows taking into account daily migration of population and its dependence on time.

We suggested a spatio-temporal model in this work that took into account a delay in contagion (incubation period when an infected person is not a contagion source); the model revealed a possibility that the front of a disease spread might occur.

Model parameters depend on a country; in countries with large territories, on their part; they can be different in different districts in a megacity. These parameters depend on many factors such as population density, population mobility, age groups, an extent to which population is involved into occupational activities, and types of these activities. Correct assessment of these parameters depends on statistic data being complete and reliable, that is correct diagnostics, proper accounting of infected people, etc. Thus, statistics ranks only those among infected people who applied for medical aid to medical organizations and had the diagnosis confirmed by medical experts. Statistical data do not cover infection carriers, patients without any symptoms and patients with a disease in its mild form who didn't apply for medical aid. A study that focused on antibodies occurrence revealed that a number of such infected people who spread a disease could be several times higher than it is stated by official statistics [16, 26].
Efficiency of personal protective equipment (face masks and gloves) and quarantine measures to a great extent depends on how disciplined people are; and variations in model parameters that occur due to limitation being introduced can change considerably over time and depend on a location.

Correct prediction of an epidemic development becomes more vital at the moment due to new and more contagious COVID-19 virus strains occurring in England, the SAR, and some other countries.

Just as this work was being accomplished and prepared for publication, a number of infected people grew and new limitations were introduced in some countries. However, an assumption used in this paper that a number of susceptible people and their density have changed only slightly is still valid.

In December 2020 vaccination started in several countries. As the equation (2) shows, vaccination will be successful when $R_{0} s(t)<1$ is reached, that is, a share of insusceptible people (recovered and vaccinated) is higher than $\left(1-1 / R_{0}\right) \cdot 100 \%$. At $R_{0}=4.5$ the threshold amounts to $78 \%$. In case insusceptible people account for such a share of population, any occurred disease focus will end up without taking any quarantine measures. Quarantine measure introduction and adherence to them results in a decrease in $R_{0}$ and a minimum number of vaccinated necessary for an epidemic to stop. However, cancellation of such measures and a local occurred disease focus will lead to a new epidemic wave.

Funding. This research was supported by the joint grant from the Ministry of Science \& Technology (MOST, № 3-16500), Israel \& Russian Foundation (RFBR, № 19-515-06001).

Conflict of interest. The authors declare there is no any conflict of interests.

\section{References}

1. Mallapaty S. Why COVID outbreaks look set to worsen this winter. Nature, 2020, no. 586, pp. 653 . DOI: 10.1038/d41586-020-02972-4

2. Berrai I.E., Bouyaghroumni J., Namir A. Numerical simulation of spatio-temporal model: case of SIR epidemic model. International Journal of Computer Science Issue, 2014, vol. 11, no. 2, pp. 105-108.

3. Capasso V. Mathematical Structures of Epidemic Systems. Berlin, Springer Publ., 1993, 283 p.

4. Brauer F., Van den Driessche P., Wu J. Mathematical Epidemiology. Berlin, Springer Publ., 2008, 408 p.

5. Bashabsheh M.M., Maslinkov B.I. Simulation modeling of the spatial spread of epidemics (cholera for example) using the method of cellular automatalusing the Anylogic. Internet-zhurnal «Naukovedenie», 2013, no. 6, pp. 1-13 (in Russian).

6. Brauer F., Castillo-Chavez C., Feng Z. Mathematical Models in Epidemiology. Berlin, Springer Science+Business Media Publ., 2019, 619 p. 
7. Al-Showaikh F.N.M., Twizell E.H. One-dimensional measles dynamics. Applied Mathematics and Computation, 2004, vol. 152, no. 1, pp. 169-194. DOI: 10.1016/S0096-3003(03)00554-X

8. Al-Raeei M. The basic reproduction number of new coronavirus pandemic with mortality for India, the Syrian Arab Republic, the United States, Yemen, China, France, Nigeria and Russia with different rate of cases. Clinical Epidemiology and Global Health, 2020, vol. 9, pp. 147-149. DOI: 10.1016/j.cegh.2020.08.005

9. Matveev A.V. The mathematical modeling of the effective measures against the COVID-19 spread. Natsional'naya bezopasnost' i strategicheskoe planirovanie, 2020, vol. 29, no. 1, pp. 23-39 (in Russian).

10. Linka K., Peirlinck M., Kuhl E. The reproduction number of COVID-19 and its correlation with public health interventions. Computation Mathematics, 2020, vol. 7, pp. 1035-1050. DOI: 10.1101/2020.05.01.20088047

11. Ejigu B.A., Asfaw M.D., Cavalerie L., Abebaw T., Nanyingi M., Baylis M. Assessing the impact of non-pharmaceutical interventions (NPI) on the dynamics of COVID-19: A mathematical modelling study in the case of Ethiopia. medRxiv, 2020, 30 p. DOI: 10.1101/2020.11.16.20231746

12. Gross B., Zheng Z., Liu S., Chen X., Sela A., Li J., Li D., Havlin S. Spatio-temporal propagation of COVID-19 pandemics. medRxiv, 2020, vol. 9, 6 p. DOI: 10.1101/2020.03.23.20041517

13. Kapoor A., Ben X., Liu L., Perozzi B., Barnes M., Blais M., O'Banion S. Examining COVID-19 Forecasting using Spatio-Temporal Graph Neural Networks. arXiv, 2020, vol. 6, pp. 031133.

14. Yesilkanat C.M. Spatio-temporal estimation of the daily cases of COVID-19 in worldwide using random forest machine learning algorithm. Chaos, Solitons and Fractals, 2020, vol. 140, pp. 110210. DOI: 10.1016/j.chaos.2020.110210

15. Jia J.S., Lu X., Yuan Y., Xu G., Jia J., Christakis N.A. Population flow drives spatio-temporal distribution of COVID-19 in China. Nature, 2020, vol. 582, pp. 389-394.

16. Last M. The first wave of COVID-19 in Israel-Initial analysis of publicly available data. PLoS ONE, 2020, vol. 15, no. 10, pp. 1-16. DOI: 10.1371/journal.pone.0240393

17. Bacaer N. A mathematical model of the beginning of the coronavirus epidemic in France. Mathematical Modelling of Natural Phenomena, 2020, vol. 15, pp. 1-10. DOI: 10.1051/mmnp/2020015

18. Coronavirus Cases. Israel. Worldometers. Available at: https://www.worldometers.info/coronavirus/country/israel/ (12.12.2020).

19. Aschwanden C. The false promise of herd immunity. Nature, 2020, vol. 587, no. 7832, pp. 26-28. DOI: $10.1038 / \mathrm{d} 41586-020-02948-4$

20. Yagiz S., Mori J., Miehling E., Basar T., Smith R.L., West M., Mehta P.G. A data-informed approach for analysis, validation, and identification of COVID 19 models. medRxiv, 2020, vol. 6, 8 p. DOI: 10.1101/2020.10.03.20206250

21. Paul S.K., Jana S., Bhaumik P. On nonlinear incidence rate of COVID-19. medRxiv, 2020, vol. 21, 11 p. DOI: $10.1101 / 2020.10 .19 .20215665$

22. Ahmed N., Wei Z., Baleanu D., Rafid M., Rehman M.A. Spatio-temporal numerical modeling of reaction-diffusion measles epidemic system. Chaos: An Interdisciplinary Journal of Nonlinear Science, 2019, vol. 29, no. 10, pp. 103101. DOI: 10.1063/1.5116807

23. Hou X., Gao S., Li Q., Kang Y., Chen N., Chen K., Rao J., Ellenberg J.S., Patz J.A. Intra-county modeling of COVID-19 infection with human mobility: assessing spatial heterogeneity with business traffic, age and race. medRxiv, 2020, vol. 6, 17 p. DOI: 10.1101/2020.10.04.20206/63

24. Polyanin A.D., Vyaz'min A.V. Uravneniya teploprovodnosti i diffuzii s konechnym vremenem relaksatsii. Postanovki zadachi nekotorye resheniya [Heat conduction and diffusion equation with finite relaxation time. Problem definitions and certain solutions]. Izvestiya vysshikh uchebnykh zavedenii. Seriya: Khimiya i khimicheskaya tekhnologiya, 2013, vol. 56, no. 9, pp. 102-108 (in Russian).

25. Sobolev S.L. Transport processes and traveling waves in systems with local nonequilibrium. Soviet Physics Uspekhi, 1991, vol. 3, no. 34, pp. 217-229.

26. Results of the national serological survey for novel coronavirus. Press Release of the Ministry of Health, Israel, 2020. Available at: https://www.gov.il/en/departments/news/08102020-01 (15.11.2020).

Sokolovsky V.L., Furman G.B., Polyanskaya D.A., Furman E.G. Spatio-temporal modeling of COVID-19 epidemic. Health Risk Analysis, 2021, no. 1, pp. 23-37. DOI: 10.21668/health.risk/2021.1.03.eng

Received: 01.02.2021

Accepted: 16.02.2021

Published: 30.03.2021 
UDC $614.876+614.878$

DOI: $10.21668 /$ health.risk/2021.1.04.eng

Research article

\section{HEALTH RISK ANALYSIS AS PER RADIATION AND CHEMICAL FACTORS IN A ZONE INFLUENCED BY A NUCLEAR LEGACY OBJECT}

\section{S.M. Kiselev, N.K. Shandala, T.N. Lashchenova, Yu.N. Zozul, V.V. Shlygin, T.I. Gimadova, A.N. Malakhova}

State Research Center Burnasyan Federal Medical Biophysical center of Federal Medical Biological Agency, 46 Zhivopisnaya Str., Moscow, 123182, Russian Federation

Rehabilitation programs for nuclear legacy objects in north-western regions in Russia involve decommissioning; a former coast technical support base belonging to the RF Navy and located on the Gremikha peninsula in Murmansk region is now being removed from service. At present spent nuclear fuel is being extracted from ship reactors with liquidmetal coolant and nuclear wastes that have been accumulated during active operations are being treated. The current activities at the site result in complex influence on the environment determined by both radiation and non-radiation contaminants.

The present work focuses on examining a hygienic situation existing in residential areas located close to this nuclear legacy object. In general, radiation situation in residential areas is determined by technogenic contaminants, basically ${ }^{137}$ Cs and ${ }^{90} \mathrm{Sr}$ radionuclides.

Our research has revealed that at the moment their contents in the environmental objects correspond to background levels that are typical for the examined region. Chemical contamination detected in residential areas is characterized with elevated heavy metals contents ( $\mathrm{Cd}, \mathrm{As}, \mathrm{Pb}, \mathrm{V}, \mathrm{Zn}, \mathrm{Cu}$ etc.) in soils in urban settlements that are higher than background levels. We detected lead and zinc concentrations that were higher than MPC. Total soil contamination with heavy metals $(\mathrm{Zc})$ is still «permissible» in most residential areas. Carcinogenic health risk for people living in the examined residential areas does not exceed $10^{-6}$ as per radiation and chemical factors.

Research results allow assessing the current hygienic situation as normal and concluding that decommissioning of SZC «SevRAO» objects (Gremikha section) does not exert negative impacts on the environment and health of people living in residential areas located nearby. The obtained data give grounds for controlling activities when environmental monitoring is accomplished during works aimed at recovering contaminated areas where nuclear legacy objects are located.

Key words: radiation-hazardous objects, nuclear legacy, SZC «SevRAO», Gremikha, carcinogenic risk, technogenic radionuclides, heavy metals, hygienic assessment, population health.

(C) Kiselev S.M., Shandala N.K., Lashchenova T.N., Zozul Yu.N., Shlygin V.V., Gimadova T.I., Malakhova A.N., 2021

Sergey M. Kiselev - Candidate of Biological Sciences, Head of the Laboratory for Regulating Surveillance over Nuclear Legacy Objects (e-mail: sergbio@gmail.com; tel.: +7 (985) 761-10-17; ORCID: https://orcid.org/0000-0002-2613-2293).

Nataliya K. Shandala - Doctor of Medical Sciences, Deputy to Managing Director (e-mail: shandala-fmbc@bk.ru; tel.: +7 (499) 190-93-29; ORCID: https://orcid.org/0000-0003-1290-3082).

Tatiana N. Lashchenova - Doctor of Biological Sciences, v (e-mail: tlaschenova@yandex.ru; tel.: +7 (910) 404-91-10; ORCID: https://orcid.org/0000-0002-6682-1261).

Yuliya N. Zozul - Candidate of Biological Sciences, Researcher (e-mail: julnik@list.ru; tel.: +7 (985) 920-39-83; ORCID: https://orcid.org/0000-0003-3154-1806).

Vladimir V. Shlygin - Junior Researcher (e-mail: vladvas83@mail.ru; tel.: +7 (499) 190-94-18; ORCID: https:// orcid.org/0000-0002-1190-9557).

Tamara I. Gimadova - Senior researcher (e-mail: tamara.gimadova@icloud.com; tel.: +7 (499) 190-96-65; ORCID: https://orcid.org/0000-0001-9144-2610).

Anna N. Malakhova - Engineer (e-mail: lawbro@yandex.ru; tel.: +7 (499) 190-96-65; ORCID: https://orcid.org/00000003-3868-3671). 
According to the Basic Principles of State Policy of the Russian Federation in the Field of Nuclear and Radiation Safety approved by the RF President in $2018^{1}$ a set of activities is now being implemented that are aimed at remediating nuclear legacy sites and facilities. These include civilian and military facilities created before the current nuclear and radiation safety requirements had been approved. Among them, some facilities are at the stage of decommissioning, disposal and burial.

The assessment of the potential anthropogenic impact exerted by nuclear and radiation hazardous facilities on the population and the environment is a socially significant factor and a subject for studying within various research projects, including international ones ${ }^{2}[1-5]$.

The comparative analysis of the potential hazard caused by radiation sources and impact assessment for the population and the environment is based on a risk approach. It is an advanced tool for environmental and public health management [6-9]. The current risk assessment methodology is based on studying and analyzing all the factors affecting the environment and indirectly humans. Risk assessment is also carried out for independent and combined impacts on population and ecosystems. The assessment result provides the basis for subsequent comparative analysis and risk management that significantly optimize the nuclear legacy sites decommissioning and the remediation of their territories [10-14].

This paper presents the health physics assessment of the environment. It also presents a study of the potential impact on the local population by decommissioning the Navy's former shore technical base (hereinafter referred to as STB) located in the northwest of the country (Murmansk region). In 1958, STB was built on the Gremikha peninsula. It was used for the stationing of nuclear submarines, recharging of reactors with water and liquidmetal coolants, carrying out dock inspections and repairs. Since the base was in active operations, substantial quantities of spent nuclear fuel (SNF) and radioactive waste (RW) were being accumulated on its territory. Their total activity is $13 \cdot 10^{15} \mathrm{~Bq}$ [15]. In the late $1980 \mathrm{~s}$ it fell out of use after relocating the nuclear submarines division and removing military personnel from the base. It resulted in the degradation of the base infrastructure and the destruction of engineering barriers around SNF and RW storage facilities, and artificial radionuclides migration into the environment. The facility was taken over by Rosatom Corporation for decommissioning and remediation of contaminated territories. It is necessary to provide safety for the local population and prevent further environmental contamination. The Gremikha division of the North-western Center for Radioactive Wastes Management «SevRAO» (hereinafter NWC «SevRAO» Gremikha) was created at the territories of the former STB. This facility belongs to the Federal State Enterprise for RW management «RosRAO» (it has been called «The Federal Ecologic Operator» since 2020). At present, the main facility operations deal with RW and SNF management during disassembling of spent removable parts of nuclear submarines reactors with liquid-metal coolant and treating of high-level RW stored on an open ground. After removing SNF and RW, it is planned to remediate the contaminated territories according to the «brownfield» scenario. Due to operational specificity, the object belongs to the $1^{\text {st }}$ radiation hazard category. According to it, the site is divided into three zones, namely, an operational zone with controlled access, a health protection zone, and a supervision area. Operators monitor the radiation situation in all three zones following established requirements.

Previous activities at the site and ongoing decommissioning measures dictate the necessity to consider the potential contamina-

\footnotetext{
${ }^{1}$ On approval of the Basics Principles of State Policy in the Field of Nuclear and Radiation safety in the Russian federation for a period up to 2025 and further on: the RF President Order issued on October 13, 2018 No. 585. The RF President. Available at: http://www.kremlin.ru/acts/bank/43631 (10.07.2020) (in Russian).

${ }^{2}$ Assessing the Long Term Safety of Radioactive Waste Management. Regulatory Guide G-320. Ottawa, Ontario, Canadian Nuclear Safety Commission December Publ., 2006, 41 p.
} 
tion of the site and surrounding areas with radioactive and non-radiological contaminants $[16,17]$. Non-radiological contaminants include a wide range of organic and inorganic ones such as heavy metals that can be found in emissions from gas-cutting machinery, welding, painting, and deactivating works performed during implementation of the current remediation activities. Therefore, the main goal of the research was to perform a complex health risk assessment of public exposure to radiation and chemical environmental contaminants living in the vicinity of NWC «SevRAO» Gremikha during decommissioning the nuclear legacy site.

Materials and methods. Measurements, sampling, and sample analysis were performed following the conventional procedures approved by the certified Laboratory Centre at Burnasyan Federal Medical Biophysical Center (Certificate No. RA.RU.21БУ01).

The data were subjected to statistical analysis using generally accepted methods (GOST R ISO 16269-7-2004) ${ }^{3}$. Microsoft Excel was used for calculations. Gamma dose rates were measured using a portable Na-I scintillation detector (MCS-01A «Multirad-M» (NTTs Amplituda, Russia)). Gamma-spectrometric («CANBERRA» gamma-spectrometer with semi-conductor germanium detector, the USA) and radiochemical methods were used to determine artificial radionuclides in environmental media.

Public dose assessment was performed according to the recommendations by the International Commission on Radiological
Protection (ICRP) and the International Atomic Energy Agency (IAEA), taking into account regional background levels ${ }^{4}$ [18]. The average annual effective dose (hereinafter called AAED) was calculated according to the national radiation safety standards $(\mathrm{NRB}-99 / 2009)^{5}$.

AAED of external exposure (both indoors and outdoors) was conservatively assessed by TLD (thermoluminescent dosimetry (TL-dosimeters with lithium-fluoride-based detectors (DTG-4), $1 \mathrm{~g} / \mathrm{cm}^{2}$ ).

Internal exposuredoses due to ingestion pathway were calculated according to Guidelines MR 2.6.1.0063-12 ${ }^{6}$ :

$$
E_{i, k}^{\mathrm{int}}=\sum_{k} \sum_{j}\left(e_{i}^{k} \cdot V_{i, j} \cdot S_{k, j}\right),
$$

$e^{k}, \mathrm{mSv} / \mathrm{Bq}$ is an age- dependent dose coefficient for the $\mathrm{k}$-th radionuclide (ingestion pathway), NRB-99/2009;

$V_{i, j}, \mathrm{~kg} /$ year, is annual consumption of the $\mathrm{j}$-th product (consumed drinking water is $730 \mathrm{~L})$

$S_{k, j}, \mathrm{~Bq} / \mathrm{kg}$, is average annual specific activity of the k-th radionuclide in the $\mathrm{j}$-th food product.

Metals were determined with atomic-absorption spectroscopy («Kvant 2 AT», Russia).

Chemical contamination of soil was evaluated via comparison with $\mathrm{MPC}^{7} / \mathrm{TPC}^{8}$, concentration factor $\left(\mathrm{K}_{\mathrm{c}}\right)$ and cumulative pollution index $\left(\mathrm{Z}_{\mathrm{c}}\right)$ according to the Guidelines MU 2.1.7.730-99 ${ }^{9}$. Concentration factor $K_{c}$ is determined as a ratio between metal concentra-

\footnotetext{
${ }^{3}$ GOST R ISO 16269-7-2004. Statistical procedures. Statistical data presentation. Median. Determination of point estimate and confidence intervals. KODEKS: an electronic fund for legal and reference documentation. Available at: http://docs.cntd.ru/document/1200035332 (10.07.2020) (in Russian).

${ }^{4}$ Radiation Protection and Safety of Radiation Sources: International Basic Safety Standards, IAEA Safety Standards Series No. General Safety Requirements, Part 3. No GSR-3. Vienna, IAEA Publ., 2014, 477 p.

${ }^{5}$ Radiation Safety Standards (NRB-99/2009). Sanitary-epidemiologic rules and standards SER 2.6.1.2523-09. Moscow, The Federal Center for Hygiene and Epidemiology of Rospotrebnadzor Publ., 2009, 100 p. (in Russian).

${ }^{6}$ MR 2.6.1.0063-12. Control over radiation doses received by population living in a zone close to a radiation object, in a situation when it is functioning properly or when there is radiation emergency. KODEKS: an electronic fund for legal and reference documentation. Available at: http://docs.cntd.ru/document/1200095229 (10.07.2020) (in Russian).

${ }^{7}$ HS 2.1.7.2041-06. Maximum permissible concentrations (MPC) of chemicals in soil. KODEKS: an electronic fund for legal and reference documentation. Available at: http://docs.cntd.ru/document/901966754 (10.07. 2020) (in Russian).

${ }^{8}$ HS 2.1.7.2511-09. Tentative permissible concentrations (TPC) of chemicals in soil. KODEKS: an electronic fund for legal and reference documentation. Available at: http://docs.cntd.ru/document/901966754 (10.07.2020) (in Russian).

${ }^{9}$ MU 2.1.7.730-99. Hygienic assessment of soil quality in settlements. KODEKS: an electronic fund for legal and reference documentation. Available at: http://docs.cntd.ru/document/1200003852 (10.07.2020) (in Russian).
} 
tion in examined soil $\left(\mathrm{C}_{\mathrm{i}}\right)$ and regional background values $(\mathrm{mg} / \mathrm{kg})\left(\mathrm{C}_{\mathrm{fi}}\right)$ :

$$
K_{c}=C_{i} / C_{f i}
$$

The cumulative pollution indexis determined as a sum of concentration factors were determined for all chemical contaminants.

$$
Z_{c}=\Sigma\left(K_{c i}+\ldots+K_{c n}\right)-(n-1)
$$

$\mathrm{n}$ is a number of examined metals;

$K_{c i}$ is a concentration factor of the $i$-th component.

Chemical contamination of drinking water was evaluated according to the Requirements 2.1.4.1074-0 $1^{10}$, and Hygienic Standards GN 2.1.5.1315-03 ${ }^{11}$.

Health risk caused by radiation exposure was calculated using a linear risk coefficient for malignant neoplasms for the overall population $\left(5.5 \cdot 10^{-2}\right)$ according to NRB-99/2009. According to the guidelines (Roshydromet R 52.18.787-2013 ${ }^{12}$ ) on the specific content of artificial radionuclides in soil and drinking water, the public risk was evaluated taking into account the basic exposure pathways.

The calculation of public health risks caused by chemical pollutants (heavy metals) was performed in accordance with the guidelines $\mathrm{R} 2 \cdot 1 \cdot 10.1920-04^{13}$. The individual carcinogenic risk was calculated under the permanent residence scenario. The factors of exposure which provide additional individual carcinogenic risk via the dermal, inhalation and ingestion routes of intake were taken into consideration.

Results and discussion. Site characterization. According to the ecological reports
(2017-2019), the NWC «SevRAO» Gremikha does not discharge radionuclides in the environment at the current stage of decommissioning.

At the industrial site there are local areas under surface and depth soil contamination with artificial radionuclides. Gamma dose rate varies within the range of $0.05 \div 150 \mu \mathrm{Sv} /$ hour (median is $0.44 \mu \mathrm{Sv} /$ hour). The main artificial radionuclides detected in the environment (soil, algae, and bottom sediment) are ${ }^{137} \mathrm{Cs}$ and ${ }^{90} \mathrm{Sr}$. There are also trace concentrations of ${ }^{154} \mathrm{Eu}$ (soil) and ${ }^{3} \mathrm{H}$ (subsoil waters). Ground water is contaminated with ${ }^{90} \mathrm{Sr}$ and ${ }^{3} \mathrm{H}$ radionuclides along with heavy metals in concentrations exceeding MPC. Subsoil- and ground water are polluted predominantly with $\mathrm{Cd}$ and $\mathrm{Tl}$, and $\mathrm{Cd}, \mathrm{Ni}, \mathrm{Al}, \mathrm{Mn}$, and $\mathrm{Zn}$ respectively. Chemical contamination of soil is heterogeneous and represented by the wide spectrum of metals, including $\mathrm{Pb}, \mathrm{Ni}, \mathrm{Cu}, \mathrm{Zn}, \mathrm{V}$, $\mathrm{Cd}$, and As [19].

Therefore, the paper focuses on the analysis of soils and drinking water in the residential area in the vicinity of the nuclear legacy site.

A closed settlement, called Ostrovnoy, is located in the supervision area of the industrial site. The settlement includes two districts, Ostrovnoy and Gremikha, located 1-2 km away from the examined site. As of 2019, the population is 1,842 people [20]. They live in multistorey panel and brick houses equipped with centralized water supply. Water supply for drinking and household needs is carried out from the surface lake (Zmei lake) located $4 \mathrm{~km}$ away from the residential area. The terrain in the examined area is highly irregular; there are rocks, multiple lakes, and moors. Due to harsh

\footnotetext{
${ }^{10}$ SER 2.1.4.1074-01. Drinking water. Hygienic requirements to quality of water taken from centralized drinking water supply system. Quality control. Hygienic requirements to providing safety of hot water supply systems. Hygienic assessment of soil quality in settlements. KODEKS: an electronic fund for legal and reference documentation. Available at: http://docs.cntd.ru/document/901798042 (10.07.2020) (in Russian).

${ }^{11}$ GN 2.1.5.1315-03. Maximum permissible concentrations (MPC) of chemicals in water taken from water objects used for drinking and communal water supply. KODEKS: an electronic fund for legal and reference documentation. Available at: http://docs.cntd.ru/document/901862249 (10.07.2020) (in Russian).

${ }^{12} \mathrm{R} 52.18 .787-2013$. The procedure for assessing radiation risks basing of data obtained via radiation situation monitoring. Obninsk, «VNIIGMI-MCD» Publ., 2014, 116 p. (in Russian).

${ }^{13} \mathrm{R} 2.1 .10 .1920-04$. Guide on assessing health risks under exposure to chemicals that pollute the environment. KODEKS: an electronic fund for legal and reference documentation. Available at: http://docs.cntd.ru/document/1200037399 (10.07.2020) (in Russian).
} 
Table 1

Gamma dose rate in the residential and background area

\begin{tabular}{|l|c|c|c|c|}
\hline \multirow{2}{*}{ Territory } & \multirow{2}{*}{$\begin{array}{c}\text { Number } \\
\text { of measurements }\end{array}$} & \multicolumn{3}{|c|}{ Gamma dose rate, $\mu$ Sv/hour } \\
\cline { 3 - 5 } & 131 & Minimum & Maximum & Median \\
\hline Background area & 0.06 & 0.20 & $0.11(0.07-0.15)$ \\
\hline Ostrovnoy district & 6,538 & 0.06 & 0.21 & $0.07(0.05-0.10)$ \\
\hline Gremikha district & 3,224 & 0.05 & 0.16 & $0.07(0.05-0.10)$ \\
\hline
\end{tabular}

Table 2 exceed permissible activity levels estab-

Specific activity of artificial radionuclides in ambient air in Murmansk region in $2019^{16}$

\begin{tabular}{|l|c|c|c|}
\hline \multirow{2}{*}{ Radionuclides } & \multicolumn{3}{|c|}{ Specific activity, $\mathrm{Bq} / \mathrm{m}^{3}$} \\
\cline { 2 - 4 } & Average & Maximum & $\begin{array}{c}\text { Permissible } \\
\text { activity }\end{array}$ \\
\hline${ }^{137} \mathrm{Cs}$ & $7.8 \cdot 10^{-6}$ & $18.8 \cdot 10^{-6}$ & 27 \\
\hline${ }^{90} \mathrm{Sr}$ & $6.3 \cdot 10^{-6}$ & $9.9 \cdot 10^{-6}$ & 2.7 \\
\hline
\end{tabular}

climate and poor soils, basic flora contains only lichen, shrubby birches, and shrubs. Natural and climatic conditions in this area do not allow engaging in agriculture or animal breeding. All the necessary food products and fuel are delivered by sea or by helicopters. People only consume delivered food.

Radiation situation in the supervision area. Gamma dose rate. Gamma dose rate measured in Gremikha and Ostrovnoy districts corresponds to the regional background level (Table 1) typical for the natural background radiation existing in Murmansk region $^{14}(0.06-0.23 \mu \mathrm{Sv} /$ hour $)$.

Artificial radionuclides in environmental media. The dominant artificial radionuclides in the environment are ${ }^{137} \mathrm{Cs}$ and ${ }^{90} \mathrm{Sr}$. According to the data provided by the operator of the site ${ }^{15}$ the ambient air pollution with artificial radionuclides does not lished in NRB-99/2009. It is also confirmed by the data in the Radiation-hygienic profile issued for Murmansk region territory in 2019 (Table 2).

The specific activity of ${ }^{137} \mathrm{Cs}$ and ${ }^{90} \mathrm{Sr}$ in soil corresponds to the regional background values in the residential area (Table 3).Contamination of soil samples with artificial radionuclides taken in the vicinity to the nuclear legacy site corresponds to the requirements established for unlimited use of solid materials $\mathrm{A}_{\mathrm{UU}}$ according to OSPORB-99/2010 ${ }^{17}$.

The water samples of Zmei lake correspond to the requirements established for drinking water quality for the artificial radionuclides. The specific activity of ${ }^{137} \mathrm{Cs}$ and ${ }^{90} \mathrm{Sr}$ is three orders of magnitude lower than the intervention limit regulated by NRB99/2009 (Table 3).

Public doses. According to the project documentation expected AAED for population due to actual emissions should be $16.34 \mu \mathrm{Sv}$ in the normal operation mode. It is significantly lower than the established dose limit of $100 \mu \mathrm{Sv}^{18}$. Ground-level concentrations of contaminants outside the health protection zone were estimated by the qualitative and quantitative composition of emissions into the

\footnotetext{
${ }^{14}$ Radiation situation in Russia and neighboring states in 2018. Annual edition. Obninsk, 2019, 324 p. (in Russian).

${ }^{15}$ There port on ecological safety issued in 2018 by the North-western Center for Radioactive Wastes Management - a branch of the «RosRAO» Federal enterprise responsible for Radioactive Wastes Management, 2018, 32 p. (in Russian).

${ }^{16}$ The radiation-hygienic profile issued for Murmansk region in 2019, 2019, 11 p. (in Russian).

${ }^{17}$ SR 2.6.1.2612-10. Basic sanitary rules for radiation safety provision (OSPORB-99/2010). KODEKS: an electronic fund for legal and reference documentation. Available at: http://docs.cntd.ru/document/902214068 (10.07. 2020) (in Russian).

${ }^{18}$ The project for substantiating boundaries of a sanitary protection zone for the Gremikha division of the North-western Center for Radioactive Wastes Management, 2017, 143 p. (in Russian).
} 
Table 3

The specific activity of artificial radionuclides in soils and water in the lake located nearby Gremikha district

\begin{tabular}{|c|c|c|c|c|c|c|}
\hline \multirow{3}{*}{ Area } & \multicolumn{6}{|c|}{ Specific activity, $\mathrm{Bq} / \mathrm{kg}$} \\
\hline & \multicolumn{3}{|c|}{${ }^{137} \mathrm{Cs}$} & \multicolumn{3}{|c|}{${ }^{90} \mathrm{Sr}$} \\
\hline & Number of mes. & Maximum & Median & Number of mes. & Maximum & Median \\
\hline Soil & \multicolumn{3}{|c|}{$A_{U U}=100$} & \multicolumn{3}{|c|}{$\mathrm{A}_{\mathrm{UU}}=1,000$} \\
\hline Background & 4 & 16 & $8(4-12)$ & 4 & 10 & $0.2(0.2-0.5)$ \\
\hline Ostrovnoy dist. & 8 & 29 & $9(1-13)$ & 5 & 1 & $0.4(0.2-0.9)$ \\
\hline Gremikha dist. & 13 & 31 & $11(1-25)$ & 5 & 0.5 & $0.3(0.2-0.6)$ \\
\hline Water & \multicolumn{3}{|c|}{ Interventional level- 11} & \multicolumn{3}{|c|}{ Interventional level- 4.9} \\
\hline Zmei lake & 2 & 0.003 & 0.003 & 2 & $<0.001$ & $<0.001$ \\
\hline
\end{tabular}

ambient air. They correspond to hygienic requirements SER2.1.6.1032-01 ${ }^{19}$. Therefore, the main exposure pathways are external exposure and internal exposure due to drinking water consumption.

According to TL-dosimeters, external exposure AAED does not exceed $1.63 \mathrm{mSv}$ (Table 4) with its median value by $0.98 \mathrm{mSv}$. External exposure dose inside houses corresponds to its outdoor values.

Considering standard time spent by the population indoors $(6,600$ hours) and outdoors (2,200 hours), the median AAED value for external exposure was $0.85 \mathrm{mSv}$, varying from 0.40 to $1.58 \mathrm{mSv}$.

External exposure to AAED from artificial sources is $10 \mu \mathrm{Sv}$ excluding regional background radiation (natural sources and artificial background radiation from global fallout).
The contribution of artificial radionuclides with drinking water consumption to internal exposure is $0.02 \mu \mathrm{Sv}$.

Total AAED of external and internal exposure from artificial sources is $10 \mu \mathrm{Sv}$ for the population and does not exceed dose limits established by radiation safety standards NRB-99/2009.

Heavy metal contamination of soil and drinking water in the residential area. We've examined the heavy metals in soil samples taken in Ostrovnoy and Gremikha districts and in drinking water samples taken from Zmei lake for elements from all chemical hazard categories.

It was found that the concentrations of metals from the $1^{\text {st }}$ hazard category $(\mathrm{Pb}, \mathrm{As}, \mathrm{Cd}$, and $\mathrm{Zn})$ and he $2^{\text {nd }}$ hazard category $(\mathrm{Ni}, \mathrm{Cu}$, and $\mathrm{Cr}$ ) in soil samples exceed the background values in

Table 4

External exposure AAED near Gremikha district

\begin{tabular}{|l|c|c|c|c|}
\hline \multirow{2}{*}{\multicolumn{1}{|c|}{ Territory }} & \multirow{2}{*}{$\begin{array}{c}\text { Number } \\
\text { of measurements }\end{array}$} & Minimum & Maximum & Median \\
\cline { 3 - 5 } & & & & \\
\hline Background area (Zmei lake) & & 0.40 & 1.40 & $0.97(0.40-1.38)$ \\
\hline - outdoors & 6 & & & $0.98(0.40-1.56)$ \\
\hline Ostrovnoy closed settlement: & & 0.40 & 1.63 & $0.80(0.40-1.30)$ \\
\hline - outdoors & 16 & 0.40 & 1.56 & \multicolumn{2}{c|}{ External exposure AAED, mSv } \\
\hline - inside houses & 6 & & & \\
\hline
\end{tabular}

${ }^{19}$ SER 2.1.6.1032-01. Hygienicrequirementstoprovidingproperambientairqualityinsettlement. KODEKS: an electronic fund for legal and reference documentation. Available at: http://docs.cntd.ru/document/901787814 (10.07. 2020) (in Russian). 
Table 5

The heavy metals in soil in the examined residential area and regional background

\begin{tabular}{|c|c|c|c|c|c|c|c|}
\hline \multirow{2}{*}{ Element } & \multirow{2}{*}{$\begin{array}{l}\text { Chemical haz- } \\
\text { ard category }\end{array}$} & \multicolumn{3}{|c|}{ Heavy metal, $\mathrm{mg} / \mathrm{kg}$} & \multicolumn{2}{|c|}{ Assessment criteria, $\mathrm{mg} / \mathrm{kg}$} & \multirow{2}{*}{$\mathrm{K}_{\mathrm{c}}$} \\
\hline & & Minimum & Maximum & Median & Regional background & MPC/TPC & \\
\hline $\mathrm{Pb}$ & 1 & 35 & 210 & $120(40-190)$ & 18 & 32 & 6 \\
\hline $\mathrm{Cd}$ & 1 & 0.09 & 0.90 & $0.22(0.09-0.63)$ & 0.06 & 0.5 & 3 \\
\hline As & 1 & 0.1 & 1.2 & $0.6(0.1-0.9)$ & 0.3 & 2 & 2 \\
\hline $\mathrm{Zn}$ & 1 & 97 & 980 & $170(101-680)$ & 58 & 110 & 3 \\
\hline $\mathrm{Ni}$ & 2 & 23 & 39 & $34(25-37)$ & 20 & 40 & 2 \\
\hline $\mathrm{Cu}$ & 2 & 15 & 97 & $35(20-78)$ & 12 & 66 & 2 \\
\hline $\mathrm{Cr}$ & 2 & 28 & 120 & $81(31-113)$ & 34 & - & 2 \\
\hline $\mathrm{V}$ & 3 & 47 & 93 & $75(49-83)$ & 48 & 150 & 2 \\
\hline $\mathrm{Mn}$ & 3 & 490 & 610 & $600(502-602)$ & 400 & 1500 & 1 \\
\hline $\mathrm{Ba}$ & 3 & 620 & 790 & $700(630-778)$ & 720 & - & 1 \\
\hline $\mathrm{Sr}$ & 3 & 260 & 300 & $280(265-290)$ & 300 & - & 1 \\
\hline $\mathrm{Zc}$ & & 2 & 28 & $9(2-17)$ & - & - & - \\
\hline
\end{tabular}

soils of this region (Table 5). According to health physics assessment, the $\mathrm{Pb}$ and $\mathrm{Zn}$ concentrations in soils reached up to 7 MPC, 9 TPC, respectively. The soil in the most of the examined areas have a «permissible» contamination level by calculated $\mathrm{Zc}$ index $(\mathrm{Zc}<16)$. The maximum value of $Z c$ is 28 , which characterizes soil contamination as «moderately hazardous». It caused by increased soil concentrations of $\mathrm{Pb}$, $\mathrm{Cd}$, and Zn (Table 5).

Water from the lake contained the following heavy metals in significant concentrations: $\mathrm{Al}(0.011 \pm 0.004 \mathrm{mg} / \mathrm{L}), \mathrm{Fe}(0.03 \pm 0.01 \mathrm{mg} / \mathrm{L})$, and $\mathrm{Mn}(1.0 \pm 0.3 \mathrm{mg} / \mathrm{L})$ without exceeding MPC. We didn't either detect any metals of the $1^{\text {st }}$ chemical hazard category in significant concentrations. Water from the lake corresponds to requirements established for drinking water quality by heavy metals.

Comprehensive analysis of carcinogenic risks for population. The experimental studies on the environmental pollution in the area close to the studied nuclear legacy site formed the basis for carcinogenic risk assessment. Risk calculations based on data from field studies have some uncertainties related to spatio-temporal unevenness of contaminant distribution in the environment, the characteristics of individual exposure, and the time frame of experimental studies. In this work, an assessment of the public health risks during the active phase of SNF and RW management was carried out. The radiation and chemical risks related to environmental contamination with heavy metals were determined according to a conservative scenario for a hypothetical person exposed to radioactive and chemical pollutants during the average life span (70 years). To avoid hazard underestimation, we took the upper limits of the median confidence interval to calculate tentative risks levels at $\mathrm{P}=0.95$ taking into account extended uncertainty of radiation parameters and heavy metal measurements.

We calculated tentative radiation risk levels taking into account exposure to artificial radionuclides in soils and drinking water. According to the requirements R52.18.787-2013 (Table 6) the external exposure risk was found to be an order of magnitude higher than the internal exposure risk for population living in the examined area. The level of the total radiation risk, taking into account the uncertainty, is $5 \cdot 10^{-7}$, which corresponds to the level of «negligible» risk (lower than $1 \cdot 10^{-6}$ ). The risk estimated by the total AAED from all artificial sources also can be considered as «negligible». 
Table 6

The individual radiation risk for people living near the Gremikha district

\begin{tabular}{|c|c|c|c|c|}
\hline \multirow{3}{*}{ Parameter } & \multirow{3}{*}{$\begin{array}{r}\text { Specific } \\
\text { activity, } \\
\mathrm{Bq} / \mathrm{kg}(\mathrm{L})\end{array}$} & \multicolumn{3}{|c|}{ Individual radiation risk } \\
\hline & & \multicolumn{2}{|c|}{ Exposure } & \multirow{2}{*}{ Total } \\
\hline & & internal & external & \\
\hline \multicolumn{2}{|l|}{ Soil } & $3 \cdot 10^{-9}$ & $5 \cdot 10^{-7}$ & $5 \cdot 10^{-7}$ \\
\hline${ }^{137} \mathrm{Cs}$ & 25 & $8 \cdot 10^{-10}$ & $5 \cdot 10^{-7}$ & $5 \cdot 10^{-7}$ \\
\hline${ }^{90} \mathrm{Sr}$ & 9 & $2 \cdot 10^{-9}$ & $1 \cdot 10^{-9}$ & $3 \cdot 10^{-9}$ \\
\hline \multicolumn{2}{|l|}{ Water } & $1 \cdot 10^{-8}$ & - & $1 \cdot 10^{-8}$ \\
\hline${ }^{137} \mathrm{Cs}$ & 0,003 & $1 \cdot 10^{-9}$ & - & $1 \cdot 10^{-9}$ \\
\hline${ }^{90} \mathrm{Sr}$ & 0,001 & $9 \cdot 10^{-9}$ & - & $9 \cdot 10^{-9}$ \\
\hline \multicolumn{2}{|l|}{ Total risk } & $1 \cdot 10^{-8}$ & $5 \cdot 10^{-7}$ & $5 \cdot 10^{-7}$ \\
\hline
\end{tabular}

Note : *means it is the upper limit of median confidence interval at $P=0.95$ allowing for extended measurements uncertainty.

Table 7

Individual carcinogenic risks caused by chemical pollution of the environment

\begin{tabular}{|c|c|c|c|c|c|}
\hline \multirow{2}{*}{ Parameter } & \multirow{2}{*}{$\begin{array}{c}\text { Concen- } \\
\text { tration, } \\
\mathrm{mg} / \mathrm{kg}^{*}\end{array}$} & \multicolumn{3}{|c|}{ Individual carcinogenic risks } \\
\cline { 3 - 5 } & ingestion & inhalation & dermal & \\
\hline \multicolumn{2}{|c|}{ Soil } & $9 \cdot 10^{-8}$ & $2 \cdot 10^{-8}$ & $5 \cdot 10^{-8}$ & $2 \cdot 10^{-7}$ \\
\hline $\mathrm{Pb}$ & 190 & $4 \cdot 10^{-8}$ & $6 \cdot 10^{-9}$ & $2 \cdot 10^{-8}$ & $7 \cdot 10^{-8}$ \\
\hline $\mathrm{As}$ & 0.9 & $3 \cdot 10^{-8}$ & $8 \cdot 10^{-9}$ & $6 \cdot 10^{-9}$ & $4 \cdot 10^{-8}$ \\
\hline $\mathrm{Cd}$ & 0.6 & $5 \cdot 10^{-9}$ & $3 \cdot 10^{-9}$ & $2 \cdot 10^{-8}$ & $3 \cdot 10^{-8}$ \\
\hline $\mathrm{Cr}$ & 113 & $1 \cdot 10^{-6}$ & $4 \cdot 10^{-7}$ & $5 \cdot 10^{-6}$ & $6 \cdot 10^{-6}$ \\
\hline
\end{tabular}

N o t e : * means the upper limit of median confidence interval at $P=0.95$, allowing for extended measurements uncertainty.

We also assessed the tentative risks of carcinogenic effects caused by exposure to heavy metals found in soils in the residential area in concentrations exceeding regional background levels (Table 7). Since we did not detect any carcinogenic potential for $\mathrm{Zn}, \mathrm{Cu}$, and $\mathrm{V}$, the assessment was accomplished for $\mathrm{Pb}, \mathrm{As}, \mathrm{Cd}$ and $\mathrm{Cr}$.
The calculated levels of carcinogenic risks taking into account all intake ways (ingestion, inhalation, and dermal) did not exceed the minimum range of carcinogenic risk (lower than $10^{-6}$ ) and corresponded to the «negligible» acceptance criterion.

Comparing the risks caused by the studied contaminants, we took into account general linear dependence concept for assessing the carcinogenic risks to low exposure doses and low concentrations of carcinogenic chemicals. Our comparison indicates no prevailing contributions made by radiation and chemical pollutants into carcinogenic risks [10].

Conclusions. Health physics situation in the residential area located near the Navy's former shore technical base (Gremikha peninsula) is characterized by background concentrations of artificial radionuclides ${ }^{137} \mathrm{Cs}$ and ${ }^{90} \mathrm{Sr}$ in environmental media. However, heavy metal soil contamination in the residential area is characterized by chemicals concentrations exceeding regional background levels. Comprehensive assessment of carcinogenic health risks to the public caused by exposure to radiation and chemical factors showed comparable results. Risks levels did not exceed $10^{-6}$ and were negligible.

The obtained results show that current industrial activities at the nuclear legacy site NWC «SevRAO» Gremikha during site decommissioning do not create additional risks of exposure to radionuclides and heavy metals for the population and the environment.

Funding. The research was not granted any sponsor support.

Conflict of interests. The authors declare there is no any conflict of interests.

\section{References}

1. Linge I.I., Vorob'eva L.M., Shashina T.A. The structure of environmental risk factors to the population's health in the Kolsky north. Gigiena i sanitariya, 2009, no. 5, pp. 51-54 (in Russian).

2. Smith G.M., Smith K.L., Kowe R., Pérez-Sánchez D., Molinero J. Recent developments in assessment of long-term radionuclide behavior in the geosphere-biosphere subsystem. Journal of Environmental Radioactivity, 2012, vol. 131, pp. 89-109. DOI: 10.1016/j.jenvrad.2013.10.018

3. Sneve M.K., Popic J.M., Siegien-Iwaniuk K. Regulatory Supervision of Legacy Sites: The Process from Recognition to Resolution. Report of an international workshop. Lillehammer, 2017, $115 \mathrm{p}$. 
4. Kotenko K.V., Shandala N.K. Problems of nuclear heritage regulation (review). Saratovskii nauchno-meditsinskii zhurnal, 2013, vol. 9, no. 4, pp. 811-815 (in Russian).

5. Panov A.V., Sanzharova N.I., Perevolotskii A.N., Perevolotskaya T.V., Naumov V.S. Analysis of the current national regulatory system EOF radiation safety of public and radiation protection of environment nearby facilities and sites outside the facilities contaminated with artificial and natural radionuclides due to their past operation. Radiatsiya i risk, 2017, vol. 26, no. 2, pp. 107-121 (in Russian).

6. Blinova L.D., Dushin V.N. Methodological approaches to environmental risk assessment under nu-clear facilities normal operation, comparative risk assessment. Trudy radievogo instituta im. V.G. Khlopina, 2003, vol. 10, pp. 92-105 (in Russian).

7. Arutyunyan R.V., Grachev V.A. Risk-oriented approach to analysis of safety living in the vicinity of atomic energy facilities. Review. Radiatsiya i risk, 2018, vol. 27, no. 2, pp. 117-140 (in Russian).

8. Radioekologicheskaya obstanovka $\mathrm{v}$ regionakh raspolozheniya predpriyatii Rosatoma [Radio-ecological situation in regions where Rosatom enterprises are located]. In: I.I. Linge, I.I. Krysheva eds. Moscow, «SAMpoligrafist» Publ., 2015, 296 p. (in Russian).

9. Rakhmanin Yu.A., Ivanov S.I., Novikov S.M., Revazova Yu.A., Rusakov N.V. Topical problems of the comprehensive hygienic characterization of urban environmental factors and their influence on the population's health. Gigiena i sanitariya, 2007, no. 5, pp. 5-8 (in Russian).

10. Biblin A.M., Zykova I.A., Koroleva T.M., Nikolaevich M.S. Methodological approaches to assessments of health risks in hygienic research. Radiatsionnaya gigiena, 2013, vol. 6, no. 2, pp. 32-38 (in Russian).

11. Panchenko S.V., Arakelyan A.A., Vedernikova M.V., Potsyapun N.P., Kargin O.A., Sikora O.N., Stepanova U.G. Comparative assessment of radiation and chemical risks in the city of Angarsk. Radiatsiya i risk, 2017, vol. 26, no. 2, pp. 83-96 (in Russian).

12. Novikov S.M., Shashina T.A., Dodina N.S., Kislitsin V.A., Skovronskaya S.A., Matsyuk A.V., Panchenko S.V., Arakelyan A.A. The experience of empirical research on comparative assessment of radiation and chemical health risks due to exposure to environmental factors. Gigiena i sanitariya, 2019, vol. 98, no. 12, pp. 1425-1431 (in Russian).

13. Belyaev E.N., Fokin M.V., Novikov S.M., Prusakov V.M., Shashina T.A., Shayakhmetov S.F. Actual problems of improving the assessment of health risk for assurance of the sanitary and epidemiological well-being. Gigiena i sanitariya, 2013, vol. 92, no. 5, pp. 53-55 (in Russian).

14. Romanovich I.K. Termination of the nuclear and radiation legacy of Russia: scientific basis for the radiation-hygienic regulation. Radiatsionnaya gigiena, 2019, vol. 12, no. 3, pp. 114-119 (in Russian).

15. Muratov O.E. Yadernoe nasledie na Severo-Zapade Rossii. Problemy i resheniya [Nuclear legacy in north-western Russia. Problems and solutions]. Atomnaya strategiya, 2019, no. 147, pp. 7-11 (in Russian).

16. Shandala N.K., Kiselev S.M., Titov A.V. Scientific and practical experience of supervisory activities in the field of the public and environmental protection at the Russian nuclear legacy sites. Radiatsionnaya gigiena, 2019, vol. 12, no. 2, pp. 83-96 (in Russian).

17. Kiselev S.M., Akhromeev S.V., Geras'kin S.A., Udalova A.A., Starinskii V.G., Shlygin V.V., Gimadova T.I., Shandala N.K. Assessment of natural environment at nuclear legacy sites are located in far eastern region of Russia. Voprosy radiatsionnoi bezopasnosti, 2017, vol. 88, no. 4, pp. 27-42 (in Russian).

18. Publikatsiya 103 Mezhdunarodnoi Komissii po radiatsionnoi zashchite (MKRZ) [Publication 103 by the International Commission on Radiological Protection]. In: M.F. Kiselev, N.K. Shandala eds. Moscow, OOO PKF «Alana» Publ., 2009, 344 p. (in Russian).

19. Kiselev S.M., Shlygin V.V., Akhromeev S.V., Lashchenova T.N., Starinskaya R., Gimadova T.I., Zozul Ju., Shandala N.K. Regulatory supervision during decommissioning \& dismantling of nuclear submarines in the Russian Northwest. Seventh International Conference on Radiation in Various Fields of Research. Book of Abstracts, 2019, pp. 342. 
20. Ofitsial'nyi sait Pravitel'stva Murmanskoi oblasti [Murmansk regional government - the official web-site]. Pravitel'stvo Murmanskoi oblasti. Available at: https://gov-murman.ru/ (10.07.2020) (in Russian).

Kiselev S.M., Shandala N.K., Lashchenova T.N., Zozul Yu.N., Shlygin V.V., Gimadova T.I., Malakhova A.N. Health risk analysis as per radiation and chemical factors in a zone influenced by a nuclear legacy object. Health Risk Analysis, 2021, no. 1, pp. 38-47. DOI: 10.21668/health.risk/2021.1.04.eng

Received: 20.09.2020

Accepted: 07.02.2021

Published: 30.03 .2021 
UDC 612.12: 616.092

DOI: $10.21668 /$ health.risk/2021.1.05.eng

Research article

\title{
OMIC MARKERS IDENTIFICATION FOR PREDICTING RISKS OF NEGATIVE EFFECTS IN CHILDREN WITH ELEVATED COPPER AND NICKEL CONTENTS IN BLOOD
}

\author{
N.V. Zaitseva ${ }^{1}$, M.A. Zemlyanova ${ }^{1,2}$, Yu.V. Koldibekova ${ }^{1}$, N.I. Bulatova ${ }^{1}$ \\ ${ }^{1}$ Federal Scientific Center for Medical and Preventive Health Risk Management Technologies, 82 Monastyrskaya Str., \\ Perm, 614045, Russian Federation \\ ${ }^{2}$ Perm State University, 15 Bukireva Str., Perm, 614990, Russian Federation
}

Proteomic profiling is a promising procedure for examining and substantiating molecular mechanisms of body reactions occurrence and development as a response to adverse impacts; it allows detecting and examining these reactions at early stages in their development prior to cellular damage and damage to organs. Studies aimed at increasing efficiency of adverse effects prediction are especially vital for solving tasks related to early detection and prevention of consequences associated with exposure to chemical environmental factors, first of all, ambient air.

Our research goal was to identify omic-markers for predicting risks of negative effects in children with elevated copper and nickel contents in blood.

We performed proteomic blood plasma examination in children and modeled cause-and-effect relations. Children with copper and nickel contents in their blood being 3.5 times higher than physiological standard had approximately 20 protein stains that were authentically different from those detected in children from the reference group. We detected correlations between an increase in relative volume of three protein stains including apolipoprotein A-I, anchor protein of A-kinase 9, vitronectin, and a decrease in relative volume of one protein strain including transthyretin and elevated copper and nickel contents in blood $\left(R^{2}=0.30-0.44 ; p=0.0001-0.008\right)$. All the above-mentioned proteins have predictive significance when it comes down to negative effects related to neuroregulation disorders and endothelial dysfunction. It was proven that there was a risk of predicted negative effects such as greater frequency of nervous and cardiovascular system diseases in case copper and nickel contents in blood were elevated $\left(R^{2}=0.35-0.96 ; p=0.0001-0.013\right)$. The established list of potential target molecules (apolipoprotein A-I, vitronectin, anchor protein of A-kinase 9, and transthyretin) and genes that coded their expression (APOA1, VTN,AKAP9,TTR) was substantiated as omic-markers indicating a possibility that negative effects might occur in the cardiovascular and nervous system.

Key words: copper and nickel in blood, health risk, proteomic profile of blood plasma, nervous system, cardiovascular system, apolipoprotein A-I, anchor protein of A-kinase 9, vitronectin, transthyretin.

There are certain priorities fixed within these priorities, research that concentrates on national and international strategies for scientific research development in fundamental medicine for the period up to $2025^{1}$. Given specific changes in regulatory mechanisms of homeostasis at the molecular level becomes especially important since it allows efficient

(C) Zaitseva N.V., Zemlyanova M.A., Koldibekova Yu.V., Bulatova N.I., 2021

Nina V. Zaitseva - Academician of the Russian Academy of Sciences, Doctor of Medical Sciences, Professor, Scientific Director (e-mail: znv@fcrisk.ru; tel.: +7 (342) 237-25-34; ORCID: https://orcid.org/0000-0003-2356-1145).

Marina A. Zemlyanova - Doctor of Medical Sciences, Chief Researcher acting as the Head of the Department for Biochemical and Cytogenetic Diagnostic Techniques (e-mail: zem@fcrisk.ru; tel.: +7 (342) 236-39-30; ORCID: http://orcid.org/00000002-8013-9613).

Yuliya V. Koldibekova - Candidate of Biological Sciences, Senior researcher acting as the Head of the Laboratory for Metabolism and Pharmacokinetics at the Department for Biochemical and Cytogenetic Diagnostic Techniques (e-mail: koldibekova@fcrisk.ru; tel.: +7 (342) 237-18-15; ORCID: http://orcid.org/0000-0002-3924-4526).

Natal'ya I. Bulatova - Researcher at the Laboratory for Biochemical and Nanosensory Diagnostics, Federal Scientific Center for Medical and Preventive Health Risk Management Technologies (e-mail: 1179815@mail.ru; tel.: +7 (3422) 36-80-18; ORCID: https://orcid.org/0000-0003-3392-9097).

${ }^{1}$ On Approval of the Strategy for medical science development in the Russian Federation for the period up to 2025: The Order by the RF Government dated December 28, 2012 No. 2580-r. Garant.Ru. The information and legal portal. Available at: https://www.garant.ru/products/ipo/prime/doc/70192396/ (20.09.2019) (in Russian). 
predicting and assessing potential negative effects at the earliest stage in their development. This research is accomplished with «Prevention medium» scientific platform.

Extremely high ambient air contamination with chemicals, including highly toxic nickel and copper compounds, results in risks of negative effects produced on the respiratory organs, blood system, immune system, and nervous system ${ }^{2}$.

Given that, it becomes especially vital to identify changes in homeostasis at the molecular level. Studies that focus on peptide pools fully correspond to these requirements since such pools play an exceptional role in bioregulation occurring in live organisms. Proteomic profiling is an efficient tool that allows analyzing peptides, as well as their ultimate and intermediate metabolites in a cell [1-4]. This procedure allows examining and substantiating etiological pathogenetic mechanisms of responses occurring and developing in a body due to exposure to adverse factors at their earliest stages, prior to any symptoms of damage to cells and organs, that is, at the level where transformed proteomic blood plasma profile is examined. To predict expression of these peptides, it is important to determine genes that code them; existing databases (for example, Sviss Prot) provide an opportunity to do it. The outlined issue confirms it is vital to perform studies aimed at identifying molecular omic-markers for early detection and prevention of consequences caused by aerogenic exposure to metals $[5,6]$.

Our research goal was to reveal omicmarkers for predicting risks of negative effects in children with elevated copper and nickel contents in blood.

Data and methods. Our research objects were blood plasma samples taken from 20 children aged 4-6 with elevated copper and nickel contents in blood (the test group) and 10 children with these metals detected in their blood in concentrations that corresponded to minimal or reference values (the reference group).

The present research work was accomplished in full conformity with ethical requirements fixed in the Helsinki Declaration (last edited in 2013) and was approved on by the Ethical Committee of the Rospotrebnadzor's Federal Scientific Center for Medical and Preventive Health Risk Management Technologies. Both groups were comparable as per age and gender and didn't have any differences regarding social and economic factors that might cause health risks. Children's legal representatives gave their voluntary written informed consent on underage children's participation in the research and publication of relevant data on them.

Chemical-analytical blood examination aimed at determining nickel and copper contents in blood was performed in conformity with the valid Methodical Guidelines MUK 4.1.3230-14 «Measuring mass concentrations of chemicals in biological media (blood and urine) with mass spectrometry with inductively coupled plasma» ${ }^{3}$. To do that, we used relevant analytical equipment, namely Agilent 7500cx (the USA) mass spectrometer with inductively coupled argon plasma.

Proteomic blood plasma profile of children from the test and reference groups was performed according to two-dimensional electrophoresis procedure in polyacrylamide gel as per methods recommended for the equipment in use [7-9]. Obtained blood plasma electrophoregrams were visualized via dying with silver and documented with a system for geldocumenting (Bio-Rad, the USA). Obtained proteomic maps were analyzed with PDQuest software (Bio-Rad, the USA). We spotted out significant protein stains in obtained proteinograms and performed subsequent analysis via

${ }^{2} \mathrm{R}$ 2.1.10.1920-04. Assessment of population health risks under exposure to chemicals that pollute the environment: Guide. Moscow, The Federal center for state sanitary and epidemiologic surveillance of the RF Public Healthcare Ministry Publ., 2004, 143 p. (in Russian).

${ }^{3}$ MUK 4.1.3230-14. Measuring mass concentrations of chemicals in biological media (blood and urine) with mass spectrometry with inductively coupled plasma. Approved by the RF Chief Sanitary Inspector A.Yu. Popova on December 19, 2014. KODEKS: an electronic fund for legal and reference documentation. Available at: http://docs.cntd.ru/document/495856222 (22.09.2019) (in Russian). 
liquid chromatography combined with massspectrometry with UltiMate chromatograph 3000 (Germany) ABSciex 4000 QTRAP tandem mass-spectrometer with Nanospray 3 ionization source (Canada). Data obtained via tandem experiments were processed with ProteinPilot software, version 4.5 (AB SCIEX) with identification as per UniProt_sprot fasta database (version issued on November 24,2017 ), and with a sampling made as per HomoSapience taxon. Most data on obtained proteins were taken from UniProt databases. We determined genes that identified proteins corresponded to with HGNC database of human gene name.

Sampling properties were given as simple mean $(M)$ and error of representativeness $(m)$. We used Mann-Whitney test to determine whether discrepancies between the test and reference groups were significant. Data were statistically processed with Statistica 10 software.

To perform comparative analysis of predicted negative effects among the examined children aged $4-6$, we took data on morbidity among children aged 10-12 (as per ICD-10) obtained via profound medical examinations.

Marker protein stains were substantiated basing on detected authentic cause-and-effect relations described with multi-factor models showing «statistically significant stain - nickel

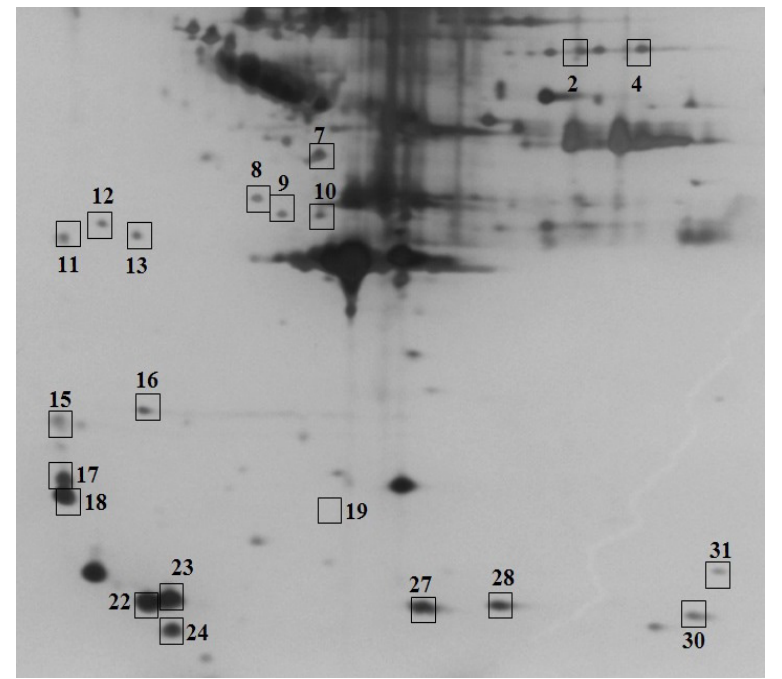

Figure 1. A part of 2DE-gel of children's blood plasma: a child from the test group, number of protein stains are given concentration in blood» dependence with linear regression. To test whether the obtained models were valid and relevant, we performed dispersion analysis with Fischer's test $F$, determination coefficient $\left(R^{2}\right)$, and Student's t-test with statistical significance taken as $p \leq 0.05$.

Results and discussion. We analyzed results obtained via chemical-analytical examination aimed at determining nickel and copper contents in blood; the analysis revealed that children in the test group had 1.2 times higher copper contents in blood $\left(1.04 \pm 0.09 \mathrm{mg} / \mathrm{dm}^{3}\right)$ against the reference group $\quad\left(0.87 \pm 0.09 \mathrm{mg} / \mathrm{dm}^{3}\right) \quad(p=0.011)$; nickel contents in their blood was also up to 3.5 times higher $\left(0.007 \pm 0.002 \mathrm{mg} / \mathrm{dm}^{3}\right)$ against the same parameter $\left(0.002 \pm 0.0001 \mathrm{mg} / \mathrm{dm}^{3}\right)$ in the reference group $(p=0.001)$. A share of samples with nickel and copper contents being higher than reference values ${ }^{4}\left(\mathrm{RfL}_{\text {copper }}=\right.$ $=0.09 \mathrm{mg} / \mathrm{dm}^{3}, \mathrm{RfL}_{\text {nickel }}=0.001 \mathrm{mg} / \mathrm{dm}^{3}$ ) varied from $77.0 \%$ to $82.0 \%$ of all the examined children in the test group whereas it was only from $10.0 \%$ to $20.0 \%$ in the reference group.

Two-dimensional electrophoresis allowed obtaining proteomic blood plasma maps for children from the examined samples; relative protein stains volumes were determined in them via densitometry (Figures 1 and 2).

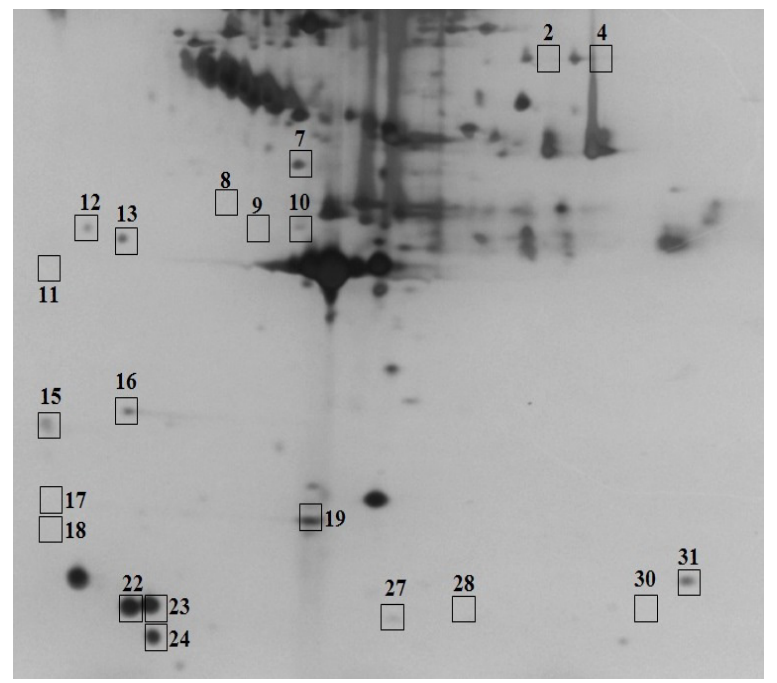

Figure 2. A part of 2DE-gel of children's blood plasma: a child from the reference group, number of protein stains are given

\footnotetext{
${ }^{4}$ N.U. Tits. Clinical guide on laboratory tests. Moscow, UNIMED-press Publ., 2003, 570 p. (in Russian).
} 
We performed comparative analysis of results obtained via densitometry measuring of proteomic blood plasma maps obtained for the examined children; the analysis allowed revealing authentic discrepancies in relative volumes of approximately 20 protein stains between children from the test and the reference group (Table 1).

Children from the test group had proteins stains No. 12 and No. 18 that had 8.0-12.2 times greater volume and protein stain No. 19 that had 5.4 times lower volume than the same stains in children from the reference group $(p=0.0001)$. The above said proteins and genes that code their expression are given in Table 2.

Figure 3 shows an example spectrum for a peptide that has a correlation with simultane- ous elevated copper and nickel contents in blood.

Having built multi-factor models, we established direct cause-and-effect relations between elevated copper and nickel contents in blood and an increase in relative volume of protein stain No. 12 that included a sequence of apolypoprotein A-I and A-kinase 9 anchor protein $\left(R^{2}=0.30 ; b_{0}=-656.8 ; b_{1}=1,801.1\right.$; $\left.b_{2}=63,518.1 ; p=0.008\right)$ and protein stain No. 18 (vitronectin) $\left(R^{2}=0.44 ; b_{0}=-1,372.0\right.$; $\left.b_{1}=2,743.3 ; b_{2}=112,937.0 ; p=0.0001\right)$. We also detected inverse dependence between a decrease in relative volume of protein stain No. 19 that included transthyretin and elevated copper and nickel contents in blood $\left(R^{2}=0.35 ; \quad b_{0}=4,870.1 ; b_{1}=-3,266.9 ; b_{2}=\right.$ $=-79,946.5 ; p=0.003)$.

Table 1

A spectrum showing peptides and proteins determined in proteomic blood plasma profile of children with elevated copper and nickel contents in blood

\begin{tabular}{|c|c|c|c|}
\hline Stain number & Peptide spectrum & $\begin{array}{l}\text { Peptide identifica- } \\
\text { tion probability, } \%\end{array}$ & Protein name \\
\hline \multirow{2}{*}{ Stain No. 2} & RVDGSVDFYRDWATYK & \begin{tabular}{|c|}
1.0 \\
\end{tabular} & \multirow{2}{*}{ Ficolin-2 } \\
\hline & VDLVDFEDNYQFAK & 56.6 & \\
\hline \multirow{3}{*}{ Stain No. 4} & VDGSVDFYR & 88.0 & \multirow{2}{*}{ Ficolin -2} \\
\hline & VDLVDFEDNYQFAK & 99.0 & \\
\hline & VNVDEVGGEALGR & 99.0 & Hemoglobin subunit beta \\
\hline Stain No. 8 & INGKPLPGATPAK & 40.6 & tRNAselenocysteine 1-associated protein 1 \\
\hline \multirow{7}{*}{ Stain No. 9} & GLCVATPVQLR & 99.0 & \multirow{3}{*}{ Complement component C4-B } \\
\hline & GSFEFPGDVSK & 64.9 & \\
\hline & LGQYASPTAKRCCQDGVTR & 1.0 & \\
\hline & QRIEALSLMHPSISFSLR & 59.0 & \multirow{3}{*}{ DNA mismatch repair protein Mlh3 } \\
\hline & DSEATR & 1.0 & \\
\hline & FYGFR & 1.0 & \\
\hline & GVGKVPR & 34.1 & P2Y purinergic receptor 12 \\
\hline Stain No. 10 & NIVQNVR & 26.1 & Sideroflexin-3 \\
\hline \multirow{4}{*}{ Stain No. 11} & VSFLSALEEYTK & 99.0 & \multirow{3}{*}{ Apolypoprotein A-I } \\
\hline & QGLLPVLESFK & 33.6 & \\
\hline & VKDLATVYVDVLK & 3.8 & \\
\hline & VDTLEIQGDVTLSYVQIR & 32.2 & Galectin-4 \\
\hline \multirow{3}{*}{ Stain No. 12} & DYVSQFEGSALGK & 99.0 & \multirow{2}{*}{ Apolypoprotein A-I } \\
\hline & QGLLPVLESFK & 59.9 & \\
\hline & LLKILLEVVK & 52.3 & A-kinase 9 anchor protein \\
\hline \multirow[t]{8}{*}{ Stain No. 13} & CYTAVVPLVYGGETK & 99.0 & \multirow{4}{*}{ Immunoglobulin J-chin } \\
\hline & FVYHLSDLCK & 99.0 & \\
\hline & AVHVKAQEDER & 1.0 & \\
\hline & NHLLFWGVLAFIK & 1.0 & \\
\hline & RPSTPR & 73.2 & \multirow[t]{4}{*}{ Protein faggot } \\
\hline & EKQFLNAESAYMDPMK & 0.2 & \\
\hline & DRGGRDYPPLR & 1.0 & \\
\hline & DSTSTAPDSQR & 0.1 & \\
\hline
\end{tabular}




\begin{tabular}{|c|c|c|c|}
\hline & LEPLGPGSSGRPGK & 1.0 & \\
\hline & VLRDGGCSLPIIPNITK & 0.2 & \\
\hline & HRAAEAAINILK & 72.9 & $\begin{array}{l}\text { Interferon-induced activator of two-chain } \\
\text { RNA-dependent protein kinase A }\end{array}$ \\
\hline & GLEEELQFSLGSK & 99.0 & Comnlement comnonent $\mathrm{C}_{4}-\mathrm{B}$ \\
\hline Stain No 15 & DVPRGQVVK & 1.0 & 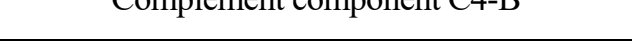 \\
\hline Stamin No. 15 & HQDFNSAVQLVENFCR & 99.0 & Prothrombin \\
\hline & LAVTTHGLPCLAWASAQAK & 18.3 & Frotnromom \\
\hline & GLEEELQFSLGSK & 99.0 & Complement component C4-B \\
\hline Stain No. 16 & MPYSVGFR & 23.6 & Ankyrin-1 \\
\hline & CYGMTDDKVDK & 1.0 & Anкупा-1 \\
\hline Stain No. 17 & SIAQYWLGCPAPGHLR & 77.2 & Vitronectin \\
\hline Stain No. 18 & SIAQYWLGCPAPGHLR & 95.9 & Vitronectin \\
\hline & GSPAINVAVHVFR & 99.0 & \\
\hline Stain No 19 & TSESGELHGLTTEEEFVEGIYK & 99.0 & Transthyretin \\
\hline Staln No. 19 & ALGISPFHEHAEVVFTANDSGPR & 94.7 & Iranstuyreum \\
\hline & AADDTWEPFASCK & 99.0 & \\
\hline & DALSSVQESQVAQQAR & 99.0 & Anolynonrotein C-III \\
\hline & GWVTDGFSSLK & 99.0 & \\
\hline Stain No. 22 & DLTEAVPR & 94.1 & Myotubularin \\
\hline Stalli 1 vo. 22 & RDGPGLER & 42.7 & $\begin{array}{c}\text { NAD-dependent protein -diacetyl ASA-sirtuin- } \\
1\end{array}$ \\
\hline & LKSGSGPVR & 32.4 & Necleoplasmin-3 \\
\hline & SIAQYWLGCPAPGHLR & 99.0 & Vitronectin \\
\hline Stain No. 23 & DALSSVQESQVAQQAR & 3.9 & Anolynonrotein C-III \\
\hline & GWVTDGFSSLK & 42.2 & Aporypoprotem C-III \\
\hline Stain No. 24 & ESLSSYWESAK & 99.0 & Apolypoprotein C-II \\
\hline & FFGHGAEDSLADQAANEWGR & 96.5 & Serum amyloid nrotein $4-1$ \\
\hline Stain No. 27 & FFGHGAEDSLAPQAANEWGR & 1.0 & Serum amyiora protem A-1 \\
\hline & RGPGGAWAAEVISNAR & 93.0 & Serum amyloid protein A-2 \\
\hline & SFFSFLGEAFDGAR & 99.0 & Serum amyloid protein A-2 \\
\hline & LVAASQAALGLK & 79.1 & \\
\hline Stain No. 28 & APLAKYIGENQDSISSK & 1.0 & 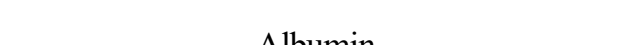 \\
\hline & YIGENQDSISSKLK & 1.0 & Aloumm \\
\hline & VFDEFKPLVEEPQNLIK & 99.0 & \\
\hline & SAVTALWGK & 99.0 & \\
\hline Stain No. 30 & VNVDEVGGEALGR & 99.0 & Hemoglobin subunit beta \\
\hline & VLGAFSDGLAHLDNLK & 55.6 & \\
\hline Stain No. 31 & LLVVYPWTQR & 99.0 & Hemoglobin subunit gamma-2 \\
\hline
\end{tabular}

Table 2

Proteins and genes coding them that have a correlation with elevated nickel and copper contents in blood

\begin{tabular}{|c|c|c|c|c|c|c|}
\hline \multirow{2}{*}{$\begin{array}{l}\text { Protein } \\
\text { stain } \\
\text { No. }\end{array}$} & \multirow{2}{*}{$\begin{array}{l}\text { A trend in } \\
\text { protein vol- } \\
\text { ume change }\end{array}$} & \multirow{2}{*}{ Protein } & \multicolumn{2}{|c|}{$\begin{array}{l}\text { Relative volume of protein stain } \\
(\mathrm{M} \pm \mathrm{m}) \text {, int }\end{array}$} & \multirow{2}{*}{$\begin{array}{l}\text { A gene } \\
\text { that codes } \\
\text { a protein }\end{array}$} & \multirow{2}{*}{$\begin{array}{l}\text { Code of a gene } \\
\text { that codes a pro- } \\
\text { tein in Sviss } \\
\text { Prot database }\end{array}$} \\
\hline & & & $\begin{array}{c}\text { Test group } \\
(n=20)\end{array}$ & $\begin{array}{c}\text { Reference group } \\
(n=10)\end{array}$ & & \\
\hline \multirow{2}{*}{12} & \multirow{2}{*}{ Increase } & Apolypoprotein A-I & \multirow{2}{*}{$2,099 \pm 135^{* *}$} & \multirow{2}{*}{$171 \pm 46$} & APOA1 & P02647 \\
\hline & & A-kinase 9 anchor protein & & & AKAP9 & Q99996 \\
\hline 18 & Increase & Vitronectin & $2,731 \pm 337^{* *}$ & $340 \pm 101$ & VTN & P04004 \\
\hline 19 & Decrease & Transthyretin & $498 \pm 143^{* *}$ & $2,687 \pm 746$ & TTR & P02766 \\
\hline
\end{tabular}

Note:

int $_{* *}^{*}$ means protein stain intensity;

${ }^{* *}$ means discrepancies between mean values are valid, $p \leq 0.05$. 


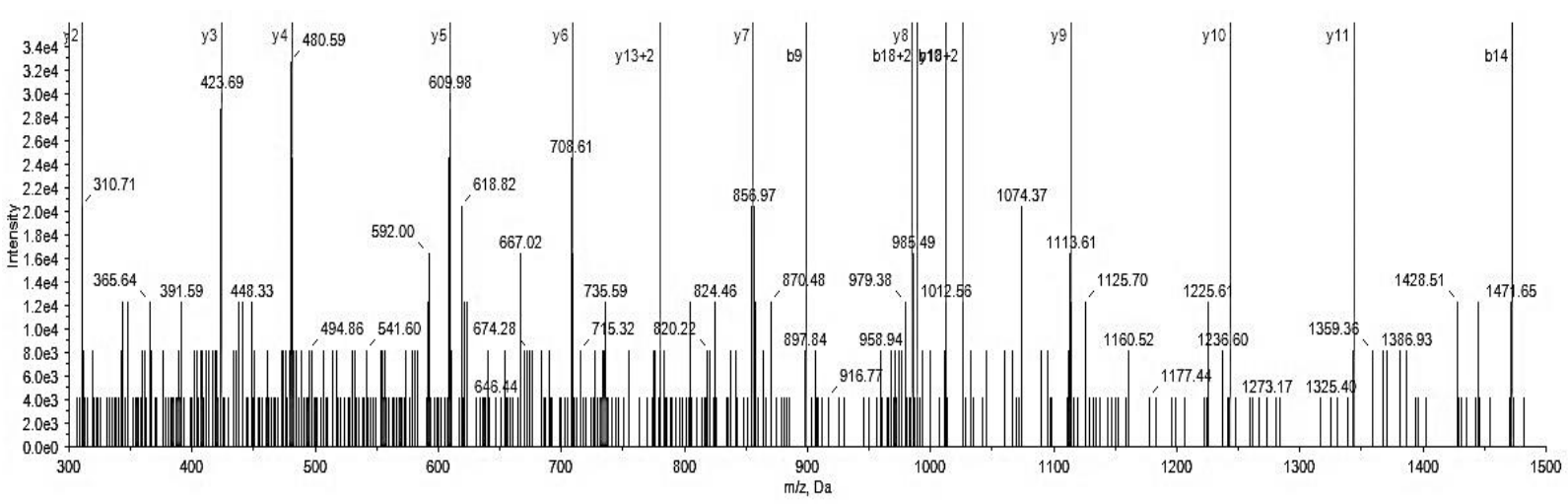

Figure 3. Spectrum for TSESGELHGLTTEEEFVEGIYK peptide (Transthyretin)

(SwissProt database) in a child's blood plasma, stain No. 19

We analyzed biological functions performed by the identified proteins in blood plasma as per data provided in both Russian and foreign scientific works; the results allow predicting certain adverse effects occurring in the cardiovascular and nervous system. Thus, indentified apolypoprotein A-I and vitronectin are predominantly connected with endothelial dysfunction that in future may result in arterial hypertension and cardiomyopathy [10]. Apolypoprotein A-I belongs to high density lipoproteins; it releases cells from excessive cholesterol thus preventing atherosclerosis plaques formation and making for greater elasticity of vessels endothelium [11-13]. Vitronectin is a cellular-adhesive glycoprotein produced and released by liver cells; in pathologic state it is bonded with cellular surfaces, for example, with activated thrombocytes and extracellular matrices in various tissues (fibrin) [14]. As a result, thrombocytes adhesion and their local aggregation enhance as it has been confirmed via experimental research $[15$, $16]$. In case there is a growth in relative volume of a protein stain that contains apolypoprotein A-I and vitronectin and nickel and copper contents in blood are elevated, we can predict damage to endothelial cells of blood vessels done by reactive oxygen species, anti-inflammation reaction being induced, and cytokines being released from heart tissues via such transcription factors as $\mathrm{NF}-\kappa \mathrm{B}$ (nuclear factor kappa-B) and AP-1 (activator protein 1) as it was described in several foreign and Russian research works $[17,18]$.

A-kinase 9 anchor protein characterizes changes in neural regulation since several its isoforms are able to get bonded to N-methyl$\mathrm{D}$-aspartate receptor in neuromuscular junction and neuron synapses; it means that there are changes in how postsynaptic specialization is organized [19]. As per data obtained via experimental research, excessive expression of this protein may result in mitochondria becoming longer and an in increase in membrane potential thus making neurons less sensitive to constant strain in transferring signals $[19,20]$. Transthyretin, in its turn, is a protein that plays an important role in the nervous system development, neuronal growth and synapses genesis as well as cytoarchitecture regulation that support cognitive functions performed by the central nervous system (memory, emotional state, and mental health) $[21,22]$. This assumption is confirmed by results obtained via experimental research performed by foreign experts [21, 23]. Changes in transthyretin expression may lead to various cognitive disorders and behavioral deviations [23].

We performed comparative analysis of established changes in proteomic blood plasma profile of children aged 4-6 and negative effects that turned into actual diseases in children aged 10-12; the results allowed revealing authentic 2.2-3.0 times greater frequency of cardiovascular diseases (cardiomyopathy, I42) 
and diseases of the nervous system (functional disorders of the central and vegetative nervous system, G90.9, G90.8) against the same parameters in the reference group $(p=0.001-0.032)$. And we also established authentic dependence between greater frequency of nervous diseases (functional disorders in the nervous system) and cardiomyopathy and elevated copper and nickel contents in blood for children aged $10-12 \quad\left(R^{2}=0.35-0.96 ; \quad-1.94 \leq b_{0} \geq-7.22\right.$; $\left.1.76 \leq b_{1} \geq 128.64 ; p=0.0001-0.013\right)$.

Therefore, the described and grounded omic-markers (apolypoprotein A-I, vitronectin, A-kinase 9 anchor protein, and transthyretin) and genes that code their expression (APOA1, VTN, AKAP9, and TTR) can be used to achieve more efficient prediction of negative effects related to disorders in neural regulation and endothelial dysfunction; it will allow early detection and prevention of negative outcomes for children's health under high aerogenic exposure to copper and nickel.

\section{Conclusions.}

1. Approximately 20 protein stains were authentically different in children from the test group with copper and nickel contents in blood being up to 3.5 times higher than in the reference group.

2. We established dependences between elevated copper and nickel contents in blood and an increase in relative volume of three protein stains that contained apolypoprotein
A-I, A-kinase 9 anchor protein, and vitronectin, and a decrease in relative volume of one protein stain that contained transthyretin $\left(R^{2}=0.30-0.44 ; p=0.0001-0.008\right)$.

3 . Changes in relative volume of protein stains that include apolypoprotein A-I, A-kinase 9 anchor protein, vitronectin, and transthyretin have predictive significance for determining probable negative effects related to neural regulation disorders and endothelial dysfunction.

4. Predicted negative effects were proven to actually occur as elevated frequency of nervous and cardiovascular diseases in case copper and nickel concentrations in blood were elevated $\left(R^{2}=0.35-0.96 ; p=0.0001-0.013\right)$.

5 . To predict probable negative effects occurring in the cardiovascular and nervous system prior to actual damage done to tissues and organs, we substantiated use of omicmarkers given ass proteins (apolypoprotein A-I, vitronectin, A-kinase 9 anchor protein, and transthyretin) and genes that code their expression (APOA1, VTN, AKAP9, TTR); these markers allow identifying transformed proteomic profiled associated with aerogenic exposure to copper and nickel.

Funding. The research was not granted any sponsor support.

Conflict of interests. The authors declare there is no any conflict of interests.

\section{References}

1. Barbarini N., Magni P. Accurate peak list extraction from proteomic mass spectra for identification and profiling studies. BMC. Bioinformatics, 2010, vol. 11, no. 518, pp. 1-14. DOI: 10.1186/1471-2105-11-518

2. Shenderov B.A. «Omik»-tekhnologii i ikh znachenie v sovremennoi profilakticheskoi i vosstanovitel'noi meditsine [«Omic»-technologies and their significance for contemporary preventive and recovery medicine]. Vestnik vosstanovitel'noi meditsiny, 2012, no. 3, pp. 70-78 (in Russian).

3. Polunina T.A., Varshavskaya Yu.S., Grigor'eva G.V., Krasnov Ya.M. Proteomic methods of protein separation and analysis. Zhurnal mikrobiologii, epidemiologii i immunobiologii, 2014, no. 3, pp. 107-114 (in Russian).

4. Ahn S.-M., Simpson R.J. Body fluid proteomics: Prospects for biomarker discovery. Proteomics Clin. Appl., 2007, vol. 1, no. 9, pp. 1004-1015. DOI: 10.1002/prca.200700217

5. Larina I.M., Ivanisenko V.A., Nikolaev E.N., Grigorev A.I. The proteome of a healthy human during physical activity under extreme conditions (Reviews). Acta Naturae, 2014, vol. 6, no. 3 (22), pp. 66-75. 
6. Aebersold R., Agar J., Amster I., Baker M.S., Bertozzi C.R., Boja E.S., C.E. Costello, B.F. Cravatt [et al.]. How many human proteoforms are there? Nature chemical biology, 2018, vol. 14, no. 3, pp. 206-214. DOI: 10.1038/nchembio.2576

7. PROTEAN i12 IEF System. Instruction Manual. Hercules, Bio-Rad Laboratories, Inc Publ., 2011,60 p.

8. PROTEAN II xi 2D cell. Instruction Manual. Hercules, Bio-Rad Laboratories, Inc Publ., $2011,52 \mathrm{p}$.

9. ReadyPrep 2-D starter Kit. Instruction manual. Hercules, Bio-Rad Laboratories, Inc Publ., 2011, 28 p.

10. Wu S., Deng F., Wei H., Huang J., Wang H., Shima M., Wang X., Qin Y. [et al.]. Chemical constituents of ambient particulate air pollution and biomarkers of in flammation, coagulation and homocysteine in healthy adults: a prospective panel study. Part. Fibre. Toxicol., 2012, vol. 9, no. 49, pp. 1-13. DOI: 10.1186/1743-8977-9-49

11. Knyazev R.A., Trifonova N.V., Ryabchenko A.V., Kotova M.V., Kolpakov A.R., Polyakov L.M. Impact of recombinant apolipoprotein A-I on myocardial function in experiment. Patologiya krovoobrashcheniya i kardiokhirurgiya, 2018, vol. 22, no. 4, pp. 88-94 (in Russian).

12. Maranhão R.C., Freitas F.R. HDL Metabolism and Atheroprotection: Predictive Value of Lipid Transfers. Advances in Clinical Chemistry, 2014, no. 65, pp. 1-41. DOI: 10.1016/B978-0-12800141-7.00001-2

13. Chumakova G.A., Gritsenko O.V., Veselovskaya N.G., Vakhromeeva E.V., Kozarenko A.A. Clinical role of apolipoproteins A and B. Kardiovaskulyarnaya terapiya i profilaktika, 2011, vol. 10, no. 6, pp. 105-111 (in Russian).

14. Masaharu H., Takeshi Y., Katsuko N., Ai S.-N., Tomoko F., Yuichi M., Takaya G., Katsushi T. Vitronectin improves cell survival after radiation injury in human umbilical vein endothelial cells. FEBS Open Bio, 2012, no. 2, pp. 334-338. DOI: 10.1016/j.fob.2012.10.002

15. Ruggeri Z.M., Jackson S.P. Platelet Thrombus Formation in Flowing Blood. Platelet biology, 2013, no. 2, pp. 399-423. DOI: 10.1016/B978-0-12-387837-3.00020-1

16. Konstantinides S., Schafer K., Thinnes T., Loskutoff D.J. Plasminogen activator inhibitor-1 and its cofactor vitronectin stabilize arterial thrombi after vascular injury in mice. Circulation, 2001, no. 103 , pp. 576-583. DOI: 10.1161/01.cir.103.4.576

17. Sarnat S.E., Winquist A., Schauer J.J., Turner J.R., Sarnat J.A. Fine particulate matter components and emergency department visits for cardiovascular and respiratory diseases in the St. Louis, Missouri-Illinois, Metropolitan Area. Environ. Health Perspect, 2015, vol. 5, no. 123, pp. 437-444. DOI: 10.1289/ehp.1307776

18. Kolpakova A.F., Sharipov R.N., Kolpakov F.A. Air pollution by particulate matter as the risk factor for the cardiovascular diseases. Gigiena i sanitariya, 2017, vol. 96, no. 2, pp. 133-137 (in Russian).

19. Liu Yu., Merrill R.A., Strack S. A-Kinase Anchoring Protein 1: Emerging Roles in Regulating Mitochondrial Form and Function in Health and Disease (Review). Cells, 2020, vol. 9, no. 298, pp. 2-12. DOI: $10.3390 /$ cells 9020298

20. Flippo K.H., Gnanasekaran A., Perkins G.A., Ajmal A., Merrill R.A., Dickey A.S., Taylor S.S., McKnight G.S. [et al.]. AKAP1 Protects from Cerebral Ischemic Stroke by Inhibiting Drp1Dependent Mitochondrial Fission. J. Neurosci, 2018, vol. 19, no. 38, pp. 8233-8242. DOI: 10.1523/JNEUROSCI.0649-18.2018

21. Remaud S., Gothié J.-D., Morvan-Dubois G., Demeneix B.A. Thyroid hormone signaling and adult neurogenesis in mammals. Front. Endocrinol, 2014, vol. 5, no. 62, pp. 1-7. DOI: $10.3389 /$ fendo.2014.00062

22. V'yunova T.V., Medvedeva E.V., Andreeva L.A., Dergunova L.V., Limborskaya S.A., Myasoedov N.F. A possible role of transthyretin in the biological mechanism of regulatory peptide neuroprotection. Molekulyarnaya genetika, mikrobiologiya i virusologiya, 2016, vol. 34, no. 3, pp. 104-109 (in Russian). 
23. Brouillette J., Quirion R. Transthyretin: a key gene involved in the maintenance of memory capacities during aging. Neurobiol. Aging., 2008, vol. 29, no. 11, pp. 1721-1732. DOI: 10.1016/j.neurobiolaging.2007.04.007

Zaitseva N.V., Zemlyanova M.A., Koldibekova Yu.V., Bulatova N.I. Omic markers identification for predicting risks of negative effects in children with elevated copper and nickel contents in blood. Health Risk Analysis, 2021, no. 1, pp. 48-56. DOI: 10.21668/health.risk/2021.1.05.eng

Received: 12.01 .2021

Accepted: 15.03 .2021

Published: 30.03 .2021 
UDC 613.26-613.28

DOI: 10.21668/health.risk/2021.1.06.eng

Research article

\title{
ASSESSMENT AND CLASSIFICATION OF FOOD PRODUCTS AS PER HEALTH RISKS CAUSED BY CHEMICAL AND MICROBIOLOGICAL CONTAMINATION
}

\author{
O.G. Bogdanova ${ }^{1}$, O.A. Molchanova ${ }^{1,2}$, I.Yu. Tarmaeva ${ }^{3}$, N.V. Efimova ${ }^{1}$ \\ ${ }^{1}$ East-Siberian Institute of Medical and Ecological Research, 12a the 3rd micro-district, Angarsk, 665827, \\ Russian Federation \\ ${ }^{2}$ Federal Service for Surveillance over Consumer Rights Protection and Human Wellbeing, Buryatiya Region \\ office, 45b Klyuchevskaya Str., Ulan-Ude, 670013, Russian Federation \\ ${ }^{3}$ Federal Research Centre of Nutrition, Biotechnology and Food Safety, 2/14 Ustinsky lane, Moscow, 109240, \\ Russian Federation
}

Our research goal was to reveal priority food products (FP) distributed on a regional consumer market as per health risks they caused for population.

The research was accomplished with statistic, analytical, and mathematical procedures as well as using comparative analysis procedure.

We analyzed laboratory data on sanitary-chemical and physical-chemical parameters collected over 2010-2019; our analysis revealed there were insignificant risks excluding FP contamination with nitrates. Special attention should be paid to microbiological contamination as overall parameters related to it remain steady over the compared 5-year periods. We also have detected unfavorable trends as average parameters have grown authentically over the last 5 years against 2010-2014 when it comes to fruit and vegetables, poultry, fish products, and alcoholic beverages with growth rates varying from 3.53 times to 1.44 times.

Having accomplished all the necessary calculations, we established that in Buryatia, just as in the Russian Federation in general, there were no food products that could cause extremely high health risks. But at the same time, the examined regional market had certain differences from the overall Russian one. High health risks were caused by poultry and it was not the case in the country in general. Bakery, confectionary, and fish products that caused high health risks in the country as a whole caused only significant risks in the region. Milk products also were assigned into a high risk category. We performed complex assessment and classified FP as per their quality and safety using health risk analysis methodology; it allowed us to determine priorities resulted from microbiological contamination of poultry and this fact is vital for population health in Buryatia.

Key words: food products, chemical and microbiological contamination, quality and safety, health risk, classification, complex assessment, nutrition for population, regional peculiarities, Buryatia.

Protecting life and health of people who proprietors or juridical persons who deal with consume food products (FPs) should be given food products distribution. It is fixed in the last a priority over any economic interests of sole alterations to the Federal $\mathrm{Law}^{1}$ «On food

(C) Bogdanova O.G., Molchanova O.A., Tarmaeva I.Yu., Efimova N.V., 2021

Olga G. Bogdanova - Candidate of Medical Science, $\mathrm{PhD}$, senior researcher at the Laboratory for Ecological and Hygienic Research (e-mail: olga.bogdanova2001@gmail.com; tel.: +7 (3955) 58-69-10; ORCID: https://orcid.org/0000-0002-2358-2280).

Olga A. Molchanova - post-graduate student; Deputy Head of the Department for Supervision over Food Hygiene and Hygiene of Children and Adolescents (e-mail: olga_molchanova_1992@mail.ru; tel.: +7 (3955) 58-69-10; ORCID: https://orcid.org/0000-0002-5088-4794).

Inna Yu. Tarmaeva - Doctor of Medical Science, Professor, Academic Secretary, Leading Researcher at the Laboratory for Age-related Nutrition Studies (e-mail: t38_69@mail.ru; tel.: +7 (495) 698-53-42; ORCID: https://orcid.org/0000-0001-7791-1222).

Natalia V. Efimova - Doctor of Medical Science, Professor, Leading Researcher at the Laboratory for Ecological and Hygienic Research (e-mail: medecolab@inbox.ru; tel.: +7 (3955) 58-69-10; ORCID: https://orcid.org/0000-0001-7218-2147).

${ }^{1}$ On making alterations into the Federal law «On food products quality and safety» and into Clause 37 in the Federal Law «On education in the Russian Federation» No. 47-FZ issued on March 01, 2020. KonsultantPlus. Available at: http:// www.consultant.ru/document/cons_doc_LAW_346666/(30.09.2020) (in Russian). 
products quality and safety» and is a major principle of healthy nutrition [1-3]. An issue related to providing people with qualitative FPs is becoming more and more vital every year since its integral component, namely providing safety of food raw materials and finished products, is a basic factor that predetermines people's health and gene pool preservation. Required safety can be provided, among other things, via meeting Technical Regulations that are valid in the Customs Union and the Eurasian Economic Union [4-9].

Providing stability when it comes down to this factor is nowadays a most complicated and urgent task the civilization has to face and international organizations have to focus on [10]. Let us turn to certain official data provided by the WHO. In 2019 unsafe food products that contained malignant bacteria and carcinogens were estimated to cause more than 200 various diseases, from diarrhea to cancer. As per WHO estimates, 600 million people or almost each tenth person all over the world get sick after having consumed contaminated food products; 420 thousand people die annually due to food contamination and it results in 33 million years of health life being lost (DALY) [11].

Innovative technologies that are now used to produce and store FPs have substantially changed people's lifestyle and nutrition structure, first of all, in developed countries [12]. Nowadays people tend to consume more and more finished culinary products bought at catering facilities and in culinary shops; these food products are usually made according to strict technological and culinary procedures fixed for their cooking and storage; these technological processes and procedures involve substantial losses of essential (necessary) nutrients, first of all, certain vitamins and minerals as well as technical contaminants accumulating in food products [13]. In 2011, basic HACCP (Hazard Analysis and Critical Control Points) and a necessity to adhere to them were fixed in the EAEU legislation on technical regulation. But at the same time even when FPs manufacturing is controlled with HACCP princi- ples being used all the manufactured products can acquire certain properties during their distribution on consumer market that can be hazardous for people's health and may in future result on communicable and non-communicable diseases [14]. Studies that involved assessing whether food products conformed to sanitary-epidemiologic requirements and ranking food products as per potential health risks they might cause have been accomplished in Moscow, Perm region, Primorye, Samara region, Orenburg region, Voronezh region, Tatarstan, Bashkortostan, etc. [4, 15-20]. This situation is typical not only for Russia but also for such developed countries as Sweden, the USA, Italy, France, Germany, etc. Although consumers in these countries are offered quite a wide range of FPs, morbidity caused by contaminated FPs is also rather high there [21-31]. But still, we haven't been able to find any works that focused not only on determining regional peculiarities of food products contamination but also on further ranking hazards and potential health risks that might occur due to FPs consumption. Scientific substantiation provided for periodicity and necessary volumes of sampling during scheduled inspections is another vital practical task.

Aim, in this study, was to reveal priority food products as per health risks they cause for population due to microbiological and chemical contamination. As an example we took a region located in the Far East Federal District; the region was a border one and there were certain regional peculiarities in nutrition structure and food products contamination there.

Data and methods. Data on food products contamination were provided by regional information funds within social and hygienic monitoring system of Buryatiya Region office of Federal Service for Surveillance over Consumer Rights Protection and Human Wellbeing, and the Center for Hygiene and Epidemiology, Buryatiya Regional Office. We analyzed research results obtained in 2010-2019 via laboratory tests that were performed on 
157,440 food products samples collected randomly on consumer markets in Buryatiya. 89,921 samples were tested as per microbiological parameters; 27,266, sanitary-chemical ones; 16,460, parasitological ones; 17,974, physical and chemical ones; 1,204, radiological ones; 3,872 samples were tested to reveal any GMO traces in them, and 741 were tested in order to detect antibiotics in them. Results obtained via laboratory examinations were estimated according to the Customs Union Technical Regulations ${ }^{2,3,4,5,6}$. We calculated per cent and a share of examinations with results deviating from epidemiologic standards; shares were calculated from the overall number of examinations over each year and average value for 5-year periods (2010-2014 and 2015-2019).

Potential risks of damage to health due to people consuming specific food products (FPs) $\left(R_{\text {food }}^{1}\right)$ were calculated as per formulas $(1,2$, 3) basing on data obtained from state departmental statistical reports, Form No. 18 «Data on a sanitary situation in an RF region» (section 8 «Hygienic characteristics of food raw materials and food products», issued in Buryatiya in 2017-2019; and "Consumption of basic food products by the population in the RF» state bulletin, section with data on Buryatiya. Health risks were estimated according to the Methodical guidelines ${ }^{7}$.

$$
R_{\text {food }}^{1}=\sum_{i}\left(p_{i}^{1} \cdot u_{i}^{1}\right) \cdot W
$$

where $p_{i}^{1}$ is frequency (probability) that obligatory safety requirements to FPs will be violated as per i-th hazard factor during one inspection; $u_{i}^{1}$ is relative damage to health caused by violated sanitary-epidemiologic requirements to i-th hazard factor of FPs according to Appendix No. 3 to the Methodical guidelines;

$W$ is a coefficient that characterizes regional peculiarities related to various FPs consumption.

$$
p^{1}{ }_{i}=m_{i} / n_{i}
$$

where $m_{i}$ is a number of FPs examinations per year with results showing that $\mathrm{i}$-th factor deviates from the standards;

$n_{i}$ is an overall number of $\mathrm{i}$-th factor examinations per year.

$$
W=V / V_{\mathrm{RF}}
$$

where $V$ is actual annual FPs consumption per one person living in Buryatiya (kg/year, L/year, units/year);

$V_{\mathrm{RF}}$ is average annual FPs consumption per one person in Russia (kg/year, L/year, units/year).

Research results were statistically processed with «Statistica v. 10.0» software package according to conventional procedures. Results were given as simple means with $95 \%$ confidence interval (CI). Comparisons were accomplished as per Student's t-test for the above given 5-year periods.

Results and discussion. Over the analyzed period, namely 2010-2019, in Buryatiya a share of FPs deviating from hygienic standards as per microbiological parameters amounted to $4.06 \%$ on average $(3.86 ; 4.26)$; as per sanitary-chemical parameters, $4.71 \%$ $(4.09 ; 5.33)$; as per parasitological parame-

\footnotetext{
${ }^{2}$ CUTR 021/2011. On food products safety. KODEKS: an electronic fund for legal and reference documentation. Available at: http://docs.cntd.ru/document/902320560 (30.09.2020) (in Russian).

${ }^{3}$ CUTR 023/2011. Technical regulations for juice products made of fruit and vegetables. KODEKS: an electronic fund for legal and reference documentation. Available at: http://docs.cntd.ru/document/902320562 (30.09.2020) (in Russian).

${ }^{4}$ CUTR 024/2011. Technical regulations for butter and fat products. KODEKS: an electronic fund for legal and reference documentation. Available at: http://docs.cntd.ru/document/902320571 (30.09.2020) (in Russian).

${ }^{5}$ CUTR 033/2013. On safety of milk and milk products. KODEKS: an electronic fund for legal and reference documentation. Available at: http://docs.cntd.ru/document/499050562 (30.09.2020) (in Russian).

${ }^{6}$ CUTR 034/2013. On safety of meat and meat products. KODEKS: an electronic fund for legal and reference documentation. Available at: http://docs.cntd.ru/document/499050564 (30.09.2020) (in Russian).

${ }^{7}$ MR. Classification of food products distributed on the market as per risks of damage to health and property losses borne by consumers used for organizing scheduled control and surveillance activities. Approved by the Order issued by Rospotrebnadzor on January 18, 2016 No. 16. Available at: http://base.garant.ru/71313192/53f89421bbdaf741eb2d1ecc4ddb4c33/ (30.09.2020) (in Russian).
} 
ters, $0.10 \%(0.07 ; 0.14)$; as per physicalchemical parameters, $7.57 \%(6.92 ; 8.22)$; antibiotics, $0.40 \%(0.17 ; 0.64)$. Inspections didn't reveal any GMO contents exceeding $0.9 \%$ or radioactive substances in concentrations higher than hygienic standards. There was a stable number of FPs samples that didn't conform to relevant regulations (Table 1).

Overall, there were no statistical discrepancies in a number of FPs samples containing chemical or microbiological contaminants in 2015-2019 against 2010-2014 ( $p>0.05)$. The only exceptions were 2 parameters, namely, shares of FPs samples deviating from hygienic standards as per sanitary-chemical and physical-chemical parameters where statistical discrepancies were authentic $(p \leq 0.01)$.

When analyzing results of FPs assessment as per sanitary-chemical parameters over a 10 -year period, we revealed that a peculiar feature was FPs deviating from hygienic standards due to fruits and vegetables being contaminated with nitrates (potatoes, vegetables and melons). In 2010-2019 nitrates contents in these products were higher than hygienic standards on average in $5.55 \%$ (5.06; 6.05). Specific share of samples with elevated nitrates contents went down by 1.47 times in 2015-2019 against 2010-2014, from $6.37 \%(5.63 ; 7.12)$ to $4.32 \%(3.92$; 4.72); however, these discrepancies were not statistically significant $(p>0.05)$.

There were no FPs samples deviating from hygienic standards as per other sanitarychemical parameters detected over the analyzed period. The only exceptions were the last two years when inspections revealed sporadic elevated toxic $\mathrm{Pb}$ and $\mathrm{Cd}$ contents in FPs. Average value of this parameter amounted to $0.05 \%$ in 2010-2019. Sporadic deviations from hygienic standards were detected in 2018 in «biologically active additives» FPs category in 2018, $0.16 \%$ of the overall number of examined samples; in 2019 there were $0.15 \%$ samples of «milk and milk products» deviating from hygienic standards as per this parameter. Accordingly, these small values allow treating these revelations as «accidental ones».

There was 1.75 times decrease in a share of iodized salt with iodine contents being lower than stated by a manufacturer in 2015-2019 against 2010-2014; it amounted to $2.0 \%$ (1.85; $2.15)$ and $3.49 \%(29.2 ; 4.06)$ accordingly but discrepancies were not statistically significant $(p>0.05)$.

Table 1

Results of food products examinations in 2010-2019

\begin{tabular}{|c|c|c|c|c|}
\hline \multirow[t]{2}{*}{ Parameters } & \multicolumn{3}{|c|}{$\begin{array}{l}\text { Percent of samples deviating from hygienic standards } \\
\text { (simple means and CI), \% }\end{array}$} & \multirow{2}{*}{$\begin{array}{c}\text { Statistical } \\
\text { significance of } \\
\text { discrepancies }(p)\end{array}$} \\
\hline & $2010-2014$ & $2015-2019$ & $2010-2019$ & \\
\hline $\begin{array}{l}\text { Sanitary-chemical parameters } \\
\text { including }\end{array}$ & $\begin{array}{c}5.97 \\
(5.33 ; 6.61)\end{array}$ & $\begin{array}{c}2.57 \\
(2.43 ; 2.71) \\
\end{array}$ & $\begin{array}{c}4.71 \\
(4.09 ; 5.33)\end{array}$ & $p \leq 0.01$ \\
\hline $\begin{array}{l}\text { Heavy metals } \\
(\mathrm{Pb}, \mathrm{As}, \mathrm{Cd}, \mathrm{Hg})^{*}\end{array}$ & 0.00 & $\begin{array}{c}0.08 \\
(0.05 ; 0.12)\end{array}$ & $\begin{array}{c}0.05 \\
(0.01 ; 0.08)\end{array}$ & $p>0.05$ \\
\hline Iodine & $\begin{array}{c}3.49 \\
(2.92 ; 4.06)\end{array}$ & $\begin{array}{c}2.0 \\
(1.85 ; 2.15)\end{array}$ & $\begin{array}{c}2.79 \\
(2.49 ; 3.09)\end{array}$ & $p>0.05$ \\
\hline Nitrates & $\begin{array}{c}6.37 \\
(5.63 ; 7.12)\end{array}$ & $\begin{array}{c}4.32 \\
(3.92 ; 4.72)\end{array}$ & $\begin{array}{c}5.55 \\
(5.06 ; 6.05)\end{array}$ & $p>0.05$ \\
\hline Physical-chemical parameters & $\begin{array}{c}8.89 \\
(8.24 ; 9.55)\end{array}$ & $\begin{array}{c}5.43 \\
(5.21 ; 5.66)\end{array}$ & $\begin{array}{c}7.57 \\
(6.92 ; 8.22)\end{array}$ & $p \leq 0.01$ \\
\hline Microbiological parameters & $\begin{array}{c}3.98 \\
(3.67 ; 4.29)\end{array}$ & $\begin{array}{c}4.15 \\
(3.92 ; 4.38)\end{array}$ & $\begin{array}{c}4.06 \\
(3.86 ; 4.26)\end{array}$ & $p>0.05$ \\
\hline $\begin{array}{l}\text { Pathogenic microorganisms in- } \\
\text { cluding Salmonellas }\end{array}$ & $\begin{array}{c}0.17 \\
(0.13 ; 0.21)\end{array}$ & $\begin{array}{c}0.31 \\
(0.20 ; 0.41)\end{array}$ & $\begin{array}{c}0.23 \\
(0.13 ; 0.34)\end{array}$ & $p>0.05$ \\
\hline Parasitological parameters & $\begin{array}{c}0.18 \\
(0.12 ; 0.24)\end{array}$ & $\begin{array}{c}0.02 \\
(0.00 ; 0.05)\end{array}$ & $\begin{array}{c}0.10 \\
(0.07 ; 0.14)\end{array}$ & $p>0.05$ \\
\hline
\end{tabular}

$\mathrm{N}$ o t e : * means that examinations revealed Pband Cd contents. 
Over recent years closer attention has been paid to testing whether food products conform to requirements fixed in regulatory documents as per physical-chemical parameters. A specific share of FPs that deviated from hygienic standards as per this parameter amounted to $5.43 \%$ on average in 2015-2019 $(5.21 ; 5.66)$ and it was authentically 1.64 times lower than in previous 5 years when it amounted to $8.89 \%$ $(8.24 ; 9.55)(p \leq 0.01)$.

Microbiological FPs contamination didn't change in the compared periods. Thus, in 2010-2014 a share of FPs that deviated from hygienic standards as per microbiological parameters amounted to $3.98 \%(3.67 ; 4.29)$; in $2015-2019,4.15 \%(3.92 ; 4.38)$ and these discrepancies were not statistically significant $(p>0.05)$. High specific weight of FPs samples deviating from hygienic standards as per microbiological parameters was detected in several product groups over the examined years; thus, it amounted to $9.53 \%$ (8.76; 10.31 ) in «milk and milk products» group; $6.88 \%(5.96 ; 7.80)$; «fish, non-fish hunting objects and products made of them»; $6.21 \%$ $(3.25 ; 9.18)$, «fruits and vegetables»; $5.89 \%$ (4.98; 6.81), «alcoholic beverages»; $5.79 \%$ (5.52; 6.07), «bakery and confectionary»; $4.96 \%(4.72 ; 5.20)$, «meat and meat products»; $4.90 \%(3.96 ; 5.83)$, «poultry, eggs, and products made of them»; $3.32 \%(3.09 ; 3.55)$, «culinary products». Average parameters authentically increased in 4 FPs groups in the $2^{\text {nd }}$ period against the $1^{\text {st }} 5$ years, namely, they grew by 3.53 times in "fruits and vegetables» group; by 3.0 times, «poultry, eggs, and products made of them»; by 1.82 times, in «fish, non-fish hunting objects and products made of them» and «biologically active additives» (BAA) (Table 2). There was no authentically significant increase or decrease in other FPs groups.

There was a slight increase in a share of FPs samples that deviated from hygienic standards as per contents of pathogenic microorganisms over the analyzed period as it amounted to $0.31 \%(0.20 ; 0.41)$ in $2015-2019$ against $0.17 \%(0.13 ; 0.21)$ in $2010-2014$.

Table 2

Results of microbiological inspections of specific food product groups over 2010-2019

\begin{tabular}{|c|c|c|c|c|}
\hline \multirow{2}{*}{$\begin{array}{l}\text { Food raw materials } \\
\text { and food products }\end{array}$} & \multicolumn{3}{|c|}{$\begin{array}{l}\text { Percent of samples deviating from hygienic standards } \\
\text { (simple means and } \mathrm{CI} \text { ), \% }\end{array}$} & \multirow{2}{*}{$\begin{array}{l}\text { Statistical significance } \\
\text { of discrepancies }(p)\end{array}$} \\
\hline & $2010-2014$ & $2015-2019$ & $2010-2019$ & \\
\hline Meta and meat products & $\begin{array}{c}4.73 \\
(4.26 ; 5.20) \\
\end{array}$ & $\begin{array}{c}5.35 \\
(4.81 ; 5.89) \\
\end{array}$ & $\begin{array}{c}4.06 \\
(3.93 ; 4.19) \\
\end{array}$ & $p>0.05$ \\
\hline $\begin{array}{l}\text { Poultry, eggs, and products made } \\
\text { of them }\end{array}$ & $\begin{array}{c}2.52 \\
(1.94 ; 3.10)\end{array}$ & $\begin{array}{c}7.55 \\
(5.06 ; 10.04)\end{array}$ & $\begin{array}{c}4.90 \\
(3.96 ; 5.83)\end{array}$ & $p \leq 0.01$ \\
\hline Milk and milk products & $\begin{array}{c}10.56 \\
(8.52 ; 12.59)\end{array}$ & $\begin{array}{c}8.36 \\
(7.41 ; 9.30)\end{array}$ & $\begin{array}{c}9.53 \\
(8.76 ; 10.31)\end{array}$ & $p>0.05$ \\
\hline $\begin{array}{l}\text { Fish, non-fish hunting objects } \\
\text { and products made of them }\end{array}$ & $\begin{array}{c}5.25 \\
(4.37 ; 6.13) \\
\end{array}$ & $\begin{array}{c}9.55 \\
(7.19 ; 11.90) \\
\end{array}$ & $\begin{array}{c}6.88 \\
(5.96 ; 7.80) \\
\end{array}$ & $p \leq 0.01$ \\
\hline Bakery and confectionary & $\begin{array}{c}6.22 \\
(5.75 ; 6.70)\end{array}$ & $\begin{array}{c}5.12 \\
(4.51 ; 5.72) \\
\end{array}$ & $\begin{array}{c}5.79 \\
(5.52 ; 6.07)\end{array}$ & $p>0.05$ \\
\hline Fruits and vegetables & $\begin{array}{c}3.92 \\
(2.63 ; 5.21) \\
\end{array}$ & $\begin{array}{c}13.82 \\
(6.37 ; 21.27) \\
\end{array}$ & $\begin{array}{c}6.21 \\
(3.25 ; 9.18)\end{array}$ & $p \leq 0.01$ \\
\hline Culinary products & $\begin{array}{c}2.92 \\
(2.34 ; 3.49)\end{array}$ & $\begin{array}{c}3.48 \\
(3.11 ; 3.86)\end{array}$ & $\begin{array}{c}3.32 \\
(3.09 ; 3.55)\end{array}$ & $p>0.05$ \\
\hline Butter and fats & $\begin{array}{c}1.46 \\
(0.83 ; 2.10)\end{array}$ & $\begin{array}{c}2.51 \\
(1.67 ; 3.35)\end{array}$ & $\begin{array}{c}1.99 \\
(1.63 ; 2.35)\end{array}$ & $p>0.05$ \\
\hline Alcoholic beverages & $\begin{array}{c}4.97 \\
(3.56 ; 6.37) \\
\end{array}$ & $\begin{array}{c}7.14 \\
(4.85 ; 9.44) \\
\end{array}$ & $\begin{array}{c}5.89 \\
(4.98 ; 6.81) \\
\end{array}$ & $p>0.05$ \\
\hline Non-alcoholic beverages & $\begin{array}{c}0.84 \\
(0.65 ; 1.04)\end{array}$ & $\begin{array}{c}1.93 \\
(0.90 ; 2.95)\end{array}$ & $\begin{array}{c}1.17 \\
(0.82 ; 1.53) \\
\end{array}$ & $p>0.05$ \\
\hline BAA & 0 & $\begin{array}{c}3.18 \\
(1.36 ; 5.0)\end{array}$ & $\begin{array}{c}2.81 \\
(-1.09 ; 6.71)\end{array}$ & $p \leq 0.01$ \\
\hline
\end{tabular}


Table 3

Dependence between percentage of non-standard samples and a number of observations by parameters (in 2010-2019)

\begin{tabular}{|l|c|c|c|}
\hline \multicolumn{1}{|c|}{ Parameters $(y)$} & $\begin{array}{c}\text { Dependence on a number } \\
\text { of examinations }(x)\end{array}$ & Approximation coefficient & $p$ \\
\hline Sanitary-chemical & $y=0.09 x-126.55$ & $R^{2}=0.89$ & $=0.32$ \\
\hline Physical-chemical & $y=0.12 x-86.47$ & $R^{2}=0.85$ & $=0.33$ \\
\hline Microbiological & $y=0.03 x+75.08$ & $R^{2}=0.24$ & $=0.10$ \\
\hline Salmonella* & $y=0.9928 x-0.2543$ & $R^{2}=0.99$ & $=0.35$ \\
\hline Parasitological & $y=0.01 x-18.35$ & $R^{2}=0.37$ & $=0.02$ \\
\hline
\end{tabular}

$\mathrm{N}$ o t e : * means a number among FP samples containing pathogenic microorganisms in elevated quantities deviating from hygienic standards.

5 FPs groups were the most hazardous in this respect as they contained pathogenic microorganisms in quantities being higher than hygienic standards. These groups were «poultry, eggs, and products made of them», $3.77 \%$ (2.81; 4.73); «fruits and vegetables», $1.62 \%$ $(-2.51 ; 5.75)$; «meat and meat products», $0.85 \%(0.76 ; 0.94)$; «culinary products», $0.07 \%(0.05 ; 0.09)$; «bakery and confectionary», $0.05 \%(0.04 ; 0.07)$.

We analyzed dynamics in these parameters and revealed an increase in a share of FPs samples with pathogenic microorganisms' contents deviating from hygienic standards in 2015-2019 against the previous 5 years. The greatest increase was revealed in «poultry, eggs and products made of them» FPs group and amounted to 3.5 times. A share of such samples grew from 0 to $6.78 \%$ in «fruits and vegetables» FPs group. The situation with pathogenic microorganisms was rather stable in «meat and meat products» FPs group and «culinary products» FPs group and there were no authentic discrepancies between the compared periods: $0.77 \%(0.64 ; 0.89)$ in $2010-2014$ and $1.0 \%$ $(0.76 ; 1.23)$ in $2015-2019 ; 0.06 \%(0.01$; $0.11)$ in $2010-2014$ and $0.08 \%(0.04 ; 0.12)$ in 2015-2019 accordingly.

It was established that in 2015-2019 a share of FPs that contained salmonella amounted for $99.17 \%(98.73 ; 99.60)$ among FPs samples with detected pathogenic microorganisms in them that were not allowed according to hygienic standards; it was higher than the same parameter in 2010-2014 when it amounted to $96.34 \%(94.71 ; 97.98)$.

We applied linear approximation to analyze results obtained via FPs examinations aimed at revealing their conformity with hygienic standards as per sanitary-chemical, microbiological, parasitological, and physical-chemical parameters in 2010-2019. It allows predicting frequency of non-standard samples. As it is shown in Table 3, approximation coefficient is close to 1.0 for sanitary-chemical and physical-chemical parameters and it indicates that the more FPs samples are examined the more samples that deviate from hygienic standards are to be expected.

In its turn $R^{2}=0.24$ and 0.37 for microbiological and parasitological parameters accordingly and it means there is no such dependence. It confirms that detection of FPs samples that deviate from hygienic standards as per microbiological and parasitological parameters depends not only on overall number of FPs examinations as per these parameters. We can predict that a further growth in a number of examinations aimed at estimating FPs as per these criteria during scheduled inspections will not result in more frequently detected violations of hygienic requirements. Approximation coefficient is practically equal to 1.0 for salmonella detection. It means there is a direct correlation with a greater number of FPs samples containing pathogenic microorganisms in quantities deviating from hygienic standards and we can predict more fre- 
quent detection of samples containing this pathogen.

Our next task was to assign FPs to a certain category as per risks of causing damage to consumers' health taking into account regional peculiarities regarding food consumption. To do that, we calculated risks of damage to health due to people consuming food products that didn't conform to safety requirements. The results are given in Table 4 and compared with data obtained for the country as a whole [14].

These data indicate that risks associated with chemical contamination are insignificant excluding FPs contamination with nitrates. When it comes down to microbiological contamination, there seems to be a stable situation with it on the consumer market in Buryatiya but in spite of it certain FPs groups are to be paid closer attention, namely «poultry, eggs and products made of them» and «fruits and vegetables». There was a 3.5 times growth, fromc $1.75 \cdot 10^{-2}$ in $2010-2014$ to $6.12 \cdot 10^{-2}$ in 2015-2019 in average probability that obligatory safety requirements to poultry products might be violated due to elevated quantities of pathogenic microorganisms; the same parameters grew also for fruit and vegetables, from 0 to $6.78 \cdot 10^{-2}$ accordingly. Our analysis of approximation coefficients allowed us to predict greater frequency of detected salmonella due to growth in number of FPs samples containing pathogenic microorganisms in quantities exceeding hygienic standards.

We should note that there was a change in the structure of detected serologic salmonella types over the second 5-year period as there was a slight growth in quantity of detected salmonella belonging to group $\mathrm{S}$ (S. Infantis). It is well in line with data obtained by P. Antunes [et al.] on a significant decrease in S. Enteritidis quantities and a growing number of serotypes that are more adaptable and more resistant to antibiotics, such as S. Infantis, S. Kentucky etc. [32]. But at the same time, according to data given by T. Oscar in a model he developed, prevalence of salmonella didn't correlate $(r=-0.39 ; p=0.21)$ with a risk that salmonellosis might occur. That risk was influenced by other factors such as quantity of salmonella; their virulence; how often and to what extent poultry meat was poorly cooked;

Table 4

Classification of food products, according to health risks due to consumption by the population living in Republic of Buryatiya

\begin{tabular}{|c|c|c|c|c|}
\hline \multirow[b]{2}{*}{$\begin{array}{l}\text { Food products } \\
\text { group }\end{array}$} & \multicolumn{3}{|c|}{ Buryatiya } & \multirow[b]{2}{*}{$\begin{array}{l}\text { Potential health risk cate- } \\
\text { gory / Hazard category for } \\
\text { damage to health in the } \\
\text { Russian Federation [14] }\end{array}$} \\
\hline & $\begin{array}{l}\text { coefficient that char- } \\
\text { acterizes regional } \\
\text { consumption }(W)\end{array}$ & $\begin{array}{l}\text { potential } \\
\text { health } \\
\text { risk }(R)\end{array}$ & $\begin{array}{l}\text { Potential health risk cate- } \\
\text { gory / Hazard category } \\
\text { for damage to health } \\
\text { in the examined region }\end{array}$ & \\
\hline $\begin{array}{l}\text { Poultry, eggs and } \\
\text { products made of them }\end{array}$ & 0.88 & $1.54 \cdot 10^{-2}$ & High / 2 category & Significant / 3 category \\
\hline Bakery and confectionary & 1.16 & $3.97 \cdot 10^{-3}$ & Significant / 3 category & High / 2 category \\
\hline Fish and fish products & 0.91 & $2.82 \cdot 10^{-3}$ & Significant / 3 category & High / 2 category \\
\hline Milk and milk products & 0.78 & $1.58 \cdot 10^{-3}$ & Significant / 3 category & Significant / 3 category \\
\hline Meat and meat products & 0.75 & $7.21 \cdot 10^{-5}$ & Average / 4 category & Significant / 3 category \\
\hline Potato & 1.44 & $2.76 \cdot 10^{-4}$ & Average / 4 category & Moderate / 5 category \\
\hline Culinary products* & 0.94 & $2.46 \cdot 10^{-4}$ & Average / 4 category & Significant / 3 category \\
\hline Butter and fats & 0.80 & $2.17 \cdot 10^{-4}$ & Average / 4 category & Moderate / 5 category \\
\hline Vegetables & 0.70 & $1.30 \cdot 10^{-5}$ & Moderate / 5 category & Moderate / 5 category \\
\hline Canned food* & 1.0 & $1.44 \cdot 10^{-5}$ & Moderate / 5 category & Significant / 3 category \\
\hline $\mathrm{BAA}^{*}$ & 0.70 & $1.41 \cdot 10^{-5}$ & Moderate / 5 category & Moderate / 5 category \\
\hline
\end{tabular}

$\mathrm{N}$ ot e : * means that $\mathrm{R}$ as potential health risk caused by people consuming a specific food product is calculated as per mean values obtained from Section 8 in the Statistical Report Form No. 18 over 2017-2019. 
consumer behavior when cooking and eating poultry meat; and a particular person's resistance to the pathogen. All this combined determines a necessity to apply a more integral approach involving technological and behavioral risks assessment and is in line with data obtained by E. Lambertinia [et al.], Y. Cui [et al.] [33-35].

Having calculated potential health risks caused by people consuming a specific food products we established that there were no food products categorized as extremely risky in Buryatiya, just as it was the case with the country in general [14]. But still, there were certain difference detected on the regional consumer market against the data obtained for the country as a whole. Thus, «poultry, eggs and products made of them» FPs group caused high health risks due to microbiological contamination with pathogens (detected salmonella), whereas there were no such risks detected in the country on average. Given that, this product group is subject to obligatory control in $100 \%$ cases as per a list of factors determined via previous inspections performed at economic entities. Bakery and confectionary, fish and fish products that were determined as causing high health risks in the Russian Federation caused only significant health risks on the examined regional market. Besides, significant risks were caused by «milk and milk products» FPs group. Average risks that required control in $50 \%$ cases during scheduled inspections performed at economic entities included such FPs groups as «meat and meat products», «potato», «butter and fats», and «culinary products». According to calculated data, vegetables, canned food and BAA cause only moderate risks and require control in $10 \%$ cases. The remaining products groups caused low health risks and were assigned into FPs category that required only documentary control in case there were time and labor resources to perform it.

Conclusion. We accomplished complex assessment of FPs quality and safety; it allowed us to classify food products as per health risks they caused with determining certain priorities. The results are vital for public health preservation in Buryatiya. In case there is a growth in number of targeted FPs examinations, we predict more frequently detected violations of hygienic requirements as per sanitary-chemical and physical-chemical parameters. The greatest health risk for population is caused by microbiological contamination of poultry products distributed on the regional market.

Given that, it is necessary to continue monitoring activities together with veterinary services aimed at providing food products safety and animals' health; it is also necessary to pursue a «restraining strategy» aimed at minimizing microbiological contamination and reducing salmonella transfer along food chains (from primary manufacture to consumption).

Food products trade on the global scale involves growing consumer demand for poultry meat on regional markets, especially in countries with low and middle incomes. This, together with this products being widely promoted by mass media, can make for low quality and potentially hazardous products penetrating the consumer market in Buryatiya; in future it can result in a deteriorating epidemiological situation.

Funding. The present work was accomplished within a budgetary scientific research program.

Conflict of interest. The authors declare there is no any conflict of interests.

\section{References}

1. Tutel'yan V.A., Nikityuk D.B., Sharafetdinov Kh.Kh. Zdorovoe pitanie - osnova zdorovogo obraza zhizni i profilaktiki khronicheskikh neinfektsionnykh zabolevanii [Healthy nutrition as a basis for healthy lifestyle and prevention of chronic non-communicable diseases]. Zdorov'e molodezhi: 
novye vyzovy i perspektivy. Moscow, OOO IPTs Nauchnaya kniga Publ., 2019, pp. 203-227 (in Russian).

2. Popova A.Yu., Gurvich V.B., Kuz'min S.V., Mishina A.L., Yarushin S.V. Modern issues of the health risk assessment and management. Gigiena i sanitariya, 2017, vol. 96, no. 12, pp. 1125-1129 (in Russian).

3. Bertolatti D., Theobald C. Food safety and risk analysis. Encyclopedia of Environmental Health, 2019, pp. 57-67. DOI: 10.1016/B978-0-12-409548-9.11821-4

4. Sazonova O.V., Gorbachev D.O., Nurdina M.S., Kupaev V.I., Borodina L.M., Gavryushin M.Yu., Frolova O.V. Hygienic characteristics of actual nutrition of the working population Samara region. Voprosy pitaniya, 2018, vol. 87, no. 4, pp. 32-38 (in Russian).

5. Belova L.V., Pil'kova T.Yu., Fedotova I.M. Obespechenie kachestva i bezopasnosti pishchevykh produktov $\mathrm{v}$ nastoyashchii period [Providing quality and safety of food products nowadays]. Zdorov'e - osnova chelovecheskogo potentsiala: problemy i puti ikh resheniya, 2018, no. 2, pp. 754-759 (in Russian).

6. Litvinova O.S. Hygienic assessment of nutrition structure of population of the Russian Federation. Zdorov'e naseleniya i sreda obitaniya, 2016, vol. 278, no. 5, pp. 11-14 (in Russian).

7. Baglushkina S.Yu., Efimova N.V., Tarmaeva I.Yu. The structure of the adult nutrition and risk of illness connected with infrigement of nutrition. Zdorov'e naseleniya i sreda obitaniya, 2015, vol. 267, no. 6, pp. 23-25 (in Russian).

8. Mozaffarian D. Dietary and Policy Priorities for Cardiovascular Disease, Diabetes, and Obesity: A Comprehensive Review. Circulation, 2016, vol. 2, no. 133, pp. 187-225. DOI: 10.1161/CIRCULATIONAHA.115.018585

9. Shur P.Z., Zaitseva N.V., Khotimchenko S.A., Fedorenko E.V., Sychik S.I., Fokin V.A., Suvorov D.V., Zelenkin S.E. On the issue of establishing acceptable daily intake of chemical substances in food products according to health risk criteria. Gigiena i sanitariya, 2019, vol. 98, no. 2, pp. 189-195 (in Russian).

10. Serafimovich A.E., Prosekov A.Yu. Food security: international legal aspects and Russian law enforcement practice. Pravo. Zhurnal Vysshei shkoly ekonomiki, 2018, no. 4, pp. 235-253 (in Russian).

11. WHO. News bulletin. August 2019. Food safety. Social aspects of public health. Available at: https://cyberleninka.ru/article/n/voz-informatsionnyy-byulleten-avgust-2019-bezopasnost-produktov-pitaniya (30.09.2020).

12. Song Y.-H., Yu H.-Q., Tan Y.-C., Lv W., Fang D.-H., Liu D. Similarity matching of food safety incidents in China: Aspects of rapid emergency response and food safety. Food Control, 2020, no. 115 , pp. 107275 . DOI: $10.1016 /$ j.foodcont.2020.107275

13. Poznyakovskii V.M. Nutrition evolution and nutriom formation of the modern human. Food industry, 2017, vol. 4, no. 3, pp. 5-12 (in Russian).

14. Zaitseva N.V., Ustinova O.Yu., Sboev A.S. Medical and preventive technologies for risk management of health problems associated with exposure to environmental factors. Gigiena $i$ sanitariya, 2016, vol. 95, no. 1, pp. 17-22 (in Russian).

15. Andreeva E.E. Application of a risk-oriented model for the redistribution of staffing resources of the office of service for supervision of consumer rights protection and human welfare in the city of Moscow. Gigiena i sanitariya, 2018, vol. 97, no. 5, pp. 441-444 (in Russian).

16. Kislitsyna L.V. Assessment of the potential risk of harm to health due use community food for the Primorsky region of Russia. Zdorov'e. Meditsinskaya ekologiya. Nauka, 2016, vol. 66, no. 3, pp. 188-192 (in Russian).

17. Boev V.M., Borshchuk E.L., Kryazhev D.A., Savina E.K. Malignant tumors of the rectum, rectosigmoid connections and colon and hygienic evaluation of carcinogenic chemicals entering the oral route. Zdorov'e naseleniya i sreda obitaniya, 2017, vol. 291, no. 6, pp. 13-17 (in Russian).

18. Klepikov O.V., Khatuaev R.O., Istomin A.V., Rumyantseva L.A. Regional features of food standards and health risks associated with chemical contamination of food. Gigiena i sanitariya, 2016, vol. 95, no. 11, pp. 1086-1091 (in Russian). 
19. Mukhutdinova G.M., Mukhametshin I.R., Patyashina M.A., Avdonina L.G., Rybachenok T.M., Filippova S.Yu., Imamov A.A. The role of food to achieve optimal health. Sciences of Europe, 2018, vol. 28, no. 1, pp. 19-24 (in Russian).

20. Daukaev R.A., Larionova T.K., Allayarova G.R., Adieva G.F., Afon'kina S.R., Fazlyeva A.S., Usmanova E.N., Kurilov M.V. Territories ranking of Bashkortostan on the level of food products contamination. Zdorov'e naseleniya i sreda obitaniya, 2019, vol. 310, no. 1, pp. 24-27 (in Russian).

21. Wallace T.C., Frankenfeld C.L., Frei B., Shah A.V., Yu C.R., Van Klinken B.J., Adeleke M. Multivitamin/multimineral supplement use is associated with increased micronutrient intakes and biomarkers and decreased prevalence of inadequacies and deficiencies in middle-aged and older adults in the United States. J. Nutr. Gerontol. Geriatr., 2019, vol. 4, no. 38, pp. 307-328. DOI: 10.1080/21551197.2019.1656135

22. Yasuda H., Tsutsui M., Ando J., Inano T., Noguchi M., Yahata Y., Tanaka M. [et al.]. Vitamin B6 deficiency is prevalent in primary and secondary myelofibrosis patients. Int. J. Hematol., 2019, vol. 5, no. 110 , pp. 543-549. DOI: 10.1007/s12185-019-02717-8

23. Tarmaeva I.Yu., Efimova N.V., Khankhareev S.S., Bogdanova O.G. Features of actual nutrition of the adult population in republic of Buryatia in modern conditions. Voprosy pitaniya, 2018, vol. 87, no. 3, pp. 30-35 (in Russian).

24. Lappi V.M., Mottas A., Sundstrom J., Neal B., Lof M., Radholm K. A Comparison of the nutritional qualities of supermarket's own and regular brands of bread in Sweden. Nutrients, 2020, vol. 2, no. 4, pp. 1162. DOI: 10.3390/nu12041162

25. Melotto M., Brandl M.T., Jacob C., Jay-Russell M.T., Micallef S.A., Warburton M.L., Van Deynze A. Breeding crops for enhanced food safety. Frontiers in plant science, 2020, no. 11, pp. 428. DOI: $10.3389 /$ fpls.2020.00428

26. Iannetti L., Schirone M., Neri D., Visciano P., Acciari V.A., Centorotola G., Mangieri M.S. [et al.]. Listeria monocytogenes in poultry: Detection and strain characterization along an integrated production chain in Italy. Food microbiology, 2020, no. 91, pp. 103533. DOI: 10.1016/j.fm.2020.103533

27. Di Bella C., Traina A., Giosue C., Carpintieri D., Lo Dico G.M., Bellante A., Del Core M. [et al.]. Heavy metals and PAHs in meat, milk, and seafood from augusta area (southern Italy): contamination levels, dietary intake, and human exposure assessment. Frontiers in public health, 2020, no. 8, pp. 273. DOI: 10.3389/fpubh.2020.00273

28. Srour B., Fezeu L.K., Kesse-Guyot E., Alles B., Mejean C., Andrianasolo R.M., Chazelas E. [et al.]. Ultra-processed food intake and risk of cardiovascular disease: prospective cohort study (NutriNet-Sante). BMJ, 2019, vol. 29, no. 365, pp. 11451. DOI: 10.1136/bmj.11451

29. Gerson J.R., Driscoll C.T., Demers J.D., Sauer A.K., Blackwell B.D., Montesdeoca M.R., Shanley J.B., Ross D.S. Deposition of mercury in forests across a montane elevation gradient: Elevational and seasonal patterns in methylmercury inputs and production. Journal of geophysical researchbiogeosciences, 2017, vol. 8, no. 122, pp. 1922-1939. DOI: 10.1002/2016JG003721

30. Shariatifar N., Seilani F., Jannat B., Nazmara S., Arabameri M. The concentration and health risk assessment of trace elements in commercial soft drinks from Iran marketed. International journal of environmental analytical chemistry, 2020, $16 \mathrm{p}$.

31. Carraturo F., Libralato G., Esposito R., Galdiero E., Aliberti F., Amoresano A., Fontanarosa C., Trifuoggi M., Guida M. Metabolomic profiling of food matrices: Preliminary identification of potential markers of microbial contamination. Journal of food science, 2020, vol. 10, no. 85, pp. 3467-3477. DOI: 10.1111/1750-3841.15418

32. Antunes P., Mourao J., Campos J., Peixe L. Salmonellosis: the role of poultry meat. Clinical microbiology and infection, 2016, no. 22, pp. 110-121. DOI: 10.1016/j.cmi.2015.12.004

33. Oscar T. Salmonella prevalence alone is not a good indicator of poultry food safety. Risk analysis, 2020, no. 10, pp. 1111. DOI: 10.1111/risa.13563

34. Lambertini E., Ruzante J.M., Chew R., Apodaca V.L., Kowalcyk B.B. The public health impact of different microbiological criteria approaches for Salmonella in chicken parts. Microbial Risk Analysis, 2019, no. 12, pp. 44-59. DOI: 10.1016/j.mran.2019.06.002 
35. Cui Y., Guran H.S., Harrison M.A., Hofacre C.L., Alali W.Q. Salmonella levels in turkey neck skins, drumstick bones and spleens in relation to ground turkey. Journal of food protection, 2015, vol. 11, no. 78, pp. 1945-1953. DOI: 10.4315/0362-028X.JFP-15-240

Bogdanova O.G., Molchanova O.A., Tarmaeva I.Yu., Efimova N.V. Assessment and classification of food products as per health risks caused by chemical and microbiological contamination. Health Risk Analysis, 2021, no. 1, pp. 57-67. DOI: 10.21668/health.risk/2021.1.06.eng

Received: 22.10 .2020

Accepted: 07.02.2021

Published: 30.03.2021 
UDC 539.1

DOI: $10.21668 /$ health.risk/2021.1.07.eng

Research article

\title{
HEAVY METAL CONCENTRATION IN VEGETABLES AND THEIR POTENTIAL RISK FOR HUMAN HEALTH
}

\author{
A. Feseha ${ }^{1,2}$, A.K. Chaubey ${ }^{1}$, A. Abraha ${ }^{3}$ \\ ${ }^{1}$ Department of Physics, College of Natural \& Computational Sciences, Addis Ababa University, Addis Ababa, Ethiopia \\ ${ }^{2}$ Department of Physics, College of Natural \& Computational Sciences, Arba Minch University, Arba Minch, Ethiopia \\ ${ }^{3}$ Department of Physics, College of Natural and Computational Sciences, Samara University, Samara, Ethiopia
}

This study assesses heavy metal levels in the water, soil, and vegetables (swiss chard, lettuce, cabbage, collard green, tomato, green pepper, and carrot) irrigated with wastewater in Gamo, Ethiopia. The samples of soils, waters, and vegetables were randomly collected, processed, and analyzed for heavy metals using atomic absorption spectroscopy. The obtained results show that the mean concentrations of $\mathrm{Cd}$, $\mathrm{Cr}$, and $\mathrm{Ni}$ were the highest, and $\mathrm{Pb}, \mathrm{Zn}$, and $\mathrm{Cu}$ had the lowest concentration in irrigation waters. The levels of Cd in the Kulfo river area and Chamo Lake area and Cu in most of the farm soils were also found to be higher than the reference values. The study also revealed that the mean levels of Cd in most vegetables and $\mathrm{Cr}$ and $\mathrm{Pb}$ in some vegetables were higher than the maximum recommended limits set by the World Health Organization / Food and Agriculture Organization 2001. Among the vegetables, cabbage had the highest heavy metal content followed by Swiss-chard, carrot, tomato, collard green, green pepper, and lettuce. The hazard quotient obtained for $\mathrm{Cu}$, and $\mathrm{Ni}$ in all vegetable samples and $\mathrm{Cd}$ in some vegetable samples exceeded 1. It indicates that there are potential health risks to consumers. This study recommends regular monitoring over heavy metals contents in soils, waters, and foodstuffs to prevent their excessive accumulation in food chains.

Key words: heavy metals; pollution; vegetables; hazard quotient, risk assessment, safety, human health, FAAS.

Vegetables as reported by [1] are essential sources that provide people with a wide range of vital micronutrients. Several researchers observed that vegetable consumption could prevent several chronic noncommunicable diseases such as cardiovascular diseases, kidney, nervous as well as bone diseases. Vegetables also contribute substantially in providing a body with proteins, minerals, vitamins, fiber, and other nutrients which are usually in short supply in daily diets $[2,3]$. The recent trend indicates that there is an increasing awareness regarding nutritive value of vegetables to the extent that many people now prefer eating vegetables to meat [4]. Vegetables have been recognized to have some medical properties due to antioxidant and antimicrobial effects. Many of them were even documented to possess anti-diabetic, anti-inflammatory, and anti-hypertensive potential $[5,6]$.

But at the same time safety and quality of agricultural products to a great extent depends on a place where they are grown, especially in case there is a threat that toxicants, heavy metals included, can occur in the environment. Heavy metals being introduced into the environment through anthropogenic sources are a serious growing problem throughout the world [7-9]. Anthropogenic sources of heavy metal contaminants include domestic, industrial, agricultural, bush burning, fossil fuels burning, etc.

Water gets contaminated with heavy metals on certain territories practically unavoidably since there are natural reasons for it (rock

(c) Feseha A., Chaubey A.K., Abraha A., 2021

Abrham Feseha - Postgraduate student of the Department of Physical Sciences (e-mail: abrham.feseha@aau.edu.et; tel.: +251-111-239768; ORCID: https://orcid.org/0000-0001-5507-6588).

Ashok Kumar Chaubey - Academician, Doctor of Physical Sciences, Professor (e-mail: chaubeyak@aau.edu.et; tel.: +251-111-239768; ORCID: https://orcid.org/0000-0002-0536-0852).

Ataklti Abraha - Academician, Doctor of Physical Sciences, Assistance Professor (e-mail: atklt.physics@gmail.com; ORCID: https://orcid.org/0000-0001-8407-2113). 
erosion) and anthropogenic activities (industries, agriculture, and households). Wastewaters from mining, electric industry, dye works, and chemical laboratories often contain heavy metals in high concentrations including cadmium $(\mathrm{Cd})$, copper $(\mathrm{Cu})$, and lead $(\mathrm{Pb})$. Agricultural soils get contaminated with heavy metals due to irrigation with wastewaters and it is rather alerting since it can produce negative effects on people's health. A study was performed in Ghana that focused on water in irrigation systems used for growing cabbage, carrots, and lettuce that contained $\mathrm{Cd}$ and $\mathrm{Pb}$; the study revealed that $\mathrm{Cd}$ and $\mathrm{Pb}$ concentrations grew considerably together with a growth in irrigation water concentration. In most developing countries it is a usual practice to grow vegetables along rivers that flow through urban territories. Water in such rivers is often reported to be contaminated with heavy metals. An extent to which metals are absorbed by plants from water depends, among other things, on a plant itself and chemical structure of a contaminant, element concentration in soil. $\mathrm{pH}$, and interaction with other metals. Water gets contaminated with heavy metals mostly due to waste discharge from mining industry as well as from a wide range of other industries.

Heavy metals are found in soils in different chemical forms and it is closely connected to their solubility that directly depends on their mobility and biological availability. Soluble heavy metals easily penetrate plants. The highest concentrations in soils were detected for zinc $(113 \mathrm{mg} / \mathrm{kg})$, chromium $(47.8 \mathrm{mg} / \mathrm{kg})$, lead $(17.7 \mathrm{mg} / \mathrm{kg})$ and cadmium $(0.250 \mathrm{mg} / \mathrm{kg})$; they were detected on agricultural territories in Zivey, Burau, and Addis Ababa provinces. Heavy metals concentrations detected near Addis Ababa were the highest in comparison with Zivey province. It indicates that agricultural products are grown on territories where metals concentrations in soils occur due to natural reasons.

Some heavy metals such as $\mathrm{Fe}, \mathrm{Zn}, \mathrm{Cu}$, and Se are essential for people especially when they are in small quantities. However, heavy metals are non-biodegradable and therefore readily accumulate to toxic levels in biological media and produce negative effects on animals, plants, and humans when they exceed a certain threshold [9]. Other heavy metals such as $\mathrm{Pb}, \mathrm{As}, \mathrm{Cd}$, and $\mathrm{Hg}$ are toxic even in low concentrations and exposure to them results in certain health problems.

The human body can be easily contaminated by heavy metals such as $\mathrm{Ni}, \mathrm{Cd}, \mathrm{Cr}, \mathrm{Pb}$, and $\mathrm{Cu}$ through dietary exposure or exposure to the contaminated environment. Since fruits and vegetables can absorb heavy metal contents from the soil, even the same crops, fruits or vegetables, can contain minerals in different quantities depending on soils and a region where these plants are cultivated. The increased concentration of heavy metals is associated with the etiology of several diseases, especially cardiovascular, renal, and neurological disorders.

Cadmium is a non-essential element that occurs in foods and natural waters and it accumulates principally in the kidneys and liver. Cadmium causes acute and chronic poisoning, adverse effects on the kidneys, and liver, vascular and immune systems. Recently great attention has been paid to this element contents in water, soils, milk, food products and medicinal herbs and plants. Cadmium occurs on soils and plants most frequently from phosphate fertilizers, melting furnaces at nonferrous metallurgic enterprises, lead and zinc mines, discharges from industrial enterprises, and organic fuels burning.

Lead is a serious cumulative body poison that enters a body with air, water, and food and cannot be removed by washing fruits and vegetables.

Copper is an essential trace element required for proper health in a relevant quantity. Its high concentrations in fruits and vegetables can be harmful to human health and in the same way; low consumption can cause many symptoms like growth retardation, skin ailments, and gastrointestinal disorders.

Zinc is an essential element and an integral component in many coenzymes, essential for the synthesis of DNA, RNA, proteins, and insulin but toxic in high concentrations. 
People may get exposed to chromium via inhalation, drinking water consumption, or eating food containing chromium or even through skin contact. Exposure to elevated levels of chromium leads to skin irritation, ulceration, damage to circulatory and nerve tissues and it causes health problems. However, daily intake of this metal within a certain range of concentrations (up to $200 \mu \mathrm{g} /$ day) by human beings and animals is considered to be essential for carbohydrate \& lipid metabolism.

Analyzing and predicting consequences caused by pollution requires identifying and determining a number of potential risk sources, estimating a number of risk factors that come into contact with the human-environment boundaries; estimating levels of exposure via detecting routes of exposure to a target organism and quantifying health risks caused by this exposure. However, the fact that the contaminant levels exceed the permissible limits set by such regulatory agencies as the World Health Organization (WHO) does not always indicates there is a risk for human health. For this reason, the target hazard quotient (THQ) method designed by the United States Environmental Protection Agency (USEPA) for assessing potential health risks associated with long-term exposure to heavy metals was used to assess health risks in this study [9]. THQ that was equal to or greater than one $(1 \geq)$ indicated a health risk to exposed population.

Currently in Arba Minch Gamo-zone, Ethiopia there is no regulatory criterion of heavy metals in irrigation waters, soils \& vegetables. However, due to businesses' economic, industrial, and other development activities, heavy metals concentrations are increasing in irrigation waters, agricultural soils, vegetables, and crops that are grown in and outside the city. The farmlands and land spots along the river bank are intensely used in crops and vegetable production, but still, very little information is available regarding heavy metals contents in irrigation waters, soils, and vegetables. Therefore, the present investigation aims to quantify the concentration of various metals in soils and commonly grown vegetables irrigated with wastewater to calculate the daily intake rate of metals (DIR) basing on intake of particular vegetables by local population and to estimate hazards for human health related to heavy metals through the consumption of vegetables grown on four irrigational sites in Gamo, Ethiopia. The results will provide invaluable baseline data for further investigation of heavy metals accumulation in foodstuffs, thereby improving food safety and more efficient health protection for people who live on the examined territory.

Materials and methods. Arba Minch located at $6^{\circ} 2^{\prime} \mathrm{N} 37^{\circ} 33^{\prime} \mathrm{E}$ is one of a town in Gamo Gofa Zone, Southern Nations Nationalities and Peoples Region (SNNPR) regional state in Ethiopia found around $500 \mathrm{~km}$ away from Addis Ababa, Ethiopia's capital city. The town got its present name Arba Minch, meaning «40 springs» since it has 40 natural springs which are major tourist attractions (Figure). Kulfo River, Abaya Lake, and Chamo Lake are the water source for many inhabitants in the Arba Minch area for farmlands, for domestic activities, etc. The river and lakes have their source from the highlands in Gamo region which have experienced high levels of agricultural development. The farmlands where these lakes and river water were used for irrigation were selected for this study.

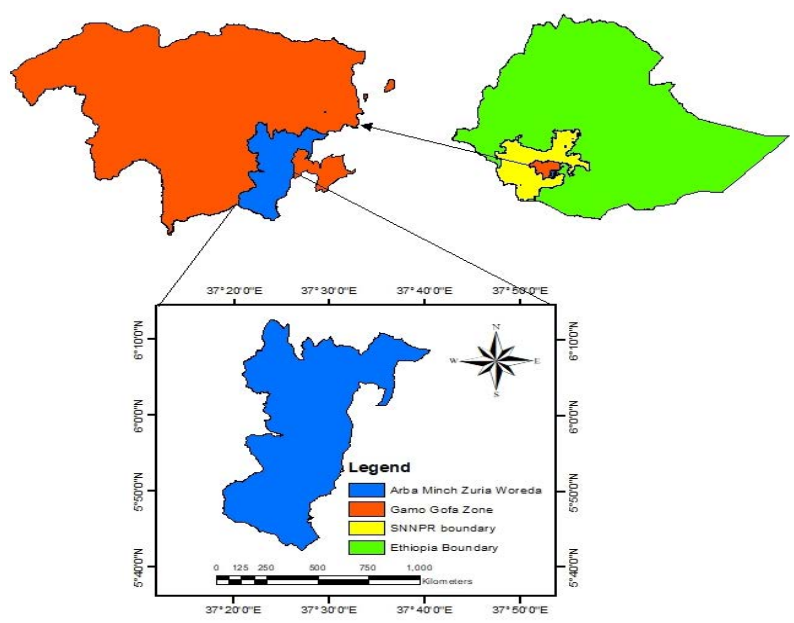

Figure 1. Location map of Arba Minch Zuriya district

Samples of soil, irrigating water, and seven commonly consumed vegetables namely, Swiss chard, lettuce, cabbage, collard green, tomato, green pepper, and carrot were collected from 
irrigational sites in Gamo, Ethiopia. All samples were randomly collected from the farmlands. Soil samples were collected at $15 \mathrm{~cm}$ depth. The collected soil and vegetable samples were put into clean polythene bags and labeled, while water samples were put in previously rinsed and dried bottles; then, all the samples were brought to the Chemistry Laboratory at the Arbaminch University (AMU) for preparation and subsequent atomic sbsorption spectroscopy analysis.

$15 \mathrm{ml}$ of a water sample was taken in a Teflon tube and then $5 \mathrm{ml} \mathrm{HNO}_{3}$ and $1 \mathrm{ml}$. $\mathrm{H}_{2} \mathrm{O}_{2}$ were added to it. The vial was closed tightly and then inserted into a single safety shield carousel installed in a microwave chamber. The mixture was heated at $120^{\circ} \mathrm{C}$ for over $3 \mathrm{hr}$ in a microwave digester. After the process was completed, the clear and colorless solution was filtered using Whatman filter paper No. 42 and diluted with deionized water to raise the volume of the solution to $50 \mathrm{~mL}$ [10]. Finally, the samples were stored in plastic bottles until analysis.

$500 \mathrm{~g}$ of a soil sample was placed in a polythene bag, dried in a microwave oven, and ground into a fine powder which was passed through a $2-\mathrm{mm}$ mesh sieve. $1 \mathrm{~g}$ of a soil sample was diluted in a tri-acid mixture of $(65 \%$ of $\mathrm{HNO}_{3}: 70 \%$ of $\mathrm{HClO}_{4}: 30 \%$ of $\mathrm{H}_{2} \mathrm{O}_{2}$ ) with a $6: 4: 1$ ratio respectively. The solution was heated to $200^{\circ} \mathrm{C}$ over $3 \mathrm{hr}$ until brown fumes ceased to emit from the solution. The solution was filtered through Whatman filter paper No. 42 and then diluted with deionized distilled water to raise the volume of the solution to $50 \mathrm{~mL}$ [10]. The prepared samples were analyzed with flame atomic absorption spectroscopy (model AA 400P, Germany) in order to determine heavy metals concentrations in them.

The vegetable samples were cut into small pieces and then dried using the oven-dry procedure at $105^{\circ} \mathrm{C}$ for $24 \mathrm{hr}$ (Memmert UF 260 plus $230 \mathrm{~V}$ Sunon model) to remove moisture. Dry samples were ground to powder and then bolted through a $1 \mathrm{~mm}$ sift. $0.5 \mathrm{~g}$ of a sample were taken in reference vessels, added with $6 \mathrm{ml}$ of $65 \% \mathrm{HNO}_{3}, 3 \mathrm{ml}$ of $70 \% \mathrm{HClO}_{4}$ and $1 \mathrm{ml}$ of $30 \% \mathrm{H}_{2} \mathrm{O}_{2}$ and then put onto a carousel installed in a microwave unit. The mixture was heated at $80{ }^{\circ} \mathrm{C}$ for over $3 \mathrm{hr}$ in a microwave digester. After the process was completed, the clear and colorless solution was filtered using Whatman filter paper No. 42 and diluted with deionized water to raise the volume of the solution up to $50 \mathrm{~mL}$ [10]. Finally, the samples were stored in plastic bottles till analysis. The samples of vegetables, soils \& waters collected from four sites in Ethiopia are illustrated in Table 1.

Table 1

Samples of vegetables, soils \& waters were taken from four sites in Ethiopia

\begin{tabular}{|c|c|c|c|c|c|}
\hline & \multirow{2}{*}{ Samples } & \multicolumn{4}{|c|}{ Waste water irrigated site } \\
\hline & & KRA & ATSHCA & ALA & CHLA \\
\hline \multirow{7}{*}{$\begin{array}{l}\frac{\infty}{0} \\
\frac{\pi}{0} \\
\stackrel{0}{0} \\
\infty \\
>0\end{array}$} & Swiss chard & $\checkmark$ & $\checkmark$ & $\checkmark$ & $\checkmark$ \\
\hline & Lettuce & $\checkmark$ & $\checkmark$ & $\checkmark$ & $\checkmark$ \\
\hline & Cabbage & $\checkmark$ & $\checkmark$ & $\checkmark$ & $\checkmark$ \\
\hline & $\begin{array}{l}\text { Collard } \\
\text { Greens }\end{array}$ & $\checkmark$ & $\checkmark$ & $\checkmark$ & $\checkmark$ \\
\hline & Tomato & $\checkmark$ & $\checkmark$ & $\checkmark$ & $\checkmark$ \\
\hline & $\begin{array}{l}\text { Green } \\
\text { pepper }\end{array}$ & $\checkmark$ & $\checkmark$ & $\checkmark$ & $\checkmark$ \\
\hline & Carrot & $\checkmark$ & $\checkmark$ & $\checkmark$ & $\checkmark$ \\
\hline \multicolumn{2}{|c|}{ Soil } & $\checkmark$ & $\checkmark$ & $\checkmark$ & $\checkmark$ \\
\hline \multicolumn{2}{|c|}{ Irrigation water } & $\checkmark$ & $\checkmark$ & $\checkmark$ & $\checkmark$ \\
\hline
\end{tabular}

$\mathrm{N}$ o t e : KRA - Kulfo river area, ATSHCA - Arbaminch textile share company area, ALA - Abaya lake area, CHLA - chamo lake area, Right mark $(\checkmark)$ indicates samples collected.

The prepared samples have analyzed for determining heavy metals concentrations in them using atomic absorption spectrometry with flame atomization, microwave oven, and dry oven (FAAS (flame atomic absorption spectroscopy) model AA 400P, Germany). Conventional auxiliary devices were applied. All the solutions were prepared using analytical chemical calibration reagents and deionized water. Graphical calibration standard solutions for all determinations were prepared by sequential dilution of conventional standards per $1,000 \mathrm{ppm}$.

All the procedures used in the present study were selected due to available data on them being successfully applied to determine heavy metals in different matrixes [11]. The instrumental operating conditions for the de- 
termination of heavy metals using FAAS are illustrated in Table 2. To provide high quality of experimental data, each sample was analyzed three times.

Table 2

Instrumental operating condition for determining heavy metals in wastewater, soil, and vegetable samples via FAAS $[12,13]$

\begin{tabular}{|c|c|c|c|c|}
\hline Element & $\begin{array}{c}\text { Wavelength } \\
(\mathrm{nm})\end{array}$ & $\begin{array}{c}\text { Lamp } \\
\text { Current } \\
(\mathrm{mA})\end{array}$ & $\begin{array}{c}\text { Slit Width } \\
(\mathrm{nm})\end{array}$ & $\begin{array}{c}\text { Flame } \\
\text { type }\end{array}$ \\
\hline $\mathrm{Cd}$ & 228.8 & 2.0 & 1.2 & $\begin{array}{c}\text { Air- } \\
\text { acetylene }\end{array}$ \\
\hline $\mathrm{Cr}$ & 357.9 & 6.0 & 0.7 & $\begin{array}{c}\text { Air- } \\
\text { acetylene }\end{array}$ \\
\hline $\mathrm{Pb}$ & 283.3 & 5.0 & 0.7 & $\begin{array}{c}\text { Air- } \\
\text { acetylene }\end{array}$ \\
\hline $\mathrm{Zn}$ & 213.9 & 5.0 & 0.7 & $\begin{array}{c}\text { Air- } \\
\text { acetylene }\end{array}$ \\
\hline $\mathrm{Cu}$ & 324.7 & 4.0 & 0.5 & $\begin{array}{c}\text { Air- } \\
\text { acetylene }\end{array}$ \\
\hline $\mathrm{Ni}$ & 232.0 & 7.0 & 0.6 & $\begin{array}{c}\text { Air- } \\
\text { acetylene }\end{array}$ \\
\hline
\end{tabular}

The procedure was validated according to the protocol guidelines on the International Conference on Harmonization [14]. Analytical grade (Merck, Germany) reagents were used in all the experimental procedures of the research study.

Metals transfer from the contaminated soil to the edible parts of the vegetables was estimated via the transfer factor (TF) formula (1) [15-17].

$$
\mathrm{TF}=\frac{C_{\text {vegetables }}}{C_{\text {soil }}}
$$

where $C_{\text {vegetables }}$ is metals concentration in vegetables $(\mathrm{mg} / \mathrm{kg})$ and $C_{\text {soil }}$ is metals concentration in soils $(\mathrm{mg} / \mathrm{kg})$. The higher is the value of $\mathrm{TF}$, the more available heavy metals are. Hence, high TF values may indicate that heavy metals are poorly retained by soils or they are too efficiently absorbed by vegetables. Low TF values mean that there is a strong bond between heavy metals and colloids in soils.

Metals mobility when they are transferred from soils into plants is a function from physical and chemical properties of soils and vegetable types. This mobility changes when influ- enced by multiple anthropogenic and environmental factors. Differences in the transfer factor calculated for different vegetables may be due to different heavy metals concentrations in soils and differences related to elements consumption by different vegetables.

High accumulation factor (AF) values may indicate a potential health risk for consumers.

Assessment of health risk caused by consuming vegetables irrigated with wastewaters on the examined territories was performed taking into account daily intake rate (DIR). DIR were calculated basing on a questionnaire $(n=400$ for each vegetable) (Table 3$)$.

Table 3

Respondents interviewed for health risk assessment of wastewater irrigated vegetable consumption on the examined territories

\begin{tabular}{|l|c|c|c|}
\hline \multirow{2}{*}{ Respondents } & \multicolumn{2}{|c|}{$\begin{array}{c}\text { Age group } \\
\text { (years old) }\end{array}$} & \multirow{2}{*}{$\begin{array}{c}\text { Total interviewed } \\
\text { persons }\end{array}$} \\
\cline { 2 - 3 } & $<16$ & $>16$ & \\
\hline Male & 95 & 135 & 230 \\
\hline Female & 76 & 94 & 170 \\
\hline Total interviews & \multicolumn{2}{|l|}{} & 400 \\
\hline
\end{tabular}

Average body weight for an adult and a child was taken as $60 \mathrm{~kg}$ and $25 \mathrm{~kg}$ accordingly.

The daily intake rate of metals through consumption of selected vegetables (Swiss chard, lettuce, cabbage, collard green, tomato, green pepper, and carrot) was calculated with the equation (2) [15-19].

$$
\mathrm{DIR}=\frac{C_{\text {metals }} \cdot D_{\text {average vegetable intake }}}{B_{\text {average weight }}}
$$

where $C_{\text {metals }}$ represents average element concentration in vegetable $(\mathrm{mg} / \mathrm{kg})$ and $D_{\text {average vegetable intake }}$ is average daily vegetable consumption or intake (kg/day-person) and $B_{\text {average weight }}$ is average body weight $(\mathrm{kg})$. From our survey, the average daily each vegetable intake for adults and children was considered to be within $0.108-0.293$ and $0.078-0.169 \mathrm{~kg} /$ (person-day) range, respectively, while the average adults and children body weights were considered to be 60 and $25 \mathrm{~kg}$, respectively. All the data are summarized in Table 4. 
Table 4

Average daily intake of each vegetable (kg/day-person)

\begin{tabular}{|l|c|c|c|c|c|c|c|c|}
\hline Vegetables & Swiss Chard & Lettuce & Cabbage & $\begin{array}{c}\text { Collard } \\
\text { Green }\end{array}$ & Tomato & $\begin{array}{c}\text { Green } \\
\text { Pepper }\end{array}$ & Carrot & Total $D_{\text {ave }}$ \\
\hline Adults & 0.227 & 0.163 & 0.246 & 0.293 & 0.231 & 0.108 & 0.187 & 1.455 \\
\hline Children & 0.113 & 0.098 & 0.169 & 0.157 & 0.128 & 0.078 & 0.103 & 0.846 \\
\hline
\end{tabular}

Hazard level for non-carcinogenic contaminants was determined by calculating a Hazard Quotient (HQ) [20]. Hazard quotient or chronic threat assessment in this study was calculated with the equation (3) of $[15,21,22]$. If a hazard quotient value is lower than one, then exposed consumers are assumed to be safe, but if it is equal to or higher than one, it is considered not safe for human health $[22,23]$.

$$
H Q=\frac{D I R}{R f D}
$$

where $D I R$ represents the daily intake rate and $R f D$ represents the reference dose of metals. The $R f D$ values for $\mathrm{Cd}, \mathrm{Pb}, \mathrm{Cr}, \mathrm{Ni}, \mathrm{Zn}$ and $\mathrm{Cu}$ are $0.001,0.004,1.5,0.02,0.3$, and $0.04 \mathrm{mg} / \mathrm{kg}$-day, respectively; these values were taken from integrated risk information system [22, 24, 25].

Hazard index $(H I)$ was developed to evaluate potential health risks for consumers that occurred due to exposure to more than one potential toxic element [25]. It was calculated by summating hazard quotients for each element in each vegetable as per the following formula (4) $[25,20]$.

$$
H I=\sum H Q
$$

We took into account one-directional effects produced on critical organs and systems by the examined heavy metals according to the matrix presented in Table 5.

The data obtained in the research work were statistically processed via calculating average values. Average values for metal concentrations in water, soil, and vegetable samples were compared by using an independent sample $t$-test. Statistics applied software, version 8.1, was used for basic descriptive statistical analysis of the data.
Table 5

Data obtained from ATSDR on effects produced by heavy metals on critical organs and systems

\begin{tabular}{|l|c|c|c|c|c|c|}
\hline $\begin{array}{l}\text { Critical } \\
\text { organs/systems }\end{array}$ & $\mathrm{Zn}$ & $\mathrm{Cd}$ & $\mathrm{Cr}$ & $\mathrm{Cu}$ & $\mathrm{Ni}$ & $\mathrm{Pb}$ \\
\hline $\begin{array}{l}\text { Central nervous } \\
\text { system }\end{array}$ & & & & & & + \\
\hline $\begin{array}{l}\text { Cardiovascular } \\
\text { system }\end{array}$ & & & & & + & \\
\hline Digestive system & & + & & & & + \\
\hline Kidneys & & & + & + & + & \\
\hline Blood & + & + & + & & & \\
\hline Development & & & & & + & + \\
\hline $\begin{array}{l}\text { Reproductive } \\
\text { system }\end{array}$ & & & & & & + \\
\hline $\begin{array}{l}\text { Hormonal } \\
\text { system }\end{array}$ & & & & & & + \\
\hline
\end{tabular}

Results and discussion. Validation results indicated that calibration curves for the various concentration ranges showed good correlation coefficients ranged between 0.9987 and 0.9999, which was higher than the required limit (0.995) for trace element analysis $[26,27]$. This showed that there was a strong correlation between concentration and absorbance indicating that the devices were properly calibrated (Table 6).

The instrumental detection limits (IDL) ranged between 0.0005 and $0.01 \mathrm{mg} / \mathrm{kg}$ and it was below the limit of detection (LOD) indicating good sensitivity of the measuring instrument used for analysis. The limit of detection (LOD) ranged from 0.075 to $0.372 \mathrm{mg} / \mathrm{kg}$. The limit of quantification (LOQ) lied within $0.227-1.127 \mathrm{mg} / \mathrm{kg}$ range and the result shows both the LOD and LOQ values were greater than the IDL; hence, the results obtained via our analysis could be reliable [28].

Recovery results were within $80-120 \%$ range and it was acceptable for metal analysis [29]. The precision of the method was expressed as 
Table 6

Validation Parameters

\begin{tabular}{|c|c|c|c|c|c|c|c|}
\hline Metals & $\begin{array}{c}\text { IDL } \\
(\mathrm{mg} / \mathrm{kg})\end{array}$ & $\begin{array}{c}\mathrm{LOD} \\
(\mathrm{mg} / \mathrm{kg})\end{array}$ & $\begin{array}{c}\text { LOQ } \\
(\mathrm{mg} / \mathrm{kg})\end{array}$ & $\begin{array}{c}\text { Regression } \\
\text { Equation }\end{array}$ & $\begin{array}{c}\text { Correlation Coef- } \\
\text { ficient }\left(R^{2}\right)\end{array}$ & Recovery (\%) & RSD (\%) \\
\hline $\mathrm{Cd}$ & 0.0005 & 0.153 & 0.465 & $y=0.1247 x-0.003$ & 0.9998 & $101.294 \pm 3.398$ & 3.355 \\
\hline $\mathrm{Cr}$ & 0.002 & 0.184 & 0.558 & $y=0.0112 x+0.002$ & 0.9997 & $98.905 \pm 3.578$ & 3.618 \\
\hline $\mathrm{Pd}$ & 0.01 & 0.372 & 1.127 & $y=0.0044 x+0.0009$ & 0.9987 & $99.436 \pm 8.495$ & 8.543 \\
\hline $\mathrm{Zn}$ & 0.0008 & 0.075 & 0.227 & $y=0.1429 x+0.0277$ & 0.9999 & $99.265 \pm 2.095$ & 2.110 \\
\hline $\mathrm{Cu}$ & 0.001 & 0.200 & 0.606 & $y=0.063 x-0.0013$ & 0.9996 & $98.273 \pm 5.608$ & 5.706 \\
\hline $\mathrm{Ni}$ & 0.002 & 0.211 & 0.638 & $y=0.0243 x+0.0019$ & 0.9996 & $98.974 \pm 4.515$ & 4.562 \\
\hline
\end{tabular}

N o t e : ${ }^{\mathrm{a}}$ Source for FAAS; ${ }^{\mathrm{b}} \mathrm{Mean} \pm \mathrm{SD}, n=7, \mathrm{SD}=$ standard deviation, $\mathrm{mg} / \mathrm{kg}$ : milligram per kilogram, RSD: relative standard deviation.

relative standard deviation (RSD) of the three replicate readings. The obtained RSD values ranged from 2.110 to $8.543 \%$, which was under the required control limits $\leq 15 \%$ [30, 31]. These results indicate that the proposed method was precise and accurate.

Average concentrations of heavy metals detected in soil, water, and vegetables samples taken on four examined territories are given in Tables 7-9.

As we can see from the Table 7, average $\mathrm{Cr}, \mathrm{Pb}, \mathrm{Zn}$, and $\mathrm{Ni}$ concentrations in soil samples from all irrigated sites were found to be lower than the recommended upper limits for soils by FAO/WHO \& USEPA [32-35]. The situation is the same with $\mathrm{Cd}$ concentration in soil samples obtained from the ATSHCA and ALA and also $\mathrm{Cu}$ concentration in soil samples obtained from the KRA and ATSHCA.

Concentration of $\mathrm{Cd}$ from KRA and CHLA farms and $\mathrm{Cu}$ concentration from ALA and CHLA irrigated sites were higher than the recommended maximum limit for soil by FAO/WHO \& USEPA [36-40].

The concentrations of $\mathrm{Zn}, \mathrm{Pb}$, and $\mathrm{Cu}$ in the wastewater samples that were detected on all irrigational sites were lower than the recommended maximum level for irrigation water set by USEPA \& FAO/WHO. But at the same time, we detected relatively high concentrations of $\mathrm{Cd}, \mathrm{Cr}$, and $\mathrm{Ni}$ in wastewaters used for irrigation on all the examined territories and these concentrations were higher than maximum recommended levels for these metals. The results obtained show that the wastewater samples are substantially contaminated with these heavy metals. Therefore, attention should be focused on regular monitoring and control of wastewater used for irrigation.

Results obtained via quantifying metals in vegetables are shown in Table 8 . Cd concentration in vegetables grown on the examined territories varied from $0.18 \mathrm{mg} / \mathrm{kg}$ (lettuce, ALA) to $0.45 \mathrm{mg} / \mathrm{kg}$ (Swiss chard, KRA) [41, 42].

Table 7

Average concentration of heavy metals found in soil farmlands and irrigation water

\begin{tabular}{|c|c|c|c|c|c|c|c|c|c|c|}
\hline \multirow{2}{*}{$\begin{array}{c}\text { Heavy } \\
\text { metals }\end{array}$} & \multicolumn{2}{|c|}{ KRA } & \multicolumn{2}{c|}{ ATSHCA } & \multicolumn{2}{c|}{ ALA } & \multicolumn{2}{c|}{ CHLA } & \multicolumn{2}{c|}{$\begin{array}{c}\text { Guidelines for max. } \\
\text { levels in }\end{array}$} \\
\cline { 2 - 13 } & $\begin{array}{c}\text { water } \\
(\mathrm{mg} / \mathrm{L})\end{array}$ & $\begin{array}{c}\text { Soil } \\
(\mathrm{mg} / \mathrm{kg})\end{array}$ & $\begin{array}{c}\text { water } \\
(\mathrm{mg} / \mathrm{L})\end{array}$ & $\begin{array}{c}\text { Soil } \\
(\mathrm{mg} / \mathrm{kg})\end{array}$ & $\begin{array}{c}\text { water } \\
(\mathrm{mg} / \mathrm{L})\end{array}$ & $\begin{array}{c}\text { Soil } \\
(\mathrm{mg} / \mathrm{kg})\end{array}$ & $\begin{array}{c}\text { water } \\
(\mathrm{mg} / \mathrm{L})\end{array}$ & $\begin{array}{c}\text { Soil } \\
(\mathrm{mg} / \mathrm{kg})\end{array}$ & $\begin{array}{c}\text { water } \\
(\mathrm{mg} / \mathrm{L})\end{array}$ & $\begin{array}{c}\text { Soil } \\
(\mathrm{mg} / \mathrm{kg})\end{array}$ \\
\hline $\mathrm{Cd}$ & 0.2605 & 3.9096 & 0.185 & 1.8261 & 0.1634 & 1.7512 & 0.245 & 3.2113 & 0.01 & 3 \\
\hline $\mathrm{Cr}$ & 0.8402 & 19.897 & 0.2567 & 13.0664 & 0.4738 & 16.2893 & 0.6701 & 8.2187 & 0.1 & 50 \\
\hline $\mathrm{Pb}$ & 0.0094 & 13.8313 & 0.0038 & 10.4406 & 0.0024 & 12.5333 & 0.0056 & 11.7341 & $0.015^{\mathrm{c}}$ & 100 \\
\hline $\mathrm{Zn}$ & 0.3488 & 52.2735 & 1.3954 & 42.5626 & 0.1461 & 53.0685 & 0.0770 & 68.5274 & 2 & 300 \\
\hline $\mathrm{Cu}$ & 0.4643 & 48.8125 & 0.6743 & 40.8878 & 1.2759 & 57.1213 & 0.366 & 51.2222 & $2^{\mathrm{d}}$ & $50^{\mathrm{c}}$ \\
\hline $\mathrm{Ni}$ & 0.8767 & 42.1764 & 0.5609 & 31.3822 & 0.3953 & 19.5129 & 0.6811 & 31.3866 & $0.07^{\mathrm{d}}$ & $80^{\mathrm{c}}$ \\
\hline
\end{tabular}

N o t e : ${ }^{a}$ WHO/FAO (2007), ${ }^{b} W H O / F A O ~(2001),{ }^{c} U S E P A ~(2010),{ }^{d} W H O$ (2008), mg/kg: milligram per kilogram, $\mathrm{mg} / \mathrm{L}$ : milligram per litter. 
Table 8

Concentration of heavy metals $(\mathrm{mg} / \mathrm{kg})$ in vegetable samples in four sites of Ethiopia

\begin{tabular}{|c|c|c|c|c|c|c|c|c|c|c|c|c|}
\hline \multirow{2}{*}{ Vegetables } & \multicolumn{6}{|c|}{ Heavy metals } & \multicolumn{6}{|c|}{ Heavy metals } \\
\hline & $\mathrm{Cd}$ & $\mathrm{Cr}$ & $\mathrm{Pb}$ & $\mathrm{Zn}$ & $\mathrm{Cu}$ & $\mathrm{Ni}$ & $\mathrm{Cd}$ & $\mathrm{Cr}$ & $\mathrm{Pb}$ & $\mathrm{Zn}$ & $\mathrm{Cu}$ & $\mathrm{Ni}$ \\
\hline Study area & \multicolumn{6}{|c|}{ KRA } & \multicolumn{6}{|c|}{ ATSHCA } \\
\hline Swiss Chard & $\frac{0,4}{524}$ & $\frac{1,4}{062}$ & $\frac{0,4}{564}$ & $\frac{27,2}{354}$ & $\frac{11,2}{354}$ & $\frac{13,8}{213}$ & $\frac{0,3}{313}$ & $\frac{1,1}{245}$ & $\frac{0,1}{987}$ & $\frac{23,4}{859}$ & $\frac{9,5}{894}$ & $\frac{9,4}{152}$ \\
\hline Lettuce & $\frac{0,2}{537}$ & $\frac{1,8}{213}$ & $\frac{0,3}{125}$ & $\frac{22,4}{562}$ & $\frac{16,4}{235}$ & $\frac{17,7}{014}$ & $\frac{0,1}{897}$ & $\frac{1,4}{526}$ & $\frac{0,1}{595}$ & $\frac{18,5}{642}$ & $\frac{13,8}{976}$ & $\frac{15,8}{631}$ \\
\hline Cabbage & $\frac{0,4}{185}$ & $\frac{2,7}{801}$ & $\frac{0,4}{562}$ & $\frac{14,2}{563}$ & $\frac{16,5}{426}$ & $\begin{array}{l}19,8 \\
916 \\
\end{array}$ & $\frac{0,3}{281}$ & $\frac{2,8}{456}$ & $\frac{0,2}{895}$ & $\frac{10,4}{586}$ & $\frac{14,5}{642}$ & $\frac{18,6}{542}$ \\
\hline Collard Green & $\frac{0,2}{304}$ & $\frac{2,9}{945}$ & $\frac{0,2}{901}$ & $\frac{10,4}{568}$ & $\frac{13,9}{648}$ & $\frac{24,9}{745}$ & $\frac{0,1}{887}$ & $\frac{2,7}{589}$ & $\frac{0,1}{693}$ & $\frac{8,5}{642}$ & $\frac{9,5}{689}$ & $\frac{23,3}{456}$ \\
\hline Tomato & $\frac{0,4}{324}$ & $\frac{1,8}{452}$ & $\frac{0,2}{812}$ & $\frac{13,6}{548}$ & $\frac{24,2}{345}$ & $\frac{26,8}{945}$ & $\frac{0,2}{791}$ & $\frac{1,5}{243}$ & $\frac{0,1}{623}$ & $\frac{10,2}{365}$ & $\frac{19,5}{642}$ & $\frac{24,4}{538}$ \\
\hline Green Pe & $\frac{0,2}{394}$ & $\frac{1,9}{452}$ & $\frac{0,2}{945}$ & $\frac{9,9}{865}$ & $\frac{21,4}{563}$ & $\frac{21,8}{916}$ & $\frac{0,1}{714}$ & $\frac{1,5}{624}$ & $\frac{0,}{91}$ & $\frac{5,4}{568}$ & $\frac{16,5}{894}$ & $\frac{20,6}{542}$ \\
\hline Carrot & $\frac{0,3}{515}$ & $\frac{2,0}{145}$ & $\frac{0,3}{912}$ & $\frac{12,4}{568}$ & $\frac{25,2}{345}$ & $\frac{25,7}{865}$ & $\frac{0,2}{988}$ & $\frac{1,7}{451}$ & $\frac{0,3}{056}$ & $\frac{9,4}{758}$ & $\frac{20,5}{642}$ & $\frac{21,5}{917}$ \\
\hline FAO/WHO & 0,200 & 2,3 & 0,3 & 99,4 & 73,3 & 67 & 0,2 & 2,3 & 0,3 & 99,4 & 73,3 & 67 \\
\hline Study area & \multicolumn{6}{|c|}{ ALA } & \multicolumn{6}{|c|}{ CHLA } \\
\hline Swiss Chard & $\underline{0,3}$ & $\frac{1,2}{345}$ & $\frac{0,2}{956}$ & $\frac{28,3}{793}$ & $\frac{11,5}{564}$ & $\frac{5,3}{914}$ & $\frac{0,4}{194}$ & $\frac{1,0}{292}$ & $\frac{0,3}{477}$ & $\frac{31,4}{526}$ & $\frac{9,9}{524}$ & $\frac{11,3}{121}$ \\
\hline Lettuce & $\frac{0,1}{797}$ & $\frac{1,5}{462}$ & $\frac{0,1}{895}$ & $\frac{24,3}{427}$ & $\frac{18,5}{462}$ & $\frac{9,8}{756}$ & $\frac{0,2}{165}$ & $\frac{1,6}{271}$ & $\frac{0,3}{9}$ & $\frac{27,4}{589}$ & $\frac{17,4}{371}$ & $\frac{16,8}{123}$ \\
\hline Cabbage & $\frac{0,2}{973}$ & $\frac{2,0}{461}$ & $\frac{0,3}{125}$ & $\frac{16,4}{24}$ & $\frac{20,6}{542}$ & $\frac{11,9}{517}$ & $\frac{0,3}{685}$ & $\frac{2,1}{686}$ & $\frac{0,4}{218}$ & $\frac{21,5}{643}$ & $\frac{18,4}{682}$ & $\frac{17,9}{453}$ \\
\hline Collard Green & $\frac{0,1}{91}$ & $\frac{2,2}{451}$ & $\frac{0,1}{885}$ & $\frac{12,2}{014}$ & $\frac{16,2}{457}$ & $\frac{17,8}{501}$ & $\frac{0,2}{155}$ & $\frac{2,6}{527}$ & $\frac{0,2}{189}$ & $\frac{16,8}{956}$ & $\frac{14,3}{566}$ & $\frac{22,7}{254}$ \\
\hline Tomato & $\frac{0,3}{152}$ & $\frac{1,4}{452}$ & $\frac{0,1}{812}$ & $\frac{15,0}{882}$ & $\frac{32,4}{568}$ & $\frac{15,3}{968}$ & $\frac{0,4}{57}$ & $\frac{1,6}{977}$ & $\frac{0,2}{101}$ & $\frac{19,5}{641}$ & $\frac{26,3}{741}$ & $\frac{25,8}{745}$ \\
\hline Green Pepper & $\frac{0,1}{885}$ & $\frac{1,7}{854}$ & $\frac{0,2}{282}$ & $\frac{10,6}{628}$ & $\frac{29,5}{463}$ & $\frac{16,7}{969}$ & $\frac{0,2}{51}$ & $\frac{1,6}{362}$ & $\frac{0,2}{586}$ & $\frac{14,5}{623}$ & $\frac{23,1}{016}$ & $\frac{19,9}{453}$ \\
\hline Carrot & $\frac{0,2}{92}$ & $\frac{1,6}{123}$ & $\frac{0,3}{156}$ & $\frac{14,5}{447}$ & $\frac{31,4}{568}$ & $\frac{15,8}{259}$ & $\frac{0,3}{421}$ & $\frac{1,9}{557}$ & $\frac{0,3}{524}$ & $\frac{17,5}{659}$ & $\frac{26,0}{377}$ & $\frac{23,6}{895}$ \\
\hline FAO/WHO (2001) & 0,2 & 2,3 & 0,3 & 99,4 & 73,3 & 67 & 0,2 & 2,3 & 0,3 & 99,4 & 73,3 & 67 \\
\hline
\end{tabular}

Average concentration of heavy metals $(\mathrm{mg} / \mathrm{kg})$ found in vegetables from all farms

\begin{tabular}{|c|c|c|c|c|c|c|c|c|}
\hline $\begin{array}{c}\text { Heavy } \\
\text { Metals }\end{array}$ & $\begin{array}{c}\text { Swiss } \\
\text { Chard }\end{array}$ & Lettuce & Cabbage & $\begin{array}{c}\text { Collard } \\
\text { Green }\end{array}$ & Tomato & $\begin{array}{c}\text { Green } \\
\text { Pepper }\end{array}$ & Carrot & $\begin{array}{c}\text { Guideline Value } \\
(\mathrm{mg} / \mathrm{kg})^{\mathrm{a}}\end{array}$ \\
\hline $\mathrm{Cd}$ & 0.38 & 0.21 & 0.35 & 0.21 & 0.36 & 0.20 & 0.32 & 0.2 \\
\hline $\mathrm{Cr}$ & 1.20 & 1.61 & 2.46 & 2.66 & 1.63 & 1.73 & 1.83 & 2.3 \\
\hline $\mathrm{Pb}$ & 0.32 & 0.24 & 0.37 & 0.22 & 0.21 & 0.24 & 0.34 & 0.3 \\
\hline $\mathrm{Zn}$ & 27.64 & 23.21 & 15.67 & 12.03 & 14.64 & 10.17 & 13.51 & 99.4 \\
\hline $\mathrm{Cu}$ & 10.58 & 16.58 & 17.56 & 13.53 & 25.66 & 22.67 & 25.82 & 73.3 \\
\hline $\mathrm{Ni}$ & 9.99 & 15.06 & 17.11 & 22.22 & 23.15 & 19.82 & 21.72 & 67 \\
\hline
\end{tabular}

$\mathrm{N}$ o t e : ${ }^{a}$ FAO/WHO-codex alimentarius commission (2001).

Cd concentrations were not significantly high in Lettuce, Collard Green, and Green Pepper and didn't differ greatly on the examined territories [43-45]. However, Cd concentrations detected in Swiss chard, Cabbage, to- mato, and carrot mostly from KRA and CHLA sites were higher than the permissibility level set by FAO/WHO. Among the sampling sites, the samples from the KRA site contained the highest $\mathrm{Cd}$ concentration which might be at- 
tributed to the sewage sludge discharge from the cement processing, metal manufacturing, stone crushing machine, and industrial waste from textile which dispose its wastes directly into the river [46, 47].

The concentration of $\mathrm{Cr}$ was observed to be the highest for collard green samples $(2.99 \mathrm{mg} / \mathrm{kg})$ from KRA. The concentrations of $\mathrm{Cr}$ detected in cabbage and collard green of the vegetables analyzed from KRA and ATSHCA sites and collard green from CHLA site were higher than the limit levels in food by FAO/WHO guidelines. Among the investigated vegetables, cabbage and collard green were found to be more Cr-loaded than other vegetables. High concentrations of this heavy metal were detected in vegetables from KRA, ATSHCA, and CHLA sites which might be due to sewage sludge discharged to the environment from metal production, cement production, textile production, and stone crashing sites or due to pollution from agronomic practices [48].

The $\mathrm{Pb}$ content was the highest in Swiss chard $(0.46 \mathrm{mg} / \mathrm{kg})$ and cabbage $(0.46 \mathrm{mg} / \mathrm{kg})$ collected on KRA farms and the lowest in lettuce $(0.16 \mathrm{mg} / \mathrm{kg})$ collected on ATSHCA farms. The $\mathrm{Pb}$ content in all of the vegetables from all farms, except Swiss chard and cabbage from KRA farms were found to be within the safe limit stated by FAO/WHO [49].

The highest concentrations of $\mathrm{Cu}$ were in tomato $(32.46 \mathrm{mg} / \mathrm{kg})$ follow by carrot $(31.46 \mathrm{mg} / \mathrm{kg})$ and green pepper $(29.55 \mathrm{mg} / \mathrm{kg})$ from ALA while the lowest $\mathrm{Cu}$ concentration was detected for collard green $(9.57 \mathrm{mg} / \mathrm{kg})$ from ATSHCA farms. Similarly, the highest levels of $\mathrm{Ni}$ were in tomato $(26.89 \mathrm{mg} / \mathrm{kg})$ from KRA while the lowest one was detected for Swiss chard $(5.39 \mathrm{mg} / \mathrm{kg}$ ) from ALA farms. The $\mathrm{Cu}$ and $\mathrm{Ni}$ content in all of the vegetable samples from all farms were found to be within the safe limit stated by FAO/WHO which is $73.3 \mathrm{mg} / \mathrm{kg}$ and $67 \mathrm{mg} / \mathrm{kg}$ respectively [50].

The results shown in Table 7 contain average concentration of zinc in all vegetable samples. CHLA had the highest concentration of $31.45 \mathrm{mg} / \mathrm{kg}$ in Swiss chard followed by $28.38 \mathrm{mg} / \mathrm{kg}$ in Swiss chard from the ALA site while the lowest concentration was obtained from the ATSHCA site with $5.46 \mathrm{mg} / \mathrm{kg}$ in green pepper [51]. This indicates that zinc was contained in all samples in concentrations that were within the stipulated limit stated by $\mathrm{FAO} / \mathrm{WHO}$ which is $99.40 \mathrm{mg} / \mathrm{kg}$.

All the obtained data allowed estimating transfer factor (TF) for various heavy metals transfer from soils into vegetables. The results are given in Table 10.

Swiss chard has the highest transfer factor values for $\mathrm{Zn}(0.52)$ followed by $\mathrm{Ni}$ (0.32). Lettuce has the highest transfer factor values for $\mathrm{Ni}(0.49)$ followed by $\mathrm{Zn}(0.43)$ [52]. As for the other vegetables, the highest $\mathrm{TF}$ values were detected for $\mathrm{Ni}$ (from 0.56 to 0.76 ) and $\mathrm{Cu}$ (from 0.27 to 0.52 ). Overall, $\mathrm{TF}$ values for heavy metals in the examined vegetable samples were in the following order:

$$
\mathrm{Ni}>\mathrm{Cu}>\mathrm{Zn}>\mathrm{Cr}>\mathrm{Cd}>\mathrm{Pb} .
$$

The highest TF values were found to be 0.76 and 0.52 for $\mathrm{Ni}$ and $\mathrm{Zn}$ respectively. These might be due to the higher mobility of these heavy metals together with natural occurrence in soil and their lower retention in soil than other toxic elements [53,54].

Table 10

Transfer Factor (TF) of heavy metals from soil to vegetables

\begin{tabular}{|c|c|c|c|c|c|c|c|c|}
\hline $\begin{array}{c}\text { Heavy } \\
\text { metals }\end{array}$ & $\begin{array}{c}\text { Swiss } \\
\text { Chard }\end{array}$ & Lettuce & Cabbage & $\begin{array}{c}\text { Collard } \\
\text { Green }\end{array}$ & Tomato & $\begin{array}{c}\text { Green } \\
\text { Pepper }\end{array}$ & Carrot & Average TF \\
\hline $\mathrm{Cd}$ & 0.12 & 0.08 & 0.12 & 0.08 & 0.12 & 0.08 & 0.13 & 0.104 \\
\hline $\mathrm{Cr}$ & 0.09 & 0.12 & 0.19 & 0.21 & 0.13 & 0.13 & 0.14 & 0.14 \\
\hline $\mathrm{Pb}$ & 0.03 & 0.02 & 0.03 & 0.02 & 0.02 & 0.02 & 0.03 & 0.024 \\
\hline $\mathrm{Zn}$ & 0.52 & 0.43 & 0.29 & 0.22 & 0.27 & 0.18 & 0.25 & 0.31 \\
\hline $\mathrm{Cu}$ & 0.22 & 0.34 & 0.35 & 0.27 & 0.51 & 0.45 & 0.52 & 0.38 \\
\hline $\mathrm{Ni}$ & 0.32 & 0.49 & 0.56 & 0.74 & 0.76 & 0.67 & 0.72 & 0.61 \\
\hline
\end{tabular}


We combined data on metals concentrations in vegetables with data on daily intake rate for each product; it allowed us to calculate daily intake of heavy metals into a body [55] (Table 11).

Daily intakes gave grounds for determining hazard quotients (Table 12). As we can see form these data, daily intakes of $\mathrm{Cd}$, $\mathrm{Cu}$, and $\mathrm{Ni}$ were higher than reference doses (RfD) recommended by USEPA and FAO/WHO both children and adults [24, 56]. The values of $H Q$ were less than 1.0 for $\mathrm{Cr}, \mathrm{Pb}$, and $\mathrm{Zn}$ in all tested vegetables and $\mathrm{Cd}$ in lettuce and green pepper for both adults and children, thus indicating a risk was insignificant.
The highest hazard (HQ) quotients were revealed for Swiss chard, tomato, and cabbage for both adults and children. Therefore, consumption of Swiss chard, tomato, and cabbage grown on the examined territories can cause high health risks.

Hazard quotients were used as a basis for estimating hazard indexes that showed probability of functional disorders in specific organs and systems due to toxic elements prodding similar effects on them [57]. In the present study it was revealed (Table 13) that the highest health risks for people who daily consumed vegetables grown on the examined irrigated sites were related to functional disorders in the kidneys, cardiovascular system and overall development [58].

Table 11

Average daily intake of Heavy metals through consumption of vegetables ( $\mathrm{mg} / \mathrm{kg}$-day)

\begin{tabular}{|c|c|c|c|c|c|c|c|c|c|c|c|}
\hline $\begin{array}{l}\text { Heavy } \\
\text { metals }\end{array}$ & Individual & $\begin{array}{l}\text { Swiss } \\
\text { Chard }\end{array}$ & Lettuce & Cabbage & $\begin{array}{c}\text { Collard } \\
\text { Green }\end{array}$ & Tomato & $\begin{array}{l}\text { Green } \\
\text { Pepper }\end{array}$ & Carrot & $\begin{array}{c}\text { Average } \\
\text { DIR }\end{array}$ & $\begin{array}{l}\text { Sum } \\
\text { DIR }\end{array}$ & $\mathrm{RfD}$ \\
\hline \multirow{2}{*}{$\mathrm{Cd}$} & Adults & 0.0022 & 0012 & 0.0020 & 0.0012 & 0021 & 0.0012 & 001 & 0.0017 & 0.0072 & \multirow{2}{*}{0.001} \\
\hline & Children & 0.0035 & 0.0020 & 0.0033 & 0.0020 & 0.00 & 0.0019 & 00 & $\overline{0.002}$ & 0.01 & \\
\hline \multirow{2}{*}{$\mathrm{Cr}$} & Adults & 0.0070 & 0.0093 & D143 & 0.0154 & 0095 & 0100 & 6 & 0.01 & 0.04 & \multirow{2}{*}{1.5} \\
\hline & Children & 0.0112 & 0.015 & 0.0229 & 0.0248 & 0.0152 & 0.0161 & .0171 & 0.0175 & 0.0662 & \\
\hline \multirow{2}{*}{$\mathrm{Pl}$} & dults & 0.0019 & 0.0014 & 0022 & 0.0013 & 0.0012 & 0.0014 & 002 & 0.0016 & 0.0068 & \multirow{2}{*}{0.00} \\
\hline & Children & 0.003 & 0.0022 & 0.0035 & 0.0021 & 0.002 & 0.0022 & .0032 & 0.0026 & 0.0096 & \\
\hline & dults & 1603 & 346 & 0909 & 0.0698 & 0 & 0.0590 & 34 & 0.0968 & 0.4072 & \multirow{2}{*}{0.3} \\
\hline & Children & 0.2576 & 0.2163 & 0.1460 & 0.1121 & 0.1364 & 0.0948 & 0.1259 & 0.1556 & 0.5596 & \\
\hline \multirow{2}{*}{$\mathrm{Cu}$} & ults & 0.0614 & 0.0962 & 0.1019 & 0.0785 & 0.1488 & 0.1315 & 0.1498 & 0.1097 & 0.4432 & \multirow{2}{*}{0.04} \\
\hline & Children & 0.0986 & 0.1545 & 0.1637 & 0.1261 & 0.2391 & 0.2113 & 0.2406 & 0.1763 & 0.625 & \\
\hline & & 0.0579 & 0.0874 & 0.0992 & 0.1289 & 0.1343 & 0.1150 & 0.1260 & 0.1069 & 0.4499 & \multirow{2}{*}{0.02} \\
\hline & Children & 0.0931 & 0.1404 & 0.1595 & 0.2071 & 0.2158 & 0.1847 & 0.2024 & 0.1719 & 0.6293 & \\
\hline
\end{tabular}

Table 12

Hazard Quotient of Heavy metals via intake of vegetables from wastewater irrigated farms

\begin{tabular}{|c|c|c|c|c|c|c|c|c|}
\hline $\begin{array}{c}\text { Heavy } \\
\text { metals }\end{array}$ & Individual & Swiss Chard & Lettuce & Cabbage & $\begin{array}{c}\text { Collard } \\
\text { Green }\end{array}$ & Tomato & $\begin{array}{c}\text { Green } \\
\text { Pepper }\end{array}$ & Carrot \\
\hline \multirow{2}{*}{$\mathrm{Cd}$} & Adults & 2.204 & 1.218 & 2.03 & 1.218 & 2.088 & 1.16 & 1.856 \\
\cline { 2 - 9 } & Children & 3.542 & 1.957 & 3.262 & 1.957 & 3.355 & 1.864 & 2.982 \\
\hline \multirow{2}{*}{$\mathrm{Cr}$} & Adults & 0.005 & 0.006 & 0.010 & 0.010 & 0.006 & 0.007 & 0.007 \\
\cline { 2 - 8 } & Children & 0.008 & 0.010 & 0.015 & 0.017 & 0.010 & 0.011 & 0.011 \\
\hline \multirow{2}{*}{$\mathrm{Pb}$} & Adults & 0.464 & 0.348 & 0.537 & 0.319 & 0.305 & 0.348 & 0.493 \\
\cline { 2 - 9 } & Children & 0.746 & 0.559 & 0.862 & 0.513 & 0.489 & 0.559 & 0.792 \\
\hline \multirow{2}{*}{$\mathrm{Zn}$} & Adults & 0.534 & 0.449 & 0.303 & 0.233 & 0.283 & 0.197 & 0.261 \\
\cline { 2 - 9 } & Children & 0.859 & 0.721 & 0.487 & 0.374 & 0.455 & 0.316 & 0.420 \\
\hline \multirow{2}{*}{$\mathrm{Cu}$} & Adults & 1.534 & 2.404 & 2.546 & 1.962 & 3.721 & 3.287 & 3.744 \\
\cline { 2 - 8 } & Children & 2.465 & 3.863 & 4.092 & 3.153 & 5.979 & 5.282 & 6.016 \\
\hline \multirow{2}{*}{$\mathrm{Ni}$} & Adults & 2.897 & 4.367 & 4.962 & 6.444 & 6.714 & 5.748 & 6.299 \\
\cline { 2 - 8 } & Children & 4.655 & 7.018 & 7.973 & 10.355 & 10.788 & 9.236 & 10.122 \\
\hline
\end{tabular}


Table 13

Hazard Index of heavy metals that affect the same target organs and systems

\begin{tabular}{|c|c|c|c|c|c|c|c|c|c|}
\hline \multirow{2}{*}{$\begin{array}{c}\text { Critical } \\
\text { organs/systems }\end{array}$} & \multirow{2}{*}{ Group } & \multirow{2}{*}{$\mathrm{HI}_{\text {макс }}$} & \multirow{2}{*}{$\mathrm{HI}_{\text {средн }}$} & \multicolumn{6}{|c|}{ Contribution made by specific metals into risks, $\%$} \\
\hline & & & & $\mathrm{Zn}$ & $\mathrm{Cd}$ & $\mathrm{Cr}$ & $\mathrm{Cu}$ & $\mathrm{Ni}$ & $\mathrm{Pb}$ \\
\hline \multirow{2}{*}{ Central nervous system } & adults & 1.7 & 0.24 & & & & & & 100 \\
\hline & children & 2.4 & 0.34 & & & & & & 100 \\
\hline \multirow{2}{*}{ Cardiovascular system } & adults & 22.5 & 3.21 & & & & & 100 & \\
\hline & children & 31.5 & 4.50 & & & & & 100 & \\
\hline \multirow{2}{*}{ Digestive system } & adults & 8.9 & 1.27 & & 80.90 & & & & 9.10 \\
\hline & children & 12.5 & 1.78 & & 80.90 & & & & 9.10 \\
\hline \multirow{2}{*}{ Kidneys } & adults & 33.61 & 4.79 & & & 0.09 & 32.97 & 66.94 & \\
\hline & children & 47.14 & 6.74 & & & 0.08 & 33.16 & 66.76 & \\
\hline \multirow{2}{*}{ Blood: } & adults & 14.11 & 1.23 & 16.01 & 83.63 & 0.36 & & & \\
\hline & children & 22.81 & 1.71 & 15.91 & 83.73 & 0.36 & & & \\
\hline \multirow{2}{*}{ Development } & adults & 40.29 & 3.46 & & & & & 92.93 & 7.07 \\
\hline & children & 64.70 & 4.84 & & & & & 92.97 & 7.03 \\
\hline \multirow{2}{*}{ Reproductive system } & adults & 1.7 & 0.24 & & & & & & 100 \\
\hline & children & 2.4 & 0.34 & & & & & & 100 \\
\hline
\end{tabular}

Conclusion. Results obtained in the present study allow concluding that consumption of vegetables irrigated with wastewaters results in unacceptable health risks, both for adults and children. The authors suggest regular monitoring over heavy metals contents in soils, irrigation water, and food products as it will allow avoiding substantial heavy metals accumulation in food chains and therefore health risks will be reduced.

Results obtained in the present study can become a stimulus for ecologists, managers, and public healthcare experts in their activities aimed at informing people about hazards related to consuming vegetables that are grown on contaminated territories; it can lead to reduction in health risks.

Acknowledgements. The authors would like to thank the physics department of Addis Ababa University $(A A U)$ and the chemistry department of Arba Minch University (AMU) for laboratory facilities.

Funding. In addition the authors would like to thank the AAU and AMU for the research grant support.

Conflict of interests. The authors declare no conflict interest concerning this publication.

\section{References}

1. Agency for Research on Cancer (IARC). Fruit and vegetables. Lyon, International Agency for Research on Cancer Publ., 2003, 24 p.

2. Delibacak S., Elmaci O.L., Secer M., Bodur A. Trace element and heavy metal concentrations in fruits \&vegetables of the Gediz River region. International Journal of Water, 2002, vol. 2, no. 2-3, pp. 196-211.

3. Fasuyi O.A. Nutritional potentials of some tropical vegetable leaf meals: Chemical characterization and functional properties. African Journal of Biotechnology, 2006, vol. 5, no. 1, pp. 49-53.

4. Orech F.O., Akenga T., Ochora J., Friis H., Aagaard H. Potential toxicity of some traditional leafy vegetables consumed in Nyang'oma Division, Western Kenya. African Journal for Food Agriculture and Nutritional Development, 2005, vol. 5, no. 1, pp. 1-14.

5. Okeno J.A., Chebet D.K., Mathenge P.W. Status of indigenous vegetables in Kenya. Acta Hort, 2003, vol. 621, no. 9, pp. 95-100. DOI: 10.17660/ActaHortic.2003.621.10

6. Smith F.I., Eyzaguirre P. African leafy vegetables: Their role in the world health organization's global fruit and vegetables initiatives. African Journal for Food Agriculture Nutritional Development, 2007, no. 7, pp. 1-9.

7. Qu C., Ma Z., Yang J., Liu Y., Bi J., Huang L. Human Exposure Pathways of Heavy Metal in a Lead-Zinc Mining Area. Heavy Metal Contamination of Water and Soil: Analysis, assessment, and remediation strategies, 2014, pp. 129-156. 
8. Tchounwou P.B., Yedjou C.G., Patlolla A.K., Sutton D.J. Heavy metal toxicity and the environment. Experiential Supplementum, 2012, no. 101, pp. 133-164. DOI: 10.1007/978-3-7643-8340-4_6

9. Highlights of the Exposure factors Handbook (Final Report). National Center for Environmental Assessment Office of Research and Development U.S. Environmental Protection Agency, 2011, 72 p.

10. Method 3005A. Acid digestion of water for total recoverable or dissolved metals for analysis by FLAA or ICP-Spectroscopy. Washington, DC: Environmental Protection Agency (EPA) Publ., $1998,5 \mathrm{p}$.

11. Helaluddin A.B.M., Reem S.K., Mohamed A., Syed A.A. Main Analytical Techniques Used for Elemental Analysis in Various Matrices. Tropical Journal of Pharmaceutical Research, 2016, vol. 15 , no. 2, pp. 427-434. DOI: 10.4314/tjpr.v15i2.29

12. Dagne B.B. Levels of Some Toxic Heavy Metals in Selected Vegetables, Soil and wastewater Around Eastern Industry Zone, Central Ethiopia. MSc Graduate project. Haramaya, Haramaya University Publ., 2017, 6 p.

13. Deribachew B., Made M., Nigussie-Dechassa R., Abi M.T. Selected heavy metals in some vegetables produced through wastewater irrigation and their toxicological implications in eastern Ethiopia. African Journal of Food, Agriculture, Nutrition, and Development, 2015, vol. 15, no. 70, pp. 10013.

14. International Conference on Harmonization (ICH). Validation of Analytical Procedures: Text and Methodology. ICH, 1994. Available at: http://www.ich.org/fileadmin/Public/Web_Site/ICH_Products/Guidelines/Quality/Q2_R1/Step4/Q2_R1_Guideline (19.02.2021).

15. Chary N.S., Kamala C.T., Raj D.S. Assessing the risk of heavy metals from consuming food grown on sewage irrigated soils and food chain transfer. Ecotoxicology Environmental Safety, 2008, vol. 69, no. 3, pp. 513-524. DOI: 10.1016/j.ecoenv.2007.04.013

16. Cui Y., Zhu Y., Zhai R., Huang Y., Qui Y., Liang L. Transfer of metals from near a smelter in Nanning, China. Environmental International Journal, 2004, vol. 30, no. 6, pp. 785-791. DOI: 10.1016/j.envint.2004.01.003

17. Khan K., Lu Y., Khan H., Ishtiaq M., Khan S., Waqas M., Wei L., Wang T. Heavy metals in agricultural soils and crops and their health risks in Swat District, northern Pakistan. Food and Chemical Toxicology, no. 58, pp. 449-458. DOI: 10.1016/j.fct.2013.05.014

18. Orisakwe O.E., Nduka J.K., Amadi C.N., Dike D.O., Bede O. Heavy metal health risk assessment for population via consumption of food crops and fruits in Owerri, South Eastern, Nigeria. Chemistry Central Journal, 2012, vol. 1, no. 6 (1), pp. 77. DOI: 10.1186/1752-153X-6-77

19. Aschale M., Sileshi Y., Kelly-Quinn M. Health risk assessment of potentially toxic elements via consumption of vegetables irrigated with polluted river water in Addis Ababa, Ethiopia. Environmental Systems Research, 2019, vol. 8, no. 1, pp. 29. DOI: 10.1186/s40068-019-0157-x

20. U.S. Environmental Protection Agency Risk Characterization Handbook, EPA 100-B-00-002. Science Policy Council U.S. Environmental Protection Agency Washington, DC 20460 Publ., 2000, 189 p.

21. Khan S., Lin A., Zhang S., Hu Q.H., Zhu Y.G. Accumulation of polycyclic aromatic hydrocarbons and heavy metals in lettuce grown in the soils contaminated with long-term wastewater irrigation. Journal of Hazardous Materials, 2008, vol. 152, no. 2, pp. 506-515. DOI: 10.1016/j.jhazmat.2007.07.014

22. EPA Region 9 (Pacific Southwest). USEPA (U.S. Environmental Protection Agency), 2002. Available at: http://www.epa.Gov/region09/waste/sfund/prg (19.02.2021).

23. Reference dose (RfD): Description and use in health risk assessments, Background Document 1A, Integrated risk information system (IRIS). USEPA (U.S. Environmental Protection Agency), 2013. Available at: http://www.epa.gov/iris/rfd.tm (19.02.2021).

24. Provisional Peer-Reviewed Toxicity Values (PPRTV) for Iron and Compounds (CASRN 7439-89-6). Superfund Health Risk Technical Support Center National Center for Environmental Assessment Office of Research and Development U.S. Environmental Protection Agency Cincinnati, OH 45268, 2008, $44 \mathrm{p}$.

25. USEPA (U.S. Environmental Protection Agency Integrated Risk Information System (IRIS) on Arsenic. Arsenic, inorganic (CASRN7440-38-2). USEPA (U.S. Environmental Protection Agency), 1998. Available at: http://www.epa.gov /iris/subst/0278.htm (19.02.2021). 
26. Solutions to Analytical Chemistry Problems with Clean Water Act Methods. Washington, DC, USEPA, 2007, 62 p.

27. Christian G.D., Analytical Chemistry, $6^{\text {th }}$ edition. New York, John Wiley and Sons Publ., 2003, 128 p.

28. Temminghoff E.J., Houba V.J. Plant Analysis Procedures Second Edition. Netherlands, Kluwer Academic Publishers Publ., 2004, 180 p.

29. National Functional Guidelines for Superfund Organic Methods Data Review. Washington, DC, USEPA Publ., 2008, 250 p.

30. Csuros M., Csuros C. Environmental sampling and analysis of metals. USA, CRC Press Publ., 2002, 404 p.

31. Parsons M.L., Forster A.L. Trace Element Determination by Atomic Spectroscopic Methods State of the Art. Applied Spectroscopy, 1983, vol. 37, pp. 411-418. DOI: 10.1366/0003702834634857

32. Tamiru A.A., Hameed S., Amare H. Metal Concentration in Vegetables Grown in the Hydrothermally Affected Area in Ethiopia. Journal of Geography \& Geology, 2011, vol. 3, no. 1, pp. 8. DOI: 10.5539/jgg.v3n1p86

33. Alemayehu T. Heavy metal concentration in the urban environment of Addis Ababa Ethiopia. Journal of Soil and sediment contamination, 2006, vol. 15, no. 6, pp. 591-602. DOI: $10.1080 / 15320380600959081$

34. Report of the 33rd session of the codex committee on food additives and contaminants. The Netherlands, Joint FAO/WHO food standards programme. Codex Alimentarius commission, 2001, 300 p.

35. Risk-based concentration table. Washington, DC, USEPA (United State Environmental Protection Agency) Publ., 2010, 11 p.

36. Mensah E., Allen H.E., Shoji R., Odai S.N., Kyei-Baffour N., Ofori E., Mezler D. Cadmium $(\mathrm{Cd})$ and lead $(\mathrm{Pb})$ concentrations effect on yields of some vegetables due to uptake from irrigation water in Ghana. International Journal of Agricultural Research, 2008, vol. 3, no. 4, pp. 243-251. DOI: 10.3923/ijar.2008.243.251

37. Othman O.C. Heavy metals in green vegetables and soils from vegetable gardens in Dar es Salaam, Tanzania. Tanzania Journal of Science, 2001, vol. 27, no. 1, pp. 37-48. DOI: 10.4314/tjs.v27i1.18334

38. Nazif W., Perveen S., Shah S.A. Evaluation of irrigation water for heavy metals of Akbarpura area. Journal of Agricultural and Biological Science, 2006, vol. 1, pp. 51-54.

39. Report of the thirty-ninth session of the codex committee on food hygiene. New Delhi, Joint FAO/WHO food standards programme Codex Alimentarius commission, 2008, $104 \mathrm{p}$.

40. Guidelines for Drinking Water Quality, $3^{\text {rd }}$ edition. World health organization, 2008, $668 \mathrm{p}$.

41. Kim M.H., Kim J.S., Sho Y.S., Chung S.Y., Lee J.O. Contents of toxic metals in fruits available on Korean markets. Korean Journal of Food Science and Technology, 2004, vol. 36, no. 4, pp. 523-526.

42. Jolaoso A.O., Njoku K.L., Akinola M.O., Adeola A.A. Heavy metal analyses and nutritional composition of raw and smoked fishes from Ologe and Lagos Lagoon, Lagos, Nigeria. Journal of Applied Sciences and Environmental Management, 2016, vol. 20, no. 2, pp. 277-285. DOI: 10.4314/jasem.v20i2.7

43. Divrikli U., Horzum N., Soylak M., Elci L. Trace Heavy Metal Contents of Some Spices and Herbal Plants from Western Anatolia, Turkey. International Journal of Food Science Technology, 2006, vol. 41, no. 6, pp. 712-716. DOI: 10.1111/j.1365-2621.2005.01140.x

44. Doherty V.F., Sogbanmu T.O., Kanife U.C., Wright C. Heavy Metals in Vegetables collected from elected Farm and Market sites in Lagos, Nigeria. Global Advanced Research Journal of Environmental Science and Toxicology's, 2012, vol. 1, no. 6, pp. 137-142.

45. Jabeen S., Shah M.T., Khan S., Qasim M. Determination of Major and Trace Elements in Ten Important Folk Therapeutic Plants of Haripur Basin. Journal of medicinal plant research, 2010, vol. 4, no. 7, pp. 559-566.

46. Khan M.A., Ahmad I., Inayatur R. Effect of environmental pollution on heavy metals content of Withania somnifera. Journal of the Chinese Chemical Society, 2007, vol. 54, pp. 339-343. DOI: $10.1002 /$ jccs. 200700049

47. Davies B.E. Cadmium in Heavy Metals in Soil. Glasgow, Blackie Publ., 1990, 100 p.

48. Girmaye B.R. Heavy metal and microbial contaminants of some vegetables irrigated with wastewater in selected farms around Adama town, Ethiopia. MSc. Graduate project. Haramaya, Haramaya University Publ., 2012, 12 p. 
49. Kalagbor I., Diri E. Evaluation of Heavy Metals in Orange, Pineapple, Avocado Pear, and Pawpaw from a Farm in Kaani, Bori, Rivers State Nigeria. International Research Journal of Public and Environmental Health, 2014, vol. 1, no. 4, pp. 87-94.

50. Khan S.A., Khan L., Hussain I., Marwat K.B. Profile of Heavy Metals in Selected Medicinal Plants. Pakistan Journal of Weed Science Research, 2008, vol. 14, no. 1-2, pp. 101-110.

51. Ata S., Tayyab S., Rasool A. Analysis of Non-volatile Toxic Heavy Metals $(\mathrm{Cd}, \mathrm{Pb}, \mathrm{Cu}, \mathrm{Cr}$, and $\mathrm{Zn}$ ) in Allium sativum (Garlic) and Soil Samples Collected from Different Locations of Punjab, Pakistan by Atomic Absorption Spectroscopy. E3S Web of Conferences, 2013, no. 16004, pp. 1-3. DOI: $10.1051 / \mathrm{e} 3$ sconf/20130116004

52. Wierzbicka M. How lead loses its toxicity to plants. Acta Societatis Botanicorum Poloniae, 1995, no. 64, pp. 81-90. DOI: 10.5586/asbp.1995.012

53. Alloway B.J., Ayres C.D. Chemical Principals of environmental pollutions, ( $2^{\text {nd }}$ edition). London, American Society of Agronomy, 1997, pp. 545-567.

54. Tasrina R.C., Rowshon A., Mustafzur A.M.R., Rafqu I., Ali M.P. Heavy metal contamination in vegetables and its growing soil. Environmental Analytical Chemistry, 2015, vol. 2, no. 3, pp. 142-147. DOI: $10.4172 / 2380-2391.1000142$

55. Singh A., Sharma R.K., Agrawal M., Marshall F. Risk assessment of heavy metal toxicity through contaminated vegetables from wastewater irrigated area of Varanasi, India. Tropical Ecology, 2010, vol. 51, pp. 375-387.

56. Evaluation of certain food additives and contaminants. Geneva, World Health Organization, 2004, 109 p.

57. Huang M., Zhou S., Sun B., Zhao Q. Heavy metals in wheat grains: assessment of potential health risk for inhabitants in Kunshan, China. Science of the Total Environment, 2008, vol. 1, no. 405 (1-3), pp. 54-61. DOI: 10.1016/j.scitotenv.2008.07.004

58. Agency for Toxic Substances and Disease Registry. ATSDR. Available at: https://www.atsdr.cdc. gov/az/c.html_(19.02.2021).

Feseha A., Chaubey A.K., Abraha A. Heavy metal concentration in vegetables and their potential risk for human health. Health Risk Analysis, 2021, no. 1, pp. 68-81. DOI: 10.21668/health.risk/2021.1.07.eng

Received: 29.01 .2021

Accepted: 15.03 .2021

Published: 30.03.2021 
UDC 613.6.027

DOI: $10.21668 /$ health.risk/2021.1.08.eng

Research article

\title{
METHODICAL APPROACHES TO ASSESSING INDIVIDUAL OCCUPAITONL HEALTH RISK CAUSED BY WORK-RELATED DISEASES DURING THE WHOLE EMPLOYMENT PERIOD
}

\author{
P.Z. Shur, N.V. Zaitseva, V.A. Fokin, D.A. Kiryanov, A.A. Khasanova
}

Federal Scientific Center for Medical and Preventive Health Risk Management Technologies, 82 Monastyrskaya Str., Perm, 614045, Russian Federation

An increase in retirement age means that employment period is prolonged; it calls for preserving people's working capacities for a longer period of time including those with long-term working experience. It is especially vital when it comes to adverse working conditions that might cause high health risks for workers due to work-related diseases.

We suggested methodical approaches to determining individual occupational health risks; these approaches took into account occupationally induced negative responses to impacts exerted by work-related factors; pathogenetic mechanisms of health disorders occurrence; gravity of health disorders; workers' age and working experience. To implement these approaches, we applied a set of procedures that included hygienic and epidemiologic analysis, clinical and laboratory examination of workers, mathematic modeling and prediction.

We tested these approaches via assessing occupational health risks for workers employed at oil-extracting enterprises and it allowed us to determine parameters of dependence between changes in arterial hypertension predictors under exposure to occupational noise and changes in age and working experience $\left(b_{0}=0.1427 ; b_{1}=0.007 ; b_{2}=-0.372\right)$. The obtained parameters can be used in assessing risks of arterial hypertension occurrence due to exposure to occupational noise for workers employed in oil extraction.

Individual occupational risk caused by arterial hypertension in people exposed to occupational noise was higher than its permissible level $\left(1 \cdot 10^{-3}\right.$ ) for 13\% workers (33 people) aged from 41 to 52 and working experience from 19.8 to 33 years; the risk detected in our research amounted up to $2.4 \cdot 10^{-2}$.

Maximum individual risks of work-related arterial hypertension that are predicted to occur at an age close to 59 years amount up to $4.3 \cdot 10^{-2}$ and they will be higher than permissible levels for $56.6 \%$ работников; at an age close to 65 years, up to $4.7 \cdot 10^{-2}$, and they will be higher than permissible levels for $64.8 \%$ workers.

Key words: individual occupational risk, risk assessment, work-related diseases, cardiovascular diseases, arterial hypertension, occupational factors, noise, labor hardness.

In 2019 in Russia average life expectancy reached its historical maximum and amounted to 73.6 years [1]. An increase in life expectancy, together with birth rate going down, gave grounds for a legislative decision ${ }^{1}$ to increase retirement age. Retirement at older age makes it necessary to provide conditions for workers' health preservation and improvement, decrease in morbidity with non-communicable diseases, and reducing disability at pre-retirement age [2].

Retirement at older age extends a period during which people remain employable and it can result in such a negative outcome as longer

(C) Shur P.Z., Zaitseva N.V., Fokin V.A., Kiryanov D.A., Khasanova A.A., 2021

Pavel Z. Shur - Doctor of Medical Sciences, Academic Secretary (e-mail: shur@fcrisk.ru; tel.: +7 (342) 238-33-37; ORCID: https://orcid.org/0000-0001-5171-3105).

Nina V. Zaitseva - Academician of the Russian Academy of Sciences, Doctor of Medical Sciences, Professor, Scientific Director (e-mail: znv@fcrisk.ru; tel.: +7 (342) 237-25-34; ORCID: https://orcid.org/0000-0003-2356-1145).

Vladimir A. Fokin - Researcher at the Health Risk Analysis Department (e-mail: fokin@fcrisk.ru; tel.: +7 (342) 238-33-37; ORCID: https://orcid.org/0000-0002-0539-7006).

Dmitrii A. Kiryanov - Candidate of Technical Sciences, Head of the Department of Mathematical Modeling of Systems and Processes (e-mail: kda@fcrisk.ru; tel.: +7 (342) 237-18-04; ORCID: https://orcid.org/0000-0002-5406-4961).

Anna A. Khasanova - Junior Researcher in the Health Risk Analysis Department (e-mail: KhasanovaAA@inbox.ru; tel.: +7 (342) 238-33-37; ORCID: https://orcid.org/0000-0001-7438-0358).

${ }^{1}$ On making alterations into specific legislative acts of the Russian Federation on granting and paying retirement pensions: The Federal Law issued on October 03, 2018 No. 350-FZ. KonsultantPlus. Available at: http://www.consultant.ru/document/cons_doc_LAW_308156/(06.06.2020)(in Russian). 
exposure to adverse occupational factors and, consequently, greater occupational health risks. And occupational risks here are determined not only by occupational diseases but also work-related ones [3]. Diseases of the circulatory organs are the most widely spread work-related diseases that lead to the greatest losses of working activities due to temporary disability [4].

Occurrence of work-related diseases to a great extent depends on individual features a worker has such as his or her initial health, age, working experience under exposure to adverse occupational factors etc. [5-7]. Individual features should be taken into account when assessing occupational risks together with exposure to adverse occupational factors as it allows establishing personified health risks levels practically for each individual worker. It is vital for developing activities aimed at risks reduction, especially medical and preventive ones.

Certain functional disorders associated with pathogenetic mechanisms of their development usually occur prior to most diseases [8]. To assess such disorders, experts use predictors, or disease occurrence indicators [9]. Analysis of predictors frequency in an examined group can be used for assessing probability of a disease prior to its clinical manifestation; it makes for obtaining more precise health risk assessment, including occupational risks.

Contemporary methodical approaches to occupational risk assessment allow assigning it into specific categories using labor conditions ranks or classes and occupational diseases index. They give grounds for assessing causeand-effect relations between health disorders and work. But at the same time, issues related to quantitative assessment of occupational risks caused, among other things, by work-related diseases have not been resolved completely. Also, there is still a lot to be studied when it comes to assessing individual health risks for each worker taking into account his or her individual health, age, and working experience.

Given that, it seems vital to further develop methodical approaches to assessing and predicting occupational health risks taking into account workers' individual features. Results obtained via assessing individual occupational health risks will provide more solid grounds for organizational and technical, administrative and legal, and, above all, medical and preventive activities aimed at their management during the whole employment period and will make such activities more efficient. It is advisable to test the suggested approaches to individual occupational health risk assessment involving workers who have to perform their work tasks under exposure to a set of adverse occupational factors with some of them exceeding hygienic standards. Such a situation exists in oil extraction industry since workers employed in the brunch suffer from both occupational diseases (sensorineural hearing loss) and work-related ones (arterial hypertension) and these diseases prevent them from continuing their working activities [10].

Our research goal was to develop and test methodical approaches to assessing individual occupational health risks caused by work-related diseases taking into account workers' age, working experience, and exposure to adverse occupational factors.

Data and methods. Individual occupational health risks were assessed as per the following algorithm:

- analyzing data on working conditions;

- performing epidemiologic analysis of workers' health parameters in order to assess cause-and-effect relations between health disorders and work;

- accomplishing clinical and laboratory tests aimed at examining workers' health;

- assessing cause-and-effect relations between health disorders and work;

- building up mathematical models showing dependence between negative responses probability and working conditions, age, and working experience;

- applying the obtained models to calculate individual health risks caused by workrelated diseases.

We suggest methodical approaches to assessing individual occupational health risks that involve using several procedures including:

1. Analysis of data on working conditions (data obtained via specific assessment of 
working conditions, industrial laboratory supervision), workers' age and working experience, assessment of working conditions category in accordance with R 2.2.2006-05 «Guide on hygienic assessment of occupational factors and factors related to labor process» ${ }^{2}$, assigning risks into specific categories according to R 2.2.1766-03 «Guide on assessing occupational health risks for workers. Organizational and methodical grounds, principles, and assessment criteria» ${ }^{3}$.

2. Epidemiologic analysis of workers' health in order to assess cause-and-effect relations between health disorders and work (occupational causation) as per such criteria as risk ratio (RR) and etiological fraction (EF) of negative responses.

3. Clinical and laboratory tests aimed at detecting any predictors (determined via literature sources analysis) of work-related diseases; these tests were performed by experts from the Common and Occupational Pathology Department (headed by O.Yu. Ustinova, Doctor of Medical Sciences, Deputy Director responsible for clinical research), the Department for Biochemical and Cytogenetic Diagnostics (headed by M.A. Zemlyanova, Doctor of Medical Sciences), the Department for Immune and Biological Diagnostics (headed by O.V. Dolgikh, Doctor of Medical Sciences).

Our next task was to establish dependence between development of work-related diseases and exposure to occupational noise; to do that, we built logistic regression models that showed dependence between a probability of negative responses and working conditions, age, and working experience (Formula 1). These models quantitatively determine dependence between a probability that there will be a deviation from physiological standards in predictors characterizing mechanisms of workrelated diseases and an exposure factor, age, and working experience.

$$
p_{1}=\frac{1}{1+e^{-\left(b_{0}+b_{1} x_{1} \cdot x_{2}+b_{2} x_{3}\right)}}
$$

where $\mathrm{p}_{1}$ is a probability that predictors will deviate from physiological standards;

$x_{1}$ is a level of exposure to a certain factor;

$x_{2}$ is working experience;

$x_{3}$ is age;

$b_{0}, b_{1}, b_{2}$ are parameters included into a mathematical model.

Parameters included into a mathematical model were determined via least-square procedure and with specific software for statistical data analysis (Statistica-6.0). Parameters authenticity and model adequacy were assessed basing on one-factor dispersion analysis as per Fischer's test. When building models, we tested both statistical hypotheses and obtained dependences in order to estimate their biological adequacy.

To establish correlations between changes in predictors of diseases and morbidity levels (to assess actual realization of pathogenetic mechanisms), we determined a probability that work-related diseases might occur in workers who had certain signs of negative effects (predictors) developing in their bodies. This probability was determined as frequency of diseases in groups of workers with negative effects developing in them and without such effects.

Individual health risk caused by certain work-related diseases $\left(R_{w-r}^{i}\right)$ was determined as per Formula 2.

$$
R_{w-r}^{i}=p_{1} \cdot p_{2}^{i} \cdot G^{i}
$$

where $p_{1}$ is a probability that predictors will deviate from physiological standards taking into account worker's age;

$p_{2}$ is a probability that $i$-th work-related disease might occur in workers who have signs of negative effects (predictors) developing in their bodies;

$G$ is gravity of $i$-th work-related disease.

\footnotetext{
${ }^{2} \mathrm{R}$ 2.2.2006-05. Guide on hygienic assessment of occupational factors and factors related to labor process. Criteria and working conditions classification. Approved by the RF Chief Sanitary Inspector on July 29, 2005, 142 p. (in Russian).

${ }^{3} \mathrm{R}$ 2.2.1766-03. Guide on assessing occupational health risks for workers. Organizational and methodical grounds, principles, and assessment criteria. KODEKS: an electronic fund for legal and reference documentation. Available at: http://docs.cntd.ru/document/901902053 (06.06.2020) (in Russian).
} 
Acceptable (permissible) occupational health risk was taken as being equal to $1 \cdot 10^{-3}$.

Results and discussion. Suggested approaches were tested via examining impacts exerted by working conditions on health of workers employed in oil extracting industry.

When testing the suggested algorithm, we assessed working conditions as per results obtained via industrial supervision and specific assessment of working conditions performed at 60 workplaces (256 operators dealing with oil and gas extraction in the test group and 37 engineers in the reference group).

Data on workers' health, diseases they suffered from, and clinical-laboratory predictors of work-related diseases were obtained via specific medical examination; we also obtained relevant data via analyzing medical aid appeal ability. According to data taken from literature sources, pro-hypertensive effects produced by occupational noise directly depend on its intensity, frequency, and duration of exposure to it $^{4}$. Changes in the circulatory system caused by exposure to intense occupational noise usually involve neural-circulatory syndrome occurrence and oxidative stress developing together with hypertensive reactions and a trend for transforming into arterial hypertension [11]. Several observation indicate that there are mechanisms underlying functional disorders in the cardiovascular system; these mechanisms, among other things, include endothelial dysfunction and arterial stiffness and are considered to be early signs of damage to vessels occurring due to arterial hypertension [12-15]. It is endothelial dysfunction that is seen as the basic predictor of cardiovascular diseases [16-19].

We examined malonic dialdehyde in blood plasma (293 samples), hydrocortisone (106 samples), lipid hydroperoxide (68 samples), and adrenalin (61 samples) as predictors for work-related arterial hypertension; these predictors changed during actual realization of such pathogenetic mechanisms as oxidative stress, vegetative dysfunction, astheno-vegetative syndrome, and peripheral angiodystonic syndrome [11].

Operators dealing with oil and gas extraction were chosen as our basic research objects since their occupation involved exposure to adverse occupational factors existing at their workplaces. All the workers accomplished similar work tasks under the same working regime.

We established that the examined workers were exposed to the following hazardous and adverse occupational factors: physical, chemical, and psycho-physiological ones ${ }^{5}$. Workers who directly dealt with oil extraction and preliminary oil processing had to perform their work tasks under combined exposure to occupational noise, hazardous chemicals, and adverse parameters of labor hardness. Adverse chemical factors at workplaces predominantly included substances belonging to 2-4 hazard category (oil and its components, and hydrogen sulphide as well). As per results obtained via assessment of working conditions performed at the examined enterprise, working conditions at $100.0 \%$ workplaces of operators dealing with oil and gas extraction were estimated as harmful according to the Guide R 2.2.2006-05 «The Guide on hygienic assessment of factors related to working environment and labor processes. Criteria and classification of working conditions». As per results obtained via specific assessment of working conditions, noise achieved 80-85 $\mathrm{dBA}$ at workplaces (its hygienic standard is $80 \mathrm{dBA}$ ); labor hardness was ranked as harmful working conditions, I-II degree; dihydrosulphide concentrations estimated as per laboratory control reached simple maximum peaks equal to $6.9 \mathrm{mg} / \mathrm{m}^{3}$ (the hygienic standard is $3 \mathrm{mg} / \mathrm{m}^{3}$ ). But still, monitoring observations over aromatic hydrocarbons (benzene, toluene, ethyl-benzene, and xylol) contents in working area air didn't reveal any concentrations exceeding maximum single and average shift maximum permissible ones (MPC) during the whole observation period.

\footnotetext{
${ }^{4}$ O.Yu. Kuz'mina. Clinical and epidemiological peculiarities of metabolic syndrome in patients suffering from workrelated diseases: abstract of the thesis ... for Candidate of Medical Sciences degree. Samara, 2009, 24 p. (in Russian).

${ }^{5}$ GOST 12.0.003-74. The system for labor safety standards. Hazardous and adverse occupational factors. Classification. KODEKS: an electronic fund for legal and reference documentation. Available at: http://docs.cntd.ru/document/gost-12-0-00374-ssbt (06.06.2020) (in Russian).
} 
Table 1

Classification of working conditions as per results obtained via assessing workplaces of operators dealing with oil and gas extraction according to P 2.2.2006-05

\begin{tabular}{|c|c|c|c|c|c|c|c|c|}
\hline \multirow{2}{*}{$\begin{array}{c}\text { Working } \\
\text { area }\end{array}$} & Occupation & \multicolumn{6}{|c|}{ Working conditions category as per intensity of exposure to factors } & Overall \\
\cline { 3 - 9 } & Chemical & $\begin{array}{c}\text { Noise } \\
\text { (Lequiv.) }\end{array}$ & $\begin{array}{c}\text { Micro- } \\
\text { climate }\end{array}$ & $\begin{array}{c}\text { Lighting } \\
\text { environment }\end{array}$ & $\begin{array}{c}\text { Labor } \\
\text { hardness }\end{array}$ & $\begin{array}{c}\text { Labor } \\
\text { intensity }\end{array}$ & $\begin{array}{c}\text { assess- } \\
\text { ment }\end{array}$ \\
\hline 1 & Operator, $4^{\text {th }}$ grade & 3.1 & $2-3.1$ & 2 & 2 & $3.1-3.2$ & 2 & 3.2 \\
\hline 2 & Operator, $5^{\text {th }}$ grade & 3.1 & $2-3.1$ & 2 & 2 & $3.1-3.2$ & 2 & 3.2 \\
\hline 3 & Operator, $6^{\text {th }}$ grade & 3.1 & $2-3.1$ & 2 & 2 & $3.1-3.2$ & 2 & 3.2 \\
\hline
\end{tabular}

Noise, labor hardness, and chemical factor (dihydrosulphide mixed with hydrocarbons) are basic occupational factors that exert their influence on workers and determine occupational health risks.

Working conditions at workplaces of engineers were estimated as harmful at $100.0 \%$ of such workplaces (working conditions category is 3.1). Labor intensity was the basic occupational factor that allowed ranking working conditions at engineer' workplaces as harmful.

According to the Guide R 2.2.1766-03 operators dealing with oil and gas extraction had average (significant) occupational health risks at their workplaces; engineers, small (moderate) risks.

Labor hardness together with elevated noise levels make for developing sensorineural hearing loss due to disorders in cerebral hemodynamics [20]. Apart from this, labor hardness accelerates degenerative-dystrophic processes in the spinal column and makes for more frequent polysegmental osteochondrosis occurrence [21].

We established structure of morbidity in both occupational groups basing on the medical examination as well as data on morbidity among workers provided by the administrative staff at the examined enterprise. A significant number of workers, namely $11.8 \%$, had disorders of the musculoskeletal system (various dorsopathy and osteoarthritis). Cardiovascular diseases accounted for another significant $15.5 \%$ share (hypertensive disease with predominant damage to the heart without heart failure, vascular headache, varicose veins on lower extremities); gastric diseases accounted for $5.3 \%$ (gastroduodenitis, cholecystitis, pancreatic diseases); a big share of $20.9 \%$ be- longed to respiratory diseases (pharyngitis, rhinitis, bronchitis, and tonsillitis). Apart from the above mentioned diseases, some workers from the test group also had disorders of the vegetative (autonomous) nervous system $(1.99 \%)$. There were no occupational diseases detected among the examined workers.

Occupational causation of diseases among operators dealing with oil and gas extraction was confirmed only for essential (primary) hypertension (RR - 2.02; EF \% - 50.57, average occupational causation, $\left.\chi^{2}-3.92\right)$. We didn't detect any relations between other diseases and occupation.

Deviations in predictors that changed due to oxidative stress and vegetative dysfunction thus resulting in arterial hypertension occurrence were revealed in $51 \%$ operators and $37 \%$ engineers.

Mathematical modeling allowed obtaining parameters for dependence between changes in arterial hypertension predictor (hydrocortisone concentration) under exposure to occupational noise and changes in age and working experience $\left(b_{0}=0.1427 ; b_{1}=0.007 ; b_{2}=-0.372\right)$. These parameters were used in assessing risks of arterial hypertension occurrence due to exposure to occupational noise.

Probability of arterial hypertension occurrence with changes in the selected predictor (10 people out of 121) amounted to 0.083 . Arterial hypertension gravity $(G)$ was equal to $0.578[22,23]$.

The suggested methodical approaches to determining individual occupational health risk take into account occupational causation of negative responses to impacts exerted by occupational factors, pathogenetic mechanisms of health disorders occurrence, their gravity, as 
well as workers' age and working experience. They allowed us to establish individual risks of work-related arterial hypertension for workers from the test group.

Individual risk of work-related arterial hypertension (among workers exposed to occupational noise) exceeded permissible level $\left(1 \cdot 10^{-3}\right)$ for workers aged from 41 to 52 with working experience ranging from 19.8 to 33 years (33 people, $13 \%$ of the test group) and varied from $1 \cdot 10^{-3}$ to $2.4 \cdot 10^{-2}$ and it was significantly (up to 24 items) higher than the permissible level for workers with the longest working experience equal to 33 years.

Table 2 contains data on individual risks of work-related arterial hypertension occurrence for workers from the test group.

Individual risk of work-related arterial hypertension that is predicted to occur by the age of 59 is higher than permissible level for $56.6 \%$ workers (145 people) with their working experience being from 29.8 to 41.2 years and varies from $1 \cdot 10^{-3}$ to $43 \cdot 10^{-3}$ and it is significantly (up to 43 times) higher than permissible level.

Individual risk of work-related arterial hypertension that is predicted to occur by the age of 65 is higher than permissible level for $64.8 \%$ workers (166) people with their working experience being from 34.4 to 47.2 and varies from $1 \cdot 10^{-3}$ to $4.7 \cdot 10^{-2}$ and it is significantly (up to 47 times) higher than permissible level.

Therefore, having tested methodical approaches to assessing individual occupational health risks caused by exposure to adverse occupational factors, we were able to prove that these approaches allowed both quantitatively assessing risks for individual workers and predicting their levels for the whole employment period.
Conclusion. In this work we suggest methodical approaches to establishing individual occupational health risks caused by workrelated diseases; these approaches take into account occupational causation of negative responses to impacts exerted by occupational factors, pathogenetic mechanisms of health disorders occurrence, their gravity, as well as workers' age and working experience.

We tested these approaches in assessing occupational risks for workers employed in oil extraction and established parameters for dependence between changes in predictors of work-related arterial hypertension (hydrocortisone contents) under exposure to occupational noise and changes in age and working experience $\left(b_{0}=0.1427 ; b_{1}=0.007 ; b_{2}=-0.372\right)$. These parameters can be used in assessing risks of arterial hypertension occurrence due to exposure to occupational noise for workers employed in oil extracting industry.

The suggested approaches allow quantitatively assessing risk levels for individual workers and predicting them for the whole employment period. Thus, individual risks of work-related arterial hypertension (for workers exposed to occupational noise) exceeded permissible level $\left(1 \cdot 10^{-3}\right)$ for $13 \%$ workers (aged from 41 to 52 and with working experience varying from 19.8 to 33 years) at the moment the research was accomplished and amounted up to $2.4 \cdot 10^{-2}$. Maximum individual risks of work-related arterial hypertension predicted by the age of 59 will amount up to $4.3 \cdot 10^{-2}$ and will be higher than permissible levels for $56.6 \%$ workers; by the age of 65 they will rise up to $4.7 \cdot 10^{-2}$ and they will be higher than permissible levels for $64.8 \%$ workers.

Table 2

Individual risks of work-related arterial hypertension for workers from the test group

\begin{tabular}{|l|c|c|c|}
\hline \multicolumn{1}{|c|}{ Age } & $\begin{array}{c}\text { Working experience range } \\
\text { for workers facing risks } \\
\text { higher than permissible level }\end{array}$ & $\begin{array}{c}\text { Risk values higher } \\
\text { than permissible } \\
\text { one }\end{array}$ & $\begin{array}{c}\text { A share of people with risks } \\
\text { higher than permissible } \\
\text { one (\%) }\end{array}$ \\
\hline $\begin{array}{l}\text { From 41 to 52 years (at the moment the } \\
\text { research was accomplished) }\end{array}$ & $19.8-33$ & $0.001-0.024$ & 13 \\
\hline By the age of 59 & $29.8-41.2$ & $0.001-0.043$ & 56.6 \\
\hline By the age of 65 & $34.42-47.17$ & $0.001-0.047$ & 64.8 \\
\hline
\end{tabular}


Medical and preventive activities were suggested for workers with unacceptable individual health risks of work-related arterial hypertension at the moment the research was accomplished. These activities included an extended medical examination aimed at determining values of arterial hypertension predictors (hydrocortisone, lipid hydroperoxide, and malonic dialdehyde in blood plasma), more efficient personal protection equipment (that is able to reduce noise exposure by 10 and more $\mathrm{dBA}$ ), and revised work and leisure regimes.

Funding. The research was not granted any sponsor support.

Conflict of interests. The authors declare there is no any conflict of interests.

\section{References}

1. Prodolzhitel'nost' zhizni v Rossii dostigla istoricheskogo maksimuma [Life expectancy in Russia has reached its historical maximum]. KarelInform, 2020. Available at: https://karelinform.ru/news/ society/22-04-2020/prodolzhitelnost-zhizni-v-rossii-dostigla-istoricheskogo-maksimuma (15.05.2020) (in Russian).

2. Gundarov I.A., Safonov A.L. Goals of the health service and trade unions to overcome the human resources population crisis in Russia. Trud i sotsial'nye otnosheniya, 2015, no. 4, pp. 23-35 (in Russian).

3. Professional'nyi risk. Teoriya i praktika rascheta: monografiya [Occupational risk. Theory and practice of calculating it: a monograph]. In: A.G. Khrupacheva, A.A. Khadartseva eds. Tula, Izd-vo TulGU Publ., 2011, 330 p. (in Russian).

4. Leonov S.A., Son I.M., Moravskaya S.V. Dynamics of morbidity with a temporary disability in Russian Federation in the period of 2007-2011 years. Menedzher zdravookhraneniya, 2013, no. 8, pp. 6-14 (in Russian).

5. Izmerov N.F., Bukhtiyarov I.V., Prokopenko L.V., Kuz'mina L.P. Protecting health of workers and predictive preventive personified medicine. Meditsina truda i promyshlennaya ekologiya, 2013, no. 6, pp. 7-12 (in Russian).

6. Luzhnikov E.A. Klinicheskaya toksikologiya [Clinical toxicology]. $2^{\text {nd }}$ edition. Moscow, Meditsina Publ., 1994, 256 p. (in Russian).

7. Zinkin V.N., Dragan S.P., Solntsev V.I., Kotlyar-Shapirov A.D., Kondrat'eva E.A. Tekhnologii personal'nogo monitoring i optimizatsii uslovii truda rabotnikov «shumovykh professii» [Technologies for individual monitoring and working conditions optimization for workers with «noisy occupations»]. Bezopasnost' zhiznedeyatel'nosti: vyzovy i ugrozy sovremennosti, nauka, obrazovanie, praktika, 2015, pp. 344-348 (in Russian).

8. Kazimirova O.V., Gazalieva M.A. Prospects for the study of comorbid states in clinical medicine. Meditsina i ekologiya, 2017, vol. 84, no. 3, pp. 8-16 (in Russian).

9. Rybina T.M., Sushinskaya T.M., Chubrik S.M., Rybina A.L., Gin'ko I.V., Iovve A.V. Sovremennye podkhody $\mathrm{k}$ otsenke personal'nogo professional'nogo riska $\mathrm{v}$ khimicheskikh proizvodstvakh [Contemporary approaches to assessing individual occupational health risks at chemical productions]. Zdorov'e i bezopasnost' na rabochem meste: materialy II mezhdunarodnogo nauchnogo foruma, 2017, pp. 217 (in Russian).

10. Fedosov A.V., Zakirova Z.A., Guseva I.E. Professional'nye riski rabotnikov neftyanoi promyshlennosti [Occupational health risks for workers employed in oil industry]. Bezopasnost' truda $v$ promyshlennosti, 2016, no. 6, pp. 70-73 (in Russian).

11. Frol'kis V.V. Biologiya stareniya [Biology of ageing]. Moscow, Nauka Publ., 1982, 616 p. (in Russian).

12. Movergoz S.V., Bulycheva E.V., Setko N.P. Physiological and hygienic characteristics of risk factors of development of arterial hypertension in machinists of petrochemical enterprise. Orenburgskii meditsinskii vestnik, 2018, vol. 6, no. 4 (24), pp. 31-34 (in Russian).

13. Park S. Role of Inflammation in the Pathogenesis of Arterial Stiffness. Yonsei Med J, 2012, vol. 53, no. 2 , pp. $258-261$. DOI: $10.3349 /$ ymj.2012.53.2.258 
14. Steppan J., Barodka V., Berkowitz D.E., Nyhan D. Vascular Stiffness and Increased Pulse Pressure in the Aging Cardiovascular System. Cardiology Research and Practice, 2011, vol. 2011, pp. 263585. DOI: $10.4061 / 2011 / 263585$

15. Kulikov V.P. Ul'trazvukovaya diagnostika sosudistykh zabolevanii [Ultrasound diagnostics of cardiovascular diseases]. Moscow, OOO Firma «Strom» Publ., 2007, 512 p. (in Russian).

16. Kobalava Zh.D., Kotovskaya Yu.V., Moiseev B.C. Arterial'naya gipertoniya. Klyuchi k diagnostike i lecheniyu [Arterial hypertension. Keas to its diagnostics and treatment]. Moscow, GEOTARMedia Publ., 2009, 864 p. (in Russian).

17. Suchkov I.A. Correction of endothelial dysfunction: current status of the problem (literature review). Rossiiskii mediko-biologicheskii vestnik imeni akademika I.P. Pavlova, 2012, vol. 20, no. 4, pp. 151-157 (in Russian).

18. Kirichuk V.F., Glybochko P.V., Ponomareva A.I. Disfunktsiya endoteliya [Endothelial dysfunction]. Saratov, Izd-vo Saratovskogo med. un-ta Publ., 2008, 129 p. (in Russian).

19. Hedner T., Hansson L., Himmelmann A. Endothelial Dysfunction - A Challenge for Hypertension Research. Blood Pressure, 2000, vol. 9, no. 1, pp. 2-3. DOI: 10.1080/080370500439353

20. Versari D., Daghini E., Virdis A., Ghiadoni L., Taddei S. Endothelial Dysfunction as a Target for Prevention of Cardiovascular Disease. Diabetes Care, 2009, vol. 32, no. 2, pp. 314-321. DOI: $10.2337 / \mathrm{dc} 09-\mathrm{S} 330$

21. Dedunov S.V. Osobennosti sochetannogo deistviya shuma i vibratsii na formirovanie professional'noi sensonevral'noi tugoukhosti [Peculiarities of combined effects produced by noise and vibration on occupational sensorineural hearing loss occurrence]. Sbornik materialov mezhdunarodnoi nauchnoprakticheskoi konferentsii «Zdorov'e i okruzhayushchaya sreda». In: N.P. Zhukova ed. Minsk, 2019, pp. 179-180 (in Russian).

22. Lagutina G.N., Rudakova I.E., Matyukhin V.V., Shardakova E.F. Occupational neuroorthopedical pathology at influence of vibration and physical loading. Byulleten' VSNTs SO RAMN, 2006, vol. 49, no. 3, pp. 87-89 (in Russian).

23. Health risk analysis in the strategy of state social and economical development. In: G.G. Onishchenko, N.V. Zaitseva eds. Moscow, Perm', Izdatel'stvo Permskogo natsional'nogo issledovatel'skogo politekhnicheskogo universiteta Publ., 2014, 738 p. (in Russian).

Shur P.Z., Zaitseva N.V., Fokin V.A., Kiryanov D.A., Khasanova A.A. Methodical approaches to assessing individual occupaitonl health risk caused by work-related diseases during the whole employment period. Health Risk Analysis, 2021, no. 1, pp. 82-89. DOI: 10.21668/health.risk/2021.1.08.eng

Received: 30.09 .2020

Accepted: 17.11 .2020

Published: 30.03.2021 
UDC 613.644: 612.842 .5

DOI: $10.21668 /$ health.risk/2021.1.09.eng

Research article

\section{PHYSIOLOGICAL CRITERIA FOR IMPROVING LABOR INTENSITY CLASSIFICATION USED IN OCCUPATIONAL RISKS ASSESSMENT}

\section{I.V. Bukhtiyarov, O.I. Yushkova, M. Khodzhiev, A.V. Kapustina, A.Yu. Forverts}

Izmerov Research Institute of Occupational Health, 31 Budennogo Ave., 105275, Moscow, Russian Federation

The paper focuses on results of substantiating and selecting informative physiological criteria that can be used for assessing and controlling functional state and working conditions category taking into account physical and nervous-emotional loads borne by CNC- machinery operators. Basing on complex physiological and ergonomic studies and retrospective data analysis, we showed that workers from various occupational groups who dealt with physical labor had to face certain strain over a working shift. Such strains, given long-term working experience, could result in neuromuscular system overstrain and occupational diseases occurrence.

We substantiated and developed informative physiological criteria that allowed assessing and controlling functional state and working capacity as well as working conditions category taking into account occupational activities.

The present research involved using a set of occupational studies, physiological and ergonomic procedures as well as clinical and statistic ones for examining peculiarities related to functional state of workers' bodies under exposure to occupational factors taking into account specific working tasks and loads. It allowed us to substantiate labor intensity assessment.

Our research results revealed that there was a strong correlation between hand muscles endurance to static exertion (decrease in \% by the end of a work shift) and working conditions category given local and overall muscular loads borne by workers. This criterion is recommended for control over functional state and working capacity taking into account occupational peculiarities and gender-related differences. It is necessary to accumulate scientific data for confirming a similar correlation between overall physical working capacity (OPWC) and working conditions category. Results obtained via physiological research were used for developing prevention activities for workers.

Key words: physiological criteria, classification, labor intensity, physical and nervous and emotional loads, working conditions category, functional state, overstrain, prevention.

At present it is still difficult to predict probable changes in workers' health since there hasn't been sufficient research aimed at determining peculiarities related to how workers' functional systems get overstrained depending on labor intensity at contemporary working places. The necessity to create a classification for labor process factors (labor intensity and hardness) occurred long ago; such a classification should include a table with certain criteria for assessing relevant parameters. The first attempt to create such a classification is considered to be made in a publication issued in 1970 by A.V. Vasilyeva, S.I. Gorshkov, M.A. Gritsevskiy et al., well- known occupational physiologists. Their work was entitled «Physiological and hygienic issues related to work and leisure regimes in industry» and was issued for "Work and leisure regimes and shift schedules in leading industrial branches» workshop [1].

The authors were right to note that from biological point of view labor was an important function performed by a human body and it involved certain physiological costs. Physiological costs of work, that is, a degree of body functional strain during labor, is usually called «labor hardness». The more exact approach to scientific terminology indicates that in this case we should speak about physical hardness

(c) Bukhtiyarov I.V., Yushkova O.I., Khodzhiev M., Kapustina A.V., Forverts A.Yu., 2021

Igor V. Bukhtiyarov - Doctor of Medical Science, Director, Professor, Corresponding Member of the Russian Academy of Sciences (e-mail: ivdukhtiyarov@mail.ru; tel.: +7 (495) 365-02-09; ORCID: https://orcid.org/0000-0002-8317-2718).

Olga I. Yushkova - Doctor of Medical Science, Professor, Chief researcher at the Laboratory for Labor Physiology and Preventive Ergonomics (e-mail: doktorolga@inbox.ru; tel.: +7 (916) 541-20-48; ORCID: https://orcid.org/0000-0002-6704-3537).

Makhmadamin Khodzhiev - Candidate of Medical Science, Doctoral student (e-mail: amin.dok59@mail.ru; tel.: +7 (968) 585-12-95; ORCID: https://orcid.org/0000-0002-5116-2486).

Angelina V. Kapustina - Candidate of Biological Science, Senior researcher at the Laboratory for Labor Physiology and Preventive Ergonomics (e-mail: ft-matuhin@mail.ru; tel.: +7 (903) 542-45-74; ORCID: https://orcid.org/0000-0001-8631-0074).

Anna Yu. Forverts - Junior researcher at the Laboratory for Labor Physiology and Preventive Ergonomics, post-graduate students (e-mail: agniia.forverts@gmail.com; tel.: +7 (903) 201-17-82; ORCID: https://orcid.org/0000-0002-3485-5221). 
and nervous strain any labor involves. It can be substantiated by the following.

Functional strain that appears in a body due to labor can schematically be divided into two parts, energy- and information-related ones. The first prevails in case labor is predominantly physical; the second, predominantly intellectual. Physiologists determine labor hardness as loads on a body occurring due to labor that requires muscle efforts and relevant energy support.

Physiologists determine labor intensity as loads on a body occurring due to labor that requires intensive brain work aimed at obtaining and analyzing information.

Later criteria were developed and included into «Hygienic labor classification (as per adverse and hazardous occupational factors, labor hardness and intensity)» (Moscow, 1986) ${ }^{1}$. Labor conditions and character were differentiated in such a way so that it allowed for an extent to which occupational factors and labor-related factors deviated from the existing hygienic standards and influence they exerted on workers' functional state and health. Three categories of labor conditions and character were determined according to those parameters.

There are scientific grounds for assessing labor developed by hygienists and physiologists, namely «Hygienic labor classification» (1986), the Guide R 2.2.013-94 ${ }^{2}$ last edited in $1999^{3}$, and the valid Guide R 2.2.2006-05 «the Guide on hygienic assessment of occupational and labor-related factors. Criteria and working conditions classification $»{ }^{4}$. These works allow assessing labor intensity as per five types of loads: intellectual, sensory, emo- tional, monotonous, and labor regime. However, at present it is often highlighted that this procedure hardly allows obtaining quantitative assessments since it only provides as opportunity to qualitatively determine intellectual or emotional loads etc. for different durations of a working day, differently organized technological cycles, or instable working places.

Changes in character of labor that is now required at up-to-date working places make it necessary to substantiate quantitative criteria for labor intensity assessment; relevant alterations are to be made into regulatory documents (The Federal Law «On special assessment of working conditions» No. 426-FZ issued on December 28, 2013 and the procedure for accomplishing this assessment) ${ }^{5}$.

Labor intensity is determined according to $R$ 2.2.2006-05 when a sanitary-hygienic profile of worker's labor is created in case a medical specialist believes he or she is suffering from an occupational disease (The Order by the RF Ministry for Public Healthcare and Social Development No. 103 issued on November 10, 2009) ${ }^{6}$.

It is also rather difficult to substantiate informative physiological parameters that allow estimating and controlling workers' functional state and working conditions categories (optimal, acceptable, or hazardous).

Data that are available in literature indicate that being prepared to physical activity (physical proficiency) is significant for maintaining efficient work functions during labor activities [2, 3]. Some authors revealed that physical proficiency that was determined bas-

\footnotetext{
${ }^{1}$ Hygienic labor classification (as per adverse and hazardous occupational factors, labor hardness and intensity). Approved by the deputy to the Chief Sanitary Inspector of the USSR Public Healthcare Ministry A.I. Zaichenko on August 12, 1986 No. 4137-86. Moscow, 1986, 11 p. (in Russian).

${ }^{2}$ R 2.2.013-94. Hygienic criteria for assessing labor conditions as per adverse and hazardous occupational factors, labor hardness and intensity. Approved by the first deputy to the Head of the RF State Sanitary Epidemiologic Surveillance Service on July 12, 1994. Moscow, 1994, 131 p. (in Russian).

${ }^{3}$ R 2.2.755-99. Hygienic criteria for labor conditions assessment and classification as per adverse and hazardous occupational factors, labor hardness and intensity. Approved by the RF Chief Sanitarian Inspector on April 23, 1999. Moscow, 1999, 140 p. (in Russian).

${ }^{4}$ R 2.2.2006-05. The Guide on hygienic assessment of occupational and labor-related factors. Criteria and working conditions classification. The Bulletin of regulatory and methodical documents issued by the State sanitary Epidemiologic Surveillance Service. Moscow, 2005, 142 p. (in Russian).

${ }^{5}$ On special assessment of working conditions: The Federal Law issued on December 28, 2013 No 426-FZ. KonsultantPlus. Available at: http://www.consultant.ru/document/cons_doc_LAW_156555/(03.03.2020) (in Russian).

${ }^{6}$ The instruction on how to draw up a sanitary-hygienic profile of working conditions for a worker who is believed to be suffering from an occupational disease: The Order by the RF Ministry for Public Healthcare and Social Development No. 103 issued on November 10, 2009. StandartGost. Available at: https://standartgost.ru/g/base/1/id054468/\%D0\%9F\%D1\%80\%D0\%B8\%D0\%BA\%D0\%B0\%D0\%B7_103 (03.03.2020) (in Russian).
} 
ing on overall physical working capacity (OPWC) was related to fatigue development, that is, to changes in functional state of a worker's leading body systems ${ }^{7}$ [4-6]. People with high OPWC had less apparent changes in their motor and vegetative functions than those with low OPWC. L.V. Abolian, V.V. Matyukhin et al. examined peculiarities related to functional state formation in people with certain occupations and revealed that workers with «high» OPWC tended to have better functional state of their nervous and muscular apparatus, better adaptive responses, and good cardiovascular system capacity [7-10]. It is assumed that OPWC can be used together with other physiological parameters for assessing functional state and control over working conditions category determined as per ergonomic properties. It is possible that dependence between physical proficiency and a degree of functional changes occurs within certain, and as a rule, average, OPWC range. It would be interesting to test whether this hypothesis is valid within another OPWC range.

Our research goal was to take up-to-date occupations as an example and to substantiate and develop informative physiological criteria that allow estimating and controlling workers' functional state and working capacity as well as working conditions category taking into account occupational activities.

Data and methods. To solve all the tasks set within the present work, we applied occupational studies, physiologic-ergonomic and clinical-statistical research procedures for examining peculiarities related to how workers' functional state is formed under exposure to occupational factors taking labor specifics and labor loads into account. It allowed us to try and substantiate approaches to labor intensity assessment.

We examined practically healthy workers from several occupational groups who had to deal with physical (muscular) and nervousemotional loads in their labor activities. Occupational studies and physiological-ergonomic studies were performed involving five occupational groups being made of males (robotic technological complexes (RTC) operators; $\mathrm{CNC}$ machines operators at civil engineering enterprises; steelmen; high riggers who were mostly labor migrants from southern republics; $\mathrm{CNC}$ machines programmers at stone-working enterprises) and two occupational groups made of females employed at a stone-working enterprise in Moscow (CNC stone-working machine operator and CNC grinder operator). Overall, we examined approximately 200 people aged $30.3 \pm 1.0$, with their working experience being equal to $4.8 \pm 0.2$, who worked in morning shifts (three times during a working day).

Occupational profile for each labor activity was drawn up in accordance with the Guide $\mathrm{R}$ 2.2.2006-05. To assess functional state of the nervous-muscular system, we performed dynamometric measurements of hand power and endurance with the following calculation of maximum working capacity (maintained effort being multiplied by duration of this maintenance). Physical proficiency was determined as per OPWC via PWC 170 test and calculated maximum oxygen consumption.

Cardiovascular system examinations involved determining systolic and diastolic blood pressure $\left(\mathrm{BP}_{\max }, \mathrm{BP}_{\min }\right)$ with subsequent calculation of pulse $\left(\mathrm{BP}_{\mathrm{p}}\right)$ and average dynamic (My) blood pressure, heart rate, stroke and minute heart volumes (SHV and MHV), and overall periphery resistance (PR). BP was registered with mercury sphygmomanometer; central hemodynamics parameters were determined via tetrapolar chest rheography. At the beginning and at the end of work there was a physical load test (bicycle ergometer) with load power being $100 \mathrm{WT}$, and an intellectual load test (addition with switching to another activity). Recovery process was written down during 5 minutes after physical loads and during 3 minutes after intellectual ones.

The study was accomplished in conformity with the International Code of Medical Ethics (1949) and Helsinki Declaration on pre-clinical and clinical studies on humans and animals that was approved upon by the World Medical Association (1964). Prior to the study all the par-

\footnotetext{
${ }^{7}$ Matyukhin V.V., Shardakova E.F., Yushkova O.I., Elizarova V.V., Yamplo'skaya E.G., Poroshenko A.S., Kuz'mina L.P. Influence exerted by labor-related factors. «Ekometria» Encyclopedia. Influence exerted on a human body by adverse and hazardous occupational factors. Moscow, Izdatelstvo standartov Publ., 2004, vol. 1, pp. 344-441 (in Russian).
} 
ticipants got acquainted with its procedure and concomitant risks and gave their written informative voluntary consent to take part in it.

We used conventional variation statistics procedures, namely revealing discrepancies between groups using simple means (as per Student's t-test) and correlation analysis (as per Pearson's procedure). All the data were processed with Statistika 6.0 software package ${ }^{8}$.

Results and discussion. Labor hardness caused by a necessity to maintain a forced working posture, to make a lot of deep body bows, and frequently repeated monotonous hand movements etc. aggravates adverse physiological changes in the nervous-muscular system and musculoskeletal system. It can cause not only a decrease in working capacity but also overstrain and pathology occurrence in these systems [11-13].

We assessed labor hardness for $\mathrm{CNC}$ machines operators; the assessment revealed that such parameters as physical dynamic loads (given in units showing external mechanical work, $\mathrm{kg} \cdot \mathrm{m}$ ) and a quantity of monotonous working movement are within optimal range. However, operators have to bend their bodies a lot during work (more than 200 body bending movements over a shift, hazard category 3.1), and an operator has to spend up to $80 \%$ of his working shift standing (hazard category 3.1). Therefore, we can conclude that a $\mathrm{CNC}$ grinder operator has to face working conditions at a workplace that belong to the $3^{\text {rd }}$ class, $2^{\text {nd }}$ hardness degree (hazard category 3.2): $\mathrm{CNC}$ stone-working machine operator and $\mathrm{CNC}$ operator at civil engineering enterprises, 3.1 hazard category; CNC machine programmer and RTC operator, acceptable working conditions, hazard category 2.0.

Physiological research included examining functional state of the nervous-muscular system as being occupationally significant in providing proper working abilities for workers from the examined occupational groups. We detected a decrease in dynamometric parameters over shift dynamics that became especially apparent by the end of a work shift (Table 1). And an extent to which endurance changed depended on working conditions category.
Thus, endurance practically didn't change in RTC operators during the whole work shift.

A decrease in endurance amounted to $20.4 \%$ in CNC machines programmers; $26.4 \%$, in $\mathrm{CNC}$ stone-working machines operators. As labor became harder and more intense, a decrease in endurance by the end of a work shift grew up to $31.0-33.0 \%(p \leq 0.05)$ and it was higher than physiological standards for body strain under physical labor (the parameter should not exceed $20 \%$ under local and overall muscle loads) (see Table 1). Hand force almost didn't change in the examined groups; therefore, changes in maximum muscular working capacity as another parameter showing functional state of the nervous-muscular system were practically the same as changes in endurance.

We compared two types of equipment used at civil engineering enterprises, CNC machines and RTC; the comparison revealed that working with $\mathrm{CNC}$ machinery resulted in greater fatigue in hand muscles than working with RTC. Endurance to static exertion and maximum working capacity of hand muscles fell authentically among CNC machines operators by $21.3 \%(p \leq 0.01)$ and by $21.6 \%(p \leq 0,05)$ already after 4 hours of and by $24.1 \%(p \leq 0.01)$ and $21.6 \%(p \leq 0.05)$ by the end of a work shift accordingly against the initial level. We also revealed insignificant negative dynamics of dynamometric parameters among operators; it can be due to substantial muscle exertion required to move details manually whereas the same operation is performed by a robotmanipulator when a RTC is used.

Researchers revealed that when a person deals with physical labor regardless of muscle loads character (local or overall), his or her functional state and, accordingly, overall working body strain are closely connected to the leading labor-related factors (labor hardness). Excessive loads lead to early signs of fatigue in workers' nervous-muscular system. When a working experience is substantial, long-term performance of such work tasks can result in overstrain in the nervous-muscular system and in frequent occupational diseases; the higher and more intense are loads on

\footnotetext{
${ }^{8}$ Khalafen A.A.. STATISTICA-6. Statistical data analysis. The $3^{\text {rd }}$ edition. Moscow, Binom-Press Publ., 2007,512 p. (in Russian).
} 
Table 1

Changes in hand muscles endurance to static excretion in workers from the examined occuaptional groups taken in shift dynamics

\begin{tabular}{|l|c|c|c|c|}
\hline \multirow{2}{*}{$\begin{array}{l}\text { Occupational group / working conditions } \\
\text { category as per labor hardness }\end{array}$} & \multirow{2}{*}{ Parameter } & \multicolumn{3}{|c|}{ Examination period } \\
\cline { 3 - 5 } & & Beginning of a shift & Middle of a shift & End of a shift \\
\hline \multirow{2}{*}{$\begin{array}{l}\text { RTC operator at civil engineering enter- } \\
\text { prises / hazard category 1 }\end{array}$} & $M \pm m$ & $18.9 \pm 1.1$ & $18.1 \pm 1.3$ & $17.2 \pm 1.7$ \\
\cline { 2 - 5 } & $P$ & - & $>0.05$ & $>0.05$ \\
\hline \multirow{2}{*}{$\begin{array}{l}\text { CNC machine programmer / } \\
\text { hazard category 2 }\end{array}$} & $\%$ & 100 & 95.7 & 91.0 \\
\cline { 2 - 5 } & $M \pm m$ & $21.1 \pm 1.4$ & $18.3 \pm 1.5$ & $16.8 \pm 1.4$ \\
\cline { 2 - 5 } & $\%$ & 100 & $<0.05$ & $<0.05$ \\
\hline \multirow{2}{*}{$\begin{array}{l}\text { CNC stone-working machine operator / } \\
\text { hazard category 3.1 }\end{array}$} & $M \pm m$ & $20.1 \pm 1.1$ & $17.4 \pm 1.3$ & $14.8 \pm 1.7$ \\
\cline { 2 - 5 } & $P$ & - & $>0.05$ & $<0.05$ \\
\hline \multirow{2}{*}{$\begin{array}{l}\text { CNC machine operator at civil engineer- } \\
\text { ing enterprises / hazard category 3.1 }\end{array}$} & $M \pm m$ & 100 & 86.6 & 73.6 \\
\cline { 2 - 5 } & $P$ & - & $14.9 \pm 1.8$ & $14.4 \pm 1.7$ \\
\hline \multirow{2}{*}{$\begin{array}{l}\text { CNC grinder operator / } \\
\text { hazard category 3.2 }\end{array}$} & $M \pm m$ & $21.1 \pm 1.7$ & $17.2 \pm 1.4$ & $13.3 \pm 1.6$ \\
\cline { 2 - 5 } & $P$ & - & $<0.05$ & $<0.01$ \\
\cline { 2 - 5 } & $\%$ & 100 & 82.0 & 69.0 \\
\hline
\end{tabular}

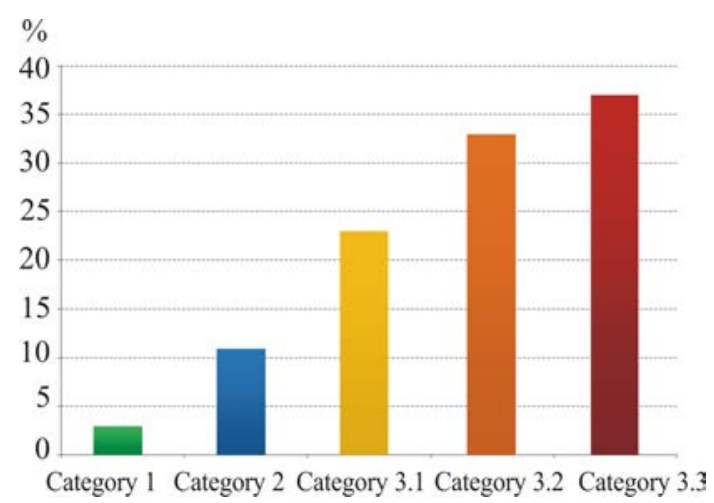

Figure 1. Prevalence of occupational diseases in the nervous-muscular system and musculoskeletal system depending on hazard category as per labor hardness $(\%)$

workers' nervous-muscular system during a work shift, the more probable these negative outcomes become [14-16]. It was convincingly confirmed by results obtained via clinical and functional research. It was established that substantial systematic muscle loads played a potential role in development of occupational diseases with certain etiology. Figure 1 shows prevalence of occupational diseases in the musculoskeletal system depending on labor hardness category.

High physiological strain of the nervousmuscular system that occurs under common physical labor has potential significance for dorsopathy occurrence [17-20]. It was established that systemic overall muscular loads most frequently resulted in such damage to the lumbosacral section as chronic radiculopathy occurrence; it often led to a decrease in occupational working capacity and workers' social deadaptation.

Labor that causes damage to the lumbar spine is most common among builders [21, $22]$. Even in such a well-developed country as Finland up to $20 \%$ workers daily face very grave physical loads despite all technological developments [15]. Multiple studies that focused on health of migrants from the southern republics revealed that as working experience became longer, there was an increase in number of musculoskeletal system disorders; it was caused by such work tasks as lifting and moving heavy weight, working in a forced working posture, etc. Prevalence of such musculoskeletal diseases as, for example, polyosteoarthrosis and polyarthritis, goes down from $32.1 \%$ to $8.9 \%$ (per 100 examined workers) as working experience gets longer; on the contrary, a number of dorsopathy cases grows from 16.8 to $27.0 \%$ among workers with working experience being equal 1-3 years, 7 years, and longer, accordingly. It can be due to substantial physical loads labor migrants have to face.

Results obtained via physiological studies allow considering hand muscle endurance to static exertion to be quite an informative parameter for being used as a criterion when as- 
sessing and controlling functional state and working conditions category in case labor activities involve such loads that labor hardness becomes a leading labor-related factor.

Given hat, Table 2 shows distribution of specific physiological parameters as per working conditions categories (sub-categories) when labor intensity is estimated for different occupational activities.

We also examined another physiological parameter, namely, overall physical working capacity, among CNC machine operator and RTC operators; the examination revealed that there were authentic discrepancies between these two occupational groups as per OPWC and maximum oxygen consumption values. CNC machines operators had average OPWC equal to $25.19 \pm 1.50$; RTC operators, $17.99 \pm$ $0.80 \mathrm{~kg} \mathrm{~m} / \mathrm{min} \mathrm{kg}$ of weight $(p \leq 0.01)$; authentic discrepancies between the groups regarding maximum oxygen consumption were also present $(p \leq 0.01)$.

Assessing workers' physical conditions according to the methodical guidelines ${ }^{9}$ allowed establishing that physical proficiency was above average (high) among CNC machine operators and below average (satisfactory) among RTC operators. These differences seem to be due to labor activities since CNC machine operators have to deal with harder physical labor than RTC operators.

Results obtained via physiologic research revealed that functional state of the cardiovascular system didn't change by the end of a shift in any examined group. At the same time results obtained via tests with loads allowed revealing multi-directional shifts in operators from different occupational groups. SHV curves analysis revealed an adequate response to physical loads among RTC operators both at the beginning and the end of a work shift whereas there was a delayed response among $\mathrm{CNC}$ machines operators. And SHV and MHV didn't recover at the $3^{\text {rd }}$ and $5^{\text {th }}$ minute in CNC machines operators at the end of a work shift after physical loads $(p \leq 0.05)$ and at the $3^{\text {rd }}$ minute after intellectual loads. Periphery resistance as a response to physical loads went down among workers from these two groups and recovery was a bit delayed among CNC machines operators.

CNC machines operators had more apparent responses to physical loads as per BP parameters (maximum, pulse, and average dynamic BP). As we can see from Figure 2, at the beginning of a work shift maximum BP increase authentically more frequently among CNC machines operators against RTC operators $(p \leq 0.05)$. At the $1^{\text {st }}$ recovery minute discrepancies between two groups were substantial $(p \leq 0.05)$, and maximum BP didn't recover at the $3^{\text {rd }}$ and $5^{\text {th }}$ minutes after a test physical load was faced, and at the $1^{\text {st }}$ and $3^{\text {rd }}$ minutes after intellectual loads at the end of a work shift. The same dynamics was detected for pulse and average dynamic blood pressure (see Figure 2).

Comparison made between obtained MHV and PR and physiological standards for the parameters revealed that hyperkinetic

Table 2

Distribution of physiological parameters among workers dealing with physical labor with local and overall loads as per working conditions categories (subcategories) allowing for gender-related differences

\begin{tabular}{|l|c|c|c|c|c|}
\hline \multirow{2}{*}{ Physiological parameter } & \multirow{2}{*}{ gender } & \multicolumn{2}{|c|}{ Wocal and overall loads } \\
\cline { 3 - 6 } & & optimal & acceptable & \multicolumn{2}{c|}{ hazardous } \\
\cline { 3 - 6 } & males & $\leq 20.7$ & $23.8-26.8$ & $26.9-29.9$ & $30.0-33.0$ \\
\cline { 3 - 6 } $\begin{array}{l}\text { Hand muscle endurance to static } \\
\begin{array}{l}\text { exertion (\% of a decrease by } \\
\text { the end of a work shift) }\end{array}\end{array}$ & females & $\leq 21.9$ & $24.3-26.6$ & $26.7-29.0$ & $29.1-31.4$ \\
\hline
\end{tabular}

${ }^{9}$ The Methodical guidelines on assessing physiological standards of human body strain, allowing for genderrelated differences, for different occupational activities (mental, visually strained, physical). Approved on February 26, 2015 by the Scientific Council No. 45 on workers' medical and ecological health issues. Moscow, 2015. (in Russian). 


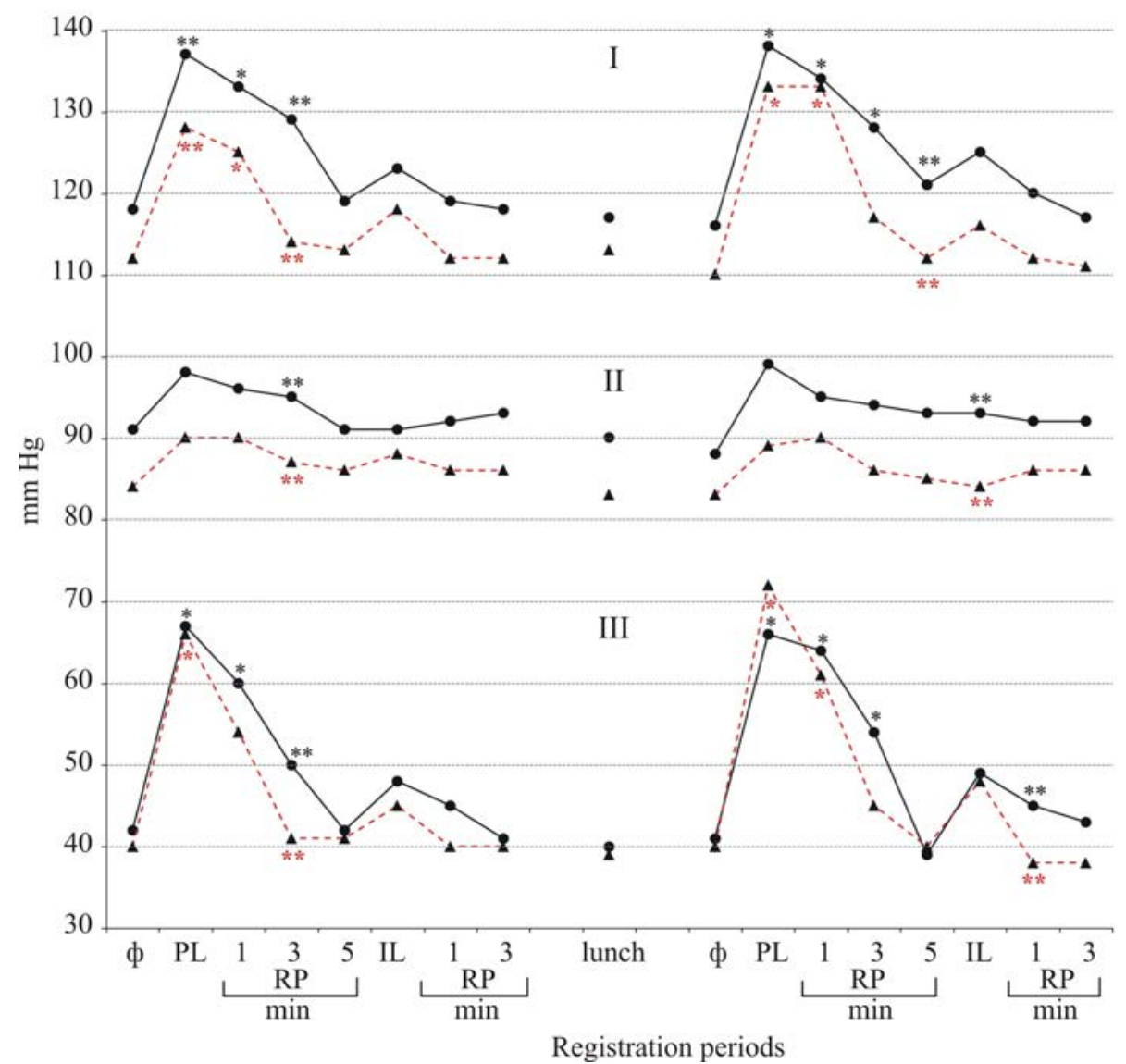

Figure 2. Changes in maximum (I), average dynamic (II), and pulse (III) blood pressure under test loads in operators from two occupational groups

Note: solid line with rounds is for CNC operators; broken line with triangles is for RTC operators; * one asterisk means there are statistic differences form background values; ** two asterisks mean there are authentic discrepancies between the two groups; Y-axis shows blood pressure (mm Hg); X-axis shows registration periods (BP recovery after loads in minutes); $\phi$ means background values; PR is recovery period; PL is physical load; IL is intellectual load.

circulation type ${ }^{10}[23,24]$ prevailed in systemic pressure regulation in operators from the two examined groups. RTC operators tended to have better ration between MHV and RS (an adequate growth and fall in PR under physical loads) that was aimed at optimal circulatory system regulation, in particular, adequate increase in BP. At the same time, CNC machines operators had less apparent changes in MHV and PR with a significant increase in $\mathrm{BP}$ as a response to physical loads and it became especially obvious by the end of a work shift. It indicates there is greater strain in circulatory regulation mechanisms in CNC machines operators. Besides, compensatory mechanisms strain is also more apparent in them that becomes obvious via higher average dynamic blood pressure, and later recovery of $\mathrm{SHV}, \mathrm{MHV}$, and $\mathrm{BP}$ (maximum, pulse, and average dynamic one).

To sum up all the above mentioned, we should note that we detected higher overall physical working capacity among CNC operators and lower OPWC among RTC operators. Labor activities performed by $\mathrm{CNC}$ machines operators involve apparent strain in the nervousmuscular system and it results in early signs (4 hours after a shift started) of developing hand muscle fatigue. Functional state of the cardiovascular system determined as per tests with loads changed more significantly among

\footnotetext{
${ }^{10}$ Instrumental procedures for cardiovascular system examination: a reference book. In: T.S. Vinogradova ed. Moscow, Medistina Publ., 1986, 415 p. (in Russian).
} 
Physiological criteria for improving labor intensity classification used in occupational risks assessment ...

Table 3

A probability that occuaptional pathology might occur (\%) depending on labor hardness and changes in endurance

\begin{tabular}{|c|c|c|c|c|c|}
\hline \multirow{3}{*}{ Parameter } & \multicolumn{5}{|c|}{ Labor hardness } \\
\hline & \multirow{2}{*}{$\begin{array}{l}\text { Category 1, optimal } \\
\text { (slight physical loads) }\end{array}$} & \multirow{2}{*}{$\begin{array}{c}\text { Category 2, acceptable } \\
\text { (average physical loads) }\end{array}$} & \multicolumn{3}{|c|}{ Category 3, hazardous (hard labor) } \\
\hline & & & 3.1 & 3.2 & 3.3 \\
\hline Probability, \% & $0-0.6$ & $6.1-17.0$ & $17.1-28.0$ & $28.1-37.0$ & $\begin{array}{l}\text { Higher than } \\
37.0\end{array}$ \\
\hline \multirow{2}{*}{$\begin{array}{l}\text { Hand muscle endurance } \\
\text { to static exertion, } \% \text { of } \\
\text { a decrease by the end of } \\
\text { a work shift }\end{array}$} & $\begin{array}{c}\text { Males - } \\
\text { lower than } 20.7\end{array}$ & from 20.8 to 23.8 & $\begin{array}{c}\text { from } 23.9 \\
\text { to } 26.8\end{array}$ & $\begin{array}{c}\text { from } 26.9 \\
\text { to } 29.9\end{array}$ & $\begin{array}{l}\text { Higher than } \\
30.0\end{array}$ \\
\hline & $\begin{array}{c}\text { Females - } \\
\text { lower than } 21.9\end{array}$ & from 22.0 to 24.3 & $\begin{array}{l}\text { from } 24.4 \\
\text { to } 26.6\end{array}$ & $\begin{array}{l}\text { from } 26.7 \\
\text { to } 29.9\end{array}$ & $\begin{array}{c}\text { Higher than } \\
31.4\end{array}$ \\
\hline
\end{tabular}

CNC machines operators who had excellent (above average) physical proficiency and it is not in line with conventional opinions. It is known that the greatest decrease in functional capabilities of basic body systems is detected in people with low physical working ability. Obviously, if we want to get an insight into physiological mechanisms behind this phenomenon, we should turn to a regularity established by L.V. Abolyan [7]. He showed in his research that dependence between physical proficiency and functional changes in workers' basic body systems occurred within certain, and as a rule, average, range of overall physical working capacity. When OPWC is «high» as it is the case with CNC machines operators, this dependence doesn't usually hold. Additional studies will be required for understanding this regularity better and for scientific substantiation of OPWC parameter being possibly included as a physiological criterion into assessing and controlling functional state and working conditions category allowing for labor activity type.

Research results revealed that labor hardness was classified as per changes in hand muscle endurance. This endurance parameter is determined as per a decrease in it over a shift measured in $\%$ of its initial value. Distribution of physiological parameters determined for workers dealing with physical labor with local and overall physical loads as pre working conditions categories (sub-categories) taking gender-related differences into account allows assessing probable health risks for workers. We calculated dependence between occupational diseases frequency (2,318 cases were analyzed in retrospect) and labor hardness category under local and overall muscular loads; the calculation allowed determining a regression equation and presenting all the obtained results in Table 3.

All the obtained results indicate that the higher is decrease in endurance, the greater is occupational risk that the above-mentioned pathology occurs. Health disorders are the most probable for workers who have to work under working conditions belonging to the hazard category 3.3; the probability amounts to $37 \%$ in case there is a $30 \%$ decrease in endurance by the end of a work shift among males and a $31.4 \%$ decrease in the parameter among females. Given that, a probability that occupational pathology might occur can be predicted depending on labor hardness category and this prediction can be based on hand muscle endurance to static exertion.

\section{Conclusions:}

1. Research on multiple occupational groups dealing with labor that involved physical and nervously-strained loads allowed establishing that labor-related factors often exceeded acceptable levels for most occupations regardless of load types. Long-term exposure to adverse factors making labor too hard and too intense exerts substantial influence on functional states of workers' body systems, especially, on their nervous-muscular system.

2. Exposure to intense and long-term labor-related factors that exceed acceptable levels (the $3^{\text {rd }}$ hazard category, sub-categories 1-2) results in overstrain occurrence in most workers; this overstrain becomes obvious via substantial changes in physiological parameters taking gender-related differences into account.

3 . Workers dealing with physical labor that involved both local and overall muscular loads tended to have a strong correlation between hand muscle endurance to static exertion $(\%$ of a decrease by the end of a work shift) and working 
conditions category. It allows recommending this parameter for control over functional state and working ability taking into account labor activity type and gender-related differences.

4. Damage to the lumbar spine as an outcome caused by hard working conditions (weight moving and lifting, working in a forced working posture, etc.) is widely spread among builders including labor migrants for the southern republics. A number of musculoskeletal diseases grows as working experience gets longer.

5. We detected that $\mathrm{CNC}$ machines operators tended to have higher overall physical working capacity (OPWC) than RTC operators who had only satisfactory OPWC. Workers with higher OPWC tended to have higher functional capabilities of the nervous-muscular system and apparent strain in circulatory regulation mechanisms when tests with loads were performed.

6. Additional studies are required and obtained data are to be analyzed for revealing dependence between high physical proficiency and functional state of a body and a possibility to use OPWC as a criterion for assessing functional state and working conditions category taking labor activity type into account.

7. Research results allowed establishing a possibility to predict occupational diseases in workers dealing with physical labor as per such a physiological parameter as hand muscle endurance to static exertion. The greater is a decrease in endurance, the higher is a probability that an occupational pathology might occur. Distribution of physiological parameters obtained for workers dealing with physical labor involving local and overall muscular loads as per working conditions categories (sub-categories) taking gender-related differences into account allows assessing health risks for workers.

Funding. The research was not granted any sponsor support.

Conflict of interests. The authors declare there is no any conflict of interests.

\section{References}

1. Vasil'eva A.V., Gorshkov S.I., Gritsevskii M.A. Fiziologicheskie i gigienicheskie voprosy rezhimov truda $\mathrm{i}$ otdykha $\mathrm{v}$ promyshlennosti [Physiological and hygienic issues related to work and leisure regimes in industry]. Rezhimy truda i otdykha i grafiki smennosti $v$ vedushchikh otraslyakh promyshlennost: Materialy simpoziuma. In: V.V. Kulemin ed. Moskva - Ivanovo, 1970, 177 p. (in Russian).

2. Matyukhin V.V., Bukhtiyarov I.V., Yushkova O.I., Shardakova E.F., Kalinina S.A., Elizarova V.V., Yampol'skaya E.G., Poroshenko A.S. Sovershenstvovanie kriteriev otsenki perenapryazheniya i garmonizatsiya standartov fizicheskoi rabotosposobnosti u rabotnikov sovremennykh form truda [Developing criteria for assessing overstrain and harmonizing standards for physical working capacity in workers employed in contemporary working conditions]. Aktual'nye problemy meditsiny truda: sbornik trudov instituta. In: I.V. Bukhtiyarov ed. Moscow, OOO «Melga» Publ., 2015, pp. 38-90 (in Russian).

3. Gridin L.A., Ikhalainen A.A., Bogomolov A.V., Kovtun A.L., Kukushkin Yu.A. Metody issledovaniya i farmakologicheskoi korrektsii fizicheskoi rabotosposobnosti cheloveka [Research procedures and procedures for pharmacological correction of human working capacity]. In: I.B. Ushakov ed. Moscow, Meditsina Publ., 2007, 104 p. (in Russian).

4. Theorell T., Perski A., Akerstedt T., Sigala F., Ahlberg-Hultén G., Svensson J., Eneroth P. Changes in job strain in relation to changes in physiological state. Scand. J. Work Environ. Health, 2013, vol. 14, no. 3, pp. 189-196. DOI: 10.5271/sjweh.1932

5. Anishchenko V.S., Kislitsyn Yu.L., Permyakov I.A. Monitoring rezervov fizicheskoi rabotosposobnosti zdorov'ya studentov [Monitoring over reserves of students' health and its physical working capacity]. Uspekhi i perspektivy fiziologii truda v tret'em tysyacheletii: materialy konferentsii. Moscow, 2001, pp. 25-27 (in Russian).

6. Kosorotova N.S., Reshetenko I.N., Bulavina M.V. Otsenka rabotosposobnosti u rabotnikov, zanyatykh tyazhelym fizicheskim trudom. Professional'noe zdorov'e i trudovoe dolgoletie: materialy Mezhdunarodnoi nauchno-prakticheskoi konferentsii. Shakhty, 2018, pp. 94-95 (in Russian).

7. Abol'yan L.V. Znachenie urovnya obshchei fizicheskoi rabotosposobnosti v razvitii utomleniya rabotayushchikh v usloviyakh professional'noi gipokinezii [Importance of overall physical working capacity and developing fatigue among workers under exposure to occupational hypokinesia]. Gigiena truda i professional'nye zabolevaniya, 1982, no. 10, pp. 14-18 (in Russian).

8. Matyukhin V.V., Bukhtiyarov I.V., Yushkova O.I., Shardakova E.F., Yampol'skaya E.G., Elizarova V.V., Poroshenko A.S., Kapustina A.V. [et al.]. Labor physiology role in workers of different type 
labor activity workability and health. Progress and prospects. Meditsina truda i promyshlennaya ekologiya, 2013, no. 6, pp. 19-24 (in Russian).

9. Yampol'skaya E.G., Shardakova E.F., Elizarova V.V. Izuchenie vzaimosvyazi urovnya obshchei fizicheskoi rabotosposobnosti i pokazatelei zabolevaemosti [Examining a correlation between overall physical working capacity and morbidity]. Psikhofiziologicheskie aspekty trudovoi deyatel'nosti: vserossiiskii sbornik nauchnykh statei. Tver', 2002, pp. 43-49 (in Russian).

10. Matyukhin V.V., Elizarova V.V., Shardakova E.F., Yampol'skaya E.G. Risk factors of functional disorders in mental workers. Meditsina truda i promyshlennaya ekologiya, 2009, no. 6, pp. 1-6 (in Russian).

11. Shardakova E.F., Yushkova O.I., Elizarova V.V., Lagutina G.N. Physiological evaluation of physical and nervous-mental overloads in medicine of labor. Vestnik Tverskogo Gosudarstvennogo Universiteta. Seriya: Biologiya i ekologiya, 2018, no. 3, pp. 7-20 (in Russian).

12. Danilov A.N., Bezrukova G.A., Novikova T.A. Work hardiness as a determinant of occupational health risk in agricultural workers. Meditsina truda i promyshlennaya ekologiya, 2017, no. 9, pp. 59 (in Russian).

13. Merkulova A.G., Kalinina S.A., Bogdanova V.E. Dynamic study of the nervous muscular system of machine operator at the engine make. Meditsina truda i promyshlennaya ekologiya, 2019, vol. 59, no. 9, pp. 695-696 (in Russian).

14. Punnett L., Prüss-Utün A., Imel Nelson D., Fingerhut M.A., Leigh J., Tak S.W., Phillips S. Estimating the global burden of low back pain attributable to combined occupational exposures. Am. J. Ind. Med., 2005, vol. 48, pp. 459-469. DOI: 10.1002/ajim.20232

15. Bruce P., Bernard M.D. Musculoskeletal disorders and workplace factors: A critical review of epidemiologic evidence for work-related musculoskeletal disorders of the neck, upper extremity and low back. U.S.A.: U.S. Department of health and human services Public Health Service Centers for Disease Control and Prevention National Institute for Occupational Safety and Health Publ., 1997, 590 p.

16. Ariëns G.A., Van Mechelen W., Bongers P.M., Bouter L.M., Van der Wal G. Physical risk factors for neck pain. Scandinavian Journal of Work, Environment \& Health, 2000, vol. 26, no. 1, pp. 17-19. DOI: 10.5271/sjweh.504

17. Musculoskeletal disorders and the workplace: Low Back and Upper Extremities. National Research Council and the Institute of Medicine. Washington, 2001, pp. 492. DOI: 10.17226/10032

18. Haakkanen M., Viikari-Juntura E., Martikainen R. Incidence of muscular-sceletal disorders among newly employed manufacturing workers. Scand. J. Work Environ Health, 2001, vol. 27, no. 6, pp. 381-387. DOI: $10.5271 /$ sjweh.630

19. Heliovaara M. Work load and back pain. Scand. J. Work Environ Health, 1999, vol. 25, no. 5, pp. 385-386. DOI: $10.5271 /$ sjweh.450

20. Maksimenko L.V., Yakovenko I.A. Backache risk in dentistry workers. Meditsina truda i promyshlennaya ekologiya, 2017, no. 9, pp. 118 (in Russian).

21. Khodzhiev M., Shardakova E.F., Elizarova V.V. Assessing functional state of labor migrants engaged into construction works. Meditsina truda i promyshlennaya ekologiya, 2017, no. 9, pp. 207 (in Russian).

22. Prokopenko L.V., Shardakova E.F., Yampol'skaya E.G., Elizarova V.V., Lagutina A.V. Integrated physiological-hygienic evaluation of labor in leading professional groups under modern technologies of constructing activities. Vestnik Tverskogo Gosudarstvennogo Universiteta. Seriya: Biologiya i ekologiya, 2014, no. 1, pp. 65-74 (in Russian).

23. Khodzhiev M. Cardiovascular features and adaptable opportunities of the first course university students organism. Vestnik Tverskogo Gosudarstvennogo Universiteta. Seriya: Biologiya i ekologiya, 2016 , no. 3, pp. 18-27 (in Russian).

24. Tsfasman A.Z., Alpaev D.V. Tsirkadnaya ritmika arterial'nogo davleniya pri izmenennom sutochnom ritme zhizni [Circadian rhythms of blood pressure in case daily rhythms have been changed]. Moscow, Reprotsentr Publ., 2011, 144 p. (in Russian).

Bukhtiyarov I.V., Yushkova O.I., Khodzhiev M., Kapustina A.V., Forverts A.Yu. Physiological criteria for improving labor intensity classification used in occupational risks assessment. Health Risk Analysis, 2021, no. 1, pp. 90-99. DOI: 10.21668/health.risk/2021.1.09.eng

Received: 18.01.2021

Accepted: 07.02.2021

Published: 30.03.2021 
UDC $616.12(008.331)$

DOI: 10.21668/health.risk/2021.1.10.eng

Research article

\section{HYPERTENSION AMONG COAL MINING WORKERS ASSOCIATED WITH PARENTAL HYPERTENSION IN INDONESIA}

\section{Kurnia Ardiansyah Akbar}

Faculty of Public Health, Jember University, Jl. Kalimantan No. 42, Krajan Timur, Sumbersari, Kec. Sumbersari, Jember Regency, East Java, 68121, Indonesia

Hypertension is a chronic disease with its prevalence increasing from 2013 to 2018 among population in Indonesia. In 2013 the prevalence of hypertension was 25.8\%, and in 2018 it increased to $34.1 \%$. Therefore, to control hypertension, it is necessary to involve all related parties, doctors and health professionals from various fields of hypertension specialization, government, the private sector, and the public.

Business is a private party that has the authority to participate in the prevention of hypertension in Indonesia. Coal mining sector traditionally creates a lot of workplaces in the country. This study aimed to look at the influence exerted by hypertension in parents' case history on risks of incidence with hypertension among coal mining workers.

This study is a cross-sectional one with two variables, namely hypertension in parents' case histories and hypertension among coal mining workers performed on a sampling including 360 coal mining workers. The results showed that if a father had hypertension in his case history the risk of incidence with hypertension among coal mining workers was 3.143 times higher because OR $=3.143 ; 95 \%$ CI $(1.568<$ OR $<6.229)$, while if a mother had hypertension in her case history the risk of incidence with hypertension among coal mining workers was 6.519 times higher because OR $=6.519 ; 95 \%$ CI $(3,267<O R<13,008)$ and if both parents have hypertension in their case history, the risk of incidence with hypertension among coal mine workers was 6.061 times higher because $\mathrm{OR}=6.061 ; 95 \% \mathrm{CI}(2,910<\mathrm{OR}<12,625)$. The obtained results are enough to prove that hereditary or genetic factors play their role in elevated risks of hypertension in coal mining workers.

Key words: workers, coal mining, coal mining workers, hypertension, risks of hypertension, parental hypertension, hypertension in workers, hypertension in coal mining workers, hypertension in Indonesia.

Hypertension is a chronic disease that becomes apparent via an increase in systolic blood pressure when it exceeds $140 \mathrm{mmHg}$ and diastolic blood pressure being more than $90 \mathrm{mmHg}$ if two measurements are taken in five-minute intervals in a state of sufficient rest and calm [1-3]. As per data obtained by Riskesdas in 2018, hypertension prevalence among Indonesia's population grew from 2013 to 2018. The highest hypertension prevalence was detected in the South Kalimantan $(44.1 \%)$, and the lowest, in Papua $(22.2 \%)$. Hypertension occurs among people aged 31-44 (31.6\%), 45-54 (45.3\%), and 55-64 (55.2\%). In 2013 the prevalence of hypertension was $25.8 \%$, and in 2018 it increased to $34.1 \%$ [4]. Increased blood pressure over a long period can damage the kidneys, brain (causing stroke), and the heart if the hypertension event is not detected early and not properly treated. The number of hypertensive patients with uncontrolled blood pressure is increasing continuously $[5,6]$.

Therefore, the participation of all related parties, both medical doctors from various fields of specialization in hypertension, government, private sector, and society, is needed to control hypertension [7].

One of the private parties that should participate in the prevention of hypertension in Indonesia is business. Coal mining is a sector in economy with a large workforce and growing up every year. Coal mining is laborintensive and capital-intensive economic activity in Indonesia [8]. A coal company's distinctive feature is the number of dwellings in a mining area for workers or what is commonly called a mess. The mess is equipped with all

(C) Akbar Ardiansyah Kurnia, 2021

Akbar Ardiansyah Kurnia - Master of Occupational Health and Safety, Assistant Professor at Faculty of Public Health (e-mail: ardiansyah_akbar@unej.ac.id; tel.: +62-85746757111; ORCID: http://orcid.org/0000-0001-6265-3064). 
adequate facilities starting from a residence, cafeteria, sports venue, places of worship, etc. All adequate facilities were built because most workers have to live in a mining area for $2-5$ weeks before they get a day off $[9,10]$.

The mining work system, which requires employees to live in a mining mess, results in all worker activities being carried out in one area, including work, rest, eating, and sports. The risk of workers experiencing hypertension will occur if their lifestyle, including work patterns, rest, eating, and exercise, is not healthy. It will even be exacerbated in case workers' parents have hypertension in their case history. Research on general population groups in Sri Lanka shows that the prevalence of hypertension increases to $29.3 \%$ if parents have the disease in their case history [11].

This research goal was to examine influence exerted by hypertension in parents' case history on risks of incidence with hypertension among coal mining workers.

Data and methods. This study was a cross-sectional one with two variables, namely hypertension in parents' case history and hypertension among coal mining workers. The data used are primary data obtained via conducting interviews with questionnaires and measuring respondents' blood pressure. Data on hypertension in parents' case history were obtained using a questionnaire filled in by respondents, and data on hypertension among coal mining workers were obtained via direct measuring respondents' blood pressure using a calibrated mercury sphygmomanometer. Hypertension examination was carried out on a respondent's arm by professional physical therapists at a local health clinic [12].

The hypertension measurement results were then classified based on the hypertension classification, referring to JNC VII $2003[12,13]$.

Blood pressure examination is included into a General Medical Check-Up in the framework of annual/periodic health checks on workers following the Regulation of the Minister of Manpower and Transmigration of the Republic of Indonesia No. Per.02 / MEN / 1980 concerning workforce health checks stipulated in the implementation of work safety.
Table 1

Classification of Blood Pressure for Adults

\begin{tabular}{|l|c|c|c|}
\hline \multicolumn{1}{|c|}{ Category } & $\begin{array}{c}\text { Systolic } / \\
\text { SBP } \\
(\mathrm{mmHg})\end{array}$ & & $\begin{array}{c}\text { Diastolic } / \\
\text { DBP } \\
(\mathrm{mmHg})\end{array}$ \\
\hline Normal & $<120$ & And & $<80$ \\
\hline Prehypertention & $120-139$ & Or & $80-89$ \\
\hline Hypertention & & & \\
\hline Stage 1 & $140-159$ & Or & $90-99$ \\
\hline Stage 2 & $>160$ & Or & $>100$ \\
\hline
\end{tabular}

N o t e : Adapted From JNC VII, 2003.

In this study, respondents were coal mine workers in Kalimantan, Indonesia, with a sample size of 360 coal mine workers. The respondents' characteristics included the following: they were all males, their working experience was longer than one year, and they were all working at a mining site. These criteria aim to control for research bias.

Respondents were selected using a sampling technique, namely cluster random sampling. The data were processed by bivariate analysis using a non-parametric test.

Results and discussion. The obtained results are shown in Tables 2-4.

Table 2 shows that 40 respondents out of 360 coal mining workers had hypertension when they were examined and 320 didn't have it. Based on questioning, we detected that 72 people's fathers had hypertension in their case history, while fathers of 288 others did not.

Based on data given in Table 2 we can conclude that there is a relationship between paternal hypertension and coal mining worker hypertension with a p-value of $0.001<\alpha=0.05$. The risk of incidence with hypertension among coal mining workers if a father has a history of hypertension is 3.143 times higher because $\mathrm{OR}=3.143 ; 95 \% \mathrm{CI}(1.568<\mathrm{OR}<6.229)$.

Table 3 shows that 320 respondents out of 360 coal mining workers, did not have hypertension when being checked, while 40 respondents had hypertension when they were examined. Based on questioning, we detected that 78 people's mothers had hypertension in their case history, while mothers of 282 others did not have it. 
Table 2

Hypertension in father's case history influencing risk of hypertension among coal mining worker

\begin{tabular}{|c|c|c|c|c|c|c|}
\hline & \multicolumn{2}{|c|}{ Father's case history } & \multirow{2}{*}{ Total } & \multirow{2}{*}{ p-value } & \multirow{2}{*}{ OR } \\
\hline & & Not-Hypertension & Hypertension & & & \\
\hline \multirow{2}{*}{$\begin{array}{l}\text { Coal mining workers } \\
\text { Hypertension }\end{array}$} & Not-Hypertension & 264 & 56 & 320 & \multirow{2}{*}{0.001} & \multirow{2}{*}{3.143} \\
\hline & Hypertension & 24 & 16 & 40 & & \\
\hline \multicolumn{2}{|l|}{ Total } & 288 & 72 & 360 & & \\
\hline
\end{tabular}

Source: Primary Data.

Table 3

Hypertension in mother's case history influencing risk of hypertension among coal mining worker

\begin{tabular}{|c|c|c|c|c|c|c|}
\hline & \multicolumn{2}{|c|}{ Mother's case history } & \multirow{2}{*}{ Total } & \multirow{2}{*}{$\mathrm{p}$-value } & \multirow{2}{*}{ OR } \\
\hline & & Not-Hypertension & Hypertension & & & \\
\hline \multirow{2}{*}{$\begin{array}{l}\text { Coal mining workers } \\
\text { Hypertension }\end{array}$} & Not-Hypertension & 265 & 55 & 320 & \multirow[b]{2}{*}{0.000} & \multirow[b]{2}{*}{6.519} \\
\hline & Hypertension & 17 & 23 & 40 & & \\
\hline \multicolumn{2}{|l|}{ Total } & 282 & 78 & 360 & & \\
\hline
\end{tabular}

Source: Primary Data.

Table 4

Hypertension in parents' case history influencing risk of hypertension among coal mining worker

\begin{tabular}{|c|c|c|c|c|c|c|}
\hline & \multicolumn{2}{|c|}{ Parents' case history } & \multirow{2}{*}{ Total } & \multirow{2}{*}{ p-value } & \multirow{2}{*}{ OR } \\
\hline & & Not-Hypertension & Hypertension & & & \\
\hline \multirow{2}{*}{$\begin{array}{l}\text { Coal mining workers } \\
\text { Hypertension }\end{array}$} & Not-Hypertension & 223 & 97 & 320 & \multirow[b]{2}{*}{0.000} & \multirow[b]{2}{*}{6.061} \\
\hline & Hypertension & 11 & 29 & 40 & & \\
\hline \multicolumn{2}{|l|}{ Total } & 234 & 126 & 360 & & \\
\hline
\end{tabular}

Source: Primary Data.

Based on data given in Table 3 we can conclude that there is a relationship between a mother having hypertension in her case history and hypertension in a coal mining worker with a p-value of $0.000<\alpha=0.05$. The risk of incidence with hypertension among coal mining workers if a mother has a history of hypertension is 6,519 times higher because $\mathrm{OR}=6,519$; $95 \%$ CI $(3.267<$ OR $<13.008)$.

Table 4 shows that 320 respondents out of 360 coal mining workers, did not have hypertension when being checked, while 40 respondents had hypertension when they were examined. Based on questioning, we detected there were 126 people whose parent, either mother or father, or both of them, had hypertension in his or her (or their) case history whereas parents of the remaining 234 workers did not have it.

Based on data given in Table 4 we can conclude that there is a relationship between hypertension in parents' case history and hyper- tension among coal mining workers with a $\mathrm{p}$ value of $0.000<\alpha=0.05$. The risk of incidence with hypertension among coal mining workers if parents have a history of hypertension is 6,061 higher times because OR $=6,061 ; 95 \%$ CI $(2,910<\mathrm{OR}<12,625)$.

Based on the results obtained via the above research, three main points can be discussed, including influence exerted by paternal hypertension on risk of incidence with hypertension among coal mining workers, by hypertension in father's case history, and hypertension in mothers' case histories as well.

This study shows that the number of hypertension cases is higher among elderly (126 people) than among coal mining workers (40 people), mining workers aged from 18 years to 56 years. This study is in line with previous studies, stating that parents have a high incidence rate of hypertension, especially at the age exceeding 60 years, with a prevalence rate 
being from $60 \%$ to $80 \%[14,15]$. In another study performed in Sao Paulo, it was found that prevalence of hypertension among elderly groups was $70 \%$ of the total population [16]. Research in China also shows that hypertension is found in $53 \%$ of the elderly population [17].

The results showed a relationship between hypertension in a father's, mother's (and parents') case history and incidence with hypertension among coal mining workers. The relationship between hypertension in a father's and mother's case history shows that genetic hypertension can be inherited from either father or mother or even from both parents. According to research that has been done if both parents suffer from hypertension, about $45 \%$ will be passed down to the offspring, and if one parent is suffering from hypertension, about $30 \%$ will be passed down to the offspring $[18,19]$.

In this study, the odds ratio (OR) value for each relationship between variables was obtained. OR $=3.143$ obtained for hypertension in a father's case history shows that if a father has hypertension in his case history, risk of incidence with hypertension among coal mine workers is 3.143 times higher. OR obtained for hypertension in a mother's case history is equal to 6.519 . This means that if a mother hypertensionin her case history, the risk of hypertension among coal mining workers is 6.519 times higher. OR obtained for hypertension in parents' case histories is equal to 6.016. It means that if parents have hypertension in their case history, the risk of hypertension among coal mining workers is 6.061 times higher.

The above research follows the results obtained in previous studies. This study aims to determine the prevalence of hypertension and the determinants of hypertension among elderly people. This research is a quantitative study with a cross-sectional study design in the elderly group. Based on the study results, it was found that a hypertension in family case history is a risk factor causing occurrence of hypertension. The risk of developing hypertension for someone who has hypertension in family case histories is 3.216 times higher than for those whose parents do not have hypertension in their case history [20].

Previous research states that someone whose parents have hypertension in their case history runs higher risk of suffering from hypertension. This possibility occurs because someone whose parents suffer from hypertension, will inherit genes that interact with the environment and cause an increase in blood pressure. Genetic factors result in risks of developing hypertension, as evidenced by a phenomenon that hypertension is more common in monozygous twins (one egg) than in heterozygous (different egg cells). If someone who has a genetic trait of primary (essential) hypertension is then left without therapeutic intervention early on, then exposure to environmental factors will cause hypertension to develop, and at an age of 30-50 years, signs and symptoms will appear [21, 22].

The risk of hypertension, which is related to parental genetics based on previous analysis, is exacerbated by working conditions existing at coal mines. This study focuses on the risk of hypertension among coal mining workers due to exposure to the working environment they have to face at their workplaces and the unhealthy behavior patterns they tend to pursue.

The working environment at coal mines in Indonesia creates occupational risks for workers via physical environmental hazards, namely heat and noise, chemical, environmental hazards, namely coal dust, and psychological dangers. Influence exerted by environmental hazard risks plays a significant role in high prevalence of hypertension among mining workers in Indonesia.

Coal mining environment in Indonesia tends to be dry and hot because it is located along the equator and in tropical climate areas, resulting in increased heat exposure for workers. Heat exposure received by workers is direct exposure to sunlight because Indonesian coal mines are open-pit ones.

Workers are exposed to heat from the sun throughout the year while doing their work. The average temperature in mining areas in Indonesian Kalimantan throughout the year is 
$27.6^{\circ} \mathrm{C}$ or $81.68^{\circ} \mathrm{F}$, with the lowest recorded temperature being $19.1{ }^{\circ} \mathrm{C}$ or $66.38^{\circ} \mathrm{F}$, and the highest temperature is $38^{\circ} \mathrm{C}$ or $100.4^{\circ} \mathrm{F}$ [23]. The temperature distribution indicates that the risk of heat exposure received by coal mining workers is very high compared to normal work climate accepted by general humans.

Exposure to heat while working increases the risk of hypertension for coal mine workers. Exposure to heat while working affects body's internal temperature, which then gradually affects the cardiovascular system. Worker's body exposed to heat automatically tries to adapt to temperatures existing in a working environment by increasing blood flow to the heatexposed skin to control body temperature. This increased blood flow to the skin is accomplished via increased blood flow from the heart. The mechanism of increasing the pump for blood flow from the heart causes the detected blood pressure to increase when measurements are taken.

These results are consistent with previous experimental laboratory studies performed on mice revealing that heat exposure will increase mice's systolic and diastolic blood pressure. Increased blood pressure was detected starting at the moment when mice were exposed to $27^{\circ} \mathrm{C}$ or $80.6^{\circ} \mathrm{F}$ and above [24].

Continuous heat exposure causes a worker's body to adapt significantly. Adaptation in miners' bodies is accomplished via the cardiovascular system that always works above standard, and it can cause hypertension in coal mining workers in Indonesia.

The high risk of hypertension due to heat exposure can be remedied with well-planned prevention. One of them is implementing restrictions on working hours when the ambient temperature is recorded to exceed $27^{\circ} \mathrm{C}$ or $80.6^{\circ} \mathrm{F}$. This temperature becomes a limit because research shows that an increase in blood pressure occurs at that temperature. Limitation imposed on working hours aims to reduce heat exposure experienced by coal mine workers, especially in summer.

Exposure to noise hazards also exacerbates the risk of developing hypertension in coal mining workers in Indonesia. Noise in coal mining comes from heavy equipment, conveyors, subsoil blasting, and coal dredging. Mining workers are exposed to noise during a working shift which is equal to eight hours in Indonesia.

Based on CDC data, it is known that coal mine workers are exposed to noise hazards above $90 \mathrm{dBA}$ at their workplaces [25]. In Indonesia, the noise limit at a workplace for a 8-hour work shift has been stipulated in the Regulation of the Minister of Manpower of the Republic of Indonesia Number 5 of 2018 concerning Occupational Safety and Health. According to it noise in a work environment should not exceed $85 \mathrm{dBA}$, and the maximum allowable limit is $139 \mathrm{dBA}$ with an exposure time not exceeding 0.11 seconds. Based on the regulation, noise in coal mines is a risk factor that must be controlled.

The impact exerted by noise on incidence with hypertension is classified as non-auditory impacts. Exposure to noise exacerbates a possibility of hypertension among coal mine workers. When exposed to noise, mine workers feel disturbed. These feelings lead to anxiety and stress among them. The stress causes cardiovascular changes in workers, one of which is an increase in blood pressure. Prolonged noise exposure will result in a necessity for a body to recover. This recovery includes elimination of non-auditory noise impacts. Stress caused by noise can become chronic. Chronic stress that causes an increase in blood pressure continues with the final manifestation of hypertension in coal mining workers.

Noise increases the risk of hypertension among workers in line with existing research. Previous research has shown that noise will have an impact on prolonged stress. This stress is then followed by an increase in blood lipids, blood viscosity, blood pressure, cardiac output, blood glucose, and blood clotting factors, which result in cardiovascular diseases, including stroke, ischemic heart disease, and arterial hypertension [26].

As for coal mine workers and their exposure to noise, the risk of hypertension can be reduced using personal protective equipment, especially those aimed at reducing noise expo- 
sure, both earplugs, and earmuffs when working under exposure to noise. Several earplugs and ear muffs in Indonesia can reduce noise received by workers by 10-20 dBA.

We also studied a relationship between hypertension among coal mine workers and exposure to dust. The high rate of hypertension in the study can also be caused by exposure to dust at a workplace. It has been explained previously that the environment at coal mines in Indonesia is dry, especially during hot or dry season, which results in dry soil conditions and causes much dust in summer or dry season. Dust that is a risk factor for coal mining workers comes from dry ground dust from coal being processed during mining activities.

Exposure to dust that enters through the respiratory tracts causes an increased risk of hypertension among coal mining workers due to dust being carried through the respiratory tracts and then to the lungs. The microscopic dust particles will continue to be carried around as blood circulation occurs from the lungs to the heart. The coarse particles then partially block blood flow to the heart. This inhibition of blood flow to the heart causes an increase in blood pressure, leading to hypertension in coal mining workers.

Experimental studies on humans related to dust also explain that humans exposed to dust particles with their diameter being 2.5-10 micrometers suffer from an increase in heart rate and systolic and diastolic blood pressure. This happens due to coarse particles carried by the bloodstream causing disruption of blood circu- lation to the heart $[27,28]$. Preventing increased risks of hypertension due to dust exposure can require workers to wear masks while working. A mask in question is a dust mask with the ability to filter dust up to particles with their diameter being 2.5 micrometers so that they cannot enter the respiratory tract. If coal mine workers use these masks, it is recommended to change cartridges in them periodically.

This discussion shows that examined coal mining environment creates an enormous risk of increased hypertension prevalence. A specific work system existing at Indonesian coal mines involves mining workers spending their nights in a cottage for several weeks, causing a possibility of even a higher risk of hypertension among them. This can possibly be due to work stress, a psychological burden of not meeting family, a poor diet, and exercise.

Conclusion. Based on the results of the study, we can conclude that there is a relationship between hypertension in parents' case history and incidence with hypertension among coal mining workers. This is sufficient to prove that heredity or genetics plays a role in increasing risks of hypertension among coal mining workers. Coal mining environment creates an enormous risk of increasing hypertension prevalence among coal mining workers.

Funding. The research was not granted any financial support.

Conflict of interests. The authors declare there is no any conflict of interests.

\section{References}

1. Nerenberg K.A., Zarnke K.B., Leung A.A., Dasgupta K., Butalia S., McBrien K., Harris K.C., Nakhla M. [et al.]. Hypertension Canada's 2018 Guidelines for Diagnosis, Risk Assessment, Prevention, and Treatment of Hypertension in Adults and Children. Can. J. Cardiol., 2018, vol. 34, no. 5, pp. 506-525. DOI: $10.1016 /$ j.cjca.2018.02.022

2. Pickering G. Hypertension. Definitions, natural histories and consequences. Am. J. Med., 1972, vol. 52, no. 5, pp. 570-583. DOI: 10.1016/0002-9343(72)90049-6

3. Kitaoka M., Mitoma J., Asakura H., Anyenda O.E., Nguyen T.T.T., Hamagishi T., Hori D., Suzuki F. [et al.]. The relationship between hypertension and health-related quality of life: adjusted by chronic pain, chronic diseases, and life habits in the general middle-aged population in Japan. Environ Health. Prev. Med., 2016, vol. 21, no. 4, pp. 193-214. DOI: 10.1007/s12199-016-0514-6

4. Hipertensi Penyakit Paling Banyak Diidap Masyarakat. Kementerian Kesehatan Republik Indonesia, 2018. Available at: https://www.kemkes.go.id/article/view/19051700002/hipertensi-penyakitpaling-banyak-diidap-masyarakat.html (03.08.2020). 
5. J. Sundström, H. Arima, R. Jackson, F. Turnbull, K. Rahimi, J. Chalmers, M. Woodward, B. Neal [et al.]. Effects of blood pressure reduction in mild hypertension: A systematic review and meta-analysis. Ann. Intern. Med., 2015, vol. 162, no. 3, pp. 184-191. DOI: 10.7326/M14-0773

6. Zhou D., Xi B., Zhao M., Wang L., Veeranki S.P. Uncontrolled hypertension increases risk of all-cause and cardiovascular disease mortality in US adults: The NHANES III Linked Mortality Study. Sci. Rep., 2018, vol. 20, no. 8 (1), pp. 9418. DOI: 10.1038/s41598-018-27377-2

7. Hipertensi. Pusat Data dan lnformasi Kementerian Kesehatan RI, 2018, 8 p.

8. Tambunan T. Recent evidence of the development of micro, small and medium enterprises in Indonesia. J. Glob. Entrep. Res., 2019, no. 9, pp. 18. DOI: 10.1186/s40497-018-0140-4

9. Shi X., Song Z. The Silent Majority: Local residents' environmental behavior and its influencing factors in coal mine area. J. Clean. Prod., 2019, no. 240, pp. 118275. DOI: 10.1016/j.jclepro.2019.118275

10. Bhattacherjee A., Kunar B. Miners' return to work following injuries in coal mines. Med. Pr., 2016, vol. 67, no. 6, pp. 729-742. DOI: 10.13075/mp.5893.00429

11. Ranasinghe P., Cooray D.N., Jayawardena R., Katulanda P. The influence of family history of Hypertension on disease prevalence and associated metabolic risk factors among Sri Lankan adults Chronic Disease epidemiology. BMC Public. Health, 2015, vol. 20, no. 15, pp. 576. DOI: 10.1186/s12889-015-1927-7

12. Frese E.M., Fick A., Sadowsky S.H. Blood Pressure Measurement Guidelines for Physical Therapists. Cardiopulm Phys. Ther. J., 2011, vol. 22, no. 2, pp. 5-12.

13. The Seventh Report of the Joint National Committee on Prevention, Detection, Evaluation, and Treatment of High Blood Pressure (JNC 7). U.S. department of health and human services; National Institutes of Health National Heart, Lung, and Blood Institute, 2003, pp. 104.

14. Chataut J., Khanal K., Manandhar K. Prevalence and associated factors of hypertension among adults in rural Nepal: A community based study. Kathmandu Univ. Med. J., 2016, vol. 13, no. 4, pp. 346-350. DOI: 10.3126/kumj.v13i4.16835

15. Egan B.M. Defining hypertension by blood pressure $130 / 80 \mathrm{~mm} \mathrm{Hg}$ leads to an impressive burden of hypertension in young and middle-aged black adults: Follow-up in the CARDIA study. J. Am. Heart. Assoc., 2018, vol. 17, no. 7 (14), pp. e009971. DOI: 10.1161/JAHA.118.009971

16. Buford T.W. Hypertension and aging. Ageing Res. Rev., 2016, vol. 26, no. 1, pp. 96-111. DOI: 10.1016/j.arr.2016.01.007

17. Lacerda J., Lopes M.R., Ferreira D.P., Fonseca F.L.A., Favaro P. Descriptive study of the prevalence of anemia, hypertension, diabetes and quality of life in a randomly selected population of elderly subjects from São Paulo. Rev. Bras. Hematol. Hemoter., 2016, vol. 38, no. 2, pp. 96-111. DOI: 10.1016/j.arr.2016.01.007

18. Liu M., He Y., Jiang B., Wang J., Wu L., Wang Y., Zhang D., Zeng J., Yao Y. Association between family history and hypertension among Chinese elderly. Med. (United States)., 2015, vol. 94, no. 48, pp. e2226. DOI: 10.1097/MD.0000000000002226

19. Yoo J.E., Park H.S. Relationship between parental hypertension and cardiometabolic risk factors in adolescents. J. Clin. Hypertens, 2017, vol. 19, no. 7, pp. 678-683. DOI: 10.1111/jch.12991

20. Chen H., Sun M., Fan Z., Wu X., Li J., Zhu Y., Zhu J. Fathers may play a bigger role than mothers in hypertensive patients complicated with coronary heart disease. Biomed Res., 2018, vol. 29, no. 3, pp. 558-562. DOI: 10.4066/biomedicalresearch.29-17-3230

21. Sun D., Liu J., Xiao L., Liu Y., Wang Z., Li C., Jin Y., Zhao Q., We S. Recent development of risk-prediction models for incident hypertension: An updated systematic review. PLoS One, 2017, vol. 12, no. 10, pp. e0187240. DOI: 10.1371/journal.pone.0187240

22. Ahn S.Y., Gupta C. Genetic programming of hypertension. Front Pediatr, 2018, vol. 22, no. 5, pp. 285. DOI: $10.3389 /$ fped.2017.00285

23. Suhu Minimum, Rata-Rata, dan Maksimum di Stasiun Pengamatan BMKG. Badan Pusat Statistik, 2017. Available at: https://www.bps.go.id/statictable/2017/02/09/1961/suhu-minimum-rata-ratadan-maksimum-di-stasiun-pengamatan-bmkg-oc-2011-2015.html (03.08.2020).

24. Swali A. The impact of heat stress on blood pressure. Heat Stress. Causes, Treatment and Prevention, 2012, no. 19, pp. 3809-3819.

25. Babich D.R., Bauer E.R., Vipperman J.R. Equipment Noise and Worker Exposure in the Coal Mining Industry. United States Natl Inst Occup Saf Heal (NIOSH), 2006, no. 2006, pp. 1-77. 
26. Münzel T., Sørensen M. Noise pollution and arterial hypertension. Eur. Cardiol. Rev., 2017, vol. 12, no. 1, pp. 26-29. DOI: 10.15420/ecr.2016:31:2

27. Byrd J.B., Morishita M., Bard R.L., Das R., Wang L., Sun Z., Spino C., Harkema J. [et al.]. Acute increase in blood pressure during inhalation of coarse particulate matter air pollution from an urban location. J. Am. Soc. Hypertens., 2016, vol. 10, no. 2, pp. 133-139. DOI: 10.1016/j.jash.2015.11.015

28. Pearson J.F., Bachireddy C., Shyamprasad S., Goldfine A.B., Brownstein J.S. Association between fine particulate matter and diabetes prevalence in the U.S. Diabetes Care. Diabetes Care, 2010, vol. 33, no. 10, pp. 2196-2201. DOI: 10.2337/dc10-0698

Kurnia Ardiansyah Akbar. Hypertension among coal mining workers associated with parental hypertension in Indonesia. Health Risk Analysis, 2021, no. 1, pp. 100-107. DOI: 10.21668/health.risk/2020.1.10.eng

Received: 19.08 .2020

Accepted: 03.03.2021

Published: 30.03 .2021 
UDC 619:616.98: 579.852.1

DOI: $10.21668 /$ health.risk/2021.1.11.eng

Research article

\title{
ANTHRAX CATTLE BURIALS AS A POTENTIAL THREAT CAUSED BY CHANGES IN CRYOLITE ZONES IN THE NORTHERN EUROPEAN PART OF RUSSIA
}

\author{
S.A. Iglovsky, V.V. Kriauciunas \\ N. Laverov Federal Center for Integrated Arctic Research of the Ural Branch of the Russian Academy of Sciences, \\ 109 Naberezhnaya Severnoi Dviny, Arkhangel'sk, 163000, Russian Federation
}

Over recent years there have been registered anthrax cases among animals and people in Russia. Anthrax cattle burials remain a basic risk factor that causes epizootic deterioration. A lot of such burials do not correspond to sanitaryepidemiologic requirements especially those located in zones where long-term frozen rocks are now being developed in the northern European part of the country.

Our research goal was to examine a situation with anthrax cattle burials in the chosen regions, especially bearing in mind climatic changes and changes in cryolite zones as well as to assess future prospects regarding them. It is especially vital for native people who live in tundra and breed their numerous deer herds there.

To achieve the goal, several tasks were accomplished. First, we performed preliminary analysis of anthrax cattle burials distribution in the northern European part of the country and places that were unfavorable as per anthrax. Then, locations of such zones were compared with available data on contemporary development of the cryolite zone in the northern European part of the country. It was necessary to assess future changes in the cryolite zone and describe occurring problems related to anthrax cattle burials being widely spread there as well as to suggest possible ways to solve them. Over the last 50 years considerable spots in the cryolite zone have thawed through completely or partially, especially in an area close to the south border of frozen earth. It is important to know an actual situation with anthrax cattle burials given changing climatic conditions and to assess their future prospects. In order to prevent emergencies in zones where geocryological processes have been activated it is necessary to measure temperature on anthrax cattle burials territories, to assess geocryological threats, to create mathematical models for probable negative events occurrence, as well as to accomplish certain anti-epidemic, anti-epizootic, and preventive activities.

Key words: anthrax cattle burials, risks, cryolite zone, seasonal-thawed layer, frozen earth degradation, thawing through, monitoring.

Recently there have been anthrax cases among people and animals registered in Russia. The disease was caused by contacts with infected animals being slaughtered without giving notice to veterinary services; by people treating animals' carcasses or burying corpses of animals that died due to anthrax; by people working with infected meat, treating sick ani- mals, or selling raw meat on markets. Anthrax cattle burials remain a risk factor that might cause epizootic ill-being related to anthrax since many of them do not conform to sanitary-epidemiologic requirements as it was mentioned in the works [1-12], especially in permafrost zones and zones prone to seasonal freezing ${ }^{1}$. These cattle burials can be destroyed

(C) Iglovsky S.A., Kriauciunas V.V., 2021

Stanislav A. Iglovsky - Candidate of Geographical Sciences, Leading researcher (e-mail: iglovskys@mail.ru; tel.: +7 (921) 240-80-08; ORCID: https://orcid.org/0000-0001-9675-455X).

Vidas V. Kriauciunas - Candidate of Geological and Mineralogical Sciences, Leading researcher (e-mail: vidas76@mail.ru; tel.: +7 (911) 068-15-76; ORCID: https://orcid.org/0000-0001-7437-381X).

${ }^{1}$ Osadchaya G.G., Tumel'N.V., Zengina T. Yu., Lapteva E.M. Survey geocryological map of Bolshezemelskaya tundra (Komi Republic and the Nenets Autonomous Area). Scaled 1:1,000,000. The project report issued within PROON/GEF/ES project Strengthening the system of natural protected areas in Komi Republic aimed at preserving biological diversity in primary forests located near the upper Pechora. Syktyvkar, Publishing house of the Komi SC of the RAS Urals Branch Publ., 2015, 112 p. (in Russian). 
due to permafrost thawing. In 2016 in the RF epidemiologic satiation with anthrax deteriorated. There was an anthrax focus registered in Yamal distirct of the Yamal-Nenets Autonomous Area; it occurred due to a significant epizooty among deer $[13,14]$. Anthrax epizooties are annually registered among farm and wild animals in Asia, Africa, and South America and it often results in wide-scale outbreaks among people. A large anthrax outbreak was detected in May-June 2017 in India, Pakistan, and Bangladesh [15]. Animals get infected with anthrax mostly due to grazing in sanitary protected zones near anthrax cattle burials and fodder procuring in such areas. Another significant role belongs to cattle vaccination and its scales as they should cover all livestock. The infection potential is enhanced by significant number of soil foci that can represent a threat for a long time and cause periodical outbreaks among farm animals and people. But the greatest threat for people and animals is created by anthrax cattle burials. There are approximately 35 thousand stationary soil foci on the territory of Russia where the situation with anthrax is rather adverse; 7,940 out of them are cattle burials [9].

Over the last 50 years substantial areas in the cryolithozone located in the European northern part of the country have thawed either completely or partially; it is especially true for zones located near the southern permafrost zone border.

Our research goal was to get a clear picture of the current situation with anthrax cattle burials located in this zone, especially given the climatic changes occurring at the moment and their influence on the cryolithozone; another goal was to estimate their future condition. It is important for native people who live in tundra and breed their numeral deer herds three. To achieve these goals, we had to solve the following tasks. First, we performed preliminary analysis of anthrax cattle burials prevalence in the European northern part of the country and places where a situation was adverse as per anthrax. Locations of such land spots that were partially shown on the epizootic map of the Nenets Autonomous Area ${ }^{2}$ were compared with available data on the current situation in the cryolithozone located in the European northern part of the country ${ }^{1}$ [16-21]. It was necessary to estimate future changes in the cryolithozone and highlight new arising problems associated with anthrax cattle burials prevalence in the region and to suggest ways to solve them.

Data and methods. We have performed cartographic analysis of several permafrost maps drawn as per actual and predicted data; the results allow us to conclude that there has been significant «restructuring» of geocryological conditions existing in the European northern part of Russia [16-21]. This restructuring involved southern borders of the permafrost zones moving dozen kilometers to the north as well as a significant increase in capacity of blind-end taliks that had been existing prior to the examined period; there was also a decrease in permafrost area due to new taliks occurring, a substantial rise in permafrost temperature, and thermal karst slumps development [17, 22, 23]. Permafrost degradation predicted by 2020 will be much less apparent than over 1970-2005; but after 2020 we can expect greater permafrost degradation due to heating effects produced by growing greenhouse gases emission from permafrost [24].

Results and discussion. Temperature is a most significant property that determines condition of the cryolithozone. Thus, the greatest changes in permafrost temperatures (increase by $0.6-1{ }^{\circ} \mathrm{C}$ ) occur in the eastern part of the Nenets Autonomous Area and Komi Republic (Urals, Pai-Khoi). Here we should pay close attentions to several districts that are unfavorable in terms of anthrax spread; they are river basins of Malaya Usa, Bolshaya Syr'yaga, Khal'mel'shor (Komi), Yunkoshor, areas close to the Kara bay, and Tab'yu river (The Nenets Autonomous Area) [19].

\footnotetext{
${ }^{2}$ The epizootic map of the Nenets Autonomous Area. Naryan-Mar, OGU NAO The Nenets Information-Analytical Center Publ., 2010.
} 
0.4-0.6 ${ }^{\circ} \mathrm{C}$ temperature rise in permafrost occurs on territories located to the east from Porchtyvys and Syadeyu rivers. There are also areas here that are adverse as per anthrax; they are river basins of Porchtyvys, Syadeyu, Adz'va, Pyayu, areas close to Vashutkiny lakes, Savauy, Syarnayu, Yareyu, and Ynkoshor rivers.

$0.2-0.4{ }^{\circ} \mathrm{C}$ temperature rise in permafrost has been detected practically on the whole Nenets Autonomous Area territory excluding the Pechora bay shore and the Barents sea shore where temperature will grow only slightly, less than by $0.2^{\circ} \mathrm{C}$. Thus, an ascending trend in average annual rock temperature detected at the Bolvanskiy stationary post amounted to $0.04{ }^{\circ} \mathrm{C} /$ per year on average for different landscapes. In 1980-ties, average annual permafrost temperature taken at 10 meters deep underground changed from -0.8 to $-2.5^{\circ} \mathrm{C}$, and then grew by $0.2 \ldots 1.2{ }^{\circ} \mathrm{C}$, and a range of changes in average annual permafrost temperature in different landscapes decreased by almost 3 times and now amounts to $-0.6 \ldots-1.2^{\circ} \mathrm{C}$. Layers prone to seasonal thawing thawed more considerably in the southern tundra close to the Bolvanskiy stationary post, starting from 2000, from 1.2 meters (2000) to 1.8 meters (2016). The latter figure is greater than potential freezing depth in this region; it indicates that permafrost roof has started to go down [21]. From 2005 to 2020 thawing depth varied from 1 to 2 meters near Vashutkiny lakes and the western Adz'va river basin; up to 1 meter, near Korataikha river; up to 2 meters, near Yun'yakha and Yareyu river; from 2 to 4 meters, near Ynkoshor river; up to 1 meter, near the Kara bay; up to 1 meter, near Tab'-Yu river.

In the northern part of the Nenets Autonomous Area (the Barents and Kara sea shore) sporadic talik zones might occur in areas that are adverse as per anthrax. These areas include zones located to the south from the Bolvanskaya bay, Urer'yakha and Ynkshor rivers, and Amdermy settlement (thawing depth is up to 1 meter).

Permafrost cartographic analysis allows stating the following. Firstly, over 1970-2020 there has been a substantial decrease in holo- cene permafrost that goes down from the earth surface and that has thawed completely in the southern regions; this fact should be taken into account when anthrax cattle burials are estimated. As a result, the southern border of this permafrost area has moved to the north by 30 $40 \mathrm{~km}$ on the Pechora lowlands and the Kanin peninsula; on the Priuralye mounting plains the border has moved as far as $80 \mathrm{~km}$ to the north $[18,19]$. Secondly, multiple firn blindend taliks have occurred in areas between rives in non-continuous permafrost zone and southern parts of continuous permafrost. This fact, together with temperature rise in permafrost up to minus $2{ }^{\circ} \mathrm{C}$ and even higher allows stating that borders of non-continuous and continuous permafrost have moved to the north by $15-20 \mathrm{~km}$ in the lowland tundra and many dozens $\mathrm{km}$ in the Priuralye and PaiKhoi [18]. Thirdly, rise in permafrost temperature that occurs almost everywhere has resulted in thermal karst processes being activated also almost everywhere within landscapes created by quaternary mineral deposits [20].

Having analyzed the situation with permafrost and anthrax spread in the Nenets Autonomous Area over a period from 1970 to 2010, we can make certain assumptions on its future prospects. Territories with their foundation being sand deposits that had long been frozen permanently accounted for a substantial part of the Nenets Autonomous Area located its border with Komi Republic. They thawed practically completely or partially over a period from 1970 to 2020 . This zone includes territories located to the south-east from Naryan-Mar city and areas where anthrax occurs and spreads are spotted in it. These areas are vicinity of Naryan-Mar, basins if Kuya, Voyvozh, Belaya-Yu, Norbein-Yu, KhalmerYu, Kolva, Kolvavis, Paivis, Neruyu, Vomles'yu, Kharutayu, and Leviy Foma-Yu rivers. Geocryological situation has changed considerably on this territory as it has become more watery and boggy and cryogenic processes have been activated there. A significant part of continuous permafrost in the Nenets Autonomous Area (located along the line between 
Naryan-Mar and Vashutkiny lakes, $68^{\circ}$ n.1.) transformed into non-continuous one over 1970-2020 as it became apparent via talik zones occurrence. Thus, from 1970 to 2020 thawing depth varied from 6 to 8 meters near Tedin'yakha, Pekhekheyakha and Urenyakha rivers (areas that are adverse as per anthrax); from 4 to 6 meters near Vashutkiny lakes; from 8 to 9 meters, in the western part of Adz'va river; from 5 to 7 meters, near Kortaraikha river; from 6 to 10 meters, near Yun'yakha and Yareyu rivers; from 6 to 12 meters, near Yunkshor river; from 5 to 7 meters, near the Kara bay; from 4 to 6 meters, near Tab'-Yu river.

In Arkhangelsk region there have been no anthrax cases among people registered for more than 80 years in areas that are prone to seasonal freezing [25]. The last anthrax case among animals (a pig) was registered in Uima settlement located in Primorskiy region. There are 24 anthrax cattle burials in Ark- hangelsk region. It is unclear who is responsible for 8 of them, including 4 burials located in Krasnoborskiy district; 2 burials, Nyandomskiy district; 1 burial in Onezhskiy district and 1 burial in Pinezhskiy district. Unfavorable epizootic situation in terms of anthrax creates a threat that infected animals or raw materials and agricultural products that contain anthrax agent spores can be brought to Arkhangelsk region.

Today in Arkhangelsk region there are 113 cattle burials (biothermal pits), 24 of them being anthrax burials. All anthrax cattle burials conform to veterinary and sanitary requirements. At the present tedious work is being performed both in Russia in general and Arkhangelsk region in particular aimed at maintaining anthrax cattle burials and biothermal pits in proper veterinary and sanitary condition. Animals are vaccinated against anthrax in areas that are adverse as per this factor (Table).

Table

Municipal districts in Arkhangelsk region where anthrax cattle burials are located (taken as per March 20, 2009)

\begin{tabular}{|c|c|c|c|c|c|}
\hline \multirow[b]{2}{*}{ Municipal district } & \multicolumn{2}{|c|}{ Overall number of burials } & \multicolumn{3}{|c|}{ Cattle burials } \\
\hline & $\begin{array}{c}\text { Location } \\
\text { not detected }\end{array}$ & $\begin{array}{c}\text { Location } \\
\text { not detected }\end{array}$ & Closed & Operating & Anthrax burials \\
\hline Arkhangelsk & 1 & - & - & - & - \\
\hline Velskiy & 7 & 19 & 11 & 8 & 9 \\
\hline Verkhnetoemskiy & - & 15 & 11 & 4 & - \\
\hline Vilegodskiy & - & 7 & - & 7 & - \\
\hline Vinogradovskiy & - & 7 & 4 & 3 & 1 \\
\hline Kargopolskiy & 8 & 10 & 2 & 8 & - \\
\hline Konoshskiy & 1 & 3 & 2 & 1 & 2 \\
\hline Kotlasskiy & 1 & 6 & 2 & 4 & 1 \\
\hline Krasnoborskiy & 11 & 11 & 4 & 7 & 4 \\
\hline Lenskiy & - & 3 & 2 & 1 & - \\
\hline Leshukonskiy & - & 7 & - & 7 & - \\
\hline Mezenskiy & - & 8 & 1 & 4 & 1 \\
\hline Nyadomskiy & 2 & 5 & 2 & 3 & 2 \\
\hline Onezhskiy & - & 2 & 1 & 1 & 1 \\
\hline Pinezhskiy & - & 1 & 1 & - & 1 \\
\hline Plesetskiy & 2 & 8 & 2 & 6 & - \\
\hline Primorskiy & - & 4 & - & 4 & - \\
\hline Ust’yanskiy & 2 & 5 & 1 & 4 & - \\
\hline Kholmogorskiy & - & 12 & 3 & 9 & 1 \\
\hline Shenkurskiy & - & 20 & 7 & 13 & 1 \\
\hline Total & 35 & 150 & 56 & 94 & 24 \\
\hline $\begin{array}{l}\text { The Nenets } \\
\text { Autonomous Area }\end{array}$ & 19 & - & - & - & - \\
\hline
\end{tabular}


Conclusion. In our opinion, it is necessary to continue complex monitoring examinations of anthrax cattle burials in potentially hazardous areas where geocryological processes are activated [14, 19, 26]. Unregistered anthrax cattle burials can cause a growth in epidemic outbreaks and a good example here is an emergency that occurred in the YamalNenets Autonomous Area. To reduce the detected risks, it is necessary to bind unregistered anthrax cattle burials to geographic maps as it was done in Stavropol region with the use of a geoinformation system [27].

At present geocryological conditions in the European northern part of Russia are changing considerably. The southern borders of continuous permafrost and cryolithozone are moving dozens $\mathrm{km}$ to the north [28]. There is a considerable growth in capacity of blind-end taliks that have existed before and permafrost area is declining due to new taliks occurrence; there is also a considerable increase in permafrost temperature and thermal karst slumps are developing. It all may lead to anthrax cattle burials destruction, especially in vulnerable tundra zones, both in permafrost areas and areas prone to seasonal freezing. Anthrax spores can be released from thawing layers in these areas where annually many thousands deer migrate from north to south and back. A serious problem here is low awareness among native population about risks caused by anthrax. Besides, permafrost degradation, combined with factors related to human activities (for example, oil and gas extraction), brings about changes in culture and traditions of native deer-breeding communities; it may result in changing routes and periods of deer grazing. When accomplishing complex monitoring, it is necessary to examine deer-breeding communities movements, animal migration routes, and anthrax spores penetration into seasonal-thawing layers caused by permafrost degradation. Such an approach, combined with monitoring over seasonal-thawing layers and permafrost in areas where the risks are the highest and studies on anthrax contagion in the European northern part of the country, can be useful for determining mechanisms of the disease spread in the Arctic regions and ultimately for taking relevant targeted preventive measures. In order to prevent emergencies in zones where geocryological processes are activated it is necessary to accomplish preventive temperature measurements on territories where cattle burials are located, to assess geocryological threats, and to create mathematical models for predicting negative events. It is also necessary to accomplish certain antiepidemic, anti-epizootic, and preventive activities.

Funding. The research was accomplished due to financial support provided by Russian Scientific Fund Grant No. 20-77-10057 «Diagnostics of permafrost degradation basing on isotope tracers $(234 \mathrm{U} / 238 \mathrm{U}, \delta 18 \mathrm{O}+\delta 2 \mathrm{H}, \delta 13 \mathrm{C}+14 \mathrm{C}) »$, the project supervised by E.Yu. Yakovlev, Candidate of Geological and Mineralogical Sciences.

Conflict of interests. The authors declare there is no any conflict of interests.

\section{References}

1. Gavrilov V.A. Biologicheskaya opasnost' sibireyazvennykh skotomogil'nikov i perspektivy resheniya sushchestvuyushchei problemy [Biological threat caused by anthrax cattle burials and prospects of finding solution to the existing problem]. Zhizn' bez opasnostei. Zdorov'e. Profilaktika. Dolgoletie, 2008, no. 4-1, pp. 81-84 (in Russian).

2. Bulgakova T. Climate change, vulnerability and adaptation among Nenets reindeer herders. Community Adaptation and Vulnerability in Arctic Region, 2010, pp. 83-105. DOI: 10.1007/97890-481-9174-1

3. Revich B.A., Podolnaya M.A. Thawing of permafrost may disturb historic cattle burial grounds in East Siberia. Glob. Health Action, 2011, no. 4, pp. 8482. DOI: 10.3402/gha.v4i0.8482

4. Revich B., Tokarevich N., Parkinson A.J. Climate change and zoonotic infections in the Russian Arctic. Int. J. Circumpolar Health, 2012, no. 71, pp. 18792. DOI: 10.3402/ijch.v71i0.18792 
5. Simonova E.G., Galkin V.V., Loktionova M.N., Ladnyi V.I. Anthrax cattle burial grounds in Russia and their biosafety. Zhurnal mikrobiologii, epidemiologii i immunobiologii, 2010, no. 4, pp. 23-26 (in Russian).

6. Simonova E.G., Kartavaya S.A., Loktionova M.N., Ladnyi V.I. Epidemiological hazard of anthrax animal burials: theoretical and methodological aspects. Meditsina v Kuzbasse, 2013, vol. 12, no. 2, pp. 26-31 (in Russian).

7. Kangbai J., Momoh E. Anthropogenic climatic change risks a global anthrax outbreak: a short communication. J. Trop. Dis, 2017, vol. 5, no. 4, pp. 2. DOI: 10.4172/2329-891X.1000244

8. Walsh M.G., de Smalen A.W., Mor S.M. Climatic influence on anthrax suitability in warming northern latitudes. Sci. Rep, 2018, vol. 18, no.8 (1), pp. 9269. DOI: 10.1038/s41598-018-27604-w

9. Koval'chuk N.A. Siberian cattle burial grounds: actual problems. Izvestiya Rossiiskoi Voennomeditsinskoi akademii, 2019, vol. 1, no. S1, pp. 214-216 (in Russian).

10. Dugarzhapova Z.F., Chesnokova M.V., Ivanova T.A., Kosilko S.A., Balakhonov S.V. Improvement of methodical approaches to investigation of anthrax burials and animal burial sites. Problemy osobo opasnykh infektsii, 2019, no. 4, pp. 41-47 (in Russian).

11. Dyagilev G.T., Chernyavskii V.F., Egorov I.Ya., Sofronova O.N., Nikiforov O.I. Epizootological and epidemiological monitoring of anthrax in the arctic and eastern zones of Yakutia. Prirodnye resursy Arktiki i Subarktiki, 2019, vol. 24, no. 2, pp. 95-105 (in Russian).

12. Hueffer K., Drown D., Romanovsky V., Hennessy T. Factors Contributing to Anthrax Outbreaks in the Circumpolar North. EcoHealth, 2020, vol. 17, pp. 174-180. DOI: 10.1007/s10393-020-01474-z

13. Selyaninov Yu.O., Egorova I.Yu., Kolbasov D.V. Anthrax in Yamal: reemergence causes and diagnostic issues. Veterinariya, 2016, no. 10, pp. 3-7 (in Russian).

14. Suranova T.G., Prosin V.I., Seminog V.V., Goryacheva N.G., Avitisov Anthrax P.V. in Yamal: results of liquidation of consequences of emergency situation. Meditsina katastrof, 2017, vol. 97, no. 1, pp. 38-42 (in Russian).

15. Terebova S.V. The monitoring of anthrax outbreaks. Agrarnyi vestnik Primor'ya, 2017, vol. 8, no. 4, pp. 42-47 (in Russian).

16. Oberman N.G., Mazhitova G.G. Permafrost dynamics in the north east of European Russia at the end of the $20^{\text {th }}$ century. Norsk Geografisk Tidsskrift, 2001, vol. 4, no. 55, pp. 241-244. DOI: $10.1080 / 00291950152746595$

17. Vechnaya merzlota i osvoenie neftegazonosnykh raionov [Frozen earth and oil-and-gas-bearing regions development]. In: E.S. Mel'nikova, S.E. Grechishcheva eds. Moscow, GEOS Publ., 2002, 402 p. (in Russian).

18. Oberman N.G., Shesler I.G. Sovremennye i prognoziruemye izmeneniya merzlotnykh uslovii Evropeiskogo severo-vostoka Rossiiskoi Federatsii [Contemporary and predicted changes in frozen earth in the north-east European part of the RF]. Problemy Severa i Arktiki Rossiiskoi Federatsii: nauchnoinformatsionnyi byulleten', 2009, no. 9, pp. 96-106 (in Russian).

19. Iglovsky S.A. Anthropogenic changes of permafrost in the European north and their consequences. Water Resources, 2014, vol. 41, no. 7, pp. 865-871. DOI: 10.1134/S0097807814070069

20. Osadchaya G.G., Tumel' N.V., Koroleva A.M. Morphological structure of cryogenic landscapes of the Bolshezemelskaya tundra. Kriosfera Zemli, 2016, vol. 20, no. 3, pp. 14-23 (in Russian).

21. Vasil'ev A.A., Gravis A.G., Gubar'kov A.A., Drozdov D.S., Korostelev Yu.V., Malkova G.V., Oblogov G.E. [et al.]. Permafrost degradation: results of the long-term geocryological monitoring in the western sector of Russian Arctic. Kriosfera zemli, 2020, vol. 24, no. 2, pp. 15-30 (in Russian).

22. Perel'shtein G.Z., Pavlov A.V., Buiskikh A.A. Changes in the permafrost zone upon the modern climate warming. Geoekologiya. Inzhenernaya geologiya, gidrogeologiya, geokriologiya, 2006, no. 4, pp. 305-312 (in Russian).

23. Biskaborn B.K., Smith S.L., Noetzli J., Matthes H., Vieira G., Streletskiy D.A., Schoeneich P. [et al.]. Permafrost is warming at a global scale. Nature Communication, 2019, vol. 16, no. 10 (1), pp. 264. DOI: 10.1038/s41467-018-08240-4

24. Turetsky M.R., Abbott B.W., Jones M.C., Walter Anthony K., Olefeldt D., Schuur E.A.G., Koven C. [et al.]. Permafrost collapse is accelerating carbon release. Nature, 2019, vol. 569, no. 7754, pp. 32-34. DOI: 10.1038/d41586-019-01313-4 
25. Iglovskii S.A., Shavrina E.V., Shvartsman Yu.G. Razvitie geokriogennykh protsessov na territorii Belomorsko-Kuloiskogo plato Arkhangel'skoi oblasti [ Geocryological processes development on the Belomorsko-Kuloyskoye plateau in Arkhangelsk region]. Materialy nauchno-prakticheskoi konferentsii, posvyashchennoi 25-letiyu GPZP Arkhangel'sk, 1999, pp. 52-54 (in Russian).

26. Stella E., Mari L., Gabrieli J., Bertuzzo E. Permafrost dynamics and the risk of anthrax transmission: a modelling study. Sci. Rep., 2020, no. 10, pp. 16460. DOI: 10.1038/s41598-020-72440-6

27. Buravtseva N.P., Mezentsev V.M., Ryazanova A.G., Golovinskaya T.M., Degtyarev D.Yu., Pazenko A.N., Semenova O.I., Kulichenko A.N. Use of geographic information systems for creation of electronic database of anthrax burial sites in the Stavropol territory. Problemy osobo opasnykh infektsii, 2019, no. 4, pp. 31-36 (in Russian).

28. Oberman N.G., Lygin A.M. Prognosis of the degradation of permafrost in an example of European north-east of Russia. Razvedka i okhrana nedr, 2009, no. 7, pp. 15-20 (in Russian).

Iglovsky S.A., Kriauciunas V.V. Anthrax cattle burials as a potential threat caused by changes in cryolite zones in the Northern European part of Russia. Health Risk Analysis, 2021, no. 1, pp. 108-114. DOI: 10.21668/health.risk/2021.1.11.eng

Received: 04.12.2020

Accepted: 03.03.2021

Published: 30.03 .2021 
UDC 614,2., 614.3, 614.7., 614,9., 574.9.,551.582.,551.583.

DOI: $10.21668 /$ health.risk/2021.1.12.eng

Research article

\title{
CREATING ZONES IN ADMINISTRATIVE DISTRICTS LOCATED IN THE RUSSIAN ARCTIC REGION SPECIFIC AS PER THREATS OF CATTLE BURIALS DECAY DUE TO PERMAFROST DEGRADATION
}

\author{
B.A. Revich ${ }^{1}$, D.A. Shaposhnikov ${ }^{1}$, S.R. Raichich ${ }^{2}$, S.A. Saburova ${ }^{2}$, E.G. Simonova ${ }^{3}$ \\ ${ }^{1}$ Institute of Economic Forecasting of the Russian Academy of Sciences, 47 Nakhimovskii Ave., Moscow, 117418, \\ Russian Federation \\ ${ }^{2}$ Central Research Institute of Epidemiology, 3A Novogireevskaya Str., Moscow, 111123, Russian Federation \\ ${ }^{3}$ I.M. Sechenov First Moscow State Medical University, 2/6 Bol'shaya Pirogovskaya Str., Moscow, 119435, \\ Russian Federation
}

Climatic changes have already resulted and will continue to result in gradual degradation of active upper layers in permafrost due to increased average air temperature in summer. Anthrax is an example of a climate-depending bacterial infection; anthrax agent creates spores that remain viable for a long period of time they spend in cryptobiosis in permafrost. Apparent permafrost degradation is already detected in most arctic regions in Russia and it can lead to anthrax burials decay thus creating elevated risks of the infection among farm animals and people who live on these territories.

Our research goal was to create specific zones in municipal districts via combining data on permafrost, number of anthrax cattle burials, ascending trends in average long-term temperatures, and population density.

We developed two relative hazard coefficients for characterizing anthrax outbreaks probability for animals and local population. Basing on numeric values obtained for these two coefficients, 70 administrative districts located in 15 RF subjects in the Arctic zone were listed in a descending order as per risks of the infection occurrence. We created two score scales showing relative hazard; they indicated that the highest population risk was typical for urban districts as population density there was much high than in rural ones. Our calculations should be helpful for determining priorities when preventive activities are developed on arctic and sub-arctic territories that are endemic as per anthrax. It is also important to obtain an actual list of cattle burials and to develop spatial-time models showing anthrax outbreaks occurrence taking into account climatic warming and permafrost degradation.

Key words: Arctic, Yakutia, climate warming, permafrost, health risks, cattle burials, anthrax.

The founder of Soviet geocryology Mikhail Sumgin introduced the term «permafrost» in geology literature in 1927. Modern geologists also use the term "cryolithozone» as a synonym, to refer to the uppermost layer in the earth's crust, which is characterized throughout the entire year or for at least a short time by a freezing temperature in soils and rocks.
Depending on the frequency with which soil and rock temperatures pass through $0{ }^{\circ} \mathrm{C}$ in the course of the year, the cryolithozone is divided into the layer of short-term and seasonal freezing and thawing, or the «active layer», and the perennial cryolithozone.

The climate in the Arctic currently changes faster than elsewhere on the globe. The rate of

(C) Revich B.A., Shaposhnikov D.A., Raichich S.R., Saburova S.A., Simonova E.G., 2021

Boris A. Revich - Doctor of Medical Sciences, Professor, Head of Laboratory for Environment Quality Prediction and Population Health (e-mail: brevich@yandex.ru; tel.: +7 (499) 129-18-00; ORCID: https://orcid.org/0000-0002-7528-6643).

Dmitry A. Shaposhnikov - Candidate of Physical and Mathematical Sciences, Senior researcher at the Laboratory for Environment Quality Prediction and Population Health (e-mail: dshap2014@gmail.com; tel.: +7 (499) 129-36-33; ORCID: https://orcid.org/0000- 0001-9191-1974).

Stefan R. Raichich - Junior researcher at the Laboratory for Epidemiology of Natural Foci Infections (e-mail: anthraxcrie@gmail.com; tel.: +7 (495) 672-11-73; ORCID: https://orcid.org/0000-0002-7734-7382).

Svetlana A. Saburova - Candidate of Medical Sciences, researcher at the Laboratory for Epidemiology of Natural Foci Infections (e-mail: anthraxcrie@gmail.com; tel.: +7 (495) 672-11-73; ORCID: https://orcid.org/0000-0002-9332-0526).

Elena G. Simonova - Doctor of Medical Sciences, Professor at the Department for Epidemiology and Contemporary Vaccine Prevention Technologies (e-mail: simonova_e_g@mail.ru; tel.: +7 (495) 602-12-75; ORCID: https://orcid.org/00000001-7179-9890). 
increase in the mean annual temperatures over the last four decades (1976-2018) in the Arctic (approximated linearly) is approximately four times higher than the global average [1]. Relatively slow warming could not change the condition of permafrost significantly, but cryolithozone degrades more rapidly under greater warming rates [2]. The rise in the air temperatures gradually warms up the upper permafrost layer. IPCC experts projected a $90 \%$ decrease in the total area of perennial permafrost by 2100 , with an accelerated degradation occurring on a territory equal to $20 \%$ of cryolithozone [3, 4]. The future scenarios of permafrost degradation contain large uncertainties, as they rely on rather generalized assumptions about its properties.

The model-based projections of the trends in air temperatures depend upon the region of interest and GHG emission scenarios. The expected increments in the mean annual temperatures in the selected regions of Russian Arctic over the $21^{\text {st }}$ century were derived from the regionalized climate model under RCP 4.5 emission pathway as follows: $+3.0^{\circ} \mathrm{C}$ in Archangelsk, $+2.0{ }^{\circ} \mathrm{C}$ in Yakutsk. The same increments under RCP8.5 are $+5.0^{\circ} \mathrm{C}$ in Archangelsk and $+3.3{ }^{\circ} \mathrm{C}$ in Yakutsk [5]. The permafrost will gradually melt to remain only in the high mountains and the plains in the northern part of East Siberia and Far East.

Some geocryology scientists believe that permafrost degradation takes place if the upper layer in a cryolite cross-section is exposed to positive mean annual temperatures [6]. This study uses the summer temperatures as an indicator that permafrost degrades. Summer temperatures rise slower than annual mean temperatures in the circumpolar regions. It is during the summer season that permafrost melts down most intensely and the roof of frozen rock sags. The dynamic geocryology models, which link air temperatures to upper permafrost temperatures, are still imprecise, and their predictions vary greatly. According to the following research work, the rise in global mean air temperature by $2{ }^{\circ} \mathrm{C}$ will lead to complete thawing of $15-20 \%$ of today's per- mafrost area [7] whereas another model predicts even greater reductions: by $25-65 \%$ [8].

Perennial permafrost areas in Russian Arctic include the northern European part of Russia (Nenets Autonomous Oblast - NAO), the Urals (Sverdlovsk Oblast), West Siberia (Yamal), the greater part of East Siberia (Krasnoyarsk Krai and Yakutia), Far East (Chukotka Autonomous Oblast, Kamchatka Krai). The rising trends in the temperatures of upper layer in permafrost have been confirmed by numerous field measurements conducted in continuous, sporadic and patchy permafrost areas, and linked to global warming. During the period 1961-2003, temperature increments in permafrost soils at 1.6-meter depth varied between 0.1 and $1.2^{\circ} \mathrm{C}$. The measurements taken at the stationary geocryological stations confirmed that these increments varied considerably even within the same municipal district [9].

Risks of natural focal infections. Permafrost areas degradation is directly linked to the risks of natural focal infections, particularly, to spore-forming bacteria. Prokaryote and eukaryote bacteria can retain viability in permafrost soils where the temperatures stay continuously below zero. Geologic age of these soils varied between several hundred thousand and 2-3 million years. In particular, aerobic and anaerobic bacteria and filamentous fungi have been found and identified in permafrost soils [10-12]. Viable cysts of free-living protozoa have been found in perennial permafrost by many paleobiologic researchers who hypothesised that these spores retained viability in cryptobiosis for several hundred thousand years. These findings confirmed possible reactivation of the pathogens under favourable conditions (thawing and melting of permafrost). This is quite likely to happen in Russian Subarctic during the currently observed climate change [13]. Increasing incidences of haemorrhagic fever with kidney syndrome, tick-borne encephalitis, Lime disease and Karelia fever (transmitted by Sindbis virus) have been reported in some regions of Sweden, Norway, Finland and the Russian Federation by international researchers. Climate change may increase the risks of infections due to several reasons: increases in areas where infectious agents 
survive, warmer winter conditions, and lower depths of snow cover $[14,15]$.

Siberian anthrax as a climate-dependent microbial infection. Epidemic outbreaks of smallpox, cholera, and Siberian anthrax frequently happened in Russian North between the XVII and the first half of the XIX century. The diseased animals were either buried in special burial sites or sometimes just left on the ground. There are over 60 such «field cemeteries» in Yamal peninsula [16]. The problem of anthrax re-emergence due to climate change became obvious when biologists discovered that Bacillus anthracis spores retain viability in permafrost soils for over 100 years. There are more than 520 «officially» catalogued Siberian anthrax cattle burials in Russian Arctic where reindeer and other farm animals were buried. However, another more recent publication mentions 285 such sites, and only 64 out of them meet the established sanitary requirements ${ }^{1}$ [17]. Some experts believe that the most sites fail to meet the sanitary norms due to insufficient communication between epidemiologic surveillance and veterinary authorities, descriptions of such sites being lost, inadequate epizootic maps and other reasons $[18,19]$. Besides, Siberian anthrax burials were insufficiently monitored or even neglected due to numerous reorganizations of the responsible state institutions [20].

The official catalogue of Siberian anthrax burials that we use in this paper lists 230 sites in Yakutia, 84 sites in Archangelsk Oblast, 48 sites in Karelia and 28 sites in Komi Republic ${ }^{1}$.

The statistics of Siberian anthrax outbreaks in Yakutia mentions 739 epizootic outbreaks among reindeer and horses between 1811 and 2019. They happened regularly each decade during this period. The last outbreak was recorded in 1993 [21]. Yakutia (now called Republic Sakha) administratively consists of 35 districts («Ulus»), and epizootic outbreaks were reported in 29 of them. People also caught this infection from cattle and deer [22]. Such profound epizootic-epidemiologic research was performed only in Yakutia, whereas the data on other Arctic regions are less detailed [23].

B. Revich and M. Podolnaya considered potential re-emergence of Siberian anthrax in the context of permafrost degradation near the cattle burial sites in their report [24]. Their hypothesis was confirmed in 2016 when a large scale epizootic outbreak happened in YamalNenets Autonomous Okrug (YANAO). The part of West Siberia located beyond the Polar Circle has long been infamous for Siberian anthrax: more than 70 epizootic outbreaks have been recorded there and there were cases of the disease among people who caught it from animals. A prolonged period of epizootic well-being led people to believe in a false concept Siberian anthrax cattle burials rehabilitated somehow. As a result, vaccination of reindeer was discontinued in 2007. An incredibly warm summer in 2016 in Yamal caused extremely deep seasonal melting of upper layer in permafrost. In some areas, the permafrost thawed at 2-meter depth [25]. During the summer 2016, the mean monthly air temperatures exceeded average long-term ones by $6.7^{\circ} \mathrm{C}$ in June and by $5.7^{\circ} \mathrm{C}$ in July. It is quite likely that these extremely warm summer temperatures contributed to the vegetation of $B$. anthracis colonies in deep frozen strata and their diffusion to the surface with thawed waters, and subsequent large-scale outbreak of epizooty among the reindeer.The local native people contracted this disease through contacts with raw meat. As a result, 24 people became ill, and one 12-years old child died from alimentary contamination [26]. Russian Agricultural Surveillance reported 33 Siberian anthrax outbreaks among reindeer between 2010 and 2016 [27]; single cases of this disease among reindeer were reported in Canada and Scandinavia, but humans have not been infected. This is explained by higher level of education, regular vaccination and updated maps of cattle burials [28].

\footnotetext{
${ }^{1}$ Cadastre of stationary unfavorable Siberian anthrax sites in the Russian Federation. In: B.L. Cherkassky ed. Moscow, Intersen Publ., 2005, 829 p.
} 
There are no published data on spatial statistical relationships between permafrost degradation rates and Siberian anthrax outbreaks in Russian Arctic. The goal of this project was to create a simplified model showing a possible causal relationship between these variables. The authors combined data on permafrost degradation rates, the number of cattle burials, and population density in administrative districts within Russian cryolithozone. For each district, we calculated the hazard index (HI) of future Siberian anthrax outbreaks and linked this index to the observed trends in climate change. All administrative districts were then ranked according to the calculated HI values. The obtained HI values are relative and can be used only to compare the districts between each other according to relative hazard to the local population. The authors did not attempt to calculate actual risks (or probabilities) of future outbreaks as this would require more complex modeling techniques (e.g., models showing ecological niches where Siberian anthrax agent occurred). The statistics on recent outbreaks in administrative districts can be used to confirm the validity of obtained ranking a posteriori.

Materials and methods. The study area. The authors considered the administrative districts with continuous, island-like or patchy permafrost. The numbers of Siberian anthrax cattle burial sites were taken from Cadastre of stationary unfavorable Siberian anthrax sites in the Russian Federation. This Cadastre is maintained by the Federal Service for Surveillance over Consumer Rights protection and Human Well-being (Rospotrebnadzor) and lists the settlements, or other territories, where the Siberian anthrax outbreaks have been registered among cattle or people.

According to the recommendations by Rospotrebnadzor, the whole territory of stationary unfavorable sites (SUS) should be considered as potentially unfavorable and risky in terms of future outbreaks. Seventy administrative districts have been included in this study, located in 15 Russian Federation regions (Table 1). The Cadastre also contains data on the number of «active years» for each site. The authors, at pre- sent, have not used these data due to two reasons: (1) data were unavailable for several regions in the Russian Federation, (2) some sites reported zero years of activity.

Table 1

Regions in the Russian Federation and the number of administrative districts included in the study

\begin{tabular}{|c|c|}
\hline RF region & $\begin{array}{c}\text { Number of } \\
\text { districts }\end{array}$ \\
\hline Murmansk region & 1 \\
\hline Arkhangelsk region & 2 \\
\hline Komi Republic & 11 \\
\hline Komi-Permiatsky Autonomous Okrug ${ }^{*}$ & 4 \\
\hline Nenets Autonomous Okrug & 1 \\
\hline Khanty-Mansi Autonomous Okrug & 4 \\
\hline Yamalo-Nenets Autonomous Okrug & 3 \\
\hline $\begin{array}{l}\text { Taymyr (Dolgano-Nenets) Autonomous } \\
\text { Okrug }\end{array}$ & 3 \\
\hline Krasnoyarsk region & 8 \\
\hline Republic Sakha (Yakutia) $^{* *}$ & 28 \\
\hline Chukotka Autonomous Okrug $^{* * *}$ & 1 \\
\hline Evenk Autonomous Okrug $^{* * *}$ & 1 \\
\hline Koryak Autonomous Okrug & 1 \\
\hline Magadan region $^{* * *}$ & 1 \\
\hline Kamchatka & 1 \\
\hline
\end{tabular}

Notes:

*Including Chusovskoi Urban Okrug in Perm region;

$* *$ The number here represents the greater out of two reported in (Cadaster 2005) and in (Dyagilev et al. 2019);

$* * *$ These regions were considered as single spatial units, and were added to the list of administrative districts located in other regions.

Hazard indices. For each district, two numbers were calculated: «territorial» and «population» hazard indexes. The former $\left(H I_{\text {terr }}\right)$ characterizes the hazard of Siberian anthrax outbreaks within a given territory, the latter $\left(\mathrm{HI}_{\mathrm{pop}}\right)$ measures relative risk of the disease outbreak among the population living in this district.

The territorial index is proportional to two values: (1) the number of the disease agents in cryptobiotic state in permafrost soil which can be measured by the number of stationary unfavorable sites $N$ within this territory and (2) permafrost warming rate. This rate is proportional to the gradient of summer temperatures $\Delta T_{\text {cryo }}$ within the upper layer in permafrost. As this gradient grows, seasonal permafrost thaw- 
ing increases the active layer depth and triggers disease agents activation.

$$
\begin{gathered}
H I_{\text {terr }}=N \cdot \Delta T_{\mathrm{MM \Gamma}} \\
\Delta T_{\text {cryo }}=\Delta T_{\text {air }} \cdot k
\end{gathered}
$$

Where $T_{\text {air }}$ is the change in the mean summer temperatures (June-August) between the two 30-year periods: 1960-1989 and 1990-2019. Temperature measurements were reported by the Federal Weather Service ${ }^{2}$ and taken at the nearest weather station for each district out of the network that included 518 Roshydromet stations. Local stations outside this network have not been considered for the study.

The coefficient $k$ showing how sensitive perennial permafrost is to changes in air temperatures is measured as a ratio between a change in cryolithozone temperature at 10-meter depth and the ground-level air temperature. The seasonal variations in cryolithozone temperature are negligible at this depth («the depth of zero seasonal variations» according to [6]). The recommended normative depth of Siberian anthrax cattle burial or a «biothermal pit» is also 10 meters $^{3}$. Actual depths could vary between 2 meters and 10 meters; the shallowest are plague pits and trenches, the deepest are «furnished burials», according to the available surveys on numerous Siberian anthrax burial sites.

The values of coefficient $k$ that characterizes sensitivity of permafrost to the rise in air temperatures were derived via interpolation from the map publicly presented at a meeting ${ }^{4}$. It varies from 0.3 to 0.8 and can be interpolated and rounded by 0.05 slots within this interval and it imposes a principle limitation on ultimate results precision. Strictly, the calculation of $\Delta T_{\text {cryo }}$ as specified by Eq. (2) at the depth of zero seasonal variations requires using changes in annual mean temperatures. The authors of this study used average summer temperatures for this purpose, because they are directly related to the hazard of reactivation of the agent of Siberian anthrax. For example, the record depth of seasonal thawing of the uppermost layer in permafrost $(2 \mathrm{~m})$ has been observed in Yamal peninsula during the extremely hot summer in 2016. This depth was greater than the long-term seasonal average by $10 \mathrm{~cm} \mathrm{[26].}$

Population hazard index $H I_{\text {pop }}$ was assumed to be the product of $H I_{\text {terr }}$ and the population density:

$$
H Q_{\text {pop }}=H Q_{\text {terr }} \cdot p o p / S \text {, }
$$

where pop and $S$ stand for the population and area of each district. For simplification, Eq. (3) neglects the influence exerted by neighboring districts on Siberian anthrax risks for population. Eq. 3 can be rewritten as

$$
H Q_{\mathrm{pop}}=\left(\Delta T_{\mathrm{MM \Gamma}} \cdot N / S\right) \cdot \text { pop }
$$

where the first term in the brackets is interpreted as the surface density of hazard sources, and the last term is the total exposed population.

Both hazard indices are relative and can only be used for comparison between the districts. Their absolute values do not measure actual risks or probabilities. The result chapter offers an interpretation of the obtained ranking by calculating the relative score associated with the position each district holds on the $H I_{\text {terr }}$ scale.

Eq. (3) implies that one may expect abnormally high $\mathrm{HI}_{\text {pop }}$ values for compact urban administrative districts since their squares are too small in comparison with squares typical for rural areas, for example, when urban districts are actually compact urban settlements (Naryan-Mar, Syktyvkar, and Lesosibirsk).

\footnotetext{
${ }^{2}$ Federal Service of Hydrometeorology and Environmental Monitoring posts these on the website of All-Russian Institute of Hydrometeorology Information. Available at: www.meteo.ru (12.09.2020).

${ }^{3}$ Sanitary and Veterinary Rules of Russian Agricultural Surveillance: Collection, utilization and removal of biological waste, Doc. № 13-7-2/469 of 04.12.1995. Rossel'khoznadzor. Available at: https://fsvps.gov.ru/fsvps/laws/165.html (12.09.2020).

${ }^{4}$ Osipov V.I., Sergeev D.O. Influence exerted by permafrost melting on the functioning of infrastructure in the Far North: a presentation at the meeting of scientific advisory panel of Russian State Committee on Natural Resources Rosprirodnadzor № 2 on 25.06.2020.
} 
Some urban municipalities administratively include rural outskirts which makes their total areas bigger. The authors used the maps showing administrative division of Russia and noticed that often an administrative district does not include its «capital». The examples are the towns of Kudymkar, Khanty-Mansiisk, and Minusinsk. Just like the city of Norilsk is not administratively the part of Taymyr Autonomous Area. In all such cases, the authors used the data on the current administrative division in the Russian Federation and obviously it influenced the ranking order of the districts by $H I_{\text {pop }}$ values.

Results and discussion. Identifying the nearest weather station for each district required extensive work with local administrative maps. About a half (36 out of 70 ) of the districts included in the study had their «own» weather stations - i.e., located on their territories. The longest distance between the nearest weather station and the border of a municipal district was Abansky district of Krasnoyarsk Krai (200 km); Gainsky and Kosinsky districts in Komi-Permiatsky Autonomous Oblast (160 and $170 \mathrm{~km})$.

The highest rise in summer temperatures between the periods 1960-1989 and 1990-2019 was registered in Salekhard $\left(+1.48^{\circ} \mathrm{C}\right)$ and the lowest in Murmansk $\left(+0.43{ }^{\circ} \mathrm{C}\right)$. All weather stations reported positive changes in summer temperatures over the examined period. Calculations of $\Delta T_{\text {cryo }}$ with Eq. (2) showed the greatest increment in Priuralsk district of Yamal-Nenets Autonomous Oblast $\left(+1.0^{\circ} \mathrm{C}\right)$ and the lowest in Kola district of Murmansk Oblast $\left(+0.2^{\circ} \mathrm{C}\right)$.

The available statistics on the numbers of stationary unfavorable sites showed that the greatest numbers were detected in Srednekolymsky and Mirninsky districts of Yakutia (30 and 29 sites).

Table 2 reports the ranking of the administrative districts by territorial and population hazard indices.

A relative score (1 to 6 ) for the territorial hazard index was also assigned basing on its actual calculated values in order to achieve more compact results presentation for better informing provided for all concerned parties. Having analyzed distribution of the estimated $H I_{\text {terr }}$ values we detected its maximum value in Srednekolymskiy district (21.26). The remaining values varied within the interval from 0.17 to 13.24 . These two values differ by less than two orders of magnitude. The scores were assigned linearly after dividing this interval into six equal bins numbered 1 to 6 . Since the width of each bin was equal to $(13.24-0.17) / 6=2.18$, then score $=I$ was assigned to all $H I_{\text {terr }}$ values within the interval $[0.17+(i-1) \cdot 2.18$; $0.17+i \cdot 2.18]$. This scale is a linear one, that is, districts that have scored 2 are approximately two times more hazardous than districts that have scored 1; districts that have scored 3 are about three times more hazardous, etc. Such a scale makes it easier to perceive the research results; still, this perception about relative hazards is valid only within the simples "thawing model" accepted in this work for the anthrax agent. We cannot yet calculate actual risks related to this agent activation. To determine the most relatively hazardous districts, we took those with their scores being 2 or higher; there were 28 such districts or $40 \%$ out of all the considered ones.

The scores of population hazard was calculated on a logarithmic scale, because the underlying distribution of $\mathrm{HI}_{\text {pop }}$ values had (nearly) exponential character. The values of population hazard index differ by five orders of magnitude, between 0.02 in Khatangsky district and 6,747.26 in Naryan-Mar urban okrug. For these reasons, the scores were calculated on a logarithmic scale according to Eq. (4):

$$
S=1+\lg \left(H I / H I_{\text {min }}\right)
$$

where $S$ is hazard given in scores. It follows from Eq. (4) that score $=1$ is assigned to $H I_{\text {terr }}$ values between 0.02 and 0.2 ; score $=2$ to the values between 0.2 and 2.0 , etc. The districts with score $=2$ are approximately ten times more hazardous than the districts with score $=1$; the districts with score $=3$ are approximately 100 times more hazardous than the districts with score $=1$, etc. The logarithmic scales of relative hazards have been previously used in science and engineering, as it meets our intui- 
tive perception of hazard by the intensity of its impacts: for example, Mercalli seismic intensity scale and the Palermo Technical Impact Hazard Scaleused by astronomers to rate the potential hazard of clash with a near-earth object (asteroid). Indeed, Eq. (4) is a specific manifestation of Weber Fechner basis psychophysics law (1860): $S=a \ln I+b$, the relationship between stimulus and perception is logarithmic. These examples are used here to justify the logarithmic relationship between the population hazard index and the perceived gravity of this hazard for the population.

Table 2 tells that several «urban okrugs» (districts) top the list of $H_{\text {pop }}$ values, with the respective scores between 4 and 6 . These are the towns of Naryan-Mar, Syktyvkar, Yakutsk and Lesosibirsk. The remaining districts have the scores between 1 and 3, of which 15 districts have score $=1 ; 30$ districts have score $=2$;

Table 2

Ranking of municipal districts by relative hazard of outbreaks of Siberian Anthrax among cattle (using territorial hazard index) and people (using population hazard index)

\begin{tabular}{|c|c|c|c|c|c|c|}
\hline \multicolumn{4}{|c|}{ Hazard for cattle } & \multicolumn{3}{|c|}{ Hazard for people } \\
\hline Subject of RF & Municipal district & $H I_{\text {terr }}$ & score & Municipal district & $H I_{\text {pop }}$ & score \\
\hline Yak-Arctic & Srednekolymsky & 21,26 & \multirow{5}{*}{6} & Naryan-Mar u.o. & 6747,26 & 6 \\
\hline Yak-West & Mirninsky & 13,24 & & Syktyvkar u.o. & 436,80 & 5 \\
\hline Yak-West & Niurbinsky & 12,45 & & Yakutsk u.o. & 357,38 & \\
\hline $\mathrm{NAO}$ & Naryan-Mar u.o. & 12,32 & & Lesosibirsku.o. & 75,85 & 4 \\
\hline Taimyr & Dudinka u.o. & 11,36 & & Chusovskoyu.o. & 17,71 & \\
\hline Taimyr & Ust-Yeniseisky & 9,54 & \multirow{3}{*}{5} & \begin{tabular}{|l|} 
Ukhtau.o. \\
\end{tabular} & 17,46 & \\
\hline Yak-East & Oimyakonsky & 9,13 & & Namsky & 14,75 & \\
\hline Chukotka & Chukotka AO & 9,08 & & Ust-Aldansky & 9,98 & \\
\hline Yak-Centre & Ust-Aldansky & 8,76 & \multirow{11}{*}{4} & Sosnogorsky & 6,78 & \\
\hline Yak-Centre & Amginsky & 8,20 & & Mirninsky & 5,76 & \\
\hline Yak-West & Viluisky & 8,19 & & Niurbinsky & 5,69 & \\
\hline КНMAO & Khanty-Mansiisky & 8,07 & & Churapchinsky & 5,53 & \\
\hline Koryak & Koryak AO & 8,02 & & Khangalassky & 5,22 & \\
\hline Evenk & Evenk AO & 7,61 & & Amginsky & 4,66 & \\
\hline Yak-Centre & Gorny & 7,45 & & Minusinsky & 4,40 & 3 \\
\hline Magadan & Magadan Oblast & 7,16 & & \begin{tabular}{|l} 
Viluisky \\
\end{tabular} & 3,71 & \\
\hline Yak-Centre & Namsky & 7,12 & & Khanty-Mansiisky & 3,51 & \\
\hline Yak-West & Verkhneviluisky & 6,82 & & Verkhneviluisky & 3,41 & \\
\hline Yak-Centre & Kobyaisky & 6,82 & & Kudymkarsky & 3,21 & \\
\hline Yak-Arctic & Oleneksky & 6,13 & \multirow{3}{*}{3} & Abansky & 3,06 & \\
\hline Yak-South & Olekminsky & 4,96 & & Syktyvdinsky & 2,69 & \\
\hline YANAO & Yamalsky & 4,54 & & Megino-Kangalassky & 2,31 & \\
\hline Yak-West & Suntarsky & 4,39 & \multirow{6}{*}{2} & Krasnoturansky & 2,20 & \\
\hline Yak-Center & Khangalassky & 3,94 & & Magadan Oblast & 2,17 & \\
\hline Yak-Center & Yakutsk u.o. & 3,83 & & Nadymsky & 2,05 & \\
\hline Yak-Center & Churapchinsky & 3,29 & & Gorny & 1,96 & 2 \\
\hline YANAO & Nadymsky & 3,17 & & \begin{tabular}{|l|} 
Sayansky \\
\end{tabular} & 1,95 & $\sum^{2}$ \\
\hline Komi & Sosnogorsky & 2,64 & & Tattinsky & 1,82 & \\
\hline
\end{tabular}

$\mathrm{NAO}=$ Nenets Autonomous Oblast (Region);

YANAO $=$ Yamal-Nenets Autonomous Oblast;

$\mathrm{KHMAO}=$ Khanty-Mansi Autonomous Oblast;

$\mathrm{KPAO}=$ Komi-Permiatsky Autonomous Oblast;

Yakutia is subdivided into the five economic zones: Arctic, Centre, West, East, and South;

u.o. $=$ urban okrug (district). 
Table 2 (Continued)

\begin{tabular}{|c|c|c|c|c|c|c|}
\hline \multicolumn{4}{|c|}{ Hazard for cattle } & \multicolumn{3}{|c|}{ Hazard for people } \\
\hline Subject of RF & Municipal district & $H I_{\text {terr }}$ & score & Municipal district & $H I_{\mathrm{pop}}$ & score \\
\hline Yak-Arctic & \begin{tabular}{|l} 
Zhigansky \\
\end{tabular} & 2,33 & & Priluzsky & 1,81 & \\
\hline Yak-Centre & Tattinsky & 2,12 & & Suntarsky & 1,79 & \\
\hline YANAO & Priuralsky & 2,07 & & Intau.o. & 1,67 & \\
\hline Yak-East & Tomponsky & 2,03 & & Pechora u.o. & 1,60 & \\
\hline Yak-East & Ust-Maisky & 1,97 & & Srednekolymsky & 1,27 & \\
\hline Komi & Intau.o. & 1,88 & & Kosinsly & 1,22 & \\
\hline Komi & Ukhtau.o. & 1,58 & & Dudinka u.o. & 1,15 & \\
\hline Krasnoyarsk & Abansky & 1,48 & & Gainsky & 1,08 & \\
\hline Krasnoyarsk & Sayansky & 1,48 & & Izhemsky & 0,91 & \\
\hline Komi & Priluzsky & 1,41 & & Elizovsky & 0,90 & \\
\hline KPAO & Gainsky & 1,37 & & Oimyakonsky & 0,84 & \\
\hline Yak-Arctic & Verkhoyansky & 1,34 & & Kobiaisky & 0,79 & \\
\hline Komi & Syktyvkarskyu.o. & 1,23 & & Olekminsky & 0,77 & $>2$ \\
\hline Yak-Arctic & Nizhnekolymsky & 1,17 & & Usinsku.o. & 0,66 & \\
\hline Komi & Izhemsky & 0,99 & & ChukotkaAO & 0,63 & \\
\hline Komi & Pechorau.o. & 0,95 & & Surgutsky & 0,56 & \\
\hline KPAO & Chusovskoyu.o. & 0,94 & & Irbeisky & 0,52 & \\
\hline Yak-Arctic & Verkhnekolymsky & 0,91 & & Yamalsky & 0,52 & \\
\hline Yak-Centre & Megino-Kangalassky & 0,88 & & Koryak AO & 0,51 & \\
\hline KHMAO & Kondinsky & 0,85 & & Kuraginsky & 0,51 & \\
\hline Komi & Syktyvdinsky & 0,82 & $>1$ & Idrinsky & 0,49 & \\
\hline Yak-Arctic & Bulunsky & 0,81 & > 1 & Priuralsky & 0,48 & \\
\hline Yak-Arctic & Momsky & 0,78 & & Kondinsky & 0,48 & \\
\hline KPAO & Kosinsky & 0,68 & & Ust-Kulomsky & 0,47 & \\
\hline KPAO & Kudymkarsky & 0,68 & & Ust-Yeniseysky & 0,36 & \\
\hline Kamchatka & Elizovsky & 0,57 & & Kniazhpogostsky & 0,31 & \\
\hline Krasnoyarsk & Minusinsky & 0,55 & & Kolsky & 0,25 & \\
\hline Krasnoyarsk & Krasnoturansky & 0,55 & & Tomponsky & 0,19 & \\
\hline Komi & Ust-Kulomsky & 0,53 & & Evenk AO & 0,17 & \\
\hline KHMAO & Berezovsky & 0,50 & & Ust-Maisky & 0,15 & \\
\hline KHMAO & Surgutsky & 0,47 & & Berezovsky & 0,13 & \\
\hline Komi & Usinskyy.o. & 0,47 & & Verkhoyansky & 0,11 & \\
\hline Taimyr & Khatangsky & 0,45 & & Leshukonsky & 0,09 & \\
\hline Yak-Arctic & Eveno-Batyntaisky & 0,45 & & Mezensky & 0,08 & \\
\hline Komi & Knyazhpogostsky & 0,41 & & Oleneksky & 0,08 & \\
\hline Krasnoyarsk & Irbeisky & 0,37 & & Zhigansky & 0,07 & \\
\hline Krasnoyarsk & Lesosibirsku.o. & 0,32 & & Nizhnekolymsky & 0,06 & \\
\hline Arkhangelsk & Leshukonsky & 0,31 & & Verkhnekolymsky & 0,06 & \\
\hline Arkhangelsk & Mezensky & 0,31 & & Momsky & 0,03 & \\
\hline Krasnoyarsk & Idrinsky & 0,27 & & Bulunsky & 0,03 & \\
\hline Krasnoyarsk & Kuraginsky & 0,27 & & Eveno-Batyntaisky & 0,02 & \\
\hline Murmansk & Kolsky & 0,17 & & Khatangsky & 0,02 & \\
\hline
\end{tabular}

and 21 districts have score $=3$. The highest risks of Siberian anthrax outbreak among local people for the remaining districts were detected in Chusovskoy and Ukhta urban okrugs, Namsky and Ust-Aldansky uluses (districts) in Yakutia. Taking the value of $\mathrm{HI}_{\text {pop }}$ in NaryanMar $(6,747.26)$ as the maximum, the values of this index in these four administrative districts are above $1 \%$ (promille) of this maximum.
Therefore, the above mentioned eight urban districts should be considered as the priority ones when it comes to the risks of Siberian anthrax outbreaks among people. The urban districts (okrugs) with the highest $H I_{\text {pop }}$ might not actually have the catalogued cattle burials on their current territories, because the borders between the administrative districts shifted in many instances. For example, Naryan-Mar ur- 
ban okrug once included Posyolok Iskatelei village, which later was added to Zapolyarny district. Ukhta district existed within Komi Autonomus Soviet Socialist Republic between 1939 and 1963. Chusovskoy district existed within Perm region between 1964 and 2004, but the town of Chusovskoy was not part of this district.

The order of ranking by $\mathrm{HI}_{\text {terr }}$ values differs from the order of ranking by $H I_{p o p}$ values. For the decision makers, both indicators of the perceived hazard should be informative.

The priority districts could be chosen as the sites for field experiments to validate the mathematical models showing propagation of paleobiologic infections. Geometry stratification model is an example of such models; it identifies an area with maximum risk of noxious microorganisms reactivation from the cryptobiotic state due to permafrost degradation [29]. According to the authors of this research, Yamal Peninsula and Nort-East of Yakutia have the highest risks. The present research confirmed their conclusions with respect to Yakutia: Srendekolymsky district in the Arctic Zone of Yakutia; Mirninsky and Niurbinsky districts in West Yakutia have the highest $H I_{\text {terr }}$ values. The advantage of the hazard scoring method used in the present research is that it takes into account both the permafrost degradation rate and the documented numbers of cattle burial sites located in districts with perennial permafrost.

Conclusions. The adverse consequences of climate change in the Arctic create the need to develop various adaptation techniques. The recommendations for the prevention of natural focal infectious diseases should consider the available data on the territories with the most intense permafrost degradation. The field measurements taken by the geologists should provide necessary data on territories with the greatest deformations of perennial permafrost crust. Because the maximum rise in summer air temperatures is expected near the Arctic Coast of Central Siberia, this region should become the focus of interest for the paleobiologic monitoring over the current state of historic cattle burial sites where the diseased animals were buried at the 2-10 meters' depths. Infected carcasses of diseased reindeer could be frequently found scattered on the ground instead of being buried in specially designated and constructed 'burial sites'. Such unorganized burials are called «pestilence fields» and are marked so on veterinary maps. The publishing of the "Cadastre of Siberian anthrax burial sites» should be regularly updated and revised because there are more than 1 million wild reindeer and 1 million farm reindeer in the Arctic region. Intensive economic development of this region in the conditions of climate change may lead to Siberian anthrax outbreaks if the exact data on the historic cattle burial sites are absent. Natural disasters, climate change, permafrost degradation, earth excavations and other engineering and construction projects can activate the agents of infectious diseases near the earth's surface. The anomalously hot summer in 2016 might not be the single reason of the Siberian anthrax outbreak in Yamal Peninsula that year; other reasons were unjustified refusal to vaccinate reindeer and people and low public awareness [30]. The papers [26, 30] suggested several preventive measures to control potential Siberian anthrax outbreaks. Closest attention should be paid to each single case of this disease among deer. The risks of disease propagation from the soil foci should be carefully monitored. It is very important to regularly update and revisit the list of cattle burial sites, to inform the public about the existing health risks and disease prevention practices, and to continue to vaccinate deer. The authors also recommend further research to improve the dynamic geospatial models of Siberian anthrax propagation in the environment, taking into account the observed trends in global warming and permafrost degradation in the Russian Arctic.

Funding. for this research came from the grant program of Russian Foundation for Fundamental Research 18-05-60146 «Medical and Biological Factors of Social and Economic Development of Russian Arctic: Analysis and Predictions»».

Conflict of interests. the authors declare there is no any conflict of interests. 


\section{References}

1. Edel'geriev R.S.Kh., Romanovskaya A.A. New approaches to the adaptation to climate change: the case of the arctic zone of Russia. Meteorologiya i gidrologiya, 2020, no. 5, pp. 12-28 (in Russian).

2. Iglovskii S.A. Anthropogenic transformation of permafrost conditions of the European north of Russia and their consequences. Arktika i Sever, 2013, no. 10, pp. 107-1124 (in Russian).

3. Pörtner H.-O., Roberts D.C., Masson-Delmotte V., Zhai P., Tignor M., Poloczanska E., Mintenbeck K. [et al.]. IPCC Special Report on the Ocean and Cryosphere in a Changing Climate IPCC 2019 Summary for Policymakers. Summary for Policymakers, 2019, 36 p.

4. Climate Change and Land: An IPCC Special Report on Climate Change, Desertification, Land Degradation, Sustainable Land Management, Food Security, and Greenhouse Gas Fluxes in Terrestrial Ecosystems. IPCC, 2019. Available at: https://www.ipcc.ch/srccl/ (12.09.2020).

5. Revich B.A., Shaposnikov D.A., Shkolnik I.M. Projections of temperature-dependent mortality in Russian subarctic under climate change scenarios: a longitudinal study across several climate zones. IOP Conf. Ser.: Earth Environ. Sci, 2020, vol. 606, no. 012050, pp. 10. DOI: 10.1088/1755-1315/606/1/012050

6. Vasil'ev A.A., Gravis A.G., Gubar'kov A.A., Drozdov D.S., Korostelev Yu.V., Malkova G.V., Oblogov G.E. [et al.]. Permafrost degradation: results of the long-term geocryological monitoring in the western sector of Russian Arctic. Kriosfera Zemli, 2020, vol. 24, no. 2, pp. 15-30. DOI: 10.21782/KZ15607496-2020-2(15-30)

7. Nelson F.E., Anisimov O.F., Shiklomanov N.L. Subsidence risk from thawing permafrost. Nature, 2001, vol. 19, no. 410, pp. 889-890. DOI: 10.1038/35073746

8. Mokhov I.I., Eliseev A.V. Modelirovanie global'nykh klimaticheskikh izmenenii v XX-XXIII vekakh pri stsenariyakh antropogennykh vozdeistvii RCP [Modeling global climatic changes in the $20^{\text {th }}-21^{\text {st }}$ centuries under RCP anthropogenic impacts]. Doklady Akademii nauk, 2012, no. 6, pp. 732-736 (in Russian).

9. Pavlov A.V., Malkova G.V. Small-scale mapping of trends of the contemporary ground temperature changes in the Russian north. Kriosfera Zemli, 2009, vol. 13, no. 4, pp. 32-39 (in Russian).

10. Vorobyova E., Soina V., Gorlenko M., Minkovskaya N., Zalinova N., Mamukelashvili A., Gilichinsky D., Rivkina E., Vishnivetskaya T. The deep cold biosphere: facts and hypothesis. FEMS Microbiol. Rev., 1997, no. 20, pp. 277-290. DOI: 10.1111/j.1574-6976.1997.tb00314.x

11. Rivkina E., Shcherbakova V., Laurinavichuis K., Petrovskaya L., Krivushin K., Kraev G., Pecheritsina S., Gilichinsky D. Biogeochemistry of methane and methanogenic archaea in permafrost. FEMS Microbiol. Ecol., 2007, vol. 61, no. 1, pp. 1-15. DOI: 10.1111/j.1574-6941.2007.00315.x

12. Kochkina G.A., Ivanushkina N.E., Karasev S.G., Gurina L.V., Evtushenko D.I., Ozerskaya S.M., Gavrish E.Yu., Spirina E.V., Gilichinskii D.A., Vorob'eva E.A. Survival of micromycetes and actinobacteria under conditions of long-term natural cryopreservation. Mikrobiologiya, 2001, vol. 70, no. 3, pp. 412-420 (in Russian).

13. Shatilovich A.V., Shmakova S.V., Gubin D.A., Gilichinskii L.A. Viable protists in arctic permafrost. Kriosfera Zemli, 2010, vol. 14, no. 2, pp. 69-78 (in Russian).

14. Mills J.N., Gage K.L., Khan A.S. Potential influence of climate change on vector-born and zoonotic diseases: a review and proposed research plan. Environ. Health Perspect., 2010, vol. 118, no. 11, pp. 1507-1514. DOI: 10.1289/ehp.0901389

15. Semenza J.C., Suk J.E., Estevez V., Ebi K.L., Lingren E. Mapping climate change vulnerabilities to infection diseases in Europe. Environ. Health Perspect, 2012, vol. 120, no. 3, pp. 385-392. DOI: 10.1289/ehp.1103805

16. Laishev K.A., Zabrodin V.A. Problemy veterinarnogo blagopoluchiya po infektsionnym boleznyam v Severnom olenevodstve [Issues related to veterinary well-being as per communicable diseases in the Northern deer-raising]. Farm. Animals., 2012, vol. 1, no. 1, pp. 36-40 (in Russian).

17. Pavlova S.N., Barakhova L.D. Riski vozniknoveniya chrezvychainykh situatsii na territorii Respubliki Sakha (Yakutiya) [Risks of emergencies in Yakutia]. Natsional'nye interesy: prioritety $i$ bezopasnost', 2013, vol. 9, no. 47 (236), pp. 44-52 (in Russian).

18. Galkin V.V., Loktionova M.N., Simonova E.G., Khadartsev O.S. Problems in the safety of anthrax cattle burial grounds. Epidemiologiya i infektsionnye bolezni, 2007, no. 6, pp. 55-57 (in Russian).

19. Gavrilov V.A. Perspektivy resheniya problem biologicheskoi opasnosti sibireyazvennykh skotomogil'nikov [Prospects for solving the issue related to biological hazards occurring due to anthrax cattle burials]. Dezinfektsiya. Antiseptika, 2010, vol. 1, no. 3, pp. 12-15 (in Russian). 
20. Gavrilov V.A., Gryazneva T.N., Seliverstov V.V. Soil hearth anthrax: realities and challenges. Veterinariya, zootekhniya i biotekhnologiya, 2017, no. 8, pp. 17-22 (in Russian).

21. Dyagilev G.T., Neustroev M.P. Epidemiological and epizootological situation on anthrax in the republic of Sakha (Yakutia). Veterinariya i kormlenie, 2019, no. 7, pp. 11-13 (in Russian).

22. Karataeva T.D., Vasil'eva A.A. Epizooticheskaya obstanovka po sibirskoi yazve i ee profilaktike v Respublike Sakha (Yakutiya) [Epizootic situation as per anthrax and its prevention in Yakutia]. Vestnik veterinarii, 2007, no. 40-41, pp. 106-112 (in Russian).

23. Dyagilev G.T., Chernyavskii V.F., Egorov I.Ya., Sofronova O.N., Nikiforov O.I. Epizootological and epidemiological monitoring of anthrax in the arctic and eastern zones of Yakutia. Prirodnye resursy Arktiki i Subarktiki, 2019, vol. 24, no. 2, pp. 95-105 (in Russian).

24. Revich B., Podolnaya M. Thawing of permafrost may disturb historic cattle burial grounds in East Siberia. Global Health Action, 2011, no. 4, pp. 8482. DOI: 10.3402/gha.v4i0.8482

25. Letom 2016 g. na fone krupnoi i prodolzhitel'noi temperaturnoi anomalii v Yamalo-Nenetskom avtonomnom okruge nablyudaetsya vspyshka zabolevaemosti olenei sibirskoi yazvoi. Press-reliz 6 avgusta 2016 [In summer 2016 a large and long-term temperature anomaly resulted in anthrax outbreak among deer in the Yamal-Nenets Autonomous Area. Press release issued on August 6, 2016]. Institut global'nogo klimata i ekologii imeni akademika Yu.A. Izraelya, 2016. Available at: http://old.igce.ru/page/news_06082016 (12.09.2020) (in Russian).

26. Opyt likvidatsii vspyshki sibirskoi yazvy na Yamale v 2016 godu [Experience gained in anthrax outbreak elimination on the Yamal peninsula in 2016]. In: A.Yu. Popova, A.N. Kulichenko eds. Izhevsk, OOO «Print-2» Publ., 2017, 313 p. (in Russian).

27. Terebova S.V. The monitoring of anthrax outbreaks. Agrarnyi vestnik Primor'ya, 2017, no. 4 (8), pp. $42-47$ (in Russian).

28. Susloparov G.A., Kuzin A.A., Lantsov E.V. Medical-geographic characteristics natural and social conditions of development of epidemic process in the Yamal-Nenets autonomous district. Vestnik Rossiiskoi voenno-meditsinskoi akademii, 2018, no. S1, pp. 196-199 (in Russian).

29. Perevertin K.A., Vasil'ev T.A. Ekstsessy riskov paleobiozagryazneniya landshaftov v usloviyakh global'nogo potepleniya [Elevated risks of paleobiological contamination caused by global warming]. Materialy Shestoi konferentsii «Matematicheskoe modelirovanie v ekologii «EkoMatMod-2019», 2019, pp. 158-160 (in Russian).

30. Simonova E.G., Kartavaya S.F., Titkov A.V., Loktionova M.N., Raichich S.R., Tolpin V.A., Lupyan E.A., Platonov A.E. Anthrax in the territory of Yamal: assessment of epizootiological and epidemiological risks. Problemy osobo opasnykh infektsii, 2017, no. 1, pp. $89-93$ (in Russian).

Revich B.A., Shaposhnikov D.A., Raichich S.R., Saburova S.A., Simonova E.G. Creating zones in administrative districts located in the russian arctic region specific as per threats of cattle burials decay due to permafrost degradation. Health Risk Analysis, 2021, no. 1, pp. 115-125. DOI: 10.21668/health.risk/2021.1.12.eng

Received: 05.11.2020

Accepted: 03.03.2021

Published: 30.03 .2021 


\title{
MEDICAL AND BIOLOGICAL ASPECTS RELATED TO ASSESSMENT OF IMPACTS EXERTED BY RISK FACTORS
}

UDC 575.174.015.3: 613.632: 546.49-121

DOI: $10.21668 /$ health.risk/2021.1.13.eng

Read

online

Research article

\section{ASSOCIATION BETWEEN HSPA1B, S100B, AND TNF- $\alpha$ GENE POLYMORPHISMS AND RISKS OF CHRONIC MERCURY POISONING}

\author{
Yu.I. Chernyak \\ East-Siberian Institute of Medical and Ecological Research, 3 Bldg., 12a microdistrict, Angarsk, 665827, \\ Russian Federation
}

We examined association between HSPA1B (+1267A/G, rs1061581), TNF- $\alpha(-308 G / A, r s 1800629)$, and S100B (C/T, rs9722) gene polymorphisms and chronic mercury poisoning (CMP).

PCR-RFLP analysis was used to examine a cohort consisting of 128 workers who were chronically exposed to mercury vapor; workers were distributed into two groups. The group 1 was made up of workers with long working experience who didn't have CMP $(n=46)$, the group 2 included patients with long-term CMP period $(n=82)$. In addition, we estimated frequencies of rs1061581genotypes in 298 practically healthy men from regional sub-population (group 3).

HSPA1B $(+1267 A / G)$ polymorphic variant was established to have more frequent carriage of both minor $G$ allele ( $p=0.003)$ and a rare $G G$ homozygous $(p=0.005)$ in the group 2 against the group $1.23 .2 \%$ patients from the group 2 turned out to have GG genotype and CMP was diagnosed in $95 \%$ people who had it. We didn't detect any differences in genotypes distribution among people from the examined occupational cohort (groups 1 and 2) against the group 3. GG-HSP1AB (+1267A/G) homozygous genotype was shown to be associated with CMP risks $(O R=13.57, p<0.0001$, recessive model). Haplotype $G-G$ (rs1061581-rs1800629) carriers were established to run 2.6 higher risks of CMP occurrence $(p=0.0098)$, and there was a significant linkage disequilibrium $D^{\prime}=0.459(p=0.0004)$ between a pair of the abovementioned polymorphic loci. These data indicate that there is genetic interaction between HSPA1B $(+1267 A / G)$ and TNF- $\alpha$ $(-308 G / A)$ loci in the examined cohort.

Overall, these results indicate that carriers of GG-HSPA1B $(+1267 A / G)$ genotype run high predictive risks of CMP occurrence.

Key words: mercury, chronic exposure, chronic mercury poisoning, gene polymorphism, heat shock proteins 70 , tumor necrosis factor, protein S100B, risk.

Earlier it was reported that regular medical examinations provided for personnel employed at caustic soda factories with mercury electrolysis technology made it possible to form occupational cohort of workers who were chronically exposed to metallic mercury vapors [1]. The named cohort included patients in a long-term period of chronic mercury poisoning (CMP) with severe clinical manifestations of intoxication and its progression, and by formation of organic lesions in the brain [2]. Patients from this group had signs that neurodegenerative proc- esses occurred in them; it stimulated our interest in heat shock proteins 70 (HSP70, HSPA1 genes) that played a key role in cytoprotection in case of neurodegenerative diseases [3]. It was established that carriage of rare CC-HSPA1A $(+190 \mathrm{G} / \mathrm{C})$ and GG-HSPA1B $(+1267 \mathrm{~A} / \mathrm{G})$ homozygotes and their combination was associated with high CMP risks [1]. Besides, carriers of GG-HSPA1B $(+1267 \mathrm{~A} / \mathrm{G})$ genotype had greater biological age as compared with carriers of other genotypes among patients with diagnosed CMP [4].

(c) Chernyak Yu.I., 2021

Yury I. Chernyak - Doctor of Biological Sciences, Leading researcher (e-mail: yuri_chernyak@hotmail.com; tel.: +7 (3955) 58-69-10, ext. 1412; ORCID: https://orcid.org/0000-0001-9641-0327). 
Damage to the brain was rather specific in patients with CMP; it attracted our attention to tumor necrosis factor TNF- $\alpha$ as a key inflammatory/immune response mediator [5]. TNF- $\alpha$ gene is among the most polymorphic genes of cytokines and, just as HSPA1 genes, is located in the locus of the major histocompatibility complex on the short arm of chromosome 6 . Giacconi et al. established a significant correlation between $1267 \mathrm{~A} / \mathrm{G}$ HSP70 polymorphism and TNF- $\alpha$ levels in blood plasma in healthy elderly people [6]. In particular, $\mathrm{G}$ allele carriers had elevated TNF- $\alpha$ level, and in authors' opinion, it indicated that this allele had anti-inflammatory properties. Upregulated HSP70 gene expression causes repression of lipopolysaccharides-induced TNF- $\alpha$ and IL-6 production thus induces protection against inflammation.

A significant increase in concentration of endogenous S100B protein in blood serum taken from patients with diagnosed CMP could characterize an extent to which a pathologic process as active [7]. S100B protein belonged to S100 super-family of calciumbinding proteins which expressed in various cells of the central nervous system and its elevated concentrations were detected, in particular, in patients suffering from Alzheimer and Parkinson disease [8,9]. Due to lack of protein specificity some researchers do not recommend to rely on its concentration when performing differential diagnostics in case a neurodegenerative disease is suspected in a patient. They also note that S100B protein has only limited utility when it comes to monitoring over disease progression [10]. A wide range of studies to assess the correlation between SNPs in the S100B gene and various diseases have been performed in recent years $[9,11,12]$.

Our research goal was to examine the association between polymorphisms of HSPA1B, $S 100 B$ and TNF genes with a risk that chronic mercury poisoning might occur.

Data and methods. To reveal any association between polymorphic variants of HSPA1B $\quad(+1267 \mathrm{~A} / \mathrm{G}, \quad$ rs1061581), TNF- $\alpha$ $(-308 \mathrm{G} / \mathrm{A}, \mathrm{rs} 1800629)$ and $\mathrm{S} 100 \mathrm{~B}(\mathrm{C} / \mathrm{T}, \mathrm{rs} 9722)$ genes and CMP development, we examined a cohort that was created in 2016 and then expanded later; it included 128 former workers who had previously been employed at caustic production and chronically exposed to mercury vapors [1]. All the examined workers were distributed into two groups; the group 1 included workers with long working experience who had no CMP $(n=46)$, and the group 2 was made up of patients in a longterm CMP period $(n=82)$. To assess how polymorphic locus of HSPA1B (+1267A/G) genotype was distributed in a regional subpopulation, we additionally examined 298 male workers (group 3) who were practically healthy and had no mercury exposure at their workplaces. Long-term clinical examinations among workers, mercury contents in biological substrates and contamination detected in working areas at caustic production had been generalized earlier [1].

All workers gave their written informed consent to take part in the research. Venous blood was taken into vacutainer tubes with $\mathrm{K}_{3}$ EDTA. The samples were then aliquoted and stored at $-70^{\circ} \mathrm{C}$. DNA was extracted with «DNA-express-blood-plus» reagent kit («Lytech», Russia); then PCR-RFLP analysis was performed. To accomplish genotyping (rs1061581 and rs1800629), we applied primers synthesized by «Medigen» (Novosibirsk, Russia) and «Evrogen» (Moscow, Russia), and endonucleases of PstI and TaaI restrictions produced by «Thermo Fisher Scientific» (Lithuania) accordingly. The structure of the primers and PCR conditions are described in details in the papers [13, 14]; rs9722 was examined with commercial kits produced by «Lytech»(Moscow, Russia). Electrophoresis was performed in $1.5 \%$ agarose gel (rs1061581 and rs 1800629 ) and $7.5 \%$ polyacrylamide gel (rs9722), and the results were estimated in transmitting UV-light after painting with ethdium bromide staining.

We performed the exact Fischer's test (two-tailed test) to assess differences in allele and genotype frequencies between groups using «STATISTICA 6.1» software package (StatSoft, USA). We used SNPStats package 
to verify with Hardy-Weinburg equilibrium $\left(\chi^{2}\right.$-test) and logistic regression in order to reveal a correlation between examined polymorphic loci and CMP for several genetic models [15]. Results obtained via regression analysis were presented as odds ratio (OR), $95 \%$ confidence interval $(95 \% \mathrm{CI})$ and the exact significance $p$.

Results and discussion. The genotype frequency distribution for examined polymerphisms in groups corresponded to HardyWeinburg equilibrium. We detected some differences in alleles and genotypes frequencies between the group 1 and the group 2 only for polymorphic variant of HSPA1B $(+1267 \mathrm{~A} / \mathrm{G})$ (Table 1). It was manifested by more frequent carriage of both rare $\mathrm{G}$ allele $(p=0.003)$ and rare GG homozygote $(p=0.005)$ in the group 1 against the group 2. $23.2 \%$ patients (19 out of 82) from the group 2 had GG genotype and $95 \%$ (19 out of 82) of its carriers were diagnosed with the had CMP. We should note that our research revealed only two carriers of a rare AA homozygote rs1800629 in the group 2 and there were no carriers of TT homozygote rs9722 in both examined groups.

Table 2 contains generalized results on how genotypes of polymorphic locus $+1267 \mathrm{~A} / \mathrm{G}$ in $H S P 1 A B$ gene were distributed among people in the examined groups. The results indicate that significant differences between the group 1 and the group 3 were revealed only for GG genotype carriers. We should note that there were no differences

Table 1

Allele frequencies and genotype distribution of $H S P 1 A B, T N F-\alpha$ and $S 100 B$ genes polymorphisms in groups

\begin{tabular}{|c|c|c|c|}
\hline $\begin{array}{l}\text { Gene (polymorphic locus), } \\
\text { allele and genotype }\end{array}$ & Group $1(n=46)$ & Group $2(n=82)$ & Fisher's exact test $(d f=2) *$ \\
\hline \multicolumn{4}{|l|}{ HSPA1B (rs1061581) } \\
\hline $\mathrm{A}$ & $68(0.74)$ & $90(0.55)$ & \multirow{2}{*}{0.003} \\
\hline $\mathrm{G}$ & $24(0.26)$ & $74(0.45)$ & \\
\hline $\mathrm{AA}$ & $23(0.5)$ & $27(0.33)$ & 0.062 \\
\hline $\mathrm{AG}$ & $22(0.48)$ & $36(0.44)$ & 0.714 \\
\hline GG & $1(0.02)$ & $19(0.23)$ & 0.005 \\
\hline \multicolumn{4}{|l|}{$T N F-\alpha(\mathrm{rs} 1800629)$} \\
\hline $\mathrm{G}$ & $78(0.85)$ & $146(0.89)$ & \multirow{2}{*}{0.331} \\
\hline A & $14(0.15)$ & $18(0.11)$ & \\
\hline $\mathrm{AA}$ & $0(0)$ & $2(0.02)$ & 0.536 \\
\hline $\mathrm{AG}$ & $14(0.3)$ & $14(0.17)$ & 0.118 \\
\hline GG & $32(0.7)$ & $66(0.8)$ & 0.194 \\
\hline \multicolumn{4}{|l|}{ S100B (rs9722) } \\
\hline $\mathrm{C}$ & $83(0.9)$ & $143(0.87)$ & \multirow{2}{*}{0.547} \\
\hline $\mathrm{T}$ & $9(0.1)$ & $21(0.13)$ & \\
\hline $\mathrm{CC}$ & $37(0.8)$ & $61(0.74)$ & \multirow{3}{*}{0.518} \\
\hline $\mathrm{CT}$ & $9(0.2)$ & $21(0.26)$ & \\
\hline TT & $0(0)$ & $0(0)$ & \\
\hline
\end{tabular}

$\mathrm{N}$ o t e : absolute values are presented (relative frequency); * comparison of group 1 and group 2.

Table 2

Genotype distribution of HSPA1B $(+1267 A>G)$ gene polymorphism in groups

\begin{tabular}{|c|c|c|c|c|c|}
\hline Genotype & Group 1 $(n=46)$ & Group 2 $(n=82)$ & Groups 1 and 2 $(n=128)$ & Group 3 $(n=298)$ & $p_{1} / p_{2} / p_{3}{ }^{*}$ \\
\hline AA & $23(0.5)$ & $27(0.33)$ & $50(0.39)$ & $109(0.36)$ & $0.103 / 0.604 / 0.663$ \\
\hline AG & $22(0.48)$ & $36(0.44)$ & $58(0.45)$ & $139(0.47)$ & $1.000 / 0.708 / 0.833$ \\
\hline GG & $1(0.02)$ & $19(0.23)$ & $20(0.16)$ & $50(0.17)$ & $0.006 / 0.197 / 0.887$ \\
\hline
\end{tabular}

$\mathrm{N}$ o t e : absolute values are presented (relative frequency); ${ }^{*} p_{1} / p_{2} / p_{3}$ is the Fischer's exact test $(d f=2)$ when groups 1, 2 and 1+2 were compared with group 3 respectively. 
in frequency of genotype carriage (GG included) when workers who were chronically exposed to mercury poisoning (groups 1 and 2) were compared with the male subpopulation (group 3).

In our discussion on how genotypes of the examined polymorphic loci are distributed we should note that frequency of GG- HSP $1 A B$ $(+1267 \mathrm{~A} / \mathrm{G})$ genotype was comparable both in the combined group and the group 3 (0.16 and 0.17 accordingly) with the same parameter detected for a Polish cohort (0.17) [6]. It is also interesting to note that frequency of the said genotype was somewhat lower in all the above mentioned groups than in the group $2(0.23)$. As for a rare homozygote AA-TNF- $\alpha$ $(-308 \mathrm{G} / \mathrm{A})$ (there were only two people who carried it among patients with CMP), its frequency was a bit higher in the group $2(0.02)$ than the same parameter in an Italian and Greek selections (0.009 and 0.014) but lower than in German, French, and Polish selections (0.027, 0.029 and 0.031 respectively) [6]. Unfortunately, we did not reveal any TT-S100B $(\mathrm{C} / \mathrm{T}, \mathrm{rs} 9722)$ homozygote carriers in the examined cohort. As it has been pointed out in literature, the named genotype is rather rare. In particular, its frequency amounted to 0.010 and 0.013 for two control cohorts in a Swedish study (421 and 372 people; 4 and 5 carriers respectively) [9]. However, frequency of this rare TT homozygote was significantly higher among patients with depression in China and amounted to 0.15 [16]. We can assume that in the latter case elevated frequency of the named genotype was caused not only by an association with the examined disease but also examined people belonging to another race, namely Mongoloid one.

Table 3 contains results obtained via logistic regression for basic genetic models. When it comes to HSP1AB $(+1267 \mathrm{~A} / \mathrm{G})$ locus, the analysis revealed that a homozygous as per rare allele GG genotype is associated with a risk of CMP development (recessive model, $\mathrm{OR}=13.57(p<0.0001) ;$ additive model, $\mathrm{OR}=2.32(p=0.0026))$. And lower value of Akaike information criterion for the recessive model (AIC $=158.6$ ) indicates that it is more relevant than the additive one (AIC $=162.1$ ). We should also note that our analysis of models built for rs1800629 and rs9722 polymorphisms didn't reveal any significant associations with CMP. We analyzed only a codominant model $(\mathrm{CC} / \mathrm{CT})$ for $S 100 \mathrm{~B}(\mathrm{C} / \mathrm{T}$, rs9722) locus due to carriers of rare TT homozygote being absent in the examined groups. Genetic models that were adjusted for duration of mercury vapor exposure did not reveal more significant association with CMP.

The next stage in our study involved analyzing haplotypes for four possible allele combinations of HSPA1B $(+1267 \mathrm{~A} / \mathrm{G})$ and TNF- $\alpha$ $(-308 \mathrm{G} / \mathrm{A})$ loci (Table 4$)$. We revealed a significant 2.6 times increase in OR for CMP development only for $\mathrm{G}-\mathrm{G}$ haplotype $(\mathrm{OR}=2.6$, CI $1.27-5.32, p=0.0098)$. The significance this haplotype has seems logical since G-HSPA1B $(+1267 \mathrm{~A} / \mathrm{G})$ and G-TNF- $\alpha$ $(-308 \mathrm{G} / \mathrm{A})$ alleles correlate with producing

Table 3

Association of the examined polymorphic loci of HSP1AB, TNF- $\alpha$ and S100B genes with CMP development

\begin{tabular}{|c|c|c|c|c|}
\hline $\begin{array}{c}\text { Gene } \\
\text { (polymorphic locus) }\end{array}$ & Rare allele & Model & OR $(95 \%$ CI $), p$ & AIC \\
\hline HSPA1B (rs1061581) & G & $\begin{array}{l}\text { AA/AG-GG } \\
\text { AA-AG/GG } \\
\text { AA-AG-GG }\end{array}$ & $\begin{array}{c}2.04(0.97-4.27), 0.58 \\
13.57(1.75-105.09), 0.0004 \\
2.32(1.31-4.12), 0.0026\end{array}$ & $\begin{array}{l}167.6 \\
158.6 \\
162.1\end{array}$ \\
\hline$T N F-\alpha(\operatorname{rs} 1800629)$ & A & $\begin{array}{l}\text { GG/GA-AA } \\
\text { GG-GA/AA } \\
\text { GG-GA-AA }\end{array}$ & $\begin{array}{c}0.55(0.24-1.57), 0.17 \\
\text { NA (0.00-NA), } 0.18 \\
0.69(0.32-1.46), 0.43\end{array}$ & $\begin{array}{l}169.3 \\
169.4 \\
170.2 \\
\end{array}$ \\
\hline S100B (rs9722) * & $\mathrm{T}$ & $\mathrm{CC} / \mathrm{CT}$ & $1.42(0.59-3.42), 0.43$ & 170.6 \\
\hline
\end{tabular}

$\mathrm{N}$ o t e : results of logistic regression for three genetic models (top-down): dominant, recessive, and additive; NA - not defined; * codominant model; AIC is a value of Akaike information criterion. 
Table 4

Haplotype frequencies of the examined $H S P 1 A B$ and TNF- $\alpha$ polymorphisms, $n=128$

\begin{tabular}{|c|c|c|c|c|c|}
\hline Haplotype & $\begin{array}{c}\text { HSPA1B } \\
(+1267 \mathrm{~A} / \mathrm{G})\end{array}$ & $\begin{array}{c}\text { TNF- } \alpha \\
(-308 \mathrm{G} / \mathrm{A})\end{array}$ & Frequency & OR (95\% CI) & $p$ \\
\hline 1 & $\mathrm{~A}$ & $\mathrm{G}$ & 0.5447 & 1.00 & - \\
\hline 2 & $\mathrm{G}$ & $\mathrm{G}$ & 0.3003 & $2.6(1.27-5.32)$ & 0.0098 \\
\hline 3 & $\mathrm{G}$ & $\mathrm{A}$ & 0.0825 & $1.32(0.45-3.89)$ & 0.61 \\
\hline 4 & $\mathrm{~A}$ & $\mathrm{~A}$ & 0.0425 & $0.38(0.07-2.05)$ & 0.26 \\
\hline
\end{tabular}

elevated and reduced HSP70 and TNF- $\alpha$ contents respectively [6]. Besides, we detected a significant $(p=0.0004)$ linkage disequilibrium $D^{\prime}=0.459$ between polymorphic rs1061581 and rs1800629 loci. Such data indicate genetic interaction between HSPA1B $(+1267 \mathrm{~A} / \mathrm{G})$ and TNF- $\alpha(-308 \mathrm{G} / \mathrm{A})$ loci in the examined cohort.

We expanded our previously crated cohort via including eight patients with diagnosed CMP into it; three of them carried GGHSPA1B (1267A/G) genotype. It confirmed that our conclusions made in the previous study were substantiated [1]. Besides, we established in the present work that there were no differences in genotypes distribution among the occupational cohort (groups 1 and 2) in comparison with the subpopulation (group 3). It allows us to assume that our results can hardly turn out to be false-positive in spite of our sampling of the examined workers being rather small. We should also note that we assessed polymorphic variants of HSPA1B, TNF$\alpha$ and $S 100 B$ genes in our research taking them as gene-candidates; there are no data on these genes in the latest specialized reviews that focus on genetic aspects of sensitivity to effects produced by mercury $[17,18]$.

By now there is general awareness that a significant role belongs to genetic variants and gene polymorphisms being able to modify mercury neurotoxicity in occupational groups running combined occupational and ecological health risks [19]. Recent studies have shown that non-organic mercury depos- its in brain tissues of people who have been exposed to environmental contamination are different from those detected in people who have undergone acute or chronic exposure to high mercury concentrations at their workplaces [20]. Overall, it calls for examining workers' genetic status in order to reveal people who are hypersensitive to the toxicant and who can suffer severe damage even when they are exposed to its relatively small concentrations [19]. It seems relevant if such approaches will be implemented for liquidators involved in eliminating accumulated contamination at the industrial area belonging to the former «Usolyekhimprom» LLC where the surface mounted part of most hazardous object, namely a mercury electrolysis workshop, has just been dismantled.

Conclusions. Results obtained in the present study allow concluding that carriers of homozygote for the rare allele GG-HSPA1B $(+1267 \mathrm{~A} / \mathrm{G})$ genotype have a high prognostic CMP risk.

Acknowledgement. The author is grateful to Alla P. Merinova for technical assistance; to doctors of the Clinic for organizing medical examinations and creating groups for the research

Funding. The work was supported within a framework of State Task for the East-Siberian Institute of Medical and Ecological Research (№ 0534-2016-0006).

Conflict of interests. The author declares there is no any conflict of interests.

\section{References}

1. Chernyak Yu.I., Merinova A.P. HSP70 (HSPA1) polymorphisms in former workers with chronic mercury vapor exposure. International Journal of Occupational Medicine and Environmental Health, 2017, vol. 30, no. 1, pp. 77-85. DOI: 10.13075/ijomeh.1896.00732 
2. Lakhman O.L., Katamanova E.V., Konstantinova T.N., Shevchenko O.I., Meshcheryagin V.A., Andreeva O.I., Rusanova D.V., Sudakova N.G. Contemporary approaches to the classification of occupational mercury intoxication. Ekologiya cheloveka, 2009, no. 12, pp. 22-27 (in Russian).

3. Turturici G., Sconzo G., Geraci F. Hsp70 and its molecular role in nervous system diseases. Biochemistry Research International, 2011, vol. 2011, pp. e618127. DOI: 10.1155/2011/618127

4. Chernyak Yu.I., Shevchenko O.I., Lakhman O.L. Polymorphic loci of HSP1A genes and biological age in workers chronically exposed to mercury vapor. Meditsina truda i promyshlennaya ekologiya, 2017, no. 10, pp. 38-42 (in Russian).

5. Williams L.M., Lali F., Willetts K., Balague C., Godessart N., Brennan F., Feldmann M., Foxwell B.M.J. Rac mediates TNF-induced cytokine production via modulation of NF-kappa B. Molecular Immunology, 2008, vol. 45, no. 9, pp. 2446-2454. DOI: 10.1016/j.molimm.2007.12.011

6. Giacconi R., Costarelli L., Malavolta M., Piacenza F., Galeazzi R., Gasparini N., Basso A., Mariani E. [et al.]. Association among 1267 A/G HSP70-2, -308 G/A TNF-a polymorphisms and pro-inflammatory plasma mediators in old ZincAge population. Biogerontology, 2014, vol. 15, no. 1, pp. 65-79. DOI: 10.1007/s10522-013-9480-1

7. Boklazhenko E.V., Bodienkova G.M. Level alterations in protein S-100B in blood sera of employees exposed to mercury. Byulleten' VSNTS SO RAMN, 2010, no. 1 (71), pp. 14-16 (in Russian).

8. Griffin W.S., Stanley L.C., Ling C., White L., MacLeod V., Perrot L.J., White 3rd C.L., Araoz C. Brain interleukin 1 and S-100 immunoreactivity are elevated in Down syndrome and Alzheimer disease. Proceedings of the National Academy of Sciences of the United States of America, 1989, vol. 86, no. 19, pp. 7611-7615. DOI: 10.1073/pnas.86.19.7611

9. Fardell C., Zettergren A., Ran C., Belin A.C., Ekman A., Sydow O., Bäckman L., Holmberg B. [et al.]. S100B polymorphisms are associated with age of onset of Parkinson's disease. BMC Medical Genetics, 2018, vol. 19, no. 1, pp. e42. DOI: 10.1186/s12881-018-0547-3

10. Steiner J., Bogerts B., Schroeter M.L., Bernstein H.G. S100B protein in neurodegenerative disorders. Clinical Chemistry and Laboratory Medicine, 2011, vol. 49, no. 3, pp. 409-424. DOI: 10.1515/CCLM.2011.083

11. Zhai J., Cheng L., Dong J., Shen Q., Zhang Q., Chen M., Gao L., Chen X. [et al.]. S100B gene polymorphisms predict prefrontal spatial function in both schizophrenia patients and healthy individuals. Schizophrenia Research, 2012, vol. 134, no. 1, pp. 89-94. DOI: 10.1016/j.schres.2011.09.029

12. Chen Y., Chen X., Yao M., Chen L., Chen W., Liu X. Association of S100B 3'UTR polymorphism with risk of chronic heart failure in a Chinese Han population. Medicine (Baltimore), 2020, vol. 99, no. 26, pp. e21018. DOI: 10.1097/MD.0000000000021018

13. Li J.X., Tang B.P., Sun H.P., Feng M., Cheng Z.H., Niu W.Q. Interacting contribution of the five polymorphisms in three genes of Hsp70 family to essential hypertension in Uygur ethnicity. Cell. Stress Chaperones., 2009, vol. 14, no. 4, pp. 355-362. DOI: 10.1007/s12192-008-0089-2

14. Yang K., Xie G.R., Hu Y.Q., Mao F.Q., Su L.Y. Association study of astrocyte-derived protein S100B gene polymorphisms with major depressive disorder in Chinese people. The Canadian Journal of Psychiatry, 2009, vol. 54, no. 5, pp. 312-319. DOI: 10.1177/070674370905400505

15. Solé X., Guinó E., Valls J., Iniesta R., Moreno V. SNPStats: A web tool for the analysis of association studies. Bioinformatics 2006, vol. 1, no. 22 (15), pp. 1928-1929. DOI: 10.1093/bioinformatics/bt1268

16. Yang K., Hu Y.Q., Xie G.R., Mao F.Q., Su L.Y. No association of the rs $9722 \mathrm{C}>\mathrm{T}$ in the S100B gene and susceptibility to major depression in a Chinese population. Genetic Testing 2008, vol. 12 , no. 4, pp. 487-489. DOI: $10.1089 /$ gte.2008.0023

17. Gundacker C., Gencik M., Hengstschläger M. The relevance of the individual genetic background for the toxicokinetics of two significant neurodevelopmental toxicants: mercury and lead. Mutation Research 2010, vol. 705, no. 2, pp. 130-140. DOI: 10.1016/j.mrrev.2010.06.003

18. Andreoli V., Sprovieri F. Genetic aspects of susceptibility to mercury toxicity: An overview. International Journal of Environmental Research and Public Health, 2017, vol. 14, no. 1, pp. e93. DOI: 10.3390/ijerph14010093

19. Chirico F., Scoditti E., Viora C., Magnavita N. How occupational mercury neurotoxicity is affected by genetic factors. A systematic review. Applied Sciences, 2020, vol. 10, no. 21, pp. e7706. DOI: $10.3390 /$ app 10217706 
20. O’Donoghuea J.L., Watsona G.E., Brewere R., Zarebaa G., Etof K., H. Takahashig, Marumotoh M., Lovei T. [et al.]. Neuropathology associated with exposure to different concentrations and species of mercury: A review of autopsy cases and the literature. Neuro Toxicology, 2020, no. 78 , pp. 88-98. DOI: 10.1016/j.neuro.2020.02.011

Chernyak Yu.I. Association between HSPA1B, S100B, and TNF- $\alpha$ gene polymorphisms and risks of chronic mercury poisoning. Health Risk Analysis, 2021, no. 1, pp.126-132. DOI: 10.21668/health.risk/2021.1.13.eng

Received: 17.11 .2020

Accepted: 03.03.2021

Published: 31.03 .2021 
UDC 612.17

DOI: 10.21668/health.risk/2021.1.14.eng

Research article

\title{
COMBINATION OF HLA-DRB1 ALLELES AS A FACTOR CAUSING RISKS OF SPORADIC CONGENITAL HEART DEFECTS AND CONGENITAL MALFORMATIONS WITHOUT CHROMOSOME DISEASES
}

\author{
A.V. Shabaldin ${ }^{1,2}$, A.V. Tsepokina ${ }^{1}$, O.V. Dolgikh ${ }^{3}$, E.V. Shabaldina ${ }^{2}$, A.V. Ponasenko ${ }^{1}$ \\ ${ }^{1}$ Scientific Research Institute for Complex Issues of Cardiovascular Diseases, 6 Sosnovyi Blvd., Kemerovo, \\ 650002, Russian Federation \\ ${ }^{2}$ Kemerovo State Medical University, 22a Voroshilova Str., Kemerovo, 650056, Russian Federation \\ ${ }^{3}$ Federal Scientific Center for Medical and Preventive Health Risk Management Technologies, 82 Monastyrskaya \\ Str., Perm, 614045, Russian Federation
}

Congenital heart defects are anomalies that are becoming more and more frequent every year. Their specific weight is the highest among all the defects and malformations in fetus. Besides, children with sporadic congenital heart defects and malformations are still born rather frequently. We made an assumption that congenital heart defects (CHD) and congenital malformations (CM) were formed due to inflammatory process decompensation within «mother - fetus» system occurring in case of a conflict as per HLA between a semi-allogenic fetus and its mother's microenvironment. A risk of such a conflict might be associated with certain HLA combinations in parents' genotypes.

Our research goal was to reveal peculiarities of HLA-DRB1 alleles combinations in married couples who had children with sporadic CHD and CM without any chromosome diseases and to determine whether such peculiarities could cause risks of congenital anomalies.

We determined frequency of 14 alleles in HLA-DRB1 gene in all people who took part in the research.

Our research allowed establishing that parents whose children suffered from CHD more frequently had common $H L A-D R B 1 * 04$, female HLA-DRB1*07 with male HLA-DRB1*13, HLA-DRB1*17 and female HLA-DRB1*13 with male $H L A-D R B 1 * 14$. Children who suffered from CM more frequently had parents who were homologous as per HLA-DRB1*12, as well as with female HLA-DRB1*12 and male HLA-DRB1*01, HLA-DRB1*04, HLA-DRB1*13, and HLA-DRB1*15; this greater frequency was statistically significant. We also detected an authentic increase in frequency of HLA-DRB1*12 allele in children against their parents. Children with CM also had HLA-DRB1*12 allele statistically significantly more frequently than healthy children.

Peculiarities related to HLA-DRB1 alleles combination are genetic predictors of CHD and CM occurrence; their determination will allow minimizing risks of such disorders due to early diagnostics and timely prevention.

Key words: major histocompatibility complex, HLA-DRB1, alleles, congenital heart diseases, congenital malformations, risk factor, married couples, spouse compatibility.

The major histocompatibility complex (HLA in a human body) is a vital component in the immune systems of mammals (and people as well). A set of genes that are included into HLA is localized as per three classes (I, II, and III). The class II contains HLA-DR and HLA-DQ loci with their genes coding molecules that present endo- and exo-antigens to T-helper lymphocytes (of the 1,2, 3, 17 and 22 types). Through this phenomenon, they de-

(C) Shabaldin A.V., Tsepokina A.V., Dolgikh O.V., Shabaldina E.V., Ponasenko A.V., 2021

Andrey V. Shabaldin - Doctor of Medical Sciences, Associate Professor, Leading researcher at the Heart Defects Laboratory; Professor at the Department for Microbiology, Immunology, and Virology (e-mail: weit2007@yandex.ru; tel.: +7 (903) 907-51-97; ORCID: https://orcid.org/0000-0002-8785-7896).

Anna V. Tsepokina - Junior researcher at the Genome Medicine Laboratory (cepoav1991@gmail.com; tel.: +7 (950) 586-33-97; ORCID: https://orcid.org/0000-0002-4467-8732).

Elena V. Shabaldina - Doctor of Medical Sciences, Associate Professor, Head of the Otorhinolaryngology Department (e-mail: weit2007@yandex.ru; tel.: +7 (951) 163-90-11; ORCID: https://orcid.org/0000-0002-0450-2767).

Oleg V. Dolgikh - Doctor of Medical Sciences, Professor, Head of the Department for Immune-Biological Diagnostic Procedures (e-mail: oleg@fcrisk.ru; tel.: +7 (342) 236-39-30; ORCID: http://orcid.org/0000-0003-4860-3145).

Anastasia V. Ponasenko - Candidate of Medical Sciences, Head of the Genome Medicine Laboratory (e-mail: ponaav@kemcardio.ru; tel.: +7 (951) 591-05-50; ORCID: https://orcid.org/0000-0002-3002-2863). 
termine power and quality of immune responses to macro- and micro-ecology antigens [1]. Genes belonging to HLA I and II classes are highly polymorphic. Thus, according to HLA Alleles Numbers ${ }^{1}$ there are more than 2,500 alleles described at the moment for HLA-DRB1 only. HLA-DRB1*01, HLA-DRB1*03 (17), HLADRB1*04, HLA-DRB1*07, HLA-DRB1*11, HLA-DRB1*12, HLA-DRB1*13 and HLA$D R B 1 * 15$ alleles are evenly distributed within populations in the world [2-4]. It was revealed that alleles included into $H L A-D R B 1 * 03$ (17), HLA-DRB1*04, HLA-DRB1*05(11), and HLA$D R B 1 * 15$ groups had certain associations with immune system pathologies and reproductive losses $[5,6]$. It is assumed that there are several selective mechanisms in populations that are responsible for imposing limits on random inheritance and for controlling "pathologic» alleles within this or that population. Such selective mechanisms include, for example, negative-assortative mating, selection at gametogenesis level, selection in interactions as per HLA between a mother and a semi-allogenic embryo/fetus, as well as intensity of resistance or sensitivity to infectious and parasitic agents [7]. Let us note that ontogenesis gives this exact order of selection mechanisms.

Congenital heart diseases (CHDs) are a topical issue for public healthcare since their frequency is growing and they account for the biggest share among all malformations and development anomalies [8, 9]. Besides, children with sporadic congenital malformations and development anomalies (CMDAs) without any chromosome diseases are still born rather frequently. There is a well-grounded assumption that CHDs and CMDAs occur, among other things, due to decompensation with an inflammatory process within «mother - fetus» system that develops in case there is a conflict as per HLA between a semi-allogenic fetus and micro-environment inside a mother's body $[10,11]$. A risk of such a conflict can be associated with certain HLA combinations in parents' genotypes.

Bearing in mind that an association between certain alleles and HLA genotypes and immune-inflammatory diseases and reproductive losses, including congenital fetus/embryo malformations, has been proven [12, 13], we believe that a study on peculiarities of alleles belonging to a gene in the major histocompatibility complex (HLA) will allow determining how compatible parents are, hence, it will provide an opportunity to estimate a risk that a child will be born with congenital malformations and development anomalies thus resulting in reproductive losses.

Given that, our research goal was to determine peculiarities of HLA-DRB1 allele combinations in families who had children with sporadic congenital heart diseases and congenital malformations without chromosome diseases as well as a nature of their inheritance by these children.

Data and methods. Our research was accomplished at the Scientific Research Institute for Complex Issues of Cardiovascular Diseases, Kemerovo State Medical University and Kemerovo State University. The research was approved by the local ethical committee at the Scientific Research Institute for Complex Issues of Cardiovascular Diseases. All the participants gave their informed written consent to take part in the research.

The first test group was made up of 48 families with children in them (23 boys and 25 girls) being born with congenital heart diseases regardless of any chromosome disease. We examined case histories in this group and revealed that there were no congenital heart diseases either in mother's or father's ancestors. HLA-DRB1 allele combinations were calculated in families both regarding female alleles meeting with male ones and vice versa. Overall, we analyzed 384 combinations $(48 \cdot 8=384)$. This test group was created at the Scientific Research Institute for Complex Issues of Cardiovascular Diseases and the Kemerovo State Medical University.

The second test group consisted of 68 families with children having congenital malformations and development anomalies (CMDAs) without chromosome diseases. There were no

\footnotetext{
${ }^{1}$ HLA Alleles Numbers. Nomenclature. Available at: http://hla.alleles.org/nomenclature/stats.html (12.06.2020) (in Russian).
} 
children with CHDs in this group. All congenital malformations were sporadic without any traces in family case history. These malformations included the following: 25 children had III-IV degree hydrocephaly; 16 children, vascular plexus cysts; 114 children, hydronephrosis II; 5 children, Arnold-Chiari malformation; 5 children, vermis agenesis; and 3 children, one kidney agenesis. HLA-DRB1 allele combinations were analyzed in the same manner and totally we detected 544 combinations $(68 \cdot 8=544)$. This group was created at clinics within the $\mathrm{Ke}$ merovo State Medical University system.

Our reference group included 132 families who had two or more healthy children. 1,056 combinations were detected in this group $(132 \cdot 8=1,056)$; the group was created at ambulatories and polyclinics within the Kemerovo State Medical University system.

Additionally, 51 girls and 89 boys were examined at the Biological Faculty of the Kemerovo State University; they were all in their reproductive age and there were no blood relatives or married couples among them. These young people took part in an experiment entitled «HLA-associated olfactory selection». The research was approved by the local ethical committee at the Kemerovo State University and all people who took part in it gave their informed written consent. This group was used in the present research for calculating a probability that female and male $H L A-D R B 1$ alleles would meet in a reproductive population (random selection). This probability was calculated via multiplying a selected female allele by all male alleles in turn and vice versa. The calculation was performed for all female and male alleles. When transforming share values into absolute ones, we used an overall number of all possible combinations that was equal to $18,156(51 \cdot 89 \cdot 4=18,156)$.

Our research object was genome DNA extracted from peripheral blood leucocytes via phenol-chloroform extraction as per a conventional procedure. HLA-DRB1 typing was performed via PCR taking into account results obtained in real time mode with DT-96 detecting amplifier (DNA-technology, Russia). We determined frequency of 14 HLA-DRB1 gene alleles with commercial reagent sets HLADNA-TEX (Catalogue number R1-H001-S3/5, DNA-technology, Russia).

Research procedure. At the first stage in our research we compared frequencies of actual HLA-DRB1 allele combinations in the reference group and calculated combinations obtained for young males and females who were not blood relatives. Calculated combinations were also compared with actual HLA-DRB1 allele combinations in both test groups. Then we compared frequencies of HLA-DRB1 allele combinations in the reference group and two test ones. In addition, we compared frequencies of HLA-DRB1 allele combinations in families who had children with CHDs and those with children who had CMDAs.

At the next stage we analyzed how children inherited alleles from their parents in two test groups and the reference one. In the reference group we examined inheritance by healthy children, and in test groups, by children with CHDs and CMDAs respectively. For each HLA-DRB1 we took into account alleles that were inherited by children from mothers, fathers or both parents. If inheritance is equiprobable, there shouldn't be any significant differences between inherited and non-inherited alleles and delta between them should tend to zero. The first stage in the research focused on determining peculiarities of HLA assortativity in case a fetus was healthy and in case there was congenital fetus pathology. The second stage concentrated on revealing pre-natal selection, including gametogenesis and interaction as per HLA within «mother - fetus» system in case a fetus was healthy and in case congenital fetus malformation occurred.

All the data were mathematically processed with STATISTICA 8.0 (Stat Soft Inc., USA). Hardy-Weinburg equilibrium was determined with Pearson's chi-square. Expected frequencies (in shares) of allele combinations in case of random selection between people with different sexes were calculated via multiplying frequencies (in shares) of respective female alleles with male ones. Expected homozygocity was calculated via squaring a 
share of a respective allele. To reveal differences in frequencies of allele combinations in the examined groups and in inheritance from mothers to children, we used Pearson's chisquare with Yates's correction for continuity. To assess risks of a congenital heart disease, we calculated odds ratio $(O R)$ and its $95 \%$ confidence interval $(C I)$. Differences were considered statistically significant in all cases when $p<0.05$ [14].

Results and discussion. Our research revealed that there were no statistically significant differences between HLA-DRB1 genotype frequency and frequency of genotypes calculated with Hardy-Weinburg equilibrium.

Data given in Table 1 show that there were no differences in HLA-DRB1 alleles frequency between the group made up of young males and females where random allele combinations were estimated, and all the other groups made up of families; it indicates that the examined groups were comparable in terms of allele combinations.

We determined that frequency of HLA$D R B 1 * 12$ allele was higher among parents who had children with CMDAs against the reference group. Besides, this allele was more frequent in families who had children with CMDAs. We didn't detect any other statistically significant differences.

Then, according to the research procedure, we compared actual HLA-DRB1 allele combinations in the reference group and both test groups with calculated combinations obtained for young males and females who were not married or blood relatives (random selection). We revealed certain statistically significant differences that are given in Table 2.

Data given in Table 2 indicate that actual frequencies of allele combinations in families with healthy children were different from calculated ones (random selection) predominantly as per $H L A-D R B 1 * 01$ and $H L A-D R B 1 * 15$. Besides, positive selection involves a growing number of families with female and male HLA-DRB1*01, HLA-DRB1*15, HLA-DRB1*07 and HLA-DRB1*03(17), HLA-DRB1*4, HLA$D R B 1 * 15$ accordingly.

We analyzed deviations from random selection in families where children suffered from either CMDAs or CHDs; our analysis revealed the following. Only positive selection was detected in families where children had CMDAs and this selection involved married couples with female and male HLA$D R B 1 * 12$, as well as with female $H L A$ $D R B 1 * 12$ and male HLA-DRB $1 * 01, H L A-$ $D R B 1 * 04, \quad H L A-D R B 1 * 13, H L A-D R B 1 * 15$. Besides, just as it was the case with the reference group, there was positive selection in this group regarding a combination of female $H L A-D R B 1 * 07$ and male $H L A-D R B 1 * 15$ in a married couple.

Table 1

Distribution of $H L A-D R B 1$ alleles in the examined groups (\%)

\begin{tabular}{|c|c|c|c|c|c|}
\hline Alleles & 1. Random selection $(n=280)$ & 2. Reference $(n=528)$ & 3. CMDAs $(n=134)$ & 4. CHDs $(n=192)$ & $p$ \\
\hline 01 & 21.78 & 14.39 & 13.80 & 12.13 & 0.05 \\
\hline $03(17)$ & 7.85 & 9.47 & 2.23 & 10.46 & 0.05 \\
\hline 04 & 9.64 & 11.93 & 7.46 & 13.38 & 0.05 \\
\hline 07 & 7.50 & 9.28 & 10.07 & 11.29 & 0.05 \\
\hline 08 & 5.35 & 6.43 & 2.98 & 2.92 & 0.05 \\
\hline 09 & 0.71 & 4.16 & 1.86 & 0.83 & 0.05 \\
\hline 10 & 0.71 & 0.18 & 0.74 & 2.09 & 0.05 \\
\hline 11 & 11.42 & 10.98 & 15.67 & 15.48 & 0.05 \\
\hline 12 & 5.71 & 5.49 & 13.06 & 2.09 & $p_{2.3}=0.003$. \\
\hline 13 & 13.92 & 9.84 & 14.55 & 13.38 & 0.0007 \\
\hline 14 & 1.42 & 2.84 & 2.23 & 2.09 & 0.05 \\
\hline 15 & 11.07 & 11.74 & 14.17 & 13.80 & 0.05 \\
\hline 16 & 2.85 & 3.22 & 1.11 & 0.00 & 0.05 \\
\hline
\end{tabular}


Allele combinations in the randomly selected group (calculated values) and in married couples in the reference and test groups (only statistically significant differences, \%)

\begin{tabular}{|c|c|c|c|}
\hline A combination of a female /male allele & Random selection, $n=18,156$ & Reference, CMDAs, CHDs & $p$ \\
\hline \multicolumn{5}{|c|}{ Reference, $n=1,056$} \\
\hline $01 / 01$ & 4.73 & $1.52(-)$ & 0.01 \\
\hline $01 / 15$ & 2.15 & $5.21(+)$ & 0.008 \\
\hline $03(17) / 15$ & 0.94 & $3.03(+)$ & 0.007 \\
\hline $07 / 15$ & 0.61 & $2.75(+)$ & 0.004 \\
\hline $15 / 01$ & 2.54 & $5.41(+)$ & 0.009 \\
\hline $15 / 03(17)$ & 0.58 & $2.75(+)$ & 0.003 \\
\hline $15 / 04$ & 1.04 & $3.69(+)$ & 0.005 \\
\hline $15 / 15$ & 1.16 & $8.62(+)$ & 0.0001 \\
\hline \multicolumn{5}{|c|}{ CMDAs, $n=544$} & $2.57(+)$ & 0.006 \\
\hline $07 / 15$ & 0.61 & $2.39(+)$ & 0.004 \\
\hline $12 / 01$ & 0.48 & $1.47(+)$ & 0.003 \\
\hline $12 / 04$ & 0.21 & $4.41(+)$ & 0.001 \\
\hline $12 / 12$ & 0.26 & $1.84(+)$ & 0.002 \\
\hline $12 / 13$ & 0.29 & $2.21(+)$ & 0.001 \\
\hline $12 / 15$ & 0.22 & $2.64(+)$ & 0.03 \\
\hline \multicolumn{5}{|c|}{ CHDs, $n=384$} & $1.44(+)$ & 0.01 \\
\hline $04 / 04$ & 0.89 & $2.41(+)$ & 0.03 \\
\hline $07 / 03(17)$ & 0.31 & $1.44(+)$ & 0.008 \\
\hline $13 / 14$ & 0.79 &
\end{tabular}

$\mathrm{N}$ o t e : / is an allele combination given as follows: the first allele is a female one, the second, male. Signs (-) and $(+)$ indicate either negative or positive selection.

Results in families with children suffering from sporadic CHDs without chromosome diseases also deviated from random selection as there was positive selection for female and male allele $H L A-D R B 1 * 04$. Other significant differences from the reference group were detected in this group regarding frequency of allele combinations for female $H L A-D R B 1 * 07$ and male $H L A-D R B 1 * 03, H L A-D R B 1 * 13$ as well as female HLA-DRB1*13 and male HLA-DRB1*14.

The most significant differences between the reference group and the groups with CMDAs and CHDs were detected when frequencies of allele combinations were compared. As it is shown in Table 3, family homology as per $H L A-D R B 1 * 12$ was more frequent in families having children with CMDAs against the reference group, and homology as per HLA$D R B 1 * 15$ was less frequent.

These data indicate that $H L A-D R B 1 * 12$ allele might be a marker for a cohort with
CMDAs. It is quite possible that these peculiarities are related to a deviation from physiological assortativity as per $H L A-D R B 1 * 12$ when a new married couple is created and it happens among other things, due to impacts exerted by social, economic, macro- and micro-ecological factors.

Just as it was the case with families where children had CMDAs, negative selection was detected in the group where children had CNDs for female and male HLA-DRB $1 * 15$ and additionally for female $H L A-D R B 1 * 13$ and male HLA-DRB1*15. Female HLA$D R B 1 * 03(17), H L A-D R B 1 * 13$ and male HLA$D R B 1 * 04$ and $H L A-D R B 1 * 07$ respectively were more frequent in married couples in this group than in the reference one. One can see from the table that male alleles $H L A-D R B 1 * 04$ and $H L A-D R B 1 * 07$ were more frequent in married couples both in the group with CMDAs and with CHDs than in the reference 
Table 3

Allele combinations in families with healthy children and in families with children suffering from congenital malformations and development anomalies and congenital heart diseases

(only significant differences are given, \%)

\begin{tabular}{|c|c|c|c|}
\hline A combination of a female /male allele & Reference, $n=1,056$ & CMDAs, CHDs & $p$ \\
\hline \multicolumn{3}{|c|}{ CMDAs, $n=544$} \\
\hline $12 / 07$ & 0.27 & $2.21(+)$ & 0.02 \\
\hline $12 / 12$ & 0.82 & $4.41(+)$ & 0.009 \\
\hline $13 / 07$ & 0.27 & $3.68(+)$ & 0.01 \\
\hline $15 / 04$ & 3.69 & $0.37(-)$ & 0.008 \\
\hline $15 / 15$ & 8.62 & 0.001 \\
\hline \multicolumn{4}{|c|}{ CHDs, $n=384$} \\
\hline $3(17) / 04$ & 0.19 & $1.1(-)$ & 0.03 \\
\hline $13 / 07$ & 0.27 & $2.88(+)$ & 0.01 \\
\hline $13 / 15$ & 4.67 & $0.96(-)$ & 0.02 \\
\hline $15 / 15$ & 8.62 & $1.68(-)$ & 0.009 \\
\hline \multicolumn{7}{|c|}{ CMDA,,$n=544$} & 0.24 & 0.01 \\
\hline $12 / 12$ & $4.41(+)$ & $0.88(+)$ & 0.03 \\
\hline
\end{tabular}

$\mathrm{N}$ o t e : / is an allele combination given as follows: the first allele is a female one, the second, male. Signs (-) and $(+)$ indicate either negative or positive selection.

one. Special attention should be paid to positive selection of a family $H L A-D R B 1 * 17$ and $H L A-D R B 1 * 04$ allele combination in the group with children suffering from CHDs. This heterozygote type, just as HLA-DRB $1 * 04$, $H L A-D R B 1 * 03(17)$ alleles separately, is associated with multiple autoimmune diseases including insulin-dependent pancreatic diabetes $[15,16]$. Therefore, deviations occurring in the test groups when selection is taking place may create preconditions for immune-inflammatory pathology including reproductive disorders.

Having compared two test groups, with CMDAs and CHDs, we revealed that HLADRB1*12, HLA-DRB1*15 u HLA-DRB1*07 alleles were differentiating markers between them. Family homology as per HLA-DRB $1 * 12$ created statistically significant difference between CVDAs and CHDs groups.

Deviations from random HLA-DRB1 combinations in married couples and further euqiprobable inheritance can influence HLA$D R B 1$ allele distribution among healthy and sick children. We compared HLA-DRB1 allele frequency in the reference and both test groups and revealed alleles that were associated with pathology (Table 4). Thus, there were statisti- cally significant differences in frequency for three $H L A-D R B 1 * 03(17), \quad H L A-D R B 1 * 12$, HLA-DRB $1 * 15$ alleles.

$H L A-D R B 1 * 12$ allele turned out to be positively associated with CMDAs $(O R=5.72$; CI 95\% 2.25-14.42; $p<0.0001)$. HLA-DRB1*15 allele turned out to be the same for children with CHDs $(O R=1.83$; CI 95\% 0.73-4.71; $p=0.03)$. Differences as per this allele were detected only against the reference group but not against the group with CMDAs. Negative association with CMDAs was detected for $H L A-D R B 1 * 03(17) \quad(O R=0.13 ; \quad C I \quad 95 \%$ $0.05-0.32 ; p=0.0008)$. Authentic differences as per its frequency were detected for the groups with CMDAs and CHDs.

Our research revealed that there was a deviation from basic population selection in the groups with CHDs and CMDAs. We revealed not only a deviation from calculated homozygosity for the CHDs group but also an authentic increase in frequency of common HLA$D R B 1 * 04$, female $H L A-D R B 1 * 07$ with male $H L A-D R B 1 * 13, H L A-D R B 1 * 17$ and female $H L A-D R B 1 * 13$ with male HLA-DRB $1 * 14$ in married couples. Besides, certain alleles were more frequent in married couples from the CHDs group against the reference one. Given 
Allele frequency in children from the examined groups

\begin{tabular}{|c|c|c|c|c|c|c|c|}
\hline \multirow{2}{*}{ Allele } & \multicolumn{2}{|c|}{ 1. Reference, children } & \multicolumn{2}{c|}{ 2. CMDAs, children } & \multicolumn{2}{c|}{ 3. CHDs, children } & \multirow{2}{*}{$p$} \\
\cline { 2 - 7 } & total $(n=264)$ & $\%$ & total $(n=136)$ & $\%$ & total $(n=96)$ & $\%$ & 0.05 \\
\hline 01 & 35 & 13.26 & 10 & 7.46 & 14 & 9.93 & \multirow{2}{*}{$p_{1.2}=0.0008 . p_{2.3}=0.004$} \\
\hline $03(17)$ & 37 & 14.02 & 2 & 1.49 & 15 & 10.64 & 0.05 \\
\hline 04 & 32 & 12.12 & 13 & 9.70 & 20 & 14.18 & 0.05 \\
\hline 07 & 25 & 9.47 & 10 & 7.46 & 20 & 14.18 & 0.05 \\
\hline 08 & 15 & 5.68 & 2 & 1.49 & 5 & 3.55 & 0.05 \\
\hline 09 & 10 & 3.79 & 1 & 0.75 & 1 & 0.71 & 0.05 \\
\hline 10 & 2 & 0.76 & 1 & 0.75 & 2 & 1.42 & 0.05 \\
\hline 11 & 34 & 12.88 & 24 & 17.91 & 24 & 17.02 & 0.05 \\
\hline 12 & 14 & 5.30 & 33 & 24.63 & 2 & 1.42 & $p_{1.2}<0.0001 . p_{2.3}=0.0001$ \\
\hline 13 & 24 & 9.09 & 15 & 11.19 & 10 & 7.09 & 0.05 \\
\hline 14 & 7 & 2.65 & 3 & 2.24 & 3 & 2.13 & $\mathrm{p}_{1.3}=0.03$ \\
\hline 15 & 24 & 9.09 & 19 & 14.18 & 22 & 15.60 & 0.05 \\
\hline 16 & 5 & 1.89 & 1 & 0.75 & 3 & 2.13 & \\
\hline
\end{tabular}

$\mathrm{N}$ o t e : $n$ is the total number of alleles in children, * means $p<0.05$.

that, we can state that married couples that in future would have children with sporadic CHDs without chromosome diseases were created under influence exerted by additional social or biological factors that resulted in their deviation from physiological biological assortativity as per HLA (deviation from random selection) and physiological social one (deviation from the reference group). This assumption is well in line with significant associations between sporadic CHDs in children and their parents' medical and social factors including their mutual feelings and caring about each other [17]. L.I. Korochkin notes that early ontogenesis in a wider sense begins long before actual fertilization and embryo-fetogenesis and such events as a married couple being created and gametogenesis can rightfully be called «pre-adaptive» processes that reflect stages in early ontogenesis [18]. At this stage in ontogenesis people do not make their choice on a future spouse randomly and this stage can become a key one in health or diseases of the next generation. It was proven that HLA locus played a certain role in determining assortative selection related to olfactory response to pheromone smells [19].

It is quite possible that occurrence of married couples with their children suffering from CHDs was assortative as per poor or good education, intellect, welfare, and other social factors [17]. Bearing in mind that HLA-DRB1 alleles are associated with immune-inflammatory diseases, we should pay attention to married couples in this group tending to have common $H L A-D R B 1 * 04$. Multiple research works have revealed that this allele is associated with such immune pathologies as rheumatoid arthritis, insulin-dependent pancreatic diabetes, psoriasis, and other diseases [13, 20, 21]. There is an opinion that presentation of antigens by HLA-DR molecule coded by this allele involves apparent T-helpers activation including partial auto-orientation. If we apply this statement on immune response to autoand allo-antigens within «mother-embryo / fetus» system, we can assume that inflammatory process is decompensated within this system and a heart disease develops in an embryo as inflammatory embryopathy. We also revealed more frequent (against the reference group) female $H L A-D R B 1 * 03(17)$ and male $H L A-D R B 1 * 04$ combination in this group of families. HLA-DRB1*03(17) allele is associated with such immune pathologies as systemic lupus erythematosus, insulin-dependent pancreatic diabetes, bronchial asthma, etc. [20, 21]. Given that, such families have high risks of inflammatory embryopathy including those resulting in congenital heart diseases.

Meiotic drive is the second stage in population selection; it is a non-random selection of 
gametes participating in fertilization that occurs due to asymmetric division during ovogenesis and spermatogenesis. Selection during fertilization is also admissible; it happens due to sperms being tropic to ovicells with certain HLA haplotype sets [7]. Immune interaction occurring between a semi-allogenic embryo and a mother's immune medium is a vital stage in selecting HLA inheritance from parents to their children [22]. It was proven that embryos bearing father's HLA antigens that were different from mother's antigens (histoincompatible pregnancy) had selective advantage in their survival against embryos with their father's HLA being identical to mother's ones (histo-compatible pregnancy) [12].

We should note that sensitivity or resistance to infectious and parasitic agents produces selective effects regarding HLA polymorphism. Thus, polymorphism occurrence in antigen-identifying sites of HLA molecules, classes I and II, is related to natural selection associated with infectious, parasitic, micro- and macro-environment [7]. Heterozygote preferences that are put into effect via over-dominant selection of HLA alleles resistant to infectious agents are of great importance. Frequency-dependent selection imposes certain limitations on growing population heterozygocity. Bearing in mind that immune identification of a pathogen is controlled with HLA, experts manages to obtain empiric evidence of frequency-dependent selection that was put into effect in such a way that specific HLA haplotypes were resistant to certain infectious agents and sensitive to other ones at the same time [7]. We should note that associated sensitivity and resistance to infectious agents begins at fetal age when a fetus comes into contacts with residential viruses and mother's microbiome.
All the above-mentioned allows us to interpret our results stating that there was homology as per $H L A D R B 1 * 12$ in families where children had CMDAs; as per female $H L A D R B 1 * 15$ and male HLADRB ${ }^{*} 07$, in families where children had CHDs. Thus, as per data take form literature [23] HLADRB1*12 is associated with sensitivity to herpetic viruses, and $H L A D R B 1 * 15$, opportunistic pathogens activation and occurrence of humoral adaptive immune responses to them as per IgG and $\mathrm{IgE}$ types (infectious-allergic process) [24]. Accordingly, a certain contribution is made into CMDAs occurrence by activation of residential virus genomes including those existing within «mother-embryo/fetus» system; CHDs occur due to, among other things, effects produced by opportunistic pathogens in female reproductive tracts.

Conclusion. HLADRB $1 * 12$ and $H L A D R B 1 * 15$ alleles are candidate not only regarding creation of a new scenario for population selection in case of CMDAs and CHDs accordingly, but also risk markers indicating congenital anomalies might occur taking into account deviations from proper biological assortativity as per HLA.

Funding. The present research was accomplished due to support provided for a complex fundamental research program approved by the RAS Siberian Branch within the fundamental subject No. 0546-2019-0002 accepted by the Scientific Research Institute for Complex Issues of Cardiovascular Diseases and entitled «Pathogenetic substantiation for developing implants for cardiovascular surgery made of biologically compatible materials and implementing a patient-oriented approach using mathematic modeling, tissue engineering, and genome predictors».

Conflict of interests. The authors declare there is no any conflict of interests.

\section{References}

1. Petersdorf E.W., O'hUigin C. The MHC in the era of next-generation sequencing: Implications for bridging structure with function. Human immunology, 2019, vol. 80, no. 1, pp. 67-78. DOI: 10.1016/j.humimm.2018.10.002

2. Chen N., Wang W., Wang F., Dong L., Zhao S., Zhang W., Zhu F. The distributions of HLA-A, HLA-B, HLA-C, HLA-DRB1 and HLA-DQB1 allele and haplotype at high-resolution level 
in Zhejiang Han population of China. International journal of immunogenetics, 2019, vol. 46, no. 1, pp. 7-16. DOI: 10.1111/iji.12411

3. Vojvodić S.I., Ademović-Sazdanić D.S. Distribution of HLA DRB1, DQA1 and DQB1 Allelic Main Groups in the Vojvodina Province of Serbia: Genetic Relatedness with Other Populations. Russian Journal of Genetics, 2019, vol. 55, no. 1, pp. 124-130. DOI: 10.1111/j.1744-313X.2012.01122.x

4. Zhang X., Cheng Y., Zhang Q., Wang X., Lin Y., Yang C., Fan X. [et al.]. Meta-Analysis Identifies Major Histocompatiblity Complex Loci in or Near HLA-DRB1, HLA-DQA1, HLA-C as Associated with Leprosy in Chinese Han Population. Meta-Analysis, 2019, vol. 139, no. 4, pp. 957-960. DOI: 10.1016/j.jid.2018.09.029

5. Kiseleva A.N., Butina E.V., Isaeva N.V., Zaitseva G.A., Pozdeev N.M., Ovchinnikov V.V. Distribution of antigens of the HLA-system in married couples with reproductive disorders. Obstetrics, Gynecology and Reproduction, 2019, vol. 13, no. 2, pp. 111-118. DOI: 10.17749/2313-7347.2019.13.2.111-118

6. Tashiro R., Niizuma K., Khor S.S., Tokunaga K., Fujimura M., Sakata H., Tominaga T. Identification of HLA-DRB1*04: 10 allele as risk allele for Japanese moyamoya disease and its association with autoimmune thyroid disease: A case-control study. PloS One, 2019, vol. 14, no. 8, pp. e0220858. DOI: 0.1371/journal.pone.0220858

7. Makarchenko O.S., Gordeeva L.A., Shabaldin A.V., Glushkova O.A., Shatalina I.V., Simonova T.A., Filipenko M.L., Glushkov A.N., Kryukov P.M. Genes' immune presentation and immunoregulations role in forming conditions for fetus's losses. Mat' i ditya $v$ Kuzbasse, 2008, vol. 34, no. 3, pp. 13-20 (in Russian).

8. Lopes S.A.V.D.A., Guimarães I.C.B., Costa S.F.D.O., Acosta A.X., Sandes K.A., Mendes C.M.C. Mortality for critical congenital heart diseases and associated risk factors in newborns. A cohort study. Arquivos brasileiros de cardiologia, 2018, vol. 111, no. 5, pp. 666-673. DOI: 10.5935/abc.20180203

9. Kafian A.S., Mirshahi A., Amouzeshi A., Ramazani A.A., Bahman B., Hasanzadeh T.M., Salehi F. Epidemiologic Study of Congenital Heart Diseases and Its Related Factors in Children Referred to the Pediatric Cardiac Clinic of Birjand University of Medical Sciences, Iran. International Journal of Pediatrics, 2019, vol. 7, no. 12, pp. 10455-10463. DOI: 10.22038/ijp.2019.41467.3497

10. Aimagambetova G., Hajjej A., Malalla Z.H., Finan R.R., Sarray S., Almawi W.Y. Maternal HLA-DR, HLA-DQ, and HLA-DP loci are linked with altered risk of recurrent pregnancy loss in Lebanese women: A case-control study. American Journal of Reproductive Immunology, 2019, vol. 82, no. 4, pp. e13173. DOI: 10.1111/aji.13173

11. Emmery J., Hachmon R., Pyo C.W., Nelson W.C., Geraghty D.E., Andersen A.M.N., Hviid T.V.F. Maternal and fetal human leukocyte antigen class Ia and II alleles in severe preeclampsia and eclampsia. Genes \& Immunity, 2016, vol. 17, no. 4, pp. 251-260. DOI: 10.1038/gene.2016.20

12. Grimstad F., Krieg S. Immunogenetic contributions to recurrent pregnancy loss. Journal of assisted reproduction and genetics, 2016, vol. 33, no. 7, pp. 833-847. DOI: 10.1007/s10815-016-0720-6

13. Guseva V., Lapin S., Myachikova V., Maslyanski A., Chuchlovin A., Ivanova N., Tkachenko O., Blinova T., Totolian A. Clinical importance of determination of hla-drb1 locus genes in rheumatoid arthritis. Medical Immunology (Russia), 2019, vol. 21, no. 2, pp. 333-340. DOI: 10.15789/15630625-2019-2-333-340

14. Bland J.M., Altman D.G. The odds ratio. BMJ, 2016, vol. 320, no. 7247, pp. 1468. DOI: 10.1136/bmj.320.7247.1468

15. Nunes M.E.G., Rosa D.V., Fagundes E.D.T., Ferreira A.R., Miranda D.M.D., Ferri Liu P.M. HLA-DRB1 gene polymorphisms in pediatric patients with type 1 autoimmune hepatitis and type 1 autoimmune hepatitis overlap syndrome with autoimmune cholangitis. Arquivos de gastroenterologia, 2019, vol. 56, no. 2, pp. 146-150. DOI: 10.1590/S0004-2803.201900000-29

16. Tashiro R., Niizuma K., Khor S.S., Tokunaga K., Fujimura M., Sakata H., Tominaga T. Identification of HLA-DRB $1 * 04: 10$ allele as risk allele for Japanese moyamoya disease and its association with autoimmune thyroid disease: A case-control study. PloS One, 2019, vol. 14, no. 8, pp. e0220858. DOI: 10.1371/journal.pone.0220858

17. Yu D., Feng Y., Yang L., Da M., Fan C., Wang S., Mo X. Maternal Socioeconomic Status and the Risk of Congenital Heart Defects in Offspring: A Meta-Analysis of 33 Studies. PLoS ONE, 2014, vol. 9, no. 10, pp. e111056. DOI: 10.1371/journal.pone.0111056 
18. Korochkin L.I. Ontogenez, evolyutsiya i geny [Ontogenesis, evolution, and genes]. Priroda, 2002, no. 7, pp. 63-77 (in Russian).

19. Chuyanova A.A., Tsepokina A.V., Shabaldin A.V., Litvinova N.A., Zubrikova K.Yu., Boldyreva M.N. Features olfactory screening for HLA-DRB1 among unrelated donors of different sex. Immunologiya, 2015, vol. 36, no. 2, pp. 90-95 (in Russian).

20. Kular L., Liu Y., Ruhrmann S., Zheleznyakova G., Marabita F., Gomez-Cabrero D., Aeinehband S. [et al.]. DNA methylation as a mediator of HLA-DRB1*15: 01 and a protective variant in multiple sclerosis. Nature communications, 2018, vol. 9, no. 1, pp. 1-15. DOI: 10.1038/s41467-018-04732-5

21. Eltayeb-Elsheikh N., Khalil E., Mubasher M., Al Jurayyan A., AlHarthi H., Omer W.H., Elghazali G. Association of HLA-DR-DQ alleles, haplotypes, and diplotypes with Type 1 diabetes in Saudis. Diabetes/Metabolism Research and Reviews, 2020, pp. e3345. DOI: 10.1002/dmrr.3345

22. Erlebacher A. Immunology of the maternal-fetal interface. Annu. Rev. Immunol, 2013, vol. 31, pp. 387-411. DOI: 10.1146/annurev-immunol-032712-100003

23. Kovalic A.J., Bonkovsky H.L. The Pathogenesis of Autoimmune Liver Diseases. In Diagnosis and Management of Autoimmune Hepatitis, 2020, pp. 9-50.

24. Eidan A.J., AL-Harmoosh R.A., Hadi Z.J. Association of HLA-DRB1 Alleles with Allergic Asthma and Total Serum IgE Levels in Iraqi Adults Patients. Indian Journal of Public Health Research \& Development, 2020, vol. 10, no. 1, pp. 505-510. DOI: 10.5958/0976-5506.2019.00099.8

Shabaldin A.V., Tsepokina A.V., Dolgikh O.V., Shabaldina E.V., Ponasenko A.V. Combination of hla-drb1 alleles as a factor causing risks of sporadic congenital heart defects and congenital malformations without chromosome diseases. Health Risk Analysis, 2021, no. 1, pp. 133-142. DOI: 10.21668/health.risk/2021.1.14.eng

Received: 26.09 .2020

Accepted: 03.03.2021

Published: 30.03 .2021 


\section{RISK ASSESSMENT IN PUBLIC HEALTHCARE}

UDC 614.451

DOI: $10.21668 /$ health.risk/2021.1.15.eng

Research article

\section{THEORETICAL GROUNDS FOR ASSESSING HEALTH RISKS FACTORS CAUSED BY SELF-ISOLATION}

\section{O.V. Mitrokhin, N.A. Ermakova, E.V. Belova}

I.M. Sechenov First Moscow State Medical University, 2 Bldg., 2 Bol'shaya Pirogovskaya Str., Moscow, 119435, Russian Federation

Billions of people had to face self-isolation for several months due to COVID-19 pandemic; given that, it seems quite vital to provide theoretical grounds for sanitary-hygienic health risk assessment.

Our research objects were people who had to self-isolate during CIVID-19 pandemic. In our research we provided theoretical substantiation for priority health risk factors determined by hypodynamia, hypoxia, improper nutrition, distorted work and leisure regime, and psychoemotional strain. These factors can result in growing morbidity with non-communicable diseases among population.

Our research goal was to give theoretical grounds for sanitary-hygienic assessment of health risk factors caused by self-isolation, to reveal priority health risk factors causing morbidity with non-communicable diseases, and to give recommendations on how to prevent it.

We applied analytical, information, and statistical procedures in our research. Data were obtained from regulatory and legal documents on sanitary-hygienic standardization in the Russian Federation, specifically, data on nutrition hygiene, occupational hygiene, children and teenagers hygiene, etc.; we also revised scientific works published by Russian and foreign authors and analyzed documents issued by the World Health Organization as well as by public healthcare authorities in different countries during COVID-19 pandemic.

When developing theoretical grounds for sanitary-hygienic assessment of health risk factors causing morbidity with non-communicable diseases due to self-isolation, we determined priority risk factors and suggested certain hygienic criteria for assessing self-isolation. We provided theoretical substantiation for a suggested hygienic self-isolation index and its score estimate. The existing system for sanitary-hygienic standardization in the RF fixes requirements for nutrition, work, and leisure regime as well as people's physical activity; it was applied for performing hygienic assessment of self-isolation and self-isolation index score estimates.

We suggested certain activities aimed at minimizing health risks under self-isolation; these activities were based on sanitary-hygienic standards. Since hypodynamia and hypoxia are primary sanitary-hygienic health risk factors, we suggest sticking to adequate nutrition with optimal energy capacity, proper physical activity, as well as proper work and leisure regimes.

Key words: COVID-19, self-isolation, health risk assessment, sanitary-hygienic standardization, prevention, hygiene, risk factors, population health.

Self-isolation is a set of enforced administrative, sanitary-hygienic, sanitary-epidemiological, and preventive activities aimed at preventing infectious agents from transfer to susceptible and contact people; the basic aim here is to prevent risks of coronavirus infec- tion spread and new contagions among population [1].

From hygienic point of view, selfisolation should be defined as forced long-term (longer than one month) amount of time spent by a person within limited space, with lower

(C) Mitrokhin O.V., Ermakova N.A., Belova E.V., 2021

Oleg V. Mitrokhin - Doctor of Medical Sciences, Professor, Head of the Common Hygiene Department (e-mail: mov1163@yandex.ru; tel.: +7 (499) 248-19-65; ORCID: https://orcid.org/0000-0002-6403-0423).

Nina A. Ermakova - Senior lecturer at the Common Hygiene Department (e-mail: ninaok11@gmail.com; tel.: +7 (916) 150-07-06; ORCID: https://orcid.org/0000-0002-9745-4265).

Elena V. Belova - Assistant lecturer at the Common Hygiene Department (e-mail: ms.ekochina@mail.ru; tel.: +7 (985) 085-39-95; ORCID: https://orcid.org/0000-0002-2134-6348). 
physical activity, and insufficient amount of time spent outdoors [2].

There are several types of self-isolation: a scientific experiment; healthy people and patients with mild forms of a disease isolating themselves at home; medical personnel isolating themselves at their workplaces [3].

Self-isolation first became a part of a scientific experiment when research was being accomplished on space flights in late 60-ties last century by the RAS Institute for Medical and Biological Issues ${ }^{1}$. There was profound diagnostic research on nutritional status, food habits or changes in them that occurred due to the same diet being consumed for a long period of time in isolated conditions [4]. The tests also revealed that isolated people started to suffer from crucial mental issues [5].

In 2020 SIRIUS-19, an international isolation experiment, started with its program covering a 5-year period. The research focuses on examining space crew activity in an artificial environment; it will allow developing optimal medical and sanitary standards, determining relevant food resources and prevention activities. As a result, a series of examinations will enable creating medical and sanitary requirements to layouts of personal space inside future space bases and ships. The experiment results will also provide an opportunity to predict risk factors producing negative effects under isolation and how to prevent them as well as to develop various procedures for improving crew members' health. This self-isolation is voluntary as people give their consent to take part in scientific experiments and they are provided with constant medical surveillance and support ${ }^{2}$.

People who had mild forms of the disease, those who had contacts with infected people, elderly people who were older than 65 , and even healthy people had to keep self-isolation at home for a long period of time in order to prevent the infectious agent spread in population. Certain measures were introduced to make people keep «social distance» and use antiseptics and personal protective equipment (face masks and gloves) in public places; mass media provided people with relevant data on how to prevent the coronavirus infection spread among population [6].

Long periods of time spent indoors, minimized social interaction, nutrition and physical activity being in disharmony lead to greater health risks for population due to occurring and exacerbating somatic and mental diseases [7].

Self-isolation concerns a great share of population including people of different sex and age and those who already suffer from various chronic diseases. Self-isolation is aggravated with great nervous tension and its long periods, up to several months [8].

Our research goal was to give theoretical grounds for sanitary-hygienic assessment of health risk factors caused by self-isolation, to reveal priority health risk factors causing morbidity with non-communicable diseases, and to give recommendations on how to prevent it.

\section{The research tasks were as follows:}

1. To reveal health risk factors for people who isolated themselves;

2. To provide theoretical grounds for complex hygienic assessment of self-isolation as per priority criteria;

3. To provide theoretical grounds for developing hygienic self-isolation index and a score estimate for assessing health risks for population;

4. Torecommend activities aimed at minimizing health risks for people who were self-isolated.

Data and methods. We applied statistical, information, and analytical procedures in our research, analyzed databases containing regulatory and legal documents on sanitary-hygienic standardization issued in the Russian Federation.

We took data from hygienic standards and physiological regulations on the following subjects: nutrition hygiene (determining physical activity coefficient during self-isolation,

\footnotetext{
${ }^{1}$ «Mars 500» project. Mars 500. Available at: http://mars500.imbp.ru/history.html (05.06.2020) (in Russian).

${ }^{2}$ «Mars 500» experiment has come to its end. Roscosmos. Available at: https://www.roscosmos.ru/17692/ (05.06.2020) (in Russian).
} 
standards fixing proper caloric content in food for different age and sex groups, etc.); children and teenagers hygiene (working space layout, nutrition, a child's physical activity); occupational hygiene; etc.

We also analyzed documents and methodical recommendations issued by the WHO that focused on preventing psychoemotional disorders and alimentary-dependent diseases among population as well as experience gained by public healthcare systems in other countries during the coronavirus infection pandemic.

Results and discussion. Self-isolation led to new risk factors occurring and it called for accomplishing sanitary-hygienic assessment and developing activities aimed at preventing negative effects produced by them on people's health [9]. These risk factors include the following:

- hypodynamia (low physical activity) due to a person spending long periods of time indoors in a limited space [10];

- hypoxia (poor blood saturation with oxygen) due to limited amount of time spent in the open air [11];

- alimentary factors (probable improper nutrition when people consume food with high caloric contents but their physical activity is too low for that) [12];

- changes in work and leisure regimes [13].

In the Russian Federation a database of sanitary-hygienic standards was created that included hygienic standards and recommended physiological norms concerning food, physical activity, and work and leisure regime [14].

Sanitary-hygienic standards are applied to assess proper nutrition according to energy inputs by different sex and age groups. Hygienic standards are applied to fix physiologically op- timal amount of time spent indoors ${ }^{3}$, to determine proper parameters of microclimate, physical activity, and work and leisure regime ${ }^{4}$.

It seems advisable and necessary to apply hygienic standards to assess self-isolation.

In Russia there are standards for physiological need in energy and nutrients for different population groups; these standards determine physiologically grounded consumption rates for essential nutrients and energy sources.

Need in energy and nutrients depends on physical activity that is characterized with physical activity coefficient. This coefficient is determined as a ratio of energy inputs necessary to accomplish a specific task and basic metabolism value. Overall adult population is divided into 5 groups for men and 4 groups for women depending on energy inputs; this division is accomplished taking into account physical activity at workplaces and other energy inputs. It seems advisable to apply group I for selfisolation since it is characterized with such a risk factor as low physical activity both for men and women. This group predominantly includes people with intellectual labor (researchers, HEE lecturers, students, medical personnel, etc.). Physical activity coefficient is equal to 1.4 for these occupational groups 5 .

Students who attend secondary schools as well as educational establishments for primary and secondary vocational training and who have to switch to distance learning should adhere to recommended nutrition standards. SER 2.4.5.2409-08 provide a draft menu that was developed taking into account need in basic nutrients and sticking to recommended caloric contents in day ration; the menu is differentiated as per age groups $(8-11 ; 12-18)^{6}$.

${ }^{3}$ SER 2.1.2.2645-10. Sanitary-epidemiologic requirements to living conditions: Sanitary-epidemiologic rules and standards. KODEKS: an electronic fund for legal and reference documentation. Available at: http://docs.cntd.ru/document/902222351 (05.06.2020) (in Russian).

${ }^{4}$ SER 2.2.4.3359-16. Sanitary-epidemiologic requirements to physical factors at workplaces: Sanitary-epidemiologic rules and standards. KODEKS: an electronic fund for legal and reference documentation. Available at: http://docs.cntd.ru/document/420362948 (05.06.2020) (in Russian).

${ }^{5}$ MR 2.3.1.2432-08. 2.3.1 issued on December 18, 2008. Rational nutrition. Standards for physiological needs in energy and nutrients for different population groups in the Russian Federation: Methodical guidelines. Moscow, The Federal Service for Surveillance over Consumer Rights Protection and Human Well-being Publ., 2008, pp. 6-8 (in Russian).

${ }^{6}$ SER 2.4.5.2409-08. Sanitary-epidemiologic requirements to organizing meals for students attending secondary schools and educational establishments for primary and secondary vocational training: Sanitary-epidemiologic rules and standards. KODEKS: an electronic fund for legal and reference documentation. Available at: http://docs.cntd.ru/document/902113767 (05.06.2020) (in Russian). 
When children have to learn at home, special attention should be paid to pauses between doing learning tasks and studying teaching materials. A room where a child studies should be ventilated regularly and he or she should spend this time in the open air (on a balcony or in a yard) so that fatigue is prevented. Biological needs in physical activity should also be satisfied so parents have to make children do some exercises or do sports on training devices etc. ${ }^{7}$.

We suggest the following sanitary-hygienic criteria for assessing self-isolation as a risk factor causing non-communicable diseases occurrence among population:

- a place where people isolate themselves (an apartment, a country house, a hotel, etc.) since it determine whether they can spend some time outdoors to prevent hypoxia [15];

- a total square per one self-isolated person since it determines, among other things, available physical activity [16];

- physical activity including physical loads, doing sports on training devices, exercises etc. [17];

- amount of time spent outdoors including walking pets, shopping, going to a chemist's, frequent ventilating, spending some time on balconies etc. [18];

- work regime for those who work at home using IT;

- leisure regime [19];

- psychoemotional tension, long time spent indoors, stress [20].

These established sanitary-hygienic criteria for self-isolation assessment provide theoretical grounds for hygienic self-isolation index. This index allows determining risks of non-communicable morbidity during self-isolation basing on established hygienic standards and recommended physiological ones.

Hygienic self-isolation index (HSI) is directly proportionate to coefficients of physical activity (D), square (air volume) per one isolated person (S), amount of time spent outdoors $(\mathrm{T})$; it is inversely proportionate to caloric contents in consumed food (K).

$$
H S I=\frac{D+S+T}{K}
$$

where:

$\mathrm{D}$ is a coefficient of physical activity that is calculated as per the following formula: actual physical activity (number of kilocalories spent on physical exercises) / time spent on doing physical exercises. Recommendations on physical activity that is necessary to preserve and improve health are given for all age groups on the World Health Organization web-site ${ }^{8}$.

$\mathrm{S}$ is a coefficient showing actual square (air volume) indoors; it is $3 \mathrm{~m}^{3} /$ hour per $1 \mathrm{~m}^{2}$ of a living space in case overall living space is less than $20 \mathrm{~m}^{2}$ per one person and not less than $30 \mathrm{~m}^{3} /$ hour per one person in case overall living space per this one person is more than $20 \mathrm{~m}^{2}$.

$\mathrm{T}$ is amount of time spent outdoors (hours).

$\mathrm{K}$ is a coefficient that shows a ratio between actual caloric contents in food (these contents are given on any food product label) and physiological standard for caloric contents in food (adult males require from 2,100 to 4,200 kilocalories a day and adult females, from 1,800 to 3,050 kilocalories a day) ${ }^{10}$.

\footnotetext{
${ }^{7}$ Global recommendations on physical activity necessary for health. Available at: https://www.who.int/dietphysicalactivity/factsheet_recommendations/ru/ (05.06.2020) (in Russian).

${ }^{8}$ Code of instructions: apartments blocks: CI 54.13330.2016 Housing apartments blocks. KODEKS: an electronic fund for legal and reference documentation. Available at: http://docs.cntd.ru/document/456054198 (05.06.2020) (in Russian).

${ }^{9}$ SER 2.3.2.1078-01. Hygienic requirements to safety and nutritional value of food products: Sanitary-epidemiologic rules and standards. KODEKS: an electronic fund for legal and reference documentation. Available at: http://docs.cntd.ru/ document/901806306 (05.06.2020) (in Russian).

${ }^{10}$ Principles for drawing up a ration for self-isolated people or people on quarantine at home. Ofitsial'nyi sait Upravleniya Federal'noi sluzhby po nadzoru v sfere zashchity prav potrebitelei i blagopoluchiya cheloveka po gorodu Moskve. Available at: http://77.rospotrebnadzor.ru/index.php/napravlenie/profinfzab/8142-fits-pitaniya-i-biotekhnologii-razrabotal-printsipy-ratsionadlya-lits-nakhodyashchikhsya-v-rezhime-samoizolyatsii (05.06.2020) (in Russian).
} 
Bearing this hygienic self-isolation index in mind, we can conclude that more physical activity a person has outdoors or in a ventilated room and consumes calories in quantities relevant to his or her energy inputs, the lower are health risks caused by such factors as hypodynamia, hypoxia, or obesity [21].

It seems possible to provide score estimate for hygienic assessment of self-isolation. Hygienic self-isolation index which is equal to 3 is optimal; more than 3, favorable; lower than 3; unfavorable.

Accomplished sanitary-hygienic assessment of self-isolation will allow preventing alimentary-dependent diseases, cardiovascular diseases, and diseases of the musculoskeletal system as well as reducing risks of other non-communicable diseases [22].

Self-isolation and keeping social distance during a pandemic (epidemic) are factors that allow reducing risks of people getting infected with infectious agents.

During self-isolation it is important to follow recommendations on survival rations in case of a pandemic or any other emergency (catastrophe) [23].

Infectious epidemics not only influence people's physical health but also exert adverse impacts on mental health and well-being of non-infected people. Research revealed that spread of new communicable diseases and their consequences such as severe acute respiratory syndrome (SARS) could result in greater anxiety, depression, and stress among population in general [24]. These negative emotions influence sleep as well [25].

During COVID-19 epidemic in China some people who had mild diseases, suspected contagion, or close contacts with infected patients or potentially hazardous environment were isolated at their homes. Even if isolated people didn't fall sick with the disease and remained physically healthy, they often suffered from negative mental outcomes [26]. Therefore, it is vital to preserve mental and physical health of people who isolated themselves due to elevated risks of COVID-19 contagion [27].

\section{Conclusions:}

- we determined leading health risk factors during self-isolation;

- we provided theoretical grounds for sanitary-hygienic criteria that could be applied to assess self-isolation basing on sanitary-hygienic standards existing in the Russian Federation;

- we substantiated and developed hygienic self-isolation index (HIS) that is directly proportionate to coefficients of physical activity (D), square (air volume) per one isolated person $(S)$, amount of time spent outdoors $(T)$ and is inversely proportionate to caloric contents in consumed food $(K)$;

- we suggested a score estimate for hygienic self-isolation index that provides optimal, favorable, and unfavorable risk assessment for impacts exerted by self-isolation on people's health;

- accomplished sanitary-hygienic assessment of self-isolation will allow preventing communicable morbidity among population and test theoretically well-grounded assessment of health risks caused by self-isolation in field observations.

Recommendations. Nutrition. During self-isolation food ration should be given special attention. Food products with high sugar or salt contents, confectionary, and fast food are risk factors that can cause alimentarydependent diseases [28]. It is necessary to drink not less than 2 liters of water per day and abstain from having sugary and floury products, sweet fizzy drinks, fat meat and cheese, fast food, chips, etc. ${ }^{11}$.

Physical activity. During forced selfisolation it is vital to keep relevant physical activity that exerts favorable impacts both on physical and mental health [29]. Physical exercises are recommended to be followed with muscle relaxation $^{12}$.

\footnotetext{
${ }^{11}$ How to keep physically fit during self-isolation. Available at: http://cgon.rospotrebnadzor.ru/upload/medialibrary/34a/34a623bbfeb0a9bd5b0d4fbd23aa5a3d.png (05.06.2020) (in Russian).

${ }^{12}$ Distant learning for schoolchildren. Available at: http://cgon.rospotrebnadzor.ru/upload/medialibrary/8ee/ 8eec6ead367b43c78a1d3332691200ce.png (05.06.2020) (in Russian).
} 
Work and leisure regime. Self-isolation involves remote working for adults and distant learning for children and comfortable conditions are required for that [30]. Rooms where people work or study should be ventilated and cleaned daily and there should be no irrelevant noise sources ${ }^{13}$. People should sleep for not less than 8 hours a day, eat rationally and properly, and remain physically active [31].

Funding. The research was not granted any sponsor support.

Conflict of interests. The author declares there is no any conflict of interests.

\section{References}

1. Singh J.A COVID-19: Mandatory institutional isolation v. Voluntary home self-isolation. South African Medical Journal, 2020, vol. 110, no. 6, pp. 453-455. DOI: 10.7196/SAMJ.2020v110i6.14840

2. Baker E.A., Clark L.L.B. Biopsychopharmacosocial approach to assess impact of social distancing and isolation on mental health in older adults. British journal of community nursing, 2020, vol. 25, no. 5, pp. 231-238. DOI: 10.12968/bjcn.2020.25.5.231

3. Meinert E.A., Milne-Ives M.A., Surodina S.C., Lam C.A.D. Agile requirements engineering and software planning for a digital health platform to engage the effects of isolation caused by social distancing: Case study. Journal of Medical Internet Research, 2020, vol. 22, no. 5, pp. 1-10. DOI: $10.2196 / 19297$

4. Agureev A.N., Afonin B.V., Sedova E.A., Solovieva A.A., Valuev V.A., Sidorenko L.A. Nutritional Status in the Experiment with 105-Day Isolation as the First Phase of the Mars-500 Project. Hum. Physiol, 2017, no. 43, pp. 793-801.

5. Rosa C.B., Bañosbc M., Etchemendyb E., García-Palaciosab A., Alcañizbd M. Psychological countermeasures in manned space missions: «EARTH» system for the Mars-500 project. Computers in Human Behavior, 2016, vol. 55, part B, pp. 898-908. DOI: 10.1016/j.chb.2015.10.010

6. Zhang X., Wang F., Zhu C., Wang Z. Willingness to self-isolate when facing a pandemic risk: Model, empirical test, and policy recommendations. International Journal of Environmental Research and Public Health, 2020, vol. 17, no. 1, pp. 1-15. DOI: 10.3390/ijerph17010197

7. Bacon A.M., Corr P.J. Coronavirus (COVID-19) in the United Kingdom: A personality-based perspective on concerns and intention to self-isolate. British Journal of Health Psychology, 2020, pp. 1-10. DOI: $10.1111 /$ bjhp. 12423

8. Vjekoslav P., Zatezalo V.G., Karlović D. Mental health issues and psychological crisis interventions during the COVID-19 pandemic and earthquakes in Croatia. Review paper, 2020, vol. 56, no. 2, pp. 193-198. DOI: 10.20471/dec.2020.56.02.07

9. Zaitseva N.V., Shur P.Z., Kiryanov D.A., Chigvintsev V.M., Dolgikh O.V., Luzhetskii K.P. Methodical approaches to calculating the probability of negative responses for personal human health risk assessment. Profilakticheskaya i klinicheskaya meditsina, 2015, vol. 56, no. 3, pp. 5-11 (in Russian).

10. Maio G.D.A., Monda V.A., Messina A.A., Polito R.B., Tartaglia N.C., Ambrosio A.C., Pisanelli D.B., Asmundo A.E. [et al.]. Physical activity and modification of lifestyle induce benefits on the health status. Acta Medica Mediterranea, 2020, vol. 36, no. 3, pp. 1913-1919. DOI: $10.1155 / 2017 / 3831972$

11. Bogdan I.V., Gurylina M.V., Chistyakova D.P. The healthy life-style: attitude of population and priority directions. Problemy sotsial'noi gigieny, zdravookhraneniya i istorii meditsiny, 2019, vol. 27, no. 4, pp. 374-378 (in Russian).

12. Lister N., Jebeile H., Truby H., Garnett S.P., Varady K.A., Cowell C.T., Collins C.E., Paxton S.J. [et al.]. Fast track to health - Intermittent energy restriction in adolescents with obesity. A randomised controlled trial study protocol. Obesity Research and Clinical Practice, 2020, vol. 14, no. 1, pp. 80-90. DOI: 10.1016/j.orcp.2019.11.005

\footnotetext{
${ }^{13}$ How to cope with stress. Available at: http://cgon.rospotrebnadzor.ru/upload/medialibrary/09a/09a20a55807 cf40671f0d7151c609aed.png (05.06.2020) (in Russian).
} 
13. Galli F., Reglero G., Bartolini D., Visioli F. Better prepare for the next one. Lifestyle lessons from the COVID-19 pandemic. Pharma Nutrition, 2020, vol. 12, pp. 100193. DOI: 10.1016/j.phanu.2020.100193

14. Onishchenko G.G. Actual problems of hygiene science and practice in the preservation of public health. Gigiena i sanitariya, 2015, vol. 94, no. 3, pp. 5-9 (in Russian).

15. Madzhuga A.G., Shashina E.A., Romanov D.B., Khersonskii I.I. Peculiarities of axiological adaptation of university students: health-creating approach. Teoriya i praktika fizicheskoi kul'tury, 2020, no. 5, pp. 37-38 (in Russian).

16. Hoffmann J., Günther J., Geyer K., Stecher L., Rauh K., Kunath J., Meyer D., Sitzberger C. [et al.]. Effects of a lifestyle intervention in routine care on prenatal physical activity - Findings from the cluster-randomised. BMC Pregnancy and Childbirth, 2019, vol. 19, no. 1, pp. 1-13. DOI: 10.1186/s12884-019-2553-7

17. Zaninotto P., Head J., Steptoe A. Behavioural risk factors and healthy life expectancy: evidence from two longitudinal studies of ageing in England and the US. Scientific Reports, 2020, vol. 10, no. 1, pp. 1-9 (in Russian).

18. Hart D.A., Zernicke R.F. Optimal human functioning requires exercise across the lifespan: mobility in a $1 \mathrm{~g}$ environment is intrinsic to the Integrity of multiple biological systems. Frontiers in Physiology, 2020, vol. 11, pp. 1-11. DOI: 10.3389/fphys.2020.00156

19. Kramer A., Kramer K.Z. The potential impact of the COVID-19 pandemic on occupational status, work from home, and occupational mobility. Journal of Vocational Behavior, 2020, vol. 119, pp. 1-4. DOI: $10.1016 /$ j.jvb.2020.103442

20. Carbone S.R. Flattening the curve of mental ill-health: the importance of primary prevention in managing the mental health impacts of COVID-19. Mental Health and Prevention, 2020, vol. 19, pp. 200185. DOI: $10.1016 /$ j.mhp.2020.200185

21. Krut'ko V.N., Dontsov V.I., Potemkina N.S., Smirnova T.M., Fedin K.A., Fedina A.V., Bol'shakov A.M., Khodykina T.M. Information and cognitive technologies of health saving (review). Trudy Institute sistemnogo analiza Rossiiskoi akademii nauk, 2019, vol. 69, no. 1, pp. 50-60 (in Russian).

22. Zhai Y., Du X. Addressing collegiate mental health amid COVID-19 pandemic. Psychiatry Research, 2020, vol. 288, pp. 113003. DOI: 10.1016/j.psychres.2020.113003

23. Chatterjee A., Gerdes M.W., Martinez S.G. Identification of risk factors associated with obesity and overweight - a machine learning overview. Sensors, 2020, vol. 20, no. 9, pp. 1-30. DOI: $10.3390 / \mathrm{s} 20092734$

24. Gómez-Salgado J., Andrés-Villas M., Domínguez-Salas S., Díaz-Milanés D., Ruiz-Frutos C. Related health factors of psychological distress during the COVID-19 pandemic in Spain. International Journal of Environmental Research and Public Health, 2020, vol. 17, no. 11, pp. 3947. DOI: 10.3390/ijerph17113947

25. Shen L., Schie J., Ditchburn G., Bei B. Positive and negative emotions: Differential associations with sleep duration and quality in adolescents. J. Youth Adolescence, 2018, vol. 47, no. 12, pp. 2584-2595. DOI: 10.1007/s10964-018-0899-1

26. Júnior J.G., Moreira M.M., Pinheiro W.R., De Amorim L.M., Lima C.K., Da Silva C. G. L., Neto M.L.R. The mental health of those whose rights have been taken away: An essay on the mental health of indigenous peoples in the face of the 2019 Coronavirus (2019-nCoV) outbreak. Psychiatry Research, 2020, vol. 289, pp. 113094. DOI: 10.1016/j.psychres.2020.113094

27. Tzur Bitan D., Grossman-Giron A., Bloch Y., Mayer Y., Shiffman N., Mendlovic S. Fear of COVID-19 scale: Psychometric characteristics, reliability and validity in the Israeli population. Psychiatry Research, 2020, vol. 289, pp. 113100. DOI: 10.1016/j.psychres.2020.113100

28. Bullón-Vela V., Abete I., Ángeles Zulet M., Tur J.A., Pintó X., Corbella E., MartínezGonzález M.A., Corella D. [et al.]. Risk factors differentially associated with non-alcoholic fatty liver disease in males and females with metabolic syndrome. Revista Espanola de Enfermedades Digestivas, 2020, vol. 112, no. 2, pp. 94-100. DOI: 10.17235/reed.2019.6031/2018

29. Heinicke V., Halle M. Lifestyle intervention in the primary prevention of cardiovascular diseases. Herz, 2020, vol. 45, no. 1, pp. 30-38. DOI: 10.1007/s00059-019-04886-y 
30. Savić D. COVID-19 and work from home: Digital transformation of the workforce. Grey Journal, 2020, vol. 16, no. 2, pp. 101-104 (in Russian).

31. Rimmer A. How can i keep calm during self-isolation? The BMJ, 2020, vol. 369, pp. m1376. DOI: $10.1136 / \mathrm{bmj} . \mathrm{m} 1376$

Mitrokhin O.V., Ermakova N.A., Belova E.V. Theoretical grounds for assessing health risks factors caused by self-isolation. Health Risk Analysis, 2021, no. 1, pp. 143-150. DOI: 10.21668/health.risk/2021.1.15.eng

Received: 19.09 .2020

Accepted: 07.02.2021

Published: 30.03 .2021 
UDC 614.446.1: 578.834 .1

DOI: 10.21668/health.risk/2021.1.16.eng

Research article

\title{
APPROACHES TO ANALYZING EFFICIENCY OF RESPIRATORY PROTECTIVE EQUIPMENT AS A WAY TO REDUCE HEALTH RISKS DURING COVID-19 PANDEMIC
}

\author{
E.A. Shashina ${ }^{1}$, T.S. Isiutina-Fedotkova ${ }^{1}$, V.V. Makarova ${ }^{1}$, O.A. Gruzdeva ${ }^{1,2}$, O.V. Mitrokhin ${ }^{1}$ \\ ${ }^{1}$ I.M. Sechenov First Moscow State Medical University, Bldg. 2, 8 Trubetskaya Str., Moscow, 119991, Russian Federation \\ ${ }^{2}$ Center for Hygiene and Epidemiology in Moscow, the Central Administrative District brunch, Bldg. 1, 17 \\ Krasnogvardeiskii blvd., Moscow, 123317, Russian Federation
}

\begin{abstract}
Use of respiratory protective equipment (RPE) has become the most significant way to prevent the coronavirus infection from its rapid spread.

Our research goal was to analyze efficiency of various RPE used by people during COVID-19 pandemic.

We made a review focusing on RPE manufactured and tested as per standards existing in different counties; we also analyzed the State Medical Equipment Register of the Federal Service for Surveillance in Public Healthcare as well as a market where respiratory protective equipment available to people was distributed.

$R P E$ is quite variable as per such parameters as bacterial filtration efficiency, number of layers and quality of a material it is made of, being fit to a person's face (masks for children/adults), conditions for use (a time of use, whether a mask can be disinfected and used again, etc.). Data provided for customers when respiratory protective equipment is sold are rather scarce and controver sial (people do not understand what a mask name means and how efficiently it protects their respiratory organs). Respiratory protective equipment which is registered within the State Medical Equipment Register of the Federal Service for Surveillance in Public Healthcare accounts for only $24 \%$ of the overall equipment sold to consumers. Taking into account variable and multiple properties of different masks, we developed a RPE classification basing on their efficiency when it comes down to protection from respiratory infections. FFP3/KN100/N99/N100 respirators are the most efficient ones. FFP2/KN95/N95/DS/DL2/KF94 respirators have average efficiency. FFP1 respirators and nonwoven medicals masks, II R, II, I type, and woven gauze masks have efficiency that is lower than average (RPE is mentioned in a descending order as per its efficiency). Low and extremely low efficiency was established accordingly for various non-medical masks (nonwoven, woven cotton, and synthetic ones) and face shields.

When RPE is manufactured and sold, there are no precise criteria for assessing its protective efficiency. There is either no unified approach to such concepts as «medical» and «non-medical» masks. Most respiratory protective equipment sold on the consumer market in Russia is not registered within the Russian State Medical Equipment Register of the Federal Service for Surveillance in Public Healthcare. Our classification allows working out a unified approach to providing data on respiratory protective equipment for consumers.

Key words: pandemic, COVID-19, respiratory protective equipment, medical mask, non-medical mask, bacterial filtration efficiency, the State Medical Equipment Register, protective equipment market.
\end{abstract}

Coronavirus infection pandemic that started in December 2019 in Wuhan, China's Hubei province, spread all over the world in 2020 and is now a global threat to the whole mankind [1]. According to WHO data, by February 10, 2021 106,555,206 confirmed COVID19 cases were registered all over the world, including 2,333,446 deaths; in Russia, 4,012,710 cases and 78,134 deaths accordingly [2].
Efforts made by numerous scientists have yielded much desirable results as vaccines against COVID-19 have been created and allowed starting mass immunization among population. However, WHO experts predict that collective immunity to the virus will start to form only by the end of 2021 [3].

Since respiratory way and a direct contact are basic ways for COVID-19 contagion, non-

(c) Shashina E.A., Isiutina-Fedotkova T.S., Makarova V.V., Gruzdeva O.A., Mitrokhin O.V., 2021

Ekaterina A. Shashina - Candidate of Medical Sciences, Associate Professor at the Common Hygiene Department (e-mail: shashina_e_a@staff.sechenov.ru; tel.: +7 (499) 248-51-55; ORCID: http://orcid.org/0000-0002-5294-6813).

Tatiana S. Isiutina-Fedotkova - Candidate of Medical Sciences, Associate Professor at the Common Hygiene Department (e-mail: isyutina-fedotkova_t_s@staff.sechenov.ru; tel.: +7 (499) 248-51-55; ORCID: https://orcid.org/0000-0001-8423-9243).

Valentina V. Makarova - Candidate of Medical Sciences, Associate Professor at the Common Hygiene Department (e-mail: makarova_v_v@staff.sechenov.ru; tel.: +7 (499) 248-51-55; ORCID: http://orcid.org/0000-0002-7213-4265).

Olga A. Gruzdeva - Doctor of Medical Sciences, Chief Physician (e-mail: fguzmoscao@mail.ru; tel.: +7 (499) 256-71-15; ORCID: http://orcid.org/0000-0002-1244-1925).

Oleg V. Mitrokhin - Doctor of Medical Sciences, Professor, Head of the Common Hygiene Department (e-mail: mitrokhin_o_v@staff.sechenov.ru; tel.: +7 (499) 248-53-85; ORCID: http://orcid.org/0000-0002-6403-0423). 
specific preventive activities become especially significant; such activities include social distancing, control over possible contacts with infected people, quarantine, isolation, and hand hygiene [4-7]. Use of respiratory protective equipment turned out to be among the most efficient protective actions against respiratory contagion with the virus $[8,9]$.

Basing on multiple studies, the World Health Organization issued recommendations on how to use face masks as the primary measure in fighting against COVID-19 spread. And in 2021 the WHO experts consider wearing face masks to be the most important activity that helps restraining and eliminating the pandemic; they note that it is necessary to wear a face mask indoors and outdoors in case it is impossible to keep a safe distance between people equal to 1 meter [10].

Basically, masks allow maintaining control over infection sources since they prevent the virus from spreading from one person to another thus reducing a risk that people might infect each other. Multiple research works, including those that involve mathematic modeling, show that even a slight decrease in individual transfer of the virus can result in a significant decrease in its spread among population [11-14].

Face masks wearing is among preventive activities that can be implemented rapidly and efficiently and require minimal costs. They should be easily available to the whole population and this availability is a key factor that influences provision of population with face masks.

Obligatory face masks wearing was introduced and is still valid in most Russian Federation (RF) regions according to the orders issued by the RF Chief Sanitary Inspector as well as by local authorities; face masks should be worn in public places, public transport, elevators, all objects where services to population are rendered, in public healthcare organizations, and educational establishments ${ }^{1,2}$.
Besides, risks that biological threats might occur will persist in future (known microorganisms mutating and new ones occurring); therefore, an issue related to providing population with qualitative respiratory protective equipment will remain vital.

Our research goal was to analyze efficiency of respiratory protective equipment that people use during COVID-19 pandemic. To achieve this goal, we solved the following tasks:

- we accomplished a review of respiratory protective equipment (RPE) that is used as nonspecific prevention measure during the pandemic;

- analyzed the State Medical Equipment and Organizations (Private entrepreneurs) Register of the Federal Service for Surveillance in Public Healthcare;

- analyzed the market where respiratory protective equipment available to people was distributed;

- developed RPE classification.

Data and methods. Respiratory protective equipment was examined and assessed as per Russian, interstate, European, Chinese, and American standards; sanitary rules and orders issued by the RF State Sanitary Service; methodical guidelines issued by the RF Public Healthcare Ministry, World Health Organization, and US Centers for Disease Control and Prevention regarding the coronavirus infection prevention and use of respiratory protective equipment during the pandemic.

Market offers made by different manufactures of respiratory protective equipment were analyzed using «Yandex Market», a service helping customers to select products or goods they needed.

Results and discussion. A review of respiratory protective equipment used as a nonspecific prevention measure during the pandemic. People use a great variety of respiratory protective equipment during this pandemic.

Filtrating face half masks are respiratory protective equipment aimed at achieving very

\footnotetext{
${ }^{1}$ SR 3.1.3597-20. Prevention of the new coronavirus infection (COVID-19). KonsultantPlus. Available at: http://www.consultant.ru/document/cons_doc_LAW_353494/e4deaf074c290821400cfad27f87d23d667c4cfd/ (03.02.2021) (in Russian).

${ }^{2}$ On additional activities aimed at reducing risks of COVID-19 spread during a seasonal rise in morbidity with acute respiratory virus infections and flu: The Order by the RF Chief Sanitary Inspector issued on October 16, 2020. Garant: information and legal database. Available at: http://base.garant.ru/74811008/ (03.02.2021) (in Russian).
} 
tight fitting with a face and protecting the respiratory organs both from solid and liquid aerosols. Respirators with a filtrating mask (FFP (the European Union), N (the USA), KN (China), DS/DL (Japan), and KF (South Korea)) are made of several layers (not fewer than 6), and these layers, as a rule, are nonwoven polypropylene ones. A layer that is made via being blown out from melted material is the most significant one since fiber in such non-woven material can be arranged in a pile thus creating a three-dimensional net with $90 \%$ porosity; it results in high air permeability [15]. Therefore, respirators allow achieving balance between filtration and air permeability. Respirators can be equipped with an exhale valve or be manufactured without it; they can be non-reusable (NR) or reusable ones (R).

Respirators from FFP1 category provide rather low-grade filtration. Respirators from FFP2/N95 and FFP3 categories are recommended by the WHO, the RF Public Healthcare Ministry and US Centers for Disease Control and Prevention (CDC) as personal protective equipment for medical workers who directly provide aid for patients with COVID-19 under conditions that involve virus aerosols formation in the air $^{3}[16,17]$.

In Russia requirements to respirators are stipulated by the State Standard ${ }^{4}$.

Face shields are protective screens made of transparent plastic; a shield looks like a plate that is rounded at its edges and can be fixed to a head. They are comfortable to wear and easy to clean, able to reduce autoinoculation due to not touching a person's face, they provide efficient protection from direct con- tacts with drops due to blocking initial forward movement of a liquid jet [18]. However, thrown out drops can move around a screen relatively easily and spread over a large area depending on ambient conditions [19].

The WHO recommends shields to be used in case face masks are not available; to provide comfortable communication between people when it is necessary to see a face of a person one is talking to; or they can be recommended to people who can't wear face masks due to various reasons (for example, mentally disabled people, people with development disorders, people suffering from deafness or hearing loss, and children as well) [10].

Criteria that allow defining a product as a medical one are approved on by the Eurasian Economic Commission ${ }^{5}$. The document stipulates that if a product is made by its manufacturer to be used in medical conditions to solve specific medical tasks it can be defined as a medical one. Otherwise, masks and respirators used to protect the respiratory organs cannot be defined as medical equipment and there are no unified regulatory requirements fixed for them. Such products are not subject to obligatory confirmation of their conformity with the existing standards ${ }^{6}$.

A medical mask is protective equipment that covers the nose and the mouth and provides a barrier that minimizes direct transmission of infection agents between medical personnel and patients?

According to the WHO, medical masks are medical products; they belong to «personal protective equipment» category and are subject to obligatory certification [10]. In the USA

\footnotetext{
${ }^{3}$ Temporary methodical guidelines. Prevention, diagnostics, and treatment of a new coronavirus infection (COVID-19). Version 9 (26.10.2020). The RF Public Healthcare Ministry Publ., 2020, 235 p. (in Russian).

${ }^{4}$ GOST 12.4.294-2015. Personal respiratory protective equipment. Filtrating half masks for protection from aerosols. KODEKS: an electronic fund for legal and reference documentation. Available at: http://docs.cntd.ru/document/1200121996 (03.02.2021) (in Russian).

${ }^{5}$ On criteria allowing to define a product as a medical one within the Eurasian Economic Union: Recommendations issued by the EAEC Board on November 12, 2018 No. 25. KODEKS: an electronic fund for legal and reference documentation. Available at: http://docs.cntd.ru/document/551663485 (03.02.2021) (in Russian).

${ }^{6}$ Code of Federal Regulations (annual edition). Title 21 - Food and Drugs. Chapter I - food and drug administration, department of health and human services (continued). Subchapter H - Medical devices. Part 878 - General and plastic surgery devices. U.S. Food and Drug Administration. Available at: http://docs.cntd.ru/document/551663485 (03.02.2021).

7 GOST 58396-2019. Medical masks. Requirements and testing procedures. KODEKS: an electronic fund for legal and reference documentation. Available at: http://docs.cntd.ru/document/1200163559/ (03.02.2021) (in Russian).
} 
medical masks manufacturing is regulated according to the requirements fixed in the codified collection of the basic regulations and orders issued by the US Federal executive authorities ${ }^{5}$.

In Russia it is conventional to divide masks into two types, I and II, depending on how efficiently they provide bacterial filtration $^{6}$. Type II masks can be conditionally divided into two sub-types (II and IIR) depending on how resistant a mask is to sprays. Type I medical masks are used by patients in order to reduce risks of infection spread especially during epidemics and pandemics. Type II masks are predominantly used by qualified medical staff in operating rooms or other medical rooms with similar requirements to them. Type IIR masks are used by medical experts in laboratories or at production facilities where completely sterile conditions are required; they can also be used in operating rooms to provide antiseptic protection for a patient.

To make such masks, either non-woven SMS (spunbond / meltblown / spunbond) material or SS (spunbond / spunbond) material is used; or they can be made of cotton gauze. The latter variant is usually used to reduce contagion risks for population beyond medical organizations. Medical masks are non-reusable medical products and it is recommended to change them as frequently as every $2-3$ hours $^{8}$.

The WHO recommends wearing medical masks in medical organizations in case there are no procedures involving aerosols formation. When considering an issue whether medical masks should be worn by people in everyday conditions, decision-makers should use an approach based on risk assessment procedures. Thus, medical masks are recommended to be worn by people who are older than 60 or people with concomitant diseases in case it is impossible to keep a safe 1-meter distance. They are also recommended to people who take care of or live together with people with assumed or confirmed COVID-19 diagnosis or in case they have to be in the same room with such people regardless of infection symptoms being apparent or absent [10].

Non-medical masks are sanitary-hygienic products made of various woven and nonwoven materials.

According to the WHO requirements, nonmedical masks are to be made of not fewer than 3 layers, the internal one being a hydrophilic material (for example, cotton or a mixed fabric containing cotton); the outer layer should be a hydrophobic material (for example, polypropylene, polyester, or their mixture) that can protect a carriers' nose or mouth from contaminants penetrating them; the middle layer should be a hydrophobic synthetic non-woven material, polypropylene for example, or cotton, that can enhance filtrating capacities or retain spray particles. Masks can be reused after being washed in water with a detergent under a temperature being not lower than $60^{\circ} \mathrm{C}$, and it should be done at least once a day [16].

Non-medical masks are recommended by the WHO to be used by people as a barrier aimed at reducing risks of contagion with respiratory infections; in case people should spend some time in a poorly ventilated room regardless of whether they can keep a safe distance or not; or they should be worn in the street in case it is impossible to keep a safe distance being at least 1 meter [10].

But at the same time, the US Centers for Disease Control and Prevention recommend wearing self-made and «manufactured» woven masks (being made of at least 2 layers) that are efficiently ventilated to all people who are older than 2 in order to protect themselves and people around during a pandemic; they also recommend wearing bandanas and headgears and wearing a scarf, ski mask or a balaclava over a woven mask during a cold season. Masks with valves are not recommended since contaminated air is exhaled into the ambient environment; respirators are either not recom-

\footnotetext{
${ }^{8}$ Methodical guidelines 3.1/3.5.0172/1-20. Recommendation on use of personal protective equipment (including reusable one) for different categories of citizens in case there are risks of COVID-19 contagion. Moscow, The Federal Service for Surveillance over Consumer Rights Protection and Human Well-being Publ., 2020, 17 p. (in Russian).
} 
mended since they are subject to obligatory registration and are to be worn by medical personnel; shields are not recommended since their efficiency has not been properly examined [17].

To sum up all the properties described above, we can spot out the following groups of respiratory protective equipment:

Respirators: non-woven (polypropylene), non-sterile, for adults, 6-8-layered ones, with different sizes, with or without a valve.

\section{Medical masks:}

- non-woven (spunbond / meltblown), non-reusable ones with or without a bactericide layer: non-sterile 3-layered (Type I and II); sterile 4-layered (Type IIR with additional sprayresistant layer);

- woven cotton (gauze, gauze / madapollam), non-sterile: non-reusable, 4-layered; reusable, 5-10-layered.

Non-medical masks: 1-4-layered, non-sterile, for adults with different sizes / for children;

- non-woven (spunbond / meltblown) non-reusable;

- woven reusable: cotton (honeycomb fabric, gauze, coarse calico, calico); synthetic (neoprene, polyester/spandex).

Face shields: plastic ones, reusable, for adults / for children.

If assessed as per efficiency of filtration fixed by regulatory standards, respiratory protective equipment is distributed in the following way (Table 1).
Table 1

Respiratory protective equipment distributed as per filtrating efficiency

\begin{tabular}{|c|c|}
\hline Mask type & $\begin{array}{l}\text { Filtration } \\
\text { efficiency in \% } \\
\text { standard given }\end{array}$ \\
\hline FFP1/KN90 respirator* & $\begin{array}{l}\text { not lower than } 80^{9} \\
\text { not lower than } 94^{10} \\
\text { not lower than } 90^{11}\end{array}$ \\
\hline $\begin{array}{l}\text { FFP2/KN95/N95/DS/DL2/ KF94 } \\
\text { respirator * }\end{array}$ & $\begin{array}{l}95^{12} \\
94^{13} \\
\end{array}$ \\
\hline FFP3/KN100/N99/N100 respirator * & $\begin{array}{c}99^{14} \\
97 ; 99^{15}\end{array}$ \\
\hline Non-woven medical mask Type I** & not lower than $95^{16}$ \\
\hline $\begin{array}{l}\text { Non-woven medical mask Type II } \\
\text { and IIR** }\end{array}$ & not lower than $98^{16}$ \\
\hline Non-medical mask ${ }^{* *}$ & not lower than $70^{17}$ \\
\hline
\end{tabular}

Note :

* means efficiency of filtration regarding aerosol particles sized $0.3 \mu \mathrm{m}(\mathrm{NaCl}$ particles);

** means bacterial filtration efficiency.

\section{Analysis of respiratory protective equip-} ment market in Russia. As we can see from the above review, masks differ as per their structure, number of layers and their density, efficiency, and mode of their use.

We examined marker offers made by different masks manufacturers using "Yandex Market», a popular service that helps consumers select goods or products. In December 2020 there were data on 838 various types of RPE being sold on the marker; most units were 3-layered ones (Table 2).

\footnotetext{
9 National Institute for Occupational Safety and Health (NIOSH). NIOSH Guide to the Selection and Use of articulate Respirators. Department of Health and Human Services (DHHS) NIOSH publication number 96-101, 1996; EU Standard EN149: $2001+\mathrm{A} 1$.

${ }^{10}$ Gost 12.4.294-2015. Personal respiratory protective equipment. Filtrating half masks for protection from aerosols.

11 The Chinese standard GB 19083.

12 National Institute for Occupational Safety and Health (NIOSH). NIOSH Guide to the Selection and Use of articulate Respirators. Department of Health and Human Services (DHHS) NIOSH publication number 96-101, 1996; GOST 12.4.294-2015. Personal respiratory protective equipment. Filtrating half masks for protection from aerosols; CEN, E., 2001. 149: 2001 norm: Respiratory protective devices-Filtering half masks to protect against particles Requirements, testing, marking. European Committee for Standardization; The Chinese standard GB 19083.

13 The EU standard EN149: 2001+A1.

${ }^{14}$ National Institute for Occupational Safety and Health (NIOSH). NIOSH Guide to the Selection and Use of articulate Respirators. Department of Health and Human Services (DHHS) NIOSH publication number 96-101, 1996; GOST 12.4.294-2015. Personal respiratory protective equipment. Filtrating half masks for protection from aerosols; The EU standard EN149: 2001+A1

15 The Chinese standard 19083; National Institute for Occupational Safety and Health (NIOSH). NIOSH Guide to the Selection and Use of articulate Respirators. Department of Health nd Human Services (DHHS) NIOSH publication number 96-101, 1996.

${ }^{16}$ GOST R 58396-2019. Medical masks.

${ }^{17}$ AFNOR. 2020. SPEC S76-001: Masque barrière. Guide d'exigenceminimales, de méthoded'essais, de confection etd'usage. Available at: https://masques-barrieres.afnor.org/home/telechargement (04.06.2020).
} 
Table 2

Masks offered to consumers on «Yandex Market» web-site

\begin{tabular}{|c|c|c|c|c|c|c|c|}
\hline \multirow{2}{*}{ Mask type } & \multicolumn{6}{|c|}{ Number of layers } & \multirow{2}{*}{ Total } \\
\hline & 1 & 2 & 3 & 4 & 5 & 6 & \\
\hline Non-reusable & 1 & 9 & 336 & 6 & - & & 354 \\
\hline Reus: & 12 & 192 & 96 & 6 & 28 & & 339 \\
\hline & 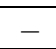 & 39 & 96 & 0 & - & & 145 \\
\hline Total & 13 & 240 & 528 & 20 & 28 & 9 & 838 \\
\hline
\end{tabular}

We failed to find out what masks out of those offered on the site were medical ones since it was impossible to understand what manufacturers meant when they called their products «medical» or «non-medical» masks. They used a huge variety of descriptions such as medical mask, protective medical mask, respirator, protective respirator, protective non-medical mask, hygienic mask, protective hygienic mask, hygienic common mask, gauze hygienic mask, protective mask, sanitaryhygienic mask, etc.

Having analyzed the State Medical Equipment and Organizations (Private entrepreneurs) Register of the Federal Service for Surveillance in Public Healthcare that contained data on economic entities producing medical products, we established that there were 201 masks that were officially registered (taken as in December 2020). All the registered masks are divided into medical ones and respirators but a number of layers in them is not always specified (Table 3 ).

As we can see from data in tables 1 and 2, less than one quarter $(24 \%)$ of masks being sold on the market are officially registered by the Federal Service for Surveillance in the Public Healthcare and are allowed to be distributed on the RF territory.

Due to 2020 COVID-19 pandemic a simplified registration procedure was introduced at the initial stage in the process and it resulted in a drastic increase in number of registered masks (Table 4) 16 registration certificates were annulled by December 2020.

Therefore, our market analysis revealed that all the existing RPE types were being distributed on the market in Russia but data on the marketed products were rather controver- sial. Manufacturers rarely classify their products correctly (whether they are medical or non-medical ones); not all of them provide data on a registration certificate; a lot of manufacturers do not even give data on the structure and materials their RPE is made of. As a rule, any description contains data on only two properties: number of layers and whether RPE is non-reusable or reusable one. RPE is not always marked properly and marking does not confirm data stated in an advertisement for a product on the web-site.

Table 3

Masks registered in the State Medical Equipment Register *

\begin{tabular}{|c|c|c|c|c|c|c|c|c|}
\hline \multirow[b]{2}{*}{ Mask type } & \multicolumn{7}{|c|}{ Number of layers } & \multirow[b]{2}{*}{ Total } \\
\hline & 1 & 2 & 3 & 4 & 5 & 6 & $\begin{array}{c}\text { Not } \\
\text { specified }\end{array}$ & \\
\hline $\begin{array}{l}\text { Non-reusable } \\
\text { medical }\end{array}$ & 2 & 21 & 107 & 24 & 3 & 2 & 32 & 191 \\
\hline $\begin{array}{l}\text { Reusable } \\
\text { medical }\end{array}$ & - & - & - & 1 & & 1 & 2 & 4 \\
\hline Respirators & - & - & - & - & 2 & - & 4 & 6 \\
\hline Total & 2 & 21 & 107 & 25 & 5 & 3 & 38 & 201 \\
\hline
\end{tabular}

$\mathrm{N}$ o t e : * means that the analysis did not cover masks included into protective clothing sets and firstaid kits.

Table 4

Number of registration certificates issued and annulled over 2017-2020

\begin{tabular}{|c|c|c|c|}
\hline Year & $\begin{array}{c}\text { Certificates } \\
\text { issued }\end{array}$ & $\begin{array}{c}\text { Certificates for more } \\
\text { than 1 type of masks }\end{array}$ & $\begin{array}{c}\text { Certificates } \\
\text { annulled }\end{array}$ \\
\hline 2017 & 5 & 1 & 0 \\
\hline 2018 & 7 & 1 & 0 \\
\hline 2019 & 3 & 2 & 0 \\
\hline 2020 & 159 & most & 16 \\
\hline
\end{tabular}

Respiratory protective equipment classification. Since RPE tends to have variable properties, it seems advisory to develop its classification.

Bearing in mind that RPE has different filtration efficiency, fitness to a face, number of layers, and can be made of different materials, and also taking into account recommendation issued by the WHO experts and the RF Public Healthcare Ministry, we suggest classifying RPE as per protection efficiency as follows (Table 5). 
Table 5 properties stipulated by the standards on prod-

RPE classification as per efficiency of protection from respiratory infections*

\begin{tabular}{|c|c|c|}
\hline \multicolumn{2}{|c|}{ Protection efficiency } & Respiratory protective equipment \\
\hline High & \multirow{3}{*}{$\begin{array}{l}\text { Additional } \\
\text { protection } \\
\text { from virus } \\
\text { aerosol }\end{array}$} & $\begin{array}{l}\text { FFP3/KN100/N99/N100 respira- } \\
\text { tors }\end{array}$ \\
\hline Average & & $\begin{array}{l}\text { FFP2/KN95/N95/DS/DL2/KF94 } \\
\text { respirators }\end{array}$ \\
\hline \multirow[b]{2}{*}{$\begin{array}{l}\text { Below } \\
\text { average }\end{array}$} & & FFP1respirators \\
\hline & \multicolumn{2}{|c|}{\begin{tabular}{|l|} 
Medical masks: \\
Non-woven, Type IIR \\
Type II \\
Type I \\
Woven gauze masks \\
\end{tabular}} \\
\hline Low & \multicolumn{2}{|c|}{$\begin{array}{l}\text { Non-medical masks: } \\
\quad \text { Non-woven, woven (cotton, synthetic) }{ }^{1} \\
\end{array}$} \\
\hline $\begin{array}{l}\text { Extremely } \\
\text { low }\end{array}$ & \multicolumn{2}{|c|}{ Face shields ${ }^{2}$} \\
\hline
\end{tabular}

Note :

* means RPE is given in a descending order regarding its protective properties;

${ }^{1}$ means protective properties are directly proportionate to a number of layers in a mask provided it is used properly (proper duration of use, disinfection procedures for reusable masks are accomplished properly);

2 means when they are worn separately, not combined with other RPE.

The suggested classification allows developing a unified approach to providing data on a product for a consumer especially when small lots are bought on retail market or in the Internet; these data should specify all the uct marking (material, number of layers, conditions of use, etc.) and protection efficiency of a product that is sold on the market.

\section{Conclusions:}

1. We have established that it is vital to develop precise criteria for determining protective efficiency when RPE is produced and sold.

2. It is necessary to develop a unified approach to «medical» and «non-medical mask» concept including situations when data are provided for a customer.

3. Only $24 \%$ of all RPE being sold on the consumer market in the RF is officially registered within the State Medical Equipment and Organizations (Private entrepreneurs) Register of the Federal Service for Surveillance in Public Healthcare.

4. We have developed RPE classification as per efficiency of protection from respiratory infections; this classification takes into account filtration efficiency, fitness to a face, number of layers, a material a mask is made of, and recommendations issued by the WHO and the RF Public Healthcare Ministry

Funding. The research was not granted any financial support.

Conflict of interests. The authors declare there is no any conflict of interests.

\section{References}

1. COVID-19: One year later - WHO Director-General's New Year message. World health organization, 2020. Available at: https://www.who.int/ru/news/item/30-12-2020-covid-19-anniversary-andlooking-forward-to-2021 (10.02.2021).

2. WHO Coronavirus Disease (COVID-19) Dashboard. World health organization, 2020. Available at: https://covid19.who.int/ (10.02.2021).

3. Coronavirus disease (COVID-19): Herd immunity, lockdowns and COVID-19. World health organization, 2020. Available at: https://www.who.int/ru/news-room/q-a-detail/herd-immunity-lockdownsand-covid-19 (10.02.2021).

4. Transmission of SARS-CoV-2: implications for infection prevention precautions: scientific brief, 09 July 2020. World health organization, 2020. Available at: https://apps.who.int/iris/handle/10665/333114 (10.02.2021).

5. Zhang R., Li Y., Zhang A.L., Wang Y., Molina M.J. Identifying airborne transmission as the dominant route for the spread of COVID-19. Proceedings of the National Academy of Sciences, 2020, vol. 117, no. 26, pp. 14857-14863. DOI: 10.1073/pnas.2009637117

6. Chu D.K., Akl E.A., Duda S., Yaacoub S., Solo K., Schünemann H.J. Physical distancing, face masks and eye protection to prevent person-to-person transmission of SARS-CoV-2 and COVID-19: a systematic review and meta-analysis. Lancet, 2020, vol. 395, no. 10242, pp. 1973-1987. DOI: 10.1016/S0140-6736(20)31142-9 
7. Chiu N.-C., Chi H., Tai Y.-L., Peng C.-C., Tseng C.-Y., Chen C.-C., Tan B.F., Lin C.-Y. Impact of wearing masks, hand hygiene, and social distancing on influenza, enterovirus, and all-cause pneumonia during the coronavirus pandemic: Retrospective national epidemiological surveillance study. J. Med. Internet Res, 2020, no. 22, pp. e21257. DOI: 10.2196/21257

8. Abboah-Offei M., Salifu Y., Adewale B., Bayuo J., Ofosu-Poku R., Opare-Lokko E.B.A. A rapid review of the use of face mask in preventing the spread of COVID-19. Int J. Nurs. Stud. Adv., 2021, no. 3, pp. 100013. DOI: 10.1016/j.ijnsa.2020.100013

9. Clapp P.W., Sickbert-Bennett E.E., Samet J.M., Berntsen J., Zeman K.L., Anderson D.J., Weber D.J., Bennett W.D. Evaluation of cloth masks and modified procedure masks as personal protective equipment for the public during the COVID-19 pandemic. JAMA Internal Medicine, 2020, no. 10, pp. e208168. DOI: 10.1001/jamainternmed.2020.8168

10. Primenenie masok v usloviyakh COVID-19. Vremennye rekomendatsii 1 dekabrya $2020 \mathrm{~g}$. [Mask use in the context of COVID-19. Interim guidance. December 1, 2020]. World health organization, Geneva, 2020, 28 p. (in Russian).

11. Eikenberry S.E., Mancuso M., Iboi E., Phan T., Eikenberry K., Kuang Y., Kostelich E., Gumel A.B. To mask or not to mask: Modeling the potential for face mask use by the general public to curtail the COVID-19 pandemic. Infect. Dis. Model., 2020, no. 5, pp. 293-308. DOI: 10.1016/j.idm.2020.04.001

12. Ngonghala C.N., Iboi E., Eikenberry S., Scotch M., MacIntyre C.R., Bonds M.H., Gumel A.B. Mathematical assessment of the impact of non-pharmaceutical interventions on curtailing the 2019 novel Coronavirus. Math Biosci, 2020, no. 325, pp. 108364. DOI: 10.1016/j.mbs.2020.108364

13. Stutt R., Retkute R., Bradley M., Gilligan C.A., Colvin J. A modelling framework to assess the likely effectiveness of facemasks in combination with «lock-down» in managing the COVID-19 pandemic. Proc. R. Soc. A. Math. Phys. Eng. Sci., 2020, vol. 476, no. 2238, pp. 0376. DOI: 10.1098/rspa.2020.0376

14. Worby C.J., Chang H.H. Face mask use in the general population and optimal resource allocation during the COVID-19 pandemic. Nat. Commun., 2020, vol. 1, no. 1, pp. 4049. DOI: 10.1038/s41467-020-17922-x

15. Liao L., Xiao W., Zhao M., Yu X., Wang H., Wang Q., Chu S., Cui Y. Can N95 Respirators Be Reused after Disinfection? How Many Times? ACS Nano, 2020, no. 14, pp. 6348-6356. DOI: 10.1021/acsnano.0c03597

16. Primenenie masok v kontekste COVID-19. Vremennye rekomendatsii 5 iyunya 2020 g. [Mask use in the context of COVID-19. Interim guidance. June 5, 2020]. World health organization, Geneva, 2020, 20 p. (in Russian).

17. CDC Use Masks to Slow the Spread of COVID-19. Centers for Disease Control and Prevention, 2020. Available at: https://www.cdc.gov/coronavirus/2019-ncov/prevent-getting-sick/diy-clothface-coverings.html (10.02.2021).

18. Kumar S. The perspective of fluid flow behavior of respiratory droplets and aerosols through the facemasks in context of SARS-CoV-2. Phys. Fluids., 2020, vol. 32, no. 11, pp. 111301-111315. DOI: $10.1063 / 5.0029767-15$

19. Perencevich E.N., Diekema D.J., Edmond M.B. Moving personal protective equipment into the community: Face shields and containment of COVID-19. Jama, 2020, no. 323, pp. 2252. DOI: 10.1001/jama.2020.7477

Shashina E.A., Isiutina-Fedotkova T.S., Makarova V.V., Gruzdeva O.A., Mitrokhin O.V. Approaches to analyzing efficiency of respiratory protective equipment as a way to reduce health risks during COVID-19 pandemic. Health Risk Analysis, 2021, no. 1, pp. 151-158. DOI: 10.21668/health.risk/2021.1.16.eng

Received: 25.02 .2021

Accepted: 03.03.2021

Published: 30.03 .2021 


\title{
ANALYTICAL REVIEWS
}

UDC 579.61

DOI: $10.21668 /$ health.risk/2021.1.17.eng

Review

\section{GUT MICROBIOTA AS RISK FACTOR CAUSING OBESITY IN CHILDREN}

\author{
P.Yu. Petrova, A.D. Aga, E.S. Trapeznikova, E.V. Budanova
}

I.M. Sechenov First Moscow State Medical University, 8/1 Trubetskaya Str., Moscow, 119048, Russian Federation

Nowadays obesity resulting from abnormal or excessive fat deposits in a body has become a true epidemic. Risk factors that cause the disease include improper lifestyle, hereditary predisposition, as well as metabolic activity of gut microbiota. Research works performed over the last decades indicate that microbes that create colonies in human intestines play a significant role in maintaining proper metabolism. There is a correlation between disorders in gut microbiota structure and immune disorders, elevated susceptibility to infections, and obesity. There is more and more evidence that gut microbiota and its overall bacterial genome exert their influence on nutrients assimilation and regulate energy metabolism and fat accumulation.

Certain differences were detected in microbiota gut structure in children and adults with obesity and people with proper body mass index. Delivery and feeding are among key factors influencing gut microbiota formation in a child. Thus, research results indicate that natural birth, as opposed to cesarean section, can prevent obesity occurrence in a child. Breast-feeding also makes a substantial contribution into development of an infant since breast milk is balanced food that provides optimal metabolism in an infant's body and helps creating proper gut microbiota. At the same time, according to data obtained via numerous research works, artificial feeding can be related to obesity occurrence in future.

Ways to fight obesity include medication therapy, dietary nutrition, physical activity as well as bariatric surgery; the latter is nowadays considered to be the most efficient procedure on the matter. Reduction in body mass via influencing gut microbiota is a promising trend in research in the sphere. Despite there are objective data on benign effects produced by probiotics and prebiotics on gut microbiota, experts haven't been able to reach agreement on their efficiency yet.

Key words: obesity, gut microbiota, obesity in children, probiotics, prebiotics, Akkermansia muciniphila, feeding, delivery, nutrition habits.

Obesity is a multi-factor disorder that develops due to complicated interaction between genetic and environmental factors creating an imbalance between energy input and consumption [1]. The disease is among the most acute health problems in the $21^{\text {st }}$ century. Obesity-related metabolic disorders do not only exert adverse effects on all organs and systems in a human body but also result in significant burden on a public healthcare system in any country $[2,3]$.

As per data collected in 2016, more than 1.9 billion people aged 18 and older had overweight and 600 million out of them suffered from obesity worldwide. Number of newborns and toddlers (aged from 0 to 5) who had overweight or obesity increased from 32 million in 1990 to 38 million in

(c) Petrova P.Yu., Aga A.D., Trapeznikova E.S., Budanova E.V., 2021

Polina Yu. Petrova - undergraduate student (e-mail: petrova.polina.13@mail.ru; tel.: +7 (960) 468-87-86; ORCID: https://orcid.org/0000-0002-3357-9093).

Alexandra D. Aga - undergraduate student (e-mail: alexandra.aga99@gmail.com; tel.: +7 (916) 279-63-06; ORCID: https://orcid.org/0000-0002-9399-407X).

Ekaterina S. Trapeznikova - undergraduate student (e-mail: trapeznikova_01@icloud.com; tel.: +7 (952) 524-90-98; ORCID: https://orcid.org/0000-0003-1274-4667).

Elena V. Budanova - Candidate of Medical Sciences, Associate Professor at the Department for Microbiology, Virology and Immunology (e-mail: e.v.budanova@mail.ru; tel.: +7 (925) 704-39-09; ORCID: http://orcid.org/0000-0003-1864-5635). 
2019 all over the world. More than $60 \%$ children who have overweight prior to pubescence enter their adult life still suffering from it [4]. Obesity both among children and adults is to a great extent related to risk factors that cause cardiovascular diseases, type II diabetes mellitus, immune pathologies, oncologic diseases, orthopedic problems, and mental disorders $[5,6]$.

Interaction between multiple factors that result in obesity occurrence has not been studied in depth [6]. Thus, for example, certain genes are known to take part in formation of predisposition to overweight. More and more reliable scientific studies confirm that gut microbiota plays a key role in obesity occurrence.

Microbiota is a cluster of all the microorganisms that are necessary for proper functioning of a human body [7]. More than 100 trillion $\left(10^{14}\right)$ microcells are in symbiosis with a human body and make their contribution into maintaining metabolic health [8]. Bacteria in human guts perform several functions such as digestive, protective, immune-modulating, detoxifying, metabolic, etc. They play a significant role in maintaining carbohydrate, lipid, and protein metabolism. Given that, an issue related to a role played by microbiota in various diseases development becomes especially significant Thus, obesity as $\ll 21^{\text {st }}$ century pandemic» is paid great attention by scientists all over the world.

The aim of this review was to assess a potential role gut microbiota plays in obesity pathogenesis in children.

Data and methods. To achieve our aim, we used data from papers mentioned in Scopus and NCBI Medline databases.

Results and discussion. Risk factors that cause obesity. There are multiple factors that can cause overweight and obesity. Some are non-modifiable such as age and sex, family history or hereditary predisposition. But other factors, for example, lifestyle, can be influenced. Should a person start to pursue a healthy lifestyle, it can reduce risks that overweight or obesity might occur [9].
«Healthy lifestyle» as a concept includes eating patterns and habits, physical activity, emotional and mental health, and proper healthy sleep. Balanced nutrition that takes into account calories in consumed food depending on a person's age, sex, and physical activity should determine proper eating behavior [10]. Stress is another risk factor that can cause obesity since it exerts adverse impacts on the brain and induces stress hormones production. For instance, cortisol maintains control over hunger and energy balance [11].

Multiple research works have revealed that there is a correlation between lack of sleep and an increase in body mass index (BMI). It has been shown that sleep deprivation results in greater levels of hormones that make a person feel hunger and in lower levels of hormones that are responsible for satisfying this hunger; fatigue also increases thus leading to overall lower physical activity[12]. Additional hours during which a person is awake provide more opportunities for eating $[12,13]$.

Genetic studies reveal that predisposition to overweight can be inherited. Parental genes can influence amount of fat that is deposited in a human body as well as on the way of its distribution. FTO gene (fat mass and obesity associated) is one of such genes; it codes FTO protein that is involved into energy metabolism and influences metabolism as a whole [14].

Obesity can occur at any age, even among small children. As a person grows older, hormonal changes and less active lifestyle result in only greater risks of its occurrence. Besides, at an older age metabolism becomes less active, therefore, demand for calories goes down, and fighting against overweight becomes more difficult. Women have overweight more frequently than men [15].

Race and ethnic group can also determine body weight. For example, obesity among adults is more frequent in Negroids people and less frequent in Caucasians. At the same time, BMI among Asian men and 
women is within physiological standards in most cases [16].

Pregnancy provokes body weight growth which is considered to be normal within certain limits. Some women face a serious problem when they try to lose weight after delivery due to slower metabolism and changes in their hormonal state [17].

All the above mentioned risk factors that can cause obesity are well-known. However, recently researchers have started to pay attention to gut microbiota. Bacteria participate directly in metabolic processes since they increase quantity of energy obtained from diet and regulate fat tissue formation [18]. Changes in gut microbiota structure are considered to be a risk factor [19]. Given that, a question arises: how does gut microbiota influence obesity development?

New developments in examining gut microbiota structure in people with obesity. Since researchers discovered a role played by gut microbiota in metabolism regulation in a host's body, scientists have been paying attention to two main bacteria phyla Firmicutes and Bacteriodetes. Their quantitative ratio distortion can underlie obesity pathogenesis. It was revealed that people suffering from obesity had Bacteroidetes bacteria in low quantity and Firmicutes bacteria in high quantity [20]. Later researchers found out that changes in microbiota composition occurring at lower taxonomic levels could also be related to this metabolic disorder. Therefore, changes in quantity of bacteria belonging to a specific genus or even species can be more reliable markers of dysbiosis that can result in obesity than a disproportion in Firmicutes / Bacteroidetes ratio [20].

Researchers are discussing various mechanisms that could provide an insight into a correlation between gut microbiota structure and obesity development [21]. One of them is gut microbes being able to derive energy from indigestible polysaccharides creating an additional source of calories for a host's body. Besides, gut microbiota bacteria are proven to be able to regulate lipopoly- saccharides (LPS) content in blood and these substances induce moderate chronic systemic inflammation that creates favorable conditions for obesity and diabetes occurrence. The third mechanism is based on a fact that gut microbiota in a human body is able to regulate expression of genes in a host's body that are related to energy preservation and consumption [21].

Proteobacteria phylum is thought to be related to dysbiosis that can also result in such metabolic disorders as obesity [22]. It happens due to an increase in proteobacteria quantity correlating with lower mucus production that leads to damage to the gut protective barrier and non-specific inflammation [22, 23].

In this respect it is interesting to look at Faecalibacterium prausnitzii bacteria that belong to Firmicutes phylum, Clostridia class in Ruminococcaceae family and are leading butyrate producers in the guts $[24,25]$. Butyrate is a short-chain fatty acid (SCFA). It is a main energy source for colonocytes and produces protective effects regarding colorectal cancer and inflammatory gut diseases. This SCFA is able to reduce inflammatory reactions in the gut mucosa due to its ability to inhibit activation of NF- $\kappa$ B transcription factor (a universal transcription factor that controls expression of genes related to immune response, apoptosis, and cellular cycle), as well as due to PPAR yactivation and IFN- $\gamma$ inhibition. $F$. prausnitzii bacteria have additional antiinflammatory properties due to their ability to maintain a cytokine profile with very low secretion of IL-12, IFN- $\gamma$ anti-inflammatory cytokines and high secretion of IL-10 antiinflammatory cytokine [25]. Therefore, we can conclude that F. Prausnitzii bacteria are able to produce anti-inflammatory effects on the gastrointestinal tract due to producing butyrate in great quantity and being able to maintain a certain cytokine profile; so, a decrease in their quantity in children's gut microbiota can be indirectly related to biological obesity. Moreover, these bacteria were offered as a biomarker to be used in gut diseases diagnostics $[25,26]$. 
Lactobacilli (Firmicutes phylum) are grampositive, acidogenic, and aciduric bacteria; their content in a body is greatly influenced by a person's eating habits [21]. Impacts exerted by Lactobacilli on body weight growing are considered to be depending on their species. For example, high $L$. reuteri content correlates with high BMI [27] whereas such phyla as L. paracasei and L. plantarum can protect from body weight growing due to their ability to produce bacteriocins that prevent an increase in contents of dysbiosis-inducing pathogens $[6,22,28]$.

Bacteria from Fusobacterium genus are opportunistic pathogenic and their content can be elevated in people who suffer from obesity [22].

Akkermansia muciniphila bacterium is the only one cultivated gut bacterium belonging to Verrucomicrobia phylum [29]. Akkermansia are mucin-degrading bacteria and they influence metabolic processes in a host's body. They participate in maintaining the gut barrier integrity and keep gut microbiota structure in eubyosis that makes for normal body weight preservation $[6,22,30]$. It is interesting to note that lower A. Muciniphila content was detected in patients with gut inflammations (predominately, ulcerous colitis) and metabolic disorders; it allows assuming that these bacteria can have certain antiinflammatory properties [30].

Clostridium leptum, together with fecal bacteria, belongs to Clostridium IV cluster; this bacterium ferments unabsorbed sugar and dietary fiber and produces SCFA [21]. SCFA (butyrate, propionate, and acetate) can serve as an energy source both for other bacteria and a host's body as a whole (approximately $10 \%$ of all the energy) as well as participate in maintaining proper functioning of gut epithelium [20].

Another representative from this cluster, Eubacterium hallii, is able to utilize dextrose and such intermediate fermentation products as acetate and lactate thus creating butyrate and hydrogen. Lactate accumulation is thought to be related to some gut diseases and malabsorption syndrome [31].
Methanobrevibacter smithii is a one-celled microorganism that belongs to Archaea domain and makes for carbon and hydrogen turning into methane; it also produces SCFA [32]. Researchers think that a basic role $M$. Smithii plays in a body is maintaining balanced hydrogen contents in the guts. Changes in M. Smithii concentration in the guts are assumed to create higher risks of obesity and inflammatory diseases in the gastrointestinal tract such as irritable gut syndrome, colorectal cancer, or diverticular disease [32].

Microbiota in children with obesity. It is highlighted in scientific works that child obesity is a multi-factor disease that can be caused by non-optimal microelements content in nutrition rations together with low physical activity. The disease might also be caused by genetic, endocrine, and psychoemotional factors. Besides, recent clinical studies indicate that there are significant differences in gut microbiota structure in children with obesity and those with normal body weight.

Over recently ears multiple papers have been disproving a theory on the intrauterine medium being sterile since microbe traces are discovered in placenta and amniotic fluid $[5,33,34]$. Studies on infants' meconium have revealed bacteria in it, mostly enterococci and staphylococci [33, 34]. Multiple theories are now being discussed on how microbiota is being transferred from a mother to a child during pregnancy, and during the first months after birth it is still not very diverse [5]. It was discovered that significant changes in gut microbiota occurred in children aged from 9 to 18 months, especially when breastfeeding was gradually replaced with baby food [21]. Approximately at the age of 3 , a child's gut microbiota is relatively similar to that in adult people [5]. Therefore, childhood can provide a unique opportunity to interfere with gut microbiota in order to improve a child's health and to prevent certain diseases, obesity included [35].

Thousand bacteria belonging to Firmicutes phylum can be involved into body weight growing. Thus, for example, it was 
shown that increased quantities of $C$. leptum and $E$. hallii species together with a decrease in quantity of $F$. prausnitzii and $C$. difficile was related to obesity and overweight in infants, pre-school children and schoolchildren as well [36-39].

Bacteroidetes phylum mostly consists of gram-negative bacteria as opposed to predominantly gram-positive microorganisms of Firmicutes phylum. Three studies revealed a positive correlation between $B$. fragilis and obesity in children with high and moderate evidence. The research work performed by Vael et al. focused on a correlation between gut microbiota structure and BMI during the first three years of life [40]. It was shown that high $B$. fragilis concentrations in a three-week old infant highly correlated with high BMI during the first three years of life. This data was also confirmed in research works by Scheepers et al. and Ignacio et al. [40, 41].

Besides, several research works revealed that people with obesity tended to have lower quantity of bacteria from Bacteroides / Prevotella genera (gram-negative bacteria belonging to Bacteroidetes phylum) [21]. Bacteria from these two genera are representatives of standard gut microbiota; however, their excessive quantities are also related to gut inflammation that is mediated with anti-inflammatory cytokines released by Th17. It is necessary to accomplish further studies on certain bacteria species in order to explain this contradiction. But at the same time, studies that focused on the whole Bacteroidetes phylum revealed that their quantities and, consequently, Bacteroidetes/Firmicutes ratio were substantially lower in children with obesity against children with normal body weight; it probably can be considered a specific marker. It is important to note that such species / families as M. smithii, A. muciniphila, Bifidobacteriaceae which belonged to other bacteria phyla were also related to low BMI.

We should note that gut microbiota in an adult is predominantly represented by such phyla as Firmicutes, Bacteroidetes, Proteo- bacteria, Actinobacteria and Verrucomicrobia [22]. And Firmicutes and Bacteroidetes account for approximately $90 \%$ of all bacteria in gut microbiota of a healthy person. To compare microbiota parameters in children that are described above, let us draw your attention to Table that contains data on a gut microbe profile for a person with obesity taken from [22].

Content of various bacteria in people suffering from obesity [22]

\begin{tabular}{|l|c|}
\hline \multicolumn{1}{|c|}{ Bacteria } & $\begin{array}{c}\text { Content in adults } \\
\text { with obesity }\end{array}$ \\
\hline Firmicutes & Elevated \\
\hline Bacteroidetes & Decreased \\
\hline Firmicutes/Bacteroidetesratio & Elevated \\
\hline Akkermansia muciniphila & Decreased \\
\hline Proteobacteria & Elevated \\
\hline Faecalibacteriumprausnitzii & Decreased \\
\hline Fusobacterium & Elevated \\
\hline Methanobrevibactersmithii & Decreased \\
\hline Lactobacillus reuteri & Elevated \\
\hline
\end{tabular}

Influence exerted by delivery type on obesity occurrence and development in children. Delivery type is a factor that determines gut microbiota in newborns. Gut microbiota in infants who were born via cesarean section (CS) differs significantly from that in children who were born naturally [5, 42]. During natural delivery microorganisms that occur in a woman's birth canal, guts, and perineum create their colonies in an infant's gut. For example, such vaginal bacteria as Lactobacillus spp. and Prevotella spp. participate in creating infants' gut microbiota. And on the contrary, children born via CS are colonized with microbes from the environment (mother's skin, medical personnel, medical equipment, and other children) [42].

Various research works have shown that children born via CS have less diverse gut microbiota and their guts are less frequently colonized with such microorganisms as Bifidobacterium spp. and Bacteroides spp. but they tend to have $C$. difficile more frequently [42]. At the same time it is well known that bifidobacteria 
and bacteroids prevail in gut microbiota of children who were born naturally [43]. These bacteria make for immunity formation in infant children. Bifidobacteria prevent from obesity occurrence via different mechanisms; one of them is their ability to degrade human milk oligosaccharides (HMOs) into SCFA. Therefore, we can assume that CS-birth is related to risks of obesity occurrence in future.

Natural birth was shown to produce protective effects regarding various diseases; in its turn, CS can have remote consequences for health (obesity, bronchial asthma, allergy, and type I diabetes mellitus) [42]. Three metaanalyses revealed that children born via CS ran $33 \%$ higher risks of child obesity occurrence [44-46].

Some researchers think that low bifidobacteria quantities and high clostridia contents in children born via CS are caused by antibiotics intake since mothers have to take them prior to and after delivery in order to provide selective decontamination [47]. Besides, delivery via CS can be a reason that there is no lactation during the first hours after a child has been born as well as shorter breastfeeding period; it can lead to metabolic disorders in a child $[47,48]$.

There is an interesting procedure when children born via CS are exposed to their mothers' microflora. To do that, a swabbed sponge is used to transfer mother's vaginal liquids onto infant's mouth, face, and body directly after CS. The procedure is assumed to make for an infant's guts being colonized with «healthy» bacteria from a mother's body and prevent obesity occurrence in future. Several research works proved that oral, skin, and gut microbiota in CS-born children who underwent this procedure was similar to that in children who were born naturally [49].

Influence exerted by infant feeding on risks of obesity occurrence. There was a cohort study accomplished by Wallby et al. [50]; it focused on a role of breastfeeding in obesity and overweight prevention. 18 children were observed starting from birth and till they reached 4 years of age; their BMI and subcu- taneous fat percentage were estimated in dynamics. Infants were distributed into two groups; the first one were infants who were breastfed for less than 3 months since birth and the second one was made up of children who received breastfeeding for longer than 3 months since birth. BMI and subcutaneous fat percentage were identical in both groups. By an age of 3 months, infants form the first group had significantly higher values of both examined criteria against children from the second one; starting from the age of 6 months, BMI and subcutaneous fat percentage in the first group became higher than their physiological standard in most children in this group. By 3-4 years, obesity prevalence among children from the first group grew up by 3 times whereas there were only slight changes in the parameter in the second group (the difference between two groups was determined as statistically significant) [50]. Additional analysis revealed that «mother-related» factors exerted their influence on obesity risks in their children; these factors included mother's BMI being higher than 27, smoking and alcohol intake during pregnancy. Therefore, we can conclude that an early weaning combined with mother's overweight, bad habits, and low social status, are risks factors that can cause overweight and obesity in her children who were younger than 4 years old.

From pathophysiological point of view, breastfeeding determines dynamics of growth in a child's height and weight $[51,52]$. Research revealed that children who were breastfed had flatter curves showing their height and weight against children who were fed artificially. Breastfeeding is assumed to be a protective factor regarding obesity at older age [53]. Difference in height and weight dynamics is justified by elevation of insulin like growth factor (IGF-1) in blood plasma of children who receive artificial feeding [54]. It can possibly be caused by endocrine modulation that results from differences in the structure of biologically active substances in human milk as compared with artificial feeding mixes. In particular, breast milk has lower energy value and 
contains less protein but more fat in comparison with most feeding mixes based on milk substitutes [15]. Besides, it was established that breast milk contained bifidobacteria that could modulate an infant's microbiota thus producing a preventive effect regarding obesity occurrence.

When supplemental feeding is introduced into nutrition, overall energy consumption grows by $15-23 \%$ in children aged from 3 to 18 months who receive artificial feeding [55]. Besides, children who are fed with formulas consume by $20-30 \%$ more food each time they eat. They also tend to consume more food when they grow older [56]. And on the contrary, breast milk satisfies demands for energy better than artificial one; breast milk consumption goes down after solid food has been added into a ration as supplemental feeding [55]. Therefore, different feeding can influence a child's body weight: each additional 100 kilocalories per day that were consumed during 4 months were related to higher probability of overweight in $46 \%$ cases among 3-year old children [57].

We should note that formulas are usually made as per recipes that prescribe higher protein contents; usually this contents are by $50-80 \%$ higher than in breast milk [57]. This discrepancy is assumed to be a major cause of height and weight differences between naturally fed children and artificially fed ones [58]. According to «early protein hypothesis», when protein is introduced with food in high quantities into a child's body, it produces significant effects on a child's growth thus increasing a probability that obesity might occur in future [59]. There was a multi-centered study on child obesity when healthy children who were artificially fed got only cow milk during their first year and then a mix with low or high protein contents accordingly. A share of children with greater body weight was higher in a group where children got food with higher protein contents [60].

As opposed to proteins, fat contents are higher in breast milk than in baby formulas [61].
Besides, breast milk contains long-chain polyunsaturated fatty acids in higher concentrations [62]. However, no researcher has yet been able to reveal a correlation between fat consumption in infancy and early childhood and body weight growth at older ages.

Apart from all these crucial differences in nutritional substrates between breast milk and baby formulas, we should also remember that breast milk structure changes dynamically over lactation period. Therefore, there is a close connection via feeding «from a mother to a child». Due to this connection a child's energy demands can be regulated, for example, via changing frequency and duration of feeding and it influences weight dynamics [50]. It is assumed that a choice of breast feeding results in more efficient selfregulation of consumed food quantity by a newborn [62].

Besides, breast milk contains hormones that impose certain limitations on energy metabolism and food consumption by an infant. For example, such hormones as leptin, insulin, adiponectin, and obestatin can activate mechanisms that regulate hunger depending on energy demands via epigenetic processes [63]. Besides, positive effects produced by breast feeding on obesity prevention can be partially due to healthier gut microbiome structure being induced by certain components contained in breast milk, for example, oligosaccharides [64].

Human milk oligosaccharides (HMOs) hold the third rank place among various components in breast milk as per prevalence after lactose and lipids; they play a key role in creating and maintaining healthy gut microbiota of an infant via supporting growth of such benign bacteria genera as Bifidobacterium, Lactobacillus and Akkermansia [29, 65]. HMOs profile is unique in each woman and it provides each infant with a unique gut microbiota [65]. Researchers point out that A. muciniphila and $B$. longum $b v$. Infantis are able to decompose HMOs into simple sugars releasing SCFA in the process that make for maintaining proper functioning of the gut barrier and pro- 
vide a host's body with energy; it makes the most significant contribution into supporting healthy metabolic state.

However, SCFA do not only act as energetic substrates for their host but also as signal molecules that influence energy consumption and metabolism. SCFA are ligands for at least two receptors, free fatty acid receptors 2 and 3 (FFAR2 and FFAR3) [6]. These receptors are expressed by gut epithelium cells and APUDsystem cells. An increase in SCFA contents in the guts is thought to be related to a proportionate increase in pancreatic polypeptide, glucagon-like peptide, and leptin that suppress appetite; hence, FFAR2 and FFAR3 modulate host's energy balance via effects related to gut microbiota [6]. These examples allow us to conclude that SCFA are able to tune metabolism in a host's body via regulating energy metabolism, appetite, and fat accumulation.

Therefore, breast milk is optimal and best-balanced nutrition for an infant that can provide proper development. It has been proven that lactation period being longer than 6 months produces beneficial effects on gut microbiota formation in a child $[66,67]$. Given all the above-mentioned facts, we can state that feeding provided for infants makes a substantial contribution into their growth and development. A period starting from conception and up to a child reaching 4 years of age is considered to be the most significant for induction of such pathophysiological disorders that ultimately result in child obesity and in future in adult one.

Ways to treat obesity in childhood. Nowadays, a conventional way to treat obesity is to combine physical activity, proper diet, and medications as well as bariatric surgery. In developed countries specific eating habits are widely spread and very popular; these eating habits involve elevated consumption of saturated fats, animal proteins, refined carbohydrates and low consumption of fiber [68]. Some researchers state that such dietary patterns result in overall decrease in quantity of gut microbiota bacteria and serious deviations in a ratio between prevailing bacteria phyla Bacteriodetes and Firmicutes [69, 70]. De Fillippo et al. compared microbiota samples taken from children who lived in rural areas in Burkina-Faso and children from urban areas in Italy [71]. African children consumed mostly fiber and vegetable polysaccharides but Italian children predominantly ate animal proteins, carbohydrates, and fats. As a result, the authors established an authentic discrepancy between 4 genera in gut microbiota, where Actinobacteria and Bacteriodetes prevailed in children from Burkina-Faso and Firmicutes and Proteobacteria were prevailing bacteria in Italian children. There is data on an association between balanced nutrition with high fiber consumption and greater bacteria variety [71, 72]. Keeping to the Mediterranean diet also produces positive effects on gut microbiota [73]. People who follow this diet usually have decreased Firmicutes contents and an increase in overall SCFA contents [74].

Surgery is the most radical way to fight obesity [75]. Bariatric surgery started to appear as an independent surgical sub-specialty in 1950-s and has been constantly developed ever since [76]. These surgeries basically aim to efficiently reduce weight, to cause as few postoperative complications as it is only possible and to improve patients' life quality. Sleeve gastrectomy and gastric bypass hold the leading places among all possible surgical operations performed all over the world [75]. Apart from direct beneficial effects produced on weight reduction, bariatric surgeries also have positive influence on metabolism and comorbidity. Experts revealed a correlation between gastric bypass and a decrease in dextrose contents as well as glycated hemoglobin in patients suffering from type II diabetes mellitus. There are also data on changes in gut microbiota with growing Bacteriodetes and A. Muciniphila prevalence in such patients [77]. However, it still seems rather a controversial issue whether such a radical approach as surgical operation is to be applied when it comes to treating obesity in children. 
Global obesity pandemic is spreading too rapidly and it requires new treatment procedures. Weight loss associated with various impacts exerted on gut microbiota is a promising trend in this research. Thus, Hibberd et al. established that intake of a Bifidobacteriumlactisbased probiotic was associated with control over body weight in patients with obesity [78]. Microbiota samples were examined profoundly and the examination revealed an increase in contents of lactobacilli and akkermansia indicating that a balance in microbiota typical for healthy people was reached. When Bifidobacteriumlactis were taken together with polydextrose, it resulted in growing quantities of bacteria belonging to Akkermansia and Christensenellaceae (Firmicutes) genera and Methanobrevibacter genus Archae and there was also a reduction in Paraprevotella (Bacteriodetes) quantity [78]. L. Payahoo et al. examined potential ole- oylethanolamide (OEA, natural fatty acids amide) intake as a medication for weight loss. It was established that oleoylethanolamide intake by patients who suffered from obesity resulted in growing $A$. muciniphila contents in gut microbiota structure [79].

However, despite there are multiple data on beneficial effects produced by probiotics and prebiotics on gut microbiota, experts have not yet reached a common opinion on their efficiency. When such treatment is prescribed, it can cause certain risks that are not examined enough; there will also be no personalized treatment approach, and research is likely to yield controversial results.

Funding. The research was not granted any sponsor support.

Conflict of interests. The authors declare there is no any conflict of interests.

\section{References}

1. Garabedian L.F., Ross-Degnan D., Wharam J.F. Mobile Phone and Smartphone Technologies for Diabetes Care and Self-Management. Current Diabetes Reports, 2015, vol. 15, no. 12, pp. 109. DOI: $10.1007 / \mathrm{s} 11892-015-0680-8$

2. Davis C.D. The gut microbiome and its role in obesity. Nutr. Today, 2016, vol. 51, no. 4, pp. 167-174. DOI: 10.1097/NT.0000000000000167

3. Davis H.C. Can the gastrointestinal microbiota be modulated by dietary fibre to treat obesity? Irish Journal of Medical Science, 2018, vol. 187, no. 2, pp. 393-402. DOI: 10.1007/s11845-017-1686-9

4. Obesity and overweight. World health organization. Available at: https://www.who.int/newsroom/fact-sheets/detail/obesity-and-overweight (23.09.2020) (in Russian).

5. Pihl A.F., Fonvig C.E., Stjernholm T., Hansen T., Pedersen O., Holm J.-C. The role of the gut microbiota in childhood obesity. Childhood Obesity, 2016, vol. 12, no. 4, pp. 292-299. DOI: 10.1089/chi.2015.0220

6. Gérard P. Gut microbiota and obesity. Cellular and Molecular Life Sciences, 2016, vol. 73, no. 1, pp. 147-162. DOI: 10.1007/s00018-015-2061-5

7. Li D., Wang P., Wang P., Hu X., Chen F. The gut microbiota: A treasure for human health. Biotechnology Advances, 2016, vol. 34, no. 7, pp. 1210-1224. DOI: 10.1016/j.biotechadv.2016.08.003

8. Wang B., Yao M., Lv L., Ling Z., Li L. The Human Microbiota in Health and Disease. Engineering, 2017, vol. 3, no. 1, pp. 71-82. DOI: 10.1016/J.ENG.2017.01.008

9. Styne D.M., Arslanian S.A., Connor E.L., Farooqi I.S., Murad M.H., Silverstein J.H., Yanovski J.A. Pediatric obesity-assessment, treatment, and prevention: An endocrine society clinical practice guideline. J. Clin. Endocrinol. Metab., 2017, vol. 102, no. 3, pp. 709-757. DOI: 10.1210/jc.2016-2573

10. McCuen-Wurst C., Ruggieri M., Allison K.C. Disordered eating and obesity: associations between binge-eating disorder, night-eating syndrome, and weight-related comorbidities. Annals of the New York Academy of Sciences, 2018, vol. 1411, no. 1, pp. 96-105. DOI: 10.1111/nyas.13467 
11. Hewagalamulage S.D., Lee T.K., Clarke I.J., Henry B.A. Stress, cortisol, and obesity: a role for cortisol responsiveness in identifying individuals prone to obesity. Domestic Animal Endocrinology, 2016, vol. 56, pp. S112-S120. DOI: 10.1016/j.domaniend.2016.03.004

12. St-Onge M.P. Sleep-obesity relation: underlying mechanisms and consequences for treatment. Obesity Reviews, 2017, vol. 18, no. 1, pp. 34-39. DOI: 10.1111/obr.12499

13. Ogilvie R.P., Patel S.R. The epidemiology of sleep and obesity. Sleep Health, 2017, vol. 3, no. 5, pp. 383-388. DOI: 10.1016/j.sleh.2017.07.013

14. Locke A.E., Kahali B., Berndt S.I., Justice A.E., Pers T.H., Day F.R., Powell C., Vedantam S. [et al.]. Genetic studies of body mass index yield new insights for obesity biology. Nature, 2015, vol. 518 , no. 7538 , pp. 197-206. DOI: 10.1038/nature 14177

15. Amiri P., Jalali-Farahani S., Rezaei M., Hosseinpanah F., Aziz F. Which obesity phenotypes predict poor health-related quality of life in adult men and women? Tehran Lipid and glucose study. PLOS ONE, vol. 13, no. 9, pp. e0203028. DOI: 10.1371/journal.pone.0203028

16. Andrea S.B., Hooker E.R., Messer L.C., Tandy T., Boone-Heinonen J. Does the association between early life growth and later obesity differ by race/ethnicity or socioeconomic status? A systematic review. Annals of Epidemiology, 2017, vol. 27, no. 9, pp. 583-592.e5. DOI: 10.1016/j.annepidem.2017.08.019

17. White P., Skirrow H., George A., Memon A. A systematic review of economic evaluations of local authority commissioned preventative public health interventions in overweight and obesity, physical inactivity, alcohol and illicit drugs use and smoking cessation in the United Kingdom. J. Public Health (Oxf), 2018, vol. 40, no. 4, pp. e521-e530. DOI: 10.1093/pubmed/fdy026

18. Anhê F.F., Varin T.V., Schertzer J.D., Marette A. The Gut Microbiota as a Mediator of Metabolic Benefits after Bariatric Surgery. Canadian Journal of Diabetes, 2017, vol. 41, no. 4, pp. 439-447. DOI: 10.1016/j.jcjd.2017.02.002

19. Fontané L., Boix D.B., Arno A.G., Sanz G.L., Montoya J.P.-B. Influencia de la microbiota y de los probióticos en la obesidad. Clínica e Investig.en Arterioscler, 2018, vol. 30, no. 6, pp. 271-279.

20. Gérard P. Gut microbiota and obesity. Cellular and Molecular Life Sciences, 2016, vol. 73, no. 1, pp. 147-162. DOI: 10.1007/s00018-015-2061-5

21. Indiani C.M.D.S.P., Rizzardi K.F., Castelo P.M., Fábio L. Ferraz C., Darrieux M., Manzano Parisotto T. Childhood Obesity and Firmicutes/Bacteroidetes Ratio in the Gut Microbiota: A Systematic Review. Childhood Obesity, 2018, vol. 14, no. 8, pp. 501-509. DOI: 10.1089/chi.2018.0040

22. Crovesy L., Masterson D., Rosado E.L. Profile of the gut microbiota of adults with obesity: a systematic review. Eur. J. Clin. Nutr, 2020, vol. 74, no. 9, pp. 1251-1262. DOI: 10.1038/s41430-020-0607-6

23. Shin N.R., Whon T.W., Bae J.W. Proteobacteria: Microbial signature of dysbiosis in gut microbiota. Trends in Biotechnology, 2015, vol. 33, no. 9, pp. 496-503. DOI: 10.1016/j.tibtech.2015.06.011

24. Duncan S.H., Hold G.L., Harmsen H.J.M., Stewart C.S., Flint H.J. Growth requirements and fermentation products of Fusobacterium prausnitzii, and a proposal to reclassify it as Faecalibacterium prausnitzii gen. nov., comb. nov. Int. J. Syst. Evol. Microbiol, 2002, vol. 52, no. 6, pp. 2141-2146. DOI: $10.1099 / 00207713-52-6-2141$

25. Lopez-Siles M., Duncan S.H., Garcia-Gil L.J., Martinez-Medina M. Faecalibacterium prausnitzii: From microbiology to diagnostics and prognostics. ISME Journal, 2017, vol. 11, no. 4, pp. 841-852. DOI: $10.1038 /$ ismej.2016.176

26. Martín R., Miquel S., Benevides L., Bridonneau C., Robert V., Hudault S., Chain F., Berteau O. [et al.]. Functional characterization of novel Faecalibacterium prausnitzii strains isolated from healthy volunteers: A step forward in the use of F. prausnitzii as a next-generation probiotic. Front. Microbiol, 2017, vol. 8, no. 30, pp. 1226. DOI: 10.3389/fmicb.2017.01226

27. Million M., Angelakis E., Maraninchi M., Henry M., Giorgi R., Valero R., Vialettes B., Raoult D. Correlation between body mass index and gut concentrations of Lactobacillus reuteri, Bifidobacterium animalis, Methanobrevibacter smithii and Escherichia coli. Int. J. Obes. Int J Obes (Lond), 2013, vol. 37, no. 11, pp. 1460-1466. DOI: 10.1038/ijo.2013.20 
28. Drissi F., Merhej V., Angelakis E., El Kaoutari A., Carrière F., Henrissat B., Raoult D. Comparative genomics analysis of Lactobacillus species associated with weight gain or weight protection. Nutr. Diabetes, 2014, vol. 4, no. 2, pp. e109. DOI: 10.1038/nutd.2014.6

29. Geerlings S.Y., Kostopoulos I., de Vos W.M., Belzer C. Akkermansia muciniphila in the Human Gastrointestinal Tract: When, Where, and How? Microorganisms, 2018, vol. 6, no. 3, pp. 75. DOI: 10.3390/microorganisms6030075

30. Derrien M., Belzer C., de Vos W.M. Akkermansia muciniphila and its role in regulating host functions. Microbial Pathogenesis, 2017, vol. 106, pp. 171-181. DOI: 10.1016/j.micpath.2016.02.005

31. Engels C., Ruscheweyh H.-J., Beerenwinkel N., Lacroix C., Schwab C. The common gut microbe Eubacterium hallii also contributes to intestinal propionate formation. Front. Microbiol, 2016, vol. 19, no. 7, pp. 713. DOI: 10.3389/fmicb.2016.00713

32. Ghavami S.B.,Rostami E., Sephay A.A., Shahrokh S., Balaii H., Aghdaei H.A., Zali M.R. Alterations of the human gut Methanobrevibacter smithii as a biomarker for inflammatory bowel diseases. Microb. Pathog, 2018, no. 117, pp. 285-289. DOI: 10.1016/j.micpath.2018.01.029

33. Perez-Muñoz M.E., Arrieta M.-C., Ramer-Tait A.E., Walter J. A critical assessment of the «sterile womb» and «in utero colonization» hypotheses: Implications for research on the pioneer infant microbiome. Microbiome, 2017, vol. 28, no. 5 (1), pp. 48. DOI: 10.1186/s40168-017-0268-4

34. Gschwind R., Fournier T., Butel M.-J., Wydau-Dematteis S. Microbiota establishment: An in utero colonization decisive for future health? Medecine Sciences, 2018, vol. 34, no. 4, pp. 331-337. DOI: $10.1051 /$ medsci/20183404014

35. Riva A., Borgo F., Lassandro C., Verduci E., Morace G., Borghi E., Berry D. Pediatric obesity is associated with an altered gut microbiota and discordant shifts in Firmicutes populations. Environ. Microbiol, 2017, vol. 19, no. 1, pp. 95-105. DOI: 10.1111/1462-2920.13463

36. Borgo F., Verduci E., Riva A., Lassandro C., Riva E., Morace G., Borghi E. [et al.]. Relative Abundance in Bacterial and Fungal Gut Microbes in Obese Children: A Case Control Study. Child. Obes., 2017, vol. 13, no. 1, pp. 78-84. DOI: 10.1089/chi.2015.0194

37. Bergström A., Skov T.H., Bahl M.I., Roager H.M., Christensen L.B., Ejlerskov K.T., Mølgaard C., Michaelsen K.F., Licht T.R. Establishment of intestinal microbiota during early life: A longitudinal, explorative study of a large cohort of Danish infants. Appl. Environ. Microbiol., 2014, vol. 80, no. 9, pp. 2889-2900. DOI: 10.1128/AEM.00342-14

38. Scheepers L.E.J.M., Penders J., Mbakwa C.A., Thijs C., Mommers M., Arts I.C.W. The intestinal microbiota composition and weight development in children: The KOALA Birth Cohort Study. Int. J. Obes., 2015, vol. 39, no. 1, pp. 16-25. DOI: 10.1038/ijo.2014.178

39. Xu P., Li M., Zhang J., Zhang T. Correlation of intestinal microbiota with overweight and obesity in Kazakh school children. BMC Microbiol., 2012, vol. 12, pp. 283. DOI: 10.1186/14712180-12-283

40. Vael C., Verhulst S.L., Nelen V., Goossens H., Desager K.N. Intestinal microflora and body mass index during the first three years of life: An observational study. Gut Pathog., 2011, vol. 3, no. 1, pp. 8. DOI: $10.1186 / 1757-4749-3-8$

41. Ignacio A., Fernandes M.R., Rodrigues V.A.A., Groppo F.C., Cardoso A.L., AvilaCampos M.J., Nakano V. Correlation between body mass index and faecal microbiota from children. Clin. Microbiol. Infect., 2016, vol. 22, no. 3, pp. 258.e1-258.e8. DOI: 10.1016/j.cmi.2015.10.031

42. Milani C., Duranti S., Bottacini F., Casey E., Turroni F., Mahony J., Belzer C., Delgado Palacio S. [et al.]. The First Microbial Colonizers of the Human Gut: Composition, Activities, and Health Implications of the Infant Gut Microbiota. Microbiol. Mol. Biol. Rev, 2017, vol. 8, no. 81 (4), pp. e00036-e000317. DOI: 10.1128/MMBR.00036-17

43. Butler É.M., Chiavaroli V., Derraik J.G.B., Grigg C.P., Wilson B.C., Walker N., O'Sullivan J.M., Cutfield W.S. Maternal bacteria to correct abnormal gut microbiota in babies born by C-section. Medicine (Baltimore), 2020, vol. 99, no. 30, pp. e21315. DOI: 10.1097/MD.0000000000021315

44. Li H.T., Zhou Y.B., Liu J.M. The impact of cesarean section on offspring overweight and obesity: A systematic review and meta-analysis. International Journal of Obesity, 2013, vol. 37, no. 7, pp. 893-899. DOI: 10.1038/ijo.2012.195 
45. Darmasseelane K., Hyde M.J., Santhakumaran S., Gale C., Modi N. Mode of delivery and offspring body mass index, overweight and obesity in adult life: A systematic review and metaanalysis. PLoS One, 2014, vol. 26, no. 9 (2), pp. e87896. DOI: 10.1371/journal.pone.0087896

46. Kuhle S., Tong O.S., Woolcott C.G. Association between caesarean section and childhood obesity: A systematic review and meta-analysis. Obesity Reviews, 2015, vol. 16, no. 4, pp. 295-303. DOI: $10.1111 /$ obr.12267

47. Rutayisire E., Huang K., Liu Y., Tao F. The mode of delivery affects the diversity and colonization pattern of the gut microbiota during the first year of infants' life: A systematic review. BMC Gastroenterol., 2016, vol. 16, no. 1, pp. 86. DOI: 10.1186/s12876-016-0498-0

48. Ortega-Garciá J.A., Kloosterman N., Alvarez L., Tobarra-Sánchez E., Cárceles-Álvarez A., Pastor-Valero R., López-Hernández F.A., Sánchez-Solis M., Claudio L. Full Breastfeeding and Obesity in Children: A Prospective Study from Birth to 6 Years. Child. Obes., 2018, vol. 14, no. 5, pp. 327-337. DOI: $10.1089 /$ chi.2017.0335

49. Dominguez-Bello M.G., De Jesus-Laboy K.M., Shen N., Cox L.M., Amir A., Gonzalez A., Bokulich N.A., Song S.J. [et al.]. Partial restoration of the microbiota of cesarean-born infants via vaginal microbial transfer. Nat. Med. Nature Publishing Group, 2016, vol. 22, no. 3, pp. 250-253. DOI: $10.1038 / \mathrm{nm} .4039$

50. Wallby T., Lagerberg D., Magnusson M. Relationship between Breastfeeding and Early Childhood Obesity: Results of a Prospective Longitudinal Study from Birth to 4 Years. Breastfeed. Med., 2017, vol. 12, no. 1, pp. 48-53. DOI: 10.1089/bfm.2016.0124

51. Singhal A., Kennedy K., Lanigan J., Fewtrell M., Cole T.J., Stephenson T., Elias-Jones A., Weaver L.T. [et al.]. Nutrition in infancy and long-term risk of obesity: Evidence from 2 randomized controlled trials. Am. J. Clin. Nutr., 2010, vol. 92, no. 5, pp. 1133-1144.DOI: 10.3945/ajen.2010.29302

52. Koletzko B., von Kries R., Closa R., Escribano J., Scaglioni S., Giovannini M., Beyer J., Demmelmair H. [et al.]. Can infant feeding choices modulate later obesity risk? Am. J. Clin. Nutr., 2009, vol. 89, no. 5, pp. 1502S-1508S. DOI: 10.3945/ajcn.2009.27113D

53. Michaelsen K.F., Greer F.R. Protein needs early in life and long-term health. Am. J. Clin. Nutr., 2014, vol. 99, no. 3, pp. 718S-722S. DOI: 10.3945/ajen.113.072603

54. Larnkjœr A., Mølgaard C., Michaelsen K.F. Early nutrition impact on the insulin-like growth factor axis and later health consequences. Current Opinion in Clinical Nutrition and Metabolic Care, 2012, vol. 15, no. 3, pp. 285-292. DOI: 10.1097/MCO.0b013e328351c472

55. Sahin S., Ozdemir T., Katipoglu N., Akcan A.B., Kaynak M. Turkmen et al. Comparison of Changes in Breast Milk Macronutrient Content during the First Month in Preterm and Term Infants. Breastfeed. Med., 2020, vol. 15, no. 1, pp. 56-62. DOI: 10.1089/bfm.2019.0141

56. Wang M., Radlowski E.C., Li M., Monaco M.H., Donovan S.M. Feeding Mode, but Not Prebiotics, Affects Colonic Microbiota Composition and Volatile Fatty Acid Concentrations in SowReared, Formula-Fed, and Combination-Fed Piglets. J. Nutr., 2019, vol. 149, no. 12, pp. 2156-2163. DOI: $10.1093 / \mathrm{jn} / \mathrm{nxz} 183$

57. Kirchberg F.F., Hellmuth C., Totzauer M., Uhl O., Closa-Monasterolo R., Escribano J., Gruszfeld D., Gradowska K. [et al.]. Impact of infant protein supply and other early life factors on plasma metabolome at 5.5 and 8 years of age: a randomized trial. Int. J. Obes., 2020, vol. 44, no. 1, pp. 69-81. DOI: 10.1038/s41366-019-0398-9

58. Fleddermann M., Demmelmair H., Grote V., Bidlingmaier M., Grimminger P., Bielohuby M., Koletzko B. Role of selected amino acids on plasma IGF-I concentration in infants. Eur. J. Nutr., 2017, vol. 56, no. 2, pp. 613-620.DOI: 10.1007/s00394-015-1105-9

59. Brands B., Demmelmair H., Koletzko B. How growth due to infant nutrition influences obesity and later disease risk. Acta Paediatrica, 2014, vol. 103, no. 6, pp. 578-585. DOI: 10.1111/apa.12593

60. Fleddermann M., Demmelmair H., Grote V., Nikolic T., Trisic B., Koletzko B. Infant formula composition affects energetic efficiency for growth: The BeMIM study, a randomized controlled trial. Clin. Nutr., 2014, vol. 33, no. 4, pp. 588-595. DOI: 10.1016/j.clnu.2013.12.007 
61. Devan S.R.K., Arumugam S., Shankar G., Poosala S. Differential sensitivity of chronic high-fat-diet-induced obesity in Sprague-Dawley rats. J. Basic Clin. Physiol. Pharmacol, 2018, vol. 29, no. 5, pp. 553-563. DOI: 10.1515/jbcpp-2017-0030

62. Das U.N. The lipids that matter from infant nutrition to insulin resistance. Prostaglandins Leukotrienes and Essential Fatty Acids, 2002, vol. 67, no. 1, pp. 1-12. DOI: 10.1054/plef.2002.0374

63. Verduci E., Banderali G., Barberi S., Radaelli G., Lops A., Betti F., Riva E., Giovannini M. Epigenetic effects of human breast milk. Nutrients, 2014, vol. 6, no. 4, pp. 1711-1724. DOI: 10.3390/nu6041711

64. Vuillermin P.J., Macia L., Nanan R., Tang M.L.K., Collier F., Brix S. The maternal microbiome during pregnancy and allergic disease in the offspring. Seminars in Immunopathology, 2017, vol. 39, no. 6, pp. 669-675. DOI: 10.1007/s00281-017-0652-y

65. Bering S.B. Human milk oligosaccharides to prevent gut dysfunction and necrotizing enterocolitis in preterm neonates. Nutrients, 2018, vol. 10, no. 10, pp. 1461. DOI: 10.3390/nu10101461

66. Ortega-Garciá J.A., Kloosterman N., Alvarez L., Tobarra-Sánchez E., Cárceles-Álvarez A., Pastor-Valero R., López-Hernández F.A., Sánchez-Solis M., Claudio L. Full Breastfeeding and Obesity in Children: A Prospective Study from Birth to 6 Years. Child. Obes., 2018, vol. 14, no. 5, pp. 327-337. DOI: 10.1089/chi.2017.0335

67. Marseglia L., Manti S., D'Angelo G., Cuppari C., Salpietro V., Filippelli M., Trovato A., Gitto E., Salpietro C., Arrigo T. Obesity and breastfeeding: The strength of association. Women and Birth, 2015, vol. 28, no. 2, pp. 81-86. DOI: 10.1016/j.wombi.2014.12.007

68. Zinöcker M.K., Lindseth I.A. The western diet-microbiome-host interaction and its role in metabolic disease. Nutrients, 2018, vol. 10, no. 3, pp. 365. DOI: 10.3390/nu10030365

69. Singh R.K., Chang H.-W., Yan D., Lee K.M., Ucmak D., Wong K., Abrouk M., Farahnik B. [et al.]. Influence of diet on the gut microbiome and implications for human health. Journal of Translational Medicine, 2017, vol. 8, no. 15 (1), pp. 73. DOI: 10.1186/s12967-017-1175-y

70. Hills R.D., Pontefract B.A., Mishcon H.R., Black C.A., Sutton S.C., Theberge C.R. Gut microbiome: Profound implications for diet and disease. Nutrients, 2019, vol. 11, no. 7, pp. 1613. DOI: $10.3390 /$ nu11071613

71. De Filippo C., Cavalieri D., Di Paola M., Ramazzotti M., Baptiste PoulletJ., Massart S., Collini S., Pieraccini G., Lionetti P. Impact of diet in shaping gut microbiota revealed by a comparative study in children from Europe and rural Africa. Proc. Natl. Acad. Sci. U. S. A., 2010, vol. 107, no. 33, pp. 14691-14696. DOI: 10.1073/pnas.1005963107

72. Holscher H.D. Dietary fiber and prebiotics and the gastrointestinal microbiota. Gut Microbes, 2017, vol. 8, no. 2, pp. 172-184. DOI: 10.1080/19490976.2017.1290756

73. Gentile C.L., Weir T.L. The gut microbiota at the intersection of diet and human health. Science, 2018, vol. 362, no. 6416, pp. 776-780. DOI: 10.1126/science.aau5812

74. Garcia-Mantrana I., Selma-Royo M., Alcantara C., Collado M.C. Shifts on gut microbiota associated to mediterranean diet adherence and specific dietary intakes on general adult population. Front. Microbiol., 2018, vol. 7, no. 9, pp. 890. DOI: 10.3389/fmicb.2018.00890

75. Colquitt J.L., Pickett K., Loveman E., Frampton G.K. Surgery for weight loss in adults. Cochrane Database of Systematic Reviews, 2014, vol. 2014, no. 8, pp. CD003641. DOI: 10.1002/14651858.CD003641.pub4

76. Phillips B.T., Shikora S.A. The history of metabolic and bariatric surgery: Development of standards for patient safety and efficacy. Metabolism: Clinical and Experimental, 2018, no. 79, pp. 97-107. DOI: 10.1016/j.metabol.2017.12.010

77. Cortez R.V., Petry T., Caravatto P., Pessôa R., Sanabani S.S., Martinez M.B., Sarian T., Salles J.E., Cohen R., Taddei C.R. Shifts in intestinal microbiota after duodenal exclusion favor glycemic control and weight loss: a randomized controlled trial. Surg. Obes. Relat. Dis., 2018, vol. 14, no. 11 ,pp. 1748-1754.DOI: 10.1016/j.soard.2018.07.021

78. Hibberd A.A., Yde C.C., Ziegler M.L., Honoré A.H., Saarinen M.T., Lahtinen S., Stahl B., Jensen H.M., Stenman L.K. Probiotic or synbiotic alters the gut microbiota and metabolism in a ran- 
domised controlled trial of weight management in overweight adults. Benef. Microbes, 2019, vol. 10, no. 2, pp. 121-135. DOI: 10.3920/BM2018.0028

79. Payahoo L., Khajebishak Y., Alivand M.R., Soleimanzade H., Alipour S., Barzegari A., Ostadrahimi A. Investigation the effect of oleoylethanolamide supplementation on the abundance of Akkermansia muciniphila bacterium and the dietary intakes in people with obesity: A randomized clinical trial. Appetite, 2019, vol. 1, no. 141, pp. 104301. DOI: 10.1016/j.appet.2019.05.032

Petrova P.Yu., Aga A.D., Trapeznikova E.S., Budanova E.V. Gut microbiota as risk factor causing obesity in children. Health Risk Analysis, 2021, no. 1, pp. 159-172. DOI: 10.21668/health.risk/2021.1.17.eng

Received: 26.01.2021

Accepted: 16.02 .2021

Published: 30.03.2021 
UDC 614.39

DOI: $10.21668 /$ health.risk/2021.1.18.eng

Review

\title{
REGULATION OF WORK-RELATED AND OCCUPATIONAL IMPACTS ON WORKERS EMPLOYED AT RAILROADS: EXPERIENCE GAINED IN RUSSIA AND OTHER COUNTRIES
}

\author{
V.A. Loginova ${ }^{1}$, Yu.N. Kas'kov ${ }^{1}$, E.A. Zhidkova ${ }^{2,3}$, K.G. Gurevich ${ }^{3}$, \\ Yu.L. Smertina ${ }^{4}$, O.A. Pletnikova ${ }^{4}$ \\ ${ }^{1}$ Federal Service for Surveillance over Consumer Rights Protection and Human Wellbeing, Railway transport \\ office, 17 Dubininskaya Str., Moscow, 115054, Russian Federation \\ ${ }^{2}$ The Central Healthcare Office, a brunch of «Russian Railways» JSC, 52a Malaya Gruzinskaya Str., Moscow, \\ 123557, Russian Federation \\ ${ }^{3}$ A.I. Yevdokimov Moscow State University of Medicine and Dentistry, 20/1 Delegatskaya Str., Moscow, 127473, \\ Russian Federation \\ ${ }^{4}$ Center for Hygiene and Epidemiology at railway transport, 2 the $1^{\text {st }}$ Basmanniy lane, Moscow, 105066, \\ Russian Federation
}

The present research is vital as it will allow increasing safety of working conditions for workers employed at railway transport due to reducing impacts exerted by occupational risk factors.

Our research goal was to perform comparative analysis of requirements to labor protection provided for railway workers.

Our research was performed via non-systemic analysis of literature that involved searching through Elibrary, Pubmed and Cochrane databases as per certain key words.

As a result, we showed that railway traffic involved exposure to numerous occupational risk factors; due to it, a significant number of workplaces, including those of enginemen and other railway workers, belonged to the $3^{\text {rd }}$ (adverse) hazard category. Basic occupational risk factors included noise and vibration; psychoemotional loads borne by engine team workers and traffic controllers; exposure to industrial aerosols; electromagnetic irradiation; fluctuations in microclimatic parameters in engines' cabs. All these occupational factors influence not only workers who are directly employed at railways but also people who live in close proximity to them. Therefore, in most countries there is legislative basis on health protection for people who may be exposed to occupational factors related to railway traffic. Our analysis revealed that in general the existing legislation in Russia corresponded to foreign one. Bases for harmonization of the domestic legislation with foreign one are fixed by the Federal Law issued on December 27, 2002 No. 184-FZ "On technical regulation”.

Harmonization of domestic and foreign legislation on reducing total exposure to occupational risk factors allows preserving long-term working ability and preventing work-related diseases.

Key words: occupational risk factors, railway transport, preventive medicine, engine team, health protection, noise, vibration, microclimate, electromagnetic irradiation.

Modern economy can't develop without railways since they are among the largest passenger and cargo transporters. Railways have made a substantial contribution into prospering

economy in many countries and are among the most beneficial means of transport that can be used regardless of a season and weather conditions. Low transportation costs are their great-

(c) Loginova V.A., Kas'kov Yu.N., Zhidkova E.A., Gurevich K.G., Smertina Yu.L., Pletnikova O.A., 2021

Vera A. Loginova - Deputy supervisor (e-mail: va-loginova@mail.ru; tel.: +7 (495) 633-27-19; ORCID: https://orcid.org/00000001-8852-2898).

Yurii N. Kas'kov - Supervisor (e-mail: kaskov.mps@bk.ru; tel.: +7 (499) 235-25-72; ORCID: https://orcid.org/00000001-2345-6789).

Elena A. Zhidkova - Supervisor, lecturer (e-mail: genmedc@gmail.com; tel.: +7 (499) 262-56-34; ORCID: https://orcid.org/00000002-6831-9486).

Konstantin G. Gurevich - Doctor of Medical Sciences, Professor, Head of the Department (e-mail: kgurevich@mail.ru; tel.: +7 (495) 681-88-31; ORCID: https://orcid.org/0000-0002-7603-6064).

Yuliya L. Smertina - Chief physician (e-mail: zamfbuz@mail.ru; tel.: +7 (495) 607-44-63; ORCID: https://orcid.org/00000003-4142-4232).

Oksana A. Pletnikova - Deputy to the Head of the Department for Operational Organization and Statistic Provision (e-mail: zamfbuz@mail.ru; tel.: +7 (495) 607-44-63; ORCID: https://orcid.org/0000-0003-4471-6070). 
est advantage since they are approximately 3 times lower than motor transport ones. Railway transport is a relatively energy-efficient mean of transportation [1].

At the same time, railway traffic involves several occupational risk factors; due to them significant number of workplaces including those of engine team workers and other railway-related occupations belong to the third hazard category, class 3.1 and 3.2 [2]. Most common adverse factors are noise, vibration, psychoemotional loads borne by engine team workers and traffic controllers, exposure to occupational aerosols, predominantly chemical ones, electromagnetic radiation, changing microclimatic parameters in engine cabins, etc. ${ }^{1}[3]$.

All the above-mentioned occupational factors exert their influence not only on people who directly work at railways but also on people who live in close proximity to them. Therefore, there are health protection programs in most countries in the world that are to protect health of people who can in this or that way be exposed to railways-related occupational factors. Such programs are aimed at reducing occupationally induced damage to health of workers and/or people who live in close proximity to railways. However, given common goals, there are discrepancies in approaches accepted in different countries regarding both control over exposure to railwayrelated occupational factors and prevention of their negative effects.

Our research goal was to perform comparative examination of world experience in regulating occupationally-induced effects produced by railways on a human body. Publications on the chosen subject are reviewed sequentially for different occupational risk factors.

Data and methods. We performed nonsystemic analysis of literature using Elibrary, Pubmed and Cochrane databases via searching keywords either in Russian or English. Search depth was not preset; our chosen keywords were railways and railway transport, as well as occupational risk factors (noise, vibration, electromagnetic radiation, and microclimate). Morphologic changes in a word base or use of a synonym were allowed. We included only full-text articles into our review. In case authors published several similar works, we took only the latest one.

Results and discussion. Noise. "Acoustics-Estimation of noise-induced hearing loss» ${ }^{2}$, ISO 1999:2013 standard, is a basic international document that determines recommended noise exposure for workers; it was last reviewed in 2018 and therefore is still valid. It was issued to replace ISO 1999:1990 «Acoustics-Determination of occupational noise exposure and estimation of noise-induced hearing impairment» ${ }^{3}$. A similar standard that is valid in the RF is GOST R ISO 1999-2017 "Acoustic. Assessing hearing loss due to exposure to noise ${ }^{4}$. The standard contains data on statistic correlations between exposure to noise and «a constant shift in hearing threshold caused by noise». The standard also includes procedures for assessing hearing loss for different categories of people taking their age into account including occupational noiseinduced hearing loss. In literature certain issues are discussed that focus on a possibility to apply the standard for making objective assessment of exposure to noise existing in an engine cabin [4].

\footnotetext{
${ }^{1}$ On the sanitary-epidemiologic situation in railway transport in 2018: The state report. Moscow, Rospotrebnadzor's Railway Transport Office, 2019, 56 p. (in Russian).

${ }^{2}$ ISO 1999:2013 «Acoustics - Estimation of noise-induced hearing loss». ISO: International Organization for Standardization. Available at: https://www.iso.org/home.html (09.08.2020) (in Russian).

${ }^{3}$ ISO 1999:1990 «Acoustics - Determination of occupational noise exposure and estimation of noise-induced hearing impairment». ISO: International Organization for Standardization. Available at: https://www.iso.org/standard/6759.html (09.08.2020) (in Russian).

${ }^{4}$ GOST R ISO 1999-2017. Acoustic. Assessing hearing loss due to exposure to noise. KODEKS: an electronic fund for legal and reference documentation. Available at: http://docs.cntd.ru/document/1200157242 (09.08.2020) (in Russian).
} 
Here we should note that occupational noise-induced hearing loss is detected in approximately $37 \%$ of adult employable population all over the world. $97 \%$ of people who suffer from this disorder are males. As a rule, the disease develops without any symptoms or with very few ones. Despite there are research works on the matter, occupational associations in foreign countries, as a rule, pay very little attention to protecting workers' acoustic organs [5]. For example, in the USA up to $10 \%$ age-related hearing problems are considered to be caused by exposure to noise [6]. Sensorineural hearing loss is thought to be the most widely spread occupationallyinduced disease among railway transport workers, first of all, enginemen and their assistants [7-9]. It has been proven that excessive exposure to noise does not only result in hearing loss in future but also leads to mistakes during work being much more probable. And such mistakes can even result in preemergency or emergency [10].

Basically noise caused by trains and their movement is related to overall feeling of unease, discomfort, and irritation that are detected both in railway workers and people living in close proximity to it [11]. Apart from hearing disorders, exposure to noise increases risks of cardiovascular diseases, neurological diseases, and gastric diseases [12, 13]. A person who is exposed to loud noise can't concentrate properly, gets tired rapidly, and consumes more calories with food [14, 15].

We should note that most research works that were accomplished in western countries and focused on impacts exerted by noise on health dealt with this problem among musicians, builders, and agricultural workers [16]. In the RF, workers employed by «Russian Railways» PLC account for approximately $1 \%$ of the total employed population; builders, $7.3 \%$; agricultural workers, $5.8 \%$ (as per data taken from rzd.ru and gsk.ru web-sites on August 09, 2020).

In the RF, Rospotrebnadzor is a competent organization responsible for assessing exposure to occupational risk factors [17]. The existing regulatory documents fix maximum permissible noise level (MPL) at $80 \mathrm{dBA}$.

Meanwhile, exposure to noise in an engine cabin can reach $92 \mathrm{~dB}$ even in developed countries and it is louder than a gunshot $(87-89 \mathrm{~dB})$. The authors of the cited study recommend using protective equipment for enginemen's acoustic organs [18]. Over recent years, there is a trend in developed countries for resolving noise-related issues via engine park modernization. New engines are constructed with up-to-date suspension, sound insulation systems, etc. In the Western Europe special attention is paid to assessing technical condition of any vehicle, including noise it makes [19]. Therefore, attention is paid to examining noise generation, noise sources detection, noise suppression and insulation, etc. [20]. A study performed in Norway in 2013 initially didn't reveal more frequent hearing loss in modern engine drivers in comparison with people from other occupational groups [21]. However, later the authors showed that there was significant hearing loss among engine team workers older than 45 in comparison with people from other occupational groups; this loss was detected for $3-5 \mathrm{kHz}$ frequencies and $3-5 \mathrm{~dB}$ intensity [22].

In a research work accomplished in the USA, it was detected that noise level in an engine cabin depended on a year an engine was put into operation, its technical condition, as well as an engine type (electric, diesel, etc.) [23]. In Canada noise levels in engine cabins were measured for different railway routes. It was shown that in summer average noise level $(88 \mathrm{~dB})$ was higher than in winter $(84 \mathrm{~dB})$. Noise level was higher than $85 \mathrm{~dB}$ in $59 \%$ of all examined cabins and it was even higher than $90 \mathrm{~dB}$ in $13 \%$ [24]. We should note that recently impacts on engine team workers' health under discussion have not been only those exerted by highly intense sounds but also infrasound and the role the latter plays in health disorders is extremely difficult to examine [25]. Besides, railway landscapes also exert their 
influence on occurrence of diseases that are caused by railways noise. Thus, tunnels make hearing loss occurrence more probable. Another issue being discussed at the moment is probable impacts exerted on enginemen's health by noise shields [26].

We should note that engine park is also being modernized in the RF at the moment. A number of engine cabins with conditions inside them being unfavorable as per noise is decreasing but still engine park modernization is far from being completed ${ }^{5}$. Besides, «Russian Railways» PLC also uses retro-trains and their engines can't be modernized.

Foreign authors tend to consider exposure to noise as a basic factor causing diseases not only among railway workers but also people who live or work in close proximity to railways [27-31]. For example in Norway hearing loss was detected among people who directly maintained railway beds [32]. A retrospect study on railway workers' audiograms performed in the USA and Europe revealed that $63 \%$ workers were regularly exposed to noise equal to $75-90 \mathrm{~dB}$. $31 \%$ people who are exposed to such noise levels suffer from hearing loss in future within $4 \mathrm{kHz}$ range, and men tend to have such disorders more frequently than women [33].

In our opinion, regulation over effects produced by noise on railway workers requires further development. First of all, it is necessary to take into account duration of exposure during working hours and rest. Besides, at present impacts exerted by noise are being examined in standardized conditions. Meanwhile, railway bed condition, tunnels, and constructions located in close proximity to railways as well as some other factors can change parame- ters of exposure to noise. Therefore, it is necessary to develop procedures for assessing exposure to noise during switching and line movement.

Vibration. On international level, impacts exerted by vibration on a human body are determined in accordance with ISO 2631-1: $1997^{6}$, the similar document that is valid in the RF is GOST 31191.1-2004 (ISO 2631-1: 1997) «Vibration and shock. Measuring overall vibration and assessing its effects on a human body» ${ }^{7}$. However, contemporary research works reveal that this standard does not fully take into account overall impacts exerted by vibration on a human body especially when this vibration is related to spatial moving [34].

Standardized vibration MPL is $112(\mathrm{Zo})$ 115 (XoYo) dB. Up to $12 \%$ of engine cabins in the RF do not correspond to hygienic standards as per vibration; and here vibration exceeds MPL by 2 times in $87 \%$ cases and by 2-3 times in 30\% cases [35]. Given excessive noise and vibration, working conditions at most enginemen's workplaces belong to 3.1 and 3.2 hazard categories [36]. Meanwhile, there are practically no studies accomplished in developed countries that would focus on examining vibration levels in an engine cabin. Exposure to vibration for an engineman is believed to be reduced via a specifically designed seat with proper ergonomics and vibration-absorbing elements [37]. However, a small comparative study didn't reveal any significant influence exerted by technical modernization on how workers subjectively perceived effects produced by vibration on their bodies [38]. At the same time it was shown that non-optimal ergonomics at a workplace did not only caused higher risks that the vibra-

\footnotetext{
${ }^{5}$ Yu.V. Pronnikov. Updating vibroacoustic calculation procedures and engine cabins design: Abstract of the thesis ... for the Candidate of Technical Sciences degree. Rostov-na-Donu, 2012, 18 p. (in Russian).

${ }^{6}$ ISO 2631-1:1997. Mechanical vibration and shock - Evaluation of human exposure to whole-body vibration Part 1: General requirements. ISO: International Organization for Standardization. Available at: https://www. iso.org/ru/standard/7612.html (09.08.2020) (in Russian).

${ }^{7}$ GOST 31191.1-2004 (ISO 2631-1:1997). Vibration and shock. Measuring overall vibration and assessing its effects on a human body. KODEKS: an electronic fund for legal and reference documentation. Available at: http://docs.cntd.ru/document/1200060904 (09.08.2020) (in Russian).
} 
tion disease might occur but also resulted in greater number of complaints from enginemen about pains in the neck, lumbar spine, etc. [39]. Excessive vibration can also lead to overall health deterioration [40].

However, vibration level in an engine cabin depends not only on its design but also railway bed condition and engine speed (measurements taken in the same engine cabin under different movement modes can yield different results). It was proven that when speed exceeded $70 \mathrm{~km} /$ hour, most technical devices that should absorb vibration do not accomplish their task completely [41]. Besides, vibration in an engine cabin can also depend on a train length, its overall mass, and some other external factors $[42,43]$. Exposure to vibration also changes depending on a posture an engineman has to maintain (sitting or standing) [44].

There are also data on long-term exposure to vibration, even within MPL limits, can result in occupationally-induced vitamin D and testosterone deficiency in enginemen $[45,46]$. Such hormonal disorders may be an additional risk factor that causes occurrence or more rapid development of cardiovascular diseases among engine team workers [47]. Recently it has been reported that vibration produces certain effects on the cardiac muscle contractibility regardless of other risk factors being present or absent. These effects can be mediated via the autonomous nervous system [47]. When vibration in an engine cabin was modeled in laboratory conditions, it was accompanied with the sympathetic nervous system activation that resulted in drowsiness [48].

Elevated risks of pains in the lumbar spine, neck, and knee were detected for work- ers who maintained railway beds; these risks were related to vibration caused by moving trains [49]. Another issue under discussion is a possibility that vibration might influence passengers' health [50].

Besides, vibration that occurs due to train movement can influence proper operation of seismological stations or stability of capital constructions located in close proximity to railways [51, 52].

We should note that regulation over impacts exerted by vibration on an engineman both in Russia and abroad involves using standardized conditions. As it is clear from the data given above, actual conditions in which engines are used can yield different results. Besides, duration of exposure to vibration has great significance even if this vibration is within MPL limits. This fact should also be taken into account in future studies and in developing new standards.

Electromagnetic exposure. Standards for safe electromagnetic exposure for a human body differ greatly in different countries. In the RF electromagnetic radiation produced by railways is regulated by requirements fixed in the SER 2.2.4.3359-16 «Sanitary-epidemiologic requirements to physical factors at workplaces» ${ }^{8}$, SER 2.2.4.1191-03 «Electromagnetic fields at workplaces»" ${ }^{9}$, SNR 2971-84 «Sanitary norms and rules for protecting population from exposure to electromagnetic fields created by air transmission lines that transmit alternating current with industrial frequency» ${ }^{10}$ and GOST 12.1.045-84 «Electrostatic fields. Permissible levels at workplaces and requirements to control activities» ${ }^{11}$. Besides, it is necessary

\footnotetext{
${ }^{8}$ SER 2.2.4.3359-16. Sanitary-epidemiologic requirements to physical factors at workplaces. KODEKS: an electronic fund for legal and reference documentation. Available at: http://docs.cntd.ru/document/420362948 (09.08. 2020) (in Russian).

${ }^{9}$ SER 2.2.4.1191-03. Sanitary-epidemiologic requirements to physical factors at workplaces. KODEKS: an electronic fund for legal and reference documentation. Available at: http://docs.cntd.ru/document/901853847 (09.08.2020) (in Russian).

${ }^{10}$ SNR 2971-84. Sanitary norms and rules for protecting population from exposure to electromagnetic fields created by air transmission lines that transmit alternating current with industrial frequency. KODEKS: an electronic fund for legal and reference documentation. Available at: http://docs.cntd.ru/document/5200214 (09.08.2020) (in Russian).

${ }^{11}$ GOST 12.1.045-84. Electrostatic fields. Permissible levels at workplaces and requirements to control activities. KODEKS: an electronic fund for legal and reference documentation. Available at: http://docs.cntd.ru/document/9051575 (09.08.2020) (in Russian).
} 
to remember that current used for railways electrification has different properties in different countries. Thus, in the RF railways are electrified with direct current equal to 3,000 $\mathrm{W}$ and alternating current equal to $25 \mathrm{~kW} 50$ $\mathrm{Hz}$ and $25 \mathrm{~kW} \cdot 250 \mathrm{~Hz}$; in Europe, direct current equal to $1,500 \mathrm{~W}$ and alternating current equal to $15 \mathrm{~kW} 16^{2} / 3 \mathrm{~Hz}$; in the USA, alternating current equal to $11 \mathrm{~kW} 25 \mathrm{~Hz}$. Current may also have different properties depending on landscape peculiarities (for example, in pits). There is also specific electricity supply inside depots. All this makes it more difficult to perform comparative studies on impacts exerted by electromagnetic radiation on enginemen's bodies. Besides, we should bear in mind that exposure to electromagnetic radiation depends on an engine type.

In the RF electromagnetic field intensity, both as per its electric and magnetic component, was lower than MPL at all examined enginemen's workplaces. However, older engines (produced prior to 2008) tend to create electromagnetic fields with higher intensity than modern ones. We should note that greater electromagnetic field intensity is usually detected at electrified parts of railways [53]. Engine park modernization that is now being performed in the RF will allow decreasing electromagnetic field intensity in an engine cabin [54]. Similar technical solutions are also implemented abroad [55]. However, existing MPL for electromagnetic radiation do not take its cumulative effects into account. Therefore, there is still an open issue related to long-term exposure to electromagnetic field and its effects on health even if parameters of this field are within permissible levels [56].

We managed to find only one work where the authors stated that electromagnetic exposure caused elevated risks of heart rate disorders and sudden cardiac death [57].
However, this study was not a multi-centered one, and therefore, its results seem rather doubtful. Besides, according to our own data, an engine type (electric or diesel) does not influence risks of sudden cardiac death for enginemen or their assistants [58]. There are also works that focus on negative effects produced by alternating current on enginemen's immune system [59].

Another issue under discussion is influence exerted by electromagnetic fields on train passengers, railway bed repairmen, and people living in close proximity to railways [60, 61]. There was a 31-year study performed in Sweden; it revealed that electromagnetic exposure caused by railways might have cumulative effects thus resulting in higher risks of Alzheimer disease, myeloid leucosis, and Hodgkin lymphoma both among enginemen and railway beds repairmen [62, 63]. It was revealed that railway electrification system might influence operation of electric appliances located close to railways, in particular, electrocardiographs [64].

In our opinion, issues related to electromagnetic exposure being safe for enginemen's bodies have not been studied enough. It is unclear to what extent foreign experience in electromagnetic exposure regulation can be used in the RF due to currents with different properties used to electrify railways in our country and abroad. An open issue is also cumulative effects produced by electromagnetic exposure. Probably, standards for total exposure will have to be developed in future.

Microclimate in a cabin. Chemical factors. On international level microclimate inside an engine cabin is regulated by ISO 19659-1: $2017^{12}$ and ISO 19659-2: 2020 «Heating, ventilation and air conditioning systems for rolling stock» ${ }^{13}$. These regulatory

${ }^{12}$ ISO 19659-1:2017. Railway applications - Heating, ventilation and air conditioning systems for rolling stock - Part 1: Terms and definitions. ISO: International Organization for Standardization. Available at: https://www.iso.org/standard/65762.html (09.08.2020) (in Russian).

${ }^{13}$ ISO 19659-2:2020. Railway applications - Heating, ventilation and air conditioning systems for rolling stock - Part 2: Thermal comfort. ISO: International Organization for Standardization. Available at: https://www.iso.org/ru/standard/70232.html (09.08.2020) (in Russian). 
documents are partially reflected in GOST 33463.1-2015 «Life-support systems on railway rolling stock» ${ }^{14}$. Modern engine cabins are specifically designed to achieve maximum protection from exposure to temperature factor [65]. Studies that were performed in the $\mathrm{RF}$ and focused on microclimate inside engine cabins didn't reveal any deviations from existing standards. But still, most questioned engine team workers complain about uncomfortable temperature conditions inside an engine cabin [66]. We believe that most such complaints are rather subjective; still, we have to remember that exposure to too high or too low air temperature may result in lower working capacity, greater probability of an error, deterioration of engine team workers' health that will involve subsequent medical rehabilitation [67].

Visual loads caused by sleeper and infrastructure objects flickering, light from signal posts, lamps, etc., changes between night and daytime during a trip, moving through tunnels, are a microclimatic factor that is difficult to assess. For example, it was proven that bright sunlight or moving into and out of a tunnel created additional visual loads [68]. It was detected that visual organs of engine team workers were prone to elevated functional fatigue regardless of movement type, switching or main-line one [69]. Therefore, it is recommended to use prophylaxis aimed at preventing visual organs diseases in people who directly deal with train movement [70].

Modern engines are equipped with air cleaning systems; therefore, according to laboratory studies performed over 2012-2016, there was a decrease in air samples taken at enginemen's workplaces that deviated from hygienic standards as per chemicals MPC. However, air inside cabins still can't be completely purified from all the substances that come from outside. The most significant contaminants include nitrogen oxides, sulfur compounds, carbon oxides, hydrocarbons, as well as soot [71, 72]. Air contamination becomes especially acute issue in closed spaces, for example, tunnels [73]. However, total measurements of major contaminants revealed that effects produced by them on passengers, railway workers, and enginemen were negligible. It is due to small concentrations of pollutants, even inside tunnels [74].

We should note that domestic regulatory documents fix standards for microclimate inside engine cabins to a greater extent than for microclimate inside passenger carriages, as opposed to foreign regulation. We didn't manage to find any studies focusing on influence exerted by microclimate on health of passenger carriage workers. Probably, future works in the sphere will allow developing new approaches to microclimate standardization.

Conclusion. The Federal Law issued on December 27, 2002 No. 184-FZ «On technical regulation» ${ }^{15}$ made substantial alterations into legislative documents that regulated sanitaryepidemiologic aspects of railway traffic safety [75]. Most Russian regulatory documents are now in conformity with international practices. Overall, we should mention that Russian authors tend to pay much more attention to examining occupational risk factors and effects they produce on a human body whereas their foreign counterparts try to find solutions to health-related issues via various technical innovations.

There are still certain unresolved issues that require further investigation for regulation system development:

1. Most occupational risk factors are measured in standardized conditions. It is necessary to develop procedures for their measuring taking into account everyday peculiarities related to rolling stock operation.

\footnotetext{
${ }^{14}$ GOST 33463.1-2015. Life support systems on railway rolling stock. KODEKS: an electronic fund for legal and reference documentation. Available at: http://docs.cntd.ru/document/1200133110 (09.08.2020) (in Russian).

${ }^{15}$ On technical regulation: The Federal Law issued on December 27, 2002 No, 184-FZ. KODEKS: an electronic fund for legal and reference documentation. Available at: http://docs.cntd.ru/document/901836556 (09.08.2020) (in Russian).
} 
2. Exposure to occupational risk factors is limited with absolute values and probable accumulation of total exposure to an occupational factor is neglected. In case there is total exposure to a factor, time periods between shifts. That is, time when exposure is absent, are not taken into account or standardized.

3. Probable impacts on health exerted by under-threshold values of occupational risk factors are also neglected. Such effects are most likely to be related to total exposure accumulation.

4. It is necessary to further standardize exposure to occupational risk factors; first of all, in case there are no such procedures for them (visual loads, for example).

We hope that further development of legislative base for regulation over exposure to occupational risk factors and their effects on railway workers will allow improving their health and extending their active working life due to occupationally-induced diseases being successfully prevented.

Funding. The research was not granted any sponsor support.

Conflict of interests. The authors declare there is no any conflict of interests.

\section{References}

1. Plakhotnik V.N., Lakhnova J.V. Interaction of railway objects with the environment. Environmental Economics, 2002, no. 4, pp. 163-169.

2. Klochkova E.A. Okhrana truda na zheleznodorozhnom transporte [Labor protection provided for railway workers]. Moscow, Marshrut Publ., 2004, 412 p. (in Russian).

3. Samarskaya N.A. Analysis of the working conditions peculiarities and development of measures to ensure the metro workers safety. Ekonomika truda, 2019, vol. 6, no. 3, pp. 1271-1284 (in Russian).

4. Titova T.S., Kopytenkova O.I., Kurepin D.E. Acoustic impact assessment. Zheleznodorozhnyi transport, 2017, no. 5, pp. 75-77 (in Russian).

5. Kurmis A.P., Apps S.A. Occupationally-acquired noise-induced hearing loss: a senseless workplace hazard. Int J. Occup. Med. Environ. Health, 2007, vol. 20, no. 2, pp. 127-136. DOI: 10.2478/v10001-007-0016-2

6. Dobie R.A. The burdens of age-related and occupational noise-induced hearing loss in the United States. Ear. Hear., 2008, vol. 29, no. 4, pp. 565-577. DOI: 10.1097/AUD.0b013e31817349ec

7. Marushkina G.I., Mironova E.A., Plokhov V.N. Otsenka klinicheskoi i farmakoekonomicheskoi effektivnosti preparatov neiromediatornykh aminokislot $\mathrm{i}$ ingibitorov kholinesterazy $\mathrm{v}$ lechenii khronicheskoi sensonevral'noi tugoukhosti u rabotnikov zheleznodorozhnogo transporta [Assessing clinical and pharmaceutical-economic efficiency of neuromediator amino acids mediactions and choline esterase inhibitors in treating chronic sensorineural hearing loss among railway workers. Vestnik otorinolaringologii: materialy XI Rossiiskogo kongressa otorinolaringologov, 2012, no. 5, pp. 100-102 (in Russian).

8. Pankova V.B., Kaptsov V.A., Kas'kov Yu.N. Hygienic substantiation of risk of development of professional relative deafness at workers locomotive brigades. Byulleten' VSNTs SO RAMN, 2006, no. 3, pp. 38-41 (in Russian).

9. Vil'k M.F., Pankova V.B., Kaptsov V.A. Traffic noise as a risk factor for occupational deafness (exemplified by air and railway transport). Meditsina truda i promyshlennaya ekologiya, 2017, no. 9, pp. 36-37 (in Russian).

10. Girard S.A., Picard M., Davis A.C., Simard M., Larocque R., Leroux T., Turcotte F. Multiple work-related accidents: tracing the role of hearing status and noise exposure. Occup. Environ. Med., 2009, vol. 66, no. 5, pp. 319-324. DOI: 10.1136/oem.2007.037713

11. Nunes P.A.L.D., Travisi C.M. Rail noise-abatement programmes: a stated choice experiment to evaluate the impacts on welfare. Transport Reviews: A Transnational Transdisciplinary Journal, 2007, vol. 27, no. 5, pp. 589-604. DOI: 10.1080/01441640701322693

12. Arezes P.A., Miguel A.S. Hearing protection use in industry: the role of risk perception. Safety Science, 2005, vol. 43, no. 4, pp. 253-267. DOI: 10.1093/annhyg/mef067 
Regulation of work-related and occupational impacts on workers employed at railroads: experience gained ...

13. Virokannas H., Anttonen H., Niskanen J. Health risk assessment of noise, hand-arm vibration and cold in railway track maintenance. International Journal of Industrial Ergonomics, 1994, vol. 13, no. 3, pp. 247-252. DOI: 10.1016/0169-8141(94)90071-X

14. Ustinaviciene R., Piesine L. Morbidity of textile industry workers in Kaunas. Medicina, 2007, vol. 43, no. 6, pp. 495-500.

15. Ustinaviciene R., Obelenis V., Ereminas D. Occupational health problems in modern work environment. Medicina, 2004, vol. 40, no. 9, pp. 897-904.

16. Sliwinska-Kowalska M., Davis A. Noise-induced hearing loss. Noise Health, 2012, vol. 14, no. 61, pp. 274-280. DOI: 10.4103/1463-1741.104893

17. Kas'kov Yu.N. Deyatel'nost' upravleniya Rospotrebnadzora po zheleznodorozhnomu transportu [Activities performed by Rospotrebnadzor Railway Transport Office]. Zheleznodorozhnyi transport, 2019, no. 4, pp. 43-47 (in Russian).

18. Kryter K.D. Hearing loss from gun and railroad noise-relations with ISO standard. J. Acoust. Soc. Am., 1991, vol. 6, no. 90, pp. 3180-3195. DOI: 10.1121/1.401427.1999

19. Joynt J., Kang J. The influence of preconceptions on perceived sound reduction by environmental noise barriers. Science of the Total Environment, 2010, vol. 408, no. 20, pp. 4368-4375. DOI: 10.1016/j.scitotenv.2010.04.020

20. Nekrasiene R., Kucinskiene J. Formation of green areas of the Klaipedda city. Urban green formation. Science Jobs, 2011, vol. 1, no. 8, pp. 147-154 (in Russian).

21. Lie A., Skogstad M., Johnsen T.S., Engdahl B., Tambs K. Hearing status among Norwegian train drivers and train conductors. Occup. Med. (Lond), 2013, vol. 63, no. 8, pp. 544-548. DOI: 10.1093/occmed/kqt114

22. Lie A., Skogstad M., Johnsen T.S., Engdahl B., Tambs K. A cross-sectional study of hearing thresholds among 4627 Norwegian train and track maintenance workers. BMJ Open, 2014, vol. 16, no. 4 (10), pp. e005529. DOI: 10.1136/bmjopen-2014-005529

23. Rotter T. The noise factor in railway locomotives. Applied Ergonomics, 1982, vol. 13, no. 3, pp. 213-215. DOI: 10.1016/0003-6870(82)90014-x

24. Seshagiri B. Exposure to noise on board locomotives. AIHA J. (Fairfax, Va), 2003, vol. 5, no. 64, pp. 699-707. DOI: 10.1202/532.1.1

25. Igolkin A.A., Kryuchkov A.N., Lazutkin G.V., Afanasev K.M. The Study on Vibroacoustic Characteristics of Shunting Locomotive Cabin. Procedia Engineering, 2017, no. 176, pp. 724-731. DOI: $10.1016 /$ j.proeng.2017.02.320

26. Peng Y., Fan C., Hu L., Peng S., Xie P., Wu F., Yi S. Tunnel driving occupational environment and hearing loss in train drivers in China. Occup. Environ. Med., 2019, vol. 2, no. 76, pp. 97-104. DOI: 10.1136/oemed-2018-105269

27. Hahad O., Beutel M., Gori T., Schulz A., Blettner M., Pfeiffer N., Rostock T. [et al.]. Annoyance to different noise sources is associated with atrial fibrillation in the Gutenberg Health Study. Int. J. Cardiol., 2018, vol. 1, no. 264, pp. 79-84. DOI: 10.1016/j.ijcard.2018.03.126

28. Jarosińska D., Héroux M.È., Wilkhu P., Creswick J., Verbeek J., Wothge J., Paunović E. Development of the WHO Environmental Noise Guidelines for the European Region: An Introduction. Int. J. Environ. Res. Public. Health., 2018, vol. 20, no. 15 (4), pp. E813. DOI: 10.3390/ijerph15040813

29. Clark C., Paunovic K. WHO Environmental Noise Guidelines for the European Region: A Systematic Review on Environmental Noise and Cognition. Int. J. Environ. Res. Public. Health., 2018, vol. 7, no. 15 (2), pp. E285. DOI: 10.3390/ijerph15020285

30. Guski R., Schreckenberg D., Schuemer R. WHO Environmental Noise Guidelines for the European Region: A Systematic Review on Environmental Noise and Annoyance. Int. J. Environ. Res. Public. Health., 2017, vol. 8, no. 14 (12), pp. E1539. DOI: 10.3390/ijerph14121539

31. Grubliauskas R., Strukcinskiene B., Raistenskis J., Strukcinskaite V., Buckus R., Janusevicius T. Effects of urban rail noise level in a residential area. Journal of Vibroengineering, 2014, vol. 16, no. 2, pp. 987-996.

32. Lie A., Skogstad M., Johnsen T.S., Engdahl B., Tambs K. Noise-induced hearing loss in a longitudinal study of Norwegian railway workers. BMJ Open, 2016, vol. 2, no. 6 (9), pp. e011923. DOI: 10.1136/bmjopen-2016-011923 
33. Lie A., Skogstad M., Johnsen T.S., Engdahl B., Tambs K. The prevalence of notched audiograms in a cross-sectional study of 12,055 railway workers. Ear. Hear., 2015, vol. 36, no. 3, pp. e86-e92. DOI: 10.1097/AUD.0000000000000129

34. Riesco E., Munoz-Guijosa J.M. An enhanced whole-body vibration emission index for railway vehicles. Ergonomics, 2020, no. 11, pp. 1-11. DOI: 10.1080/00140139.2020.1776899

35. Samarskaya N.A., Il'in S.M. Ensuring safe working conditions and health protection of railway workers. Ekonomika truda, 2018, vol. 5, no. 4, pp. 1329-1345 (in Russian).

36. Ishchenko V.I. Uluchshenie uslovii i okhrany truda na zheleznodorozhnom transporte [Improvement of labor protection for workers employed at railways. Put' i putevoe khozyaistvo, 2005, no. 5, pp. 31-34 (in Russian).

37. Steina G.J., Múčkaa P., Gunstonb T.P., Badurac S. Modelling and simulation of locomotive driver's seat vertical suspension vibration isolation system. International Journal of Industrial Ergonomics, 2008, vol. 38, no. 5-6, pp. 384-395. DOI: 10.1016/j.ergon.2007.08.007

38. Tiemessen I.J.H., Hulshof C.T.J., Frings-Dresen M.H.W. Effectiveness of an occupational health intervention program to reduce whole body vibration exposure: an evaluation study with a controlled pretest-post-test design. Am. J. Ind. Med., 2009, vol. 52, no. 12, pp. 943-952. DOI: $10.1002 /$ ajim.20769

39. Johanning E., Landsbergis P., Fischer S., Christ E., Göres B., Luhrman R. Whole-body vibration and ergonomic study of US railroad locomotives. Journal of Sound and Vibration, 2006, vol. 298, no. 3, pp. 594-600. DOI: 10.1016/j.jsv.2006.06.030

40. Cooperridera N.K., Gordonb J.J. Shock and impact levels on North American locomotives. Journal of Sound and Vibration, 2008, vol. 318, no. 4-5, pp. 809-819. DOI: 10.1016/j.jsv.2008.04.042

41. Kolesnikov I.V., Pronnikov Yu.V. Experimental research of noise and vibration in cabins of locomotives. Vestnik Rostovskogo gosudarstvennogo universiteta putei soobshcheniya, 2011, vol. 43, no. 3, pp. 153-156 (in Russian).

42. Ohara H., Nakagiri S., Itani T., Wake K., Aoyama H. Occupational health hazards resulting from elevated work rate situations. J. Hum. Ergol. (Tokyo), 1976, vol. 5, no. 2, pp. 173-182.

43. Orlova N.V., Starokozheva A.Ya. Risk factors for cardiovascular disease among railway locomotive drivers. Meditsinskii alfavit, 2020, no. 2, pp. 37-40 (in Russian). DOI: 10.33667/20785631-2020-2-37-40

44. Birlik G. Occupational exposure to whole body vibration-train drivers. Ind. Health., 2009, vol. 47, no. 1, pp. 5-10. DOI: 10.2486/indhealth.47.5

45. Orlova N.V., Podzolkov V.I., Starokozheva A.Ya., Doldo N.M., Mironova E.V. Vitamin D deficiency study in railway drivers. Klinicheskaya laboratornaya diagnostika, 2020, vol. 65, no. 3, pp. 163-168 (in Russian).

46. Finagina E.A., Teodorovich O.V., Tsfasman A.Z., Shatokhin M.N., Shekhovtsov S.Yu. Testosterone level dependence on professional factors (on the example of locomotive drivers). Vestnik novykh meditsinskikh tekhnologii, 2017, vol. 24, no. 3, pp. 151-155 (in Russian).

47. Jalilian H., Zamanian Z., Gorjizadeh O., Riaei Z., Monazzam M.R., Abdoli-Eramaki M. Autonomic Nervous System Responses to Whole-Body. Int. J. Occup. Environ. Med., 2019, vol. 10, no. 4, pp. 174-184. DOI: 10.15171/ijoem.2019.1688

48. Zhang N., Fard M., Bhuiyan M.H.U., Verhagen D., Azari M.F., Robinson S.R. The effects of physical vibration on heart rate variability as a measure of drowsiness. Ergonomics, 2018, vol. 61, no. 9, pp. 1259-1272. DOI: 10.1080/00140139.2018.1482373

49. Landsbergis P., Johanning E., Stillo M., Jain R., Davis M. Occupational risk factors for musculoskeletal disorders among railroad maintenance-of-way workers. Am. J. Ind. Med., 2020, vol. 63, no. 5, pp. 402-416. DOI: 10.1002/ajim.23099

50. Sharp C., Woodcock J., Sica G., Peris E., Moorhouse A.T., Waddington D.C. Exposureresponse relationships for annoyance due to freight and passenger railway vibration exposure in residential environments. J. Acoust. Soc. Am., 2014, vol. 135, no. 1, pp. 205-212. DOI: 10.1121/1.4836115

51. Murakami Y., Yano T., Morinaga M., Yokoshima S. Effects of Railway Elevation, Operation of a New Station, and Earthquakes on Railway Noise Annoyance in Kumamoto, Japan. Int. J. Environ. Res. Public. Health., 2018, vol. 5, no. 15 (7), pp. 1417. DOI: 10.3390/ijerph15071417 
Regulation of work-related and occupational impacts on workers employed at railroads: experience gained ...

52. Gidlöf-Gunnarsson A., Ögren M., Jerson T., Öhrström E. Railway noise annoyance and the importance of number of trains, ground vibration, and building situational factors. Noise Health, 2012, vol. 4, no. 59, pp. 190-201. DOI: 10.4103/1463-1741.99895

53. Zal'tsman M.D., Tsygankov S.G., Tovasarov A.D., Konyrbaev R.T., Akberliev A.B. Analiz rezul'tatov attestatsii rabochikh mest AO «LOKOMOTIV» po usloviyam truda [Analysis of results obtained via assessing workplaces at «Lokomotiv» JSC as per working conditions]. Vestnik Kazakhskoi akademii transporta i kommunikatsii im. M. Tynyshpaeva, 2015, vol. 92, no. 1, pp. 10-17 (in Russian).

54. Kabantsev A.A. Nekotorye izmeneniya v konstruktsii elektrovozov 2ES5K «ERMAK» [Certain changes in construction of 2EC5K «ERMAK» electric locomotives]. Lokomotiv, 2017, vol. 721, no. 1, pp. 30-31 (in Russian).

55. Aerts S., Verloock L., Martens L., Joseph W. Compliance boundaries for train protection systems. Radiat Prot. Dosimetry., 2014, vol. 158, no. 1, pp. 68-72. DOI: 10.1093/rpd/nct183

56. Klimchenko L.N., Cherkasova T.S., Chubar' E.P. Prognozirovanie neblagopriyatnogo elektromagnitnogo vliyaniya na ob"ektakh zheleznodorozhnogo transporta [Predicting adverse electromagnetic impacts at railway transport objects]. Vestnik Rostovskogo gosudarstvennogo universiteta putei soobshcheniya, 2001, vol. 5, no. 1, pp. 126-129 (in Russian).

57. Santangelo L., Di Grazia M., Liotti F., De Maria E., Calabró R., Sannolo N. Magnetic field exposure and arrhythmic risk: evaluation in railway drivers. Int Arch Occup Environ Health, 2005, vol. 78, no. 4, pp. 337-341. DOI: 10.1007/s00420-004-0541-2

58. Zhidkova E.A., Naigovzina N.B., Kalinin M.R., Gutor E.M., Gurevich K.G. The Analysis of the Causes of Sudden Deaths among Workers of Locomotive Crews. Kardiologiya, 2019, no. 6, pp. 42-47 (in Russian).

59. Liu Y.M., Sun H.L., Luo Y., Dong Z.L., Ye W.S.Z. Influence of electric traction extremely low frequency electromagnetic field on immune function of train drivers. Bing. Za. Zhi., 2008, vol. 26, no. 11, pp. 659-660.

60. Aerts S., Plets D., Thielens A., Martens L., Joseph W. Impact of a small cell on the RF-EMF exposure in a train. Int. J. Environ. Res. Public. Health., 2015, vol. 27, no. 12 (3), pp. 2639-2652. DOI: $10.3390 /$ ijerph120302639

61. Niu D., Zhu F., Qiu R., Niu Q. Exposure to electromagnetic fields aboard high-speed electric multiple unit trains. J. Biol. Regul. Homeost. Agents, 2016, vol. 30, no. 3, pp. 727-731.

62. Röösli M., Lörtscher M., Egger M., Pfluger D., Schreier N., Lörtscher E., Locher P., Spoerri A., Minder C. Mortality from neurodegenerative disease and exposure to extremely lowfrequency magnetic fields: 31 years of observations on Swiss railway employees. Neuroepidemiology, 2007, vol. 28, no. 4, pp. 197-206. DOI: 10.1159/000108111

63. Röösli M., Lörtscher M., Egger M., Pfluger D., Schreier N., Lörtscher E., Locher P., Spoerri A., Minder C. Leukaemia, brain tumours and exposure to extremely low frequency magnetic fields: cohort study of Swiss railway employees. Occup. Environ. Med., 2007, vol. 64, no. 8, pp. 553-559. DOI: 10.1136/oem.2006.030270

64. Schlimp C.J., Breiteneder M., Seifert J., Lederer W. Interference of 16.7-Hz electromagnetic fields on measured electrocardiogram. Bioelectromagnetics, 2007, vol. 28, no. 5, pp. 402-405. DOI: $10.1002 /$ bem.20319

65. Khudonogov A.M., Volosatov S.N. K kontseptsii proektirovaniya system mikroklimata v kabine upravleniya lokomotivom [On a concept for designing microclimate systems in a locomotive cab]. Transportnaya infrastruktura Sibirskogo regiona, 2013, no. 2, pp. 352-357 (in Russian).

66. Serikov V.V., Zhidkova E.A., Kolyagin V.Ya., Zakrevskaya A.A., Bogdanova V.E. Social and psychologic, organizational factors influencing occupational activity of locomotive crew workers. Meditsina truda i promyshlennaya ekologiya, 2017, no. 7, pp. 17-21 (in Russian).

67. Dubilei G.S., Zaikina N.V. Professional'naya reabilitatsiya rabotnikov lokomotivnykh brigad [Occupational rehabilitation for engine team workers]. Cardio Somatika, 2013, no. S1, pp. 29 (in Russian). 
68. Byankina I.N., Panova I.E., Leonova E.S., Pavlenko O.A. Modern trends of ophthalmologic morbidity and visual health state in railway workers responsible for train control system. Permskii meditsinskii zhurnal, 2009, vol. 26, no. 6, pp. 127-131 (in Russian).

69. Leonova E.S., Byankina I.N., Shchekotov E.V., Karaulovskaya E.A. Results of deep clinical and physiologic study of eye in locomotive operators. Meditsina truda i promyshlennaya ekologiya, 2011, no. 1, pp. 38-42 (in Russian).

70. Leonova E.S. Mediko-sotsial'naya i ekonomicheskaya effektivnost' profilaktiki narushenii zreniya u mashinistov lokomotivov [Medical-social and economic efficiency of eye sight disorders prevention for enginemen]. Sbornik nauchnykh tezisov i statei «Zdorov'e i obrazovanie v XXI veke», 2011, vol. 13, no. 3, pp. 318-319 (in Russian).

71. Farkhatdinov G.A., Kas'kov Yu.N., Podkorytov Yu.I., Svitenko O.A. Aktual'nye voprosy obespecheniya sanitarno-epidemiologicheskoi bezopasnosti passazhirskikh i gruzovykh perevozok zheleznodorozhnym transportom Rossii [The actual problems of supply of sanitarium and epidemiological safety of passenger and goods trans-portation by Russian railways]. Dezinfektsiya. Antiseptika, 2014, vol. 5, no. 2, pp. 28-32 (in Russian).

72. Kas'kov Yu.N., Podkorytov Yu.I. The actual problems of supply of sanitarium and epidemiological safety of passenger and goods transportation by Russian railways. Meditsina truda i ekologiya cheloveka, 2016, no. 4, pp. 91-97 (in Russian).

73. Cha Y., Tu M., Elmgren M., Silvergren S., Olofsson U. Factors affecting the exposure of passengers, service staff and train drivers inside trains to airborne particles. Environ. Res., 2018, no. 166, pp. 16-24. DOI: 10.1016/j.envres.2018.05.026

74. Seaton A., Cherrie J., Dennekamp M., Donaldson K., Hurley J.F., Tran C.L. The London Underground: dust and hazards to health. Occup. Environ. Med., 2005, vol. 62, no. 6, pp. 355-362. DOI: $10.1136 /$ oem.2004.014332

75. Leksin A.G. Sanitary epidemiologic safety and technical regulations on railway transport. Meditsina truda i promyshlennaya ekologiya, 2009, no. 7, pp. 17-21 (in Russian).

Loginova V.A., Kas'kov Yu.N., Zhidkova E.A., Gurevich K.G., Smertina Yu.L., Pletnikova O.A. Regulation of work-related and occupational impacts on workers employed at railroads: experience gained in Russia and other countries. Health Risk Analysis, 2021, no. 1, pp.173-184. DOI: 10.21668/health.risk/2021.1.18.eng

Received: 08.02.2021

Accepted: 02.03.2021

Published: 30.03.2021 
UDC 613.6.027

DOI: $10.21668 /$ health.risk/2021.1.19.eng

Review

\section{ON CERTAIN ISSUES RELATED TO CHRONIC EXPOSURE TO OCCUPATIONAL NOISE AND IMPACTS EXERTED BY IT ON WORKERS' BODIES (LITERATURE REVIEW)}

\section{V.F. Spirin, A.M. Starshov}

Saratov Hygiene Medical Research Center of the Federal Scientific Center for Medical and Preventive Health Risk Management Technologies, 1a Zarechnaya Str., Saratov, 410022, Russian Federation

Chronic exposure to noise becomes especially significant when it occurs at workplaces since it results not only in deteriorated life quality of workers but also in disorders in their occupational activities. Occupational sensorineural hearing loss (SHL) holds the $1^{\text {st }}$ rank place among occupational diseases caused by exposure to industrial physical factors. As any other work-related disease, sensorineural hearing loss makes it more difficult to preserve labor resources in the country and leads to significant economic losses. Given that, it is extremely vital to develop procedures for early diagnostics, to determine all possible risks that cause hearing loss directly or indirectly, and to create efficient prevention activities aimed at preserving health of workers exposed to noise at their workplaces.

We reviewed literature data published over the last 5-7 years and analyzed more than 100 scientific works on the matter. Our review covers data from 61 sources that are the most relevant regarding tasks we aimed to solve in this research.

Literature analysis allowed us to conclude that hearing loss caused by chronic exposure to noise at a workplace was a rather significant problem outlined by occupational medicine experts all over the world. It was shown that noise factor, apart from its direct impacts on the acoustic apparatus, produced apparent negative effects on many organs and systems causing various functional disorders in them which could directly or indirectly exacerbate hearing loss in workers.

Key words: in-plant noise, vibration, sensorineural hearing loss, prevalence, occupational hygiene, risk factors, primary hypertension, life quality, smoking, alimentary factor.

At present there are certain top priority activities that are to be accomplished by the state; when it comes down to labor relations and labor protection, a key issue here is to provide working conditions that allow minimizing risks related to a decrease in population in Russia and providing optimal age structure of the population. Given that, an urgent task that occupational medicine has to solve is accomplishing research works within state programs that are aimed at substantiating hygienic regulations. These regulations should provide safe and comfortable working conditions and reduce risks of occupational and work-related diseases for workers who have to contact adverse occupational factors at their workplaces.
Contemporary challenges make experts in occupational medicine develop new approaches to substantiating regulations that are aimed at reducing or eliminating adverse impacts exerted by occupational environment on workers. It necessarily requires developing a prevention system that secures long-term employable period, better life quality for workers, and greater prestige of occupations that involve exposure to adverse and/or hazardous hygienic factors.

Despite considerable success in the sphere, workers employed in many industrial branches still have to face exposure to hygienic factors at their workplaces; the situation occurs all over the world and such factors often exceed permissible levels greatly ${ }^{1}$. The

(C) Spirin V.F., Starshov A.M., 2021

Vladimir F. Spirin - Doctor of Medical Sciences, Professor, Leading researcher, Head of the Occupational Hygiene Department (e-mail: vlad.spirin2011@yandex.ru; tel.: +7 (8452) 92-30-48; ORCID: https://orcid.org/0000-0002-2987-0099).

Andrey M. Starshov - Researcher (e-mail: labergphys@gmail.com; tel.: +7 (8452) 92-30-48; ORCID: https://orcid.org/ 0000-0002-6499-0459).

${ }^{1}$ The Russian statistical annual data collection. 2017. Rosstat. Moscow, 2017, 686 p. (in Russian). 
problem is still persistent in many industrial brunches in the Russian Federation and it produces a negative effect on workers' employable period [1].

Coal mining, oil processing, metallurgy, agriculture, and aircraft building are among basic industries where workers are exposed to adverse hygienic physical factors. Naturally, occupational and work-related morbidity tends to be high in these branches and it exerts substantial influence on a demographic situation in the country and creates certain economic and social «tensions». X. Li et al. [2] point out there is a great contribution made by noise into SHL development among workers and provide data collected by the WHO proving that almost half a billion people all over the world have various problems with hearing. These hearing disorders cannot be cured and cause economic losses that are equal to approximately 750 billion USD.

World economy at the current stage in its development is aimed at satisfying growing social and communal demands of population; it unavoidably involves developing and applying more and more advanced production technologies and many of them still generate a lot of noise including noise being louder than permissible levels. Thus, even in industrially developed South Korea noise was detected to be louder than $80-90 \mathrm{dBA}$ in $64.6 \%$ cases examined at more than 52 thousand industrial enterprises where production involved noise generation.

Nowadays people have to face rather «noisy» domestic ecosystem. There are data on hearing disorders prevalence in $10.7 \%$ out of 164,770 examined people who were randomly selected for that study; these hearing disorders were not work-related or occupational ones [3].

Population studies taken in dynamics over 25 years indicated that workers suffering from occupational diseases had shorter life expectancy than healthy ones [4]. The authors showed that miners with occupational pathologies died from diseases that had etiological relation with their working conditions in $92.6 \%$ cases. And we should stress that only people with the best functional parameters were employed at that production since it involved exposure to a lot of adverse occupational factors; all workers had profound medical examinations prior to being employed. Obviously, should there be improvements in all the set of social-and hygienic factors including occupational ones, it will have a positive effect on overall workers' life expectancy [5].

But at the same time, there are certain issues at present that do not allow achieving proper quality of medical examinations for workers. When examining working conditions and medical aid provided for workers employed at industrial enterprises and in agriculture many authors mention serious drawbacks in periodical medical examinations (PME) and failure to detect and diagnose occupational diseases (OD) in workers [6-10]. It is often the case that two or three occupational diseases are first diagnosed in a worker during a PME accomplished in an occupational medical center; unfortunately, it usually results in growing disability among such workers $[11,12]$. I.V. Tikhonova also mentions poor quality of medical examinations provided for workers employed at production with loud noise at workplaces [13, 14]. We should also point out that in the RF clinical experts do not always pursue the unified approach to formulating a clinical diagnosis when there is hearing loss caused by exposure to noise. Unfortunately, it can have negative influence on overall assessment of the occupational pathology service in the country as well as on making managerial decisions and developing a proper prevention system. All this will ultimately lead to deteriorating labor potential in leading industrial branches and agriculture and will create negative attitudes among young people towards production with a lot of noise at workplaces.

Substantial experience has been accumulated via scientific research on SHL prevalence among workers exposed to occupational noise [12, 15-17]. We should highlight that 
recently morbidity with occupational SHL has grown by 2-2.5 times [18, 19].

Sensorineural hearing loss takes a leading place among occupational diseases [17-22]. Unfortunately, SHL prevalence is still high among workers exposed to occupational noise [16]. Specific weight of SHL among all OD reaches $73 \%$ in workers employed at railways; more than $20 \%$, in machinery operators in agriculture. Hearing loss often results in certain limitations imposed on occupational activities. Thus, SHL is the reason for flying crew members not being allowed to work in $85 \%$ cases [23]. Despite prevention activities accomplished at all levels, occupational diseases of the hearing organs caused by exposure to occupational noise still prevail and there is no descending trend in this prevalence [9, 24-27].

People who suffer from SHL together with vibration disease tend to have a considerable decrease in adaptation potential of the circulatory system [28]. When workers were exposed to these adverse hygienic factors, experts revealed adaptation failure in $14 \%$ examined workers, and adaptation was unsatisfactory in another $43.33 \%$. I.B. Soldatov mentioned complicated polyetiological processes involved in sensorineural hearing loss development among workers with «noisy» occupations as far back as in $1997^{2}$.

Recently obtained data allow paying greater attention to SHL development from the etiological pint of view under exposure to common noise beyond working environment. In this respect, we should mention an interesting study by K.P. Luzhetskiy et al. [29] who examined people living in a zone exposed to a large aviation site. The research allowed revealing bilateral conductive hearing loss among children aged 4-7 in 5\% cases; $30.3 \%$ examined people had functional disorders in the hearing analyzer with mild mixed hearing loss. Results obtained by other authors in their research works also indicate that exposure to noise may be hazardous for schoolchildren and teenagers since they revealed significant deviations in functional state of the hearing organs [30]. Results obtained in those research works substantiate advisability of noise loads on schoolchildren to be taken into account especially in cases when these school children choose occupations involving exposure to occupational noise since «sound attacks» from earphones combined with external noise lead to damage done to hair cells in the internal ear. Long-term exposure to aggressive and loud music (there are NIOSH standards for that factor) results in hearing loss among young «music lovers». We can assume that SHL will occur sooner in such people under exposure to occupational noise than it is expected according to conventional concepts on a usual period of time required for this pathology to develop. It should be taken into account when prevention activities are developed at production. In this respect, some research works are of interest since their results indicate that hearing loss can probably be caused both by occupational factors and loud music in earphones [31].

There was also a study that revealed a necessity to take military service into account when examining hearing loss. The results revealed more apparent hearing loss among workers who had previously served in the army and used small arms against those who didn't have military service in their life [32]. The authors believed that military service was a risk factor that made for earlier hearing disorders. Studies accomplished in Korea also indicate that «military service» is a factor that exerts substantial influence on hearing loss occurrence [3]. In this respect we should note there is a possibility that people who served in tank units, artillery, or aviation would face discrimination when trying to get a job at a noisy production as employers would be willing to «prevent» occupational SHL occurrence among them.

It is also important to remember that workers' bodies are not exposed solely to

\footnotetext{
${ }^{2}$ I.B. Soldatov. Guide on otorhinolaryngology. Moscow, Medistina Publ., 1997, 608 p. (in Russian).
} 
noise at workplaces; noise is usually combined with other hygienic factors such as vibration, unfavorable microclimate, a wide range of chemicals belonging to different hazard categories etc. Therefore, we can assume that this or that pathological process occurs in a body due to complex exposure to a set of such factors and due to strain in all body systems necessary to maintain optimal homeostasis. Some researchers are right to believe it is important to examine effects produced by chemicals, first of all, those that exert apparent impacts on the central nervous system and cause hearing loss among workers [3]. In this respect, certain amount of attention paid by scientists who examine issues related to hearing loss may be drawn to combined effects produced by noise and chemicals. There are no standards for examining their combined effects and it makes the issue truly vital taking into account rapidly developing chemical industry that involves using newly synthesized and frequently aggressive chemicals.

Despite noise as a physical factor has been studied in detail, there are still uncertainties related to overall effects it produces on a body [33]. Data obtained by some authors on ear noise among people who are exposed to occupational noise seem quite interesting [3]. Researchers believe that ear noise may be the first sign that occupational hearing loss is developing and it can lead to disability in future. The authors collected substantial data via questioning but didn't try to reveal any correlations between this fact and workers' age or working experience; still the fact deserves certain attention. Technological processes as well as prevention activities and work and leisure regimes have their specificity in different industrial branches and agriculture; bearing this in mind, we should remember that there are still issues related to regulating noise and vibration occupational factors, assessing risks, as well as developing activities aimed at their prevention [21, 22, 34].

Given that, when assessing occupational risks caused by adverse effects produced on workers' health by long-term exposure to noise, it is important to take into account that noise, apart from exerting these specific impacts on the hearing organs, has apparent biologic effects on many other organs and systems and significantly inhibits adaptation abilities of a body [35-37].

E.L. Bazarova et al. [38] examined workers employed at a metallurgic enterprise; they had substantial clinical data available for analysis and it allowed them to conclude that exposure to noise was a biological stressor «of a great biological activity and could induce pathology occurrence in many organs and systems in a body». A wide range of negative effects produced by noise on a body has been mentioned in multiple works and proven with research results; these results indicate that people who are exposed to noise and vibration have 1.14 more rapid biological ageing against reference groups and their actual biological age is on average more than 10 years greater [39].

Accomplished studies provided evidence that low frequency noises were highly aggressive and it became apparent via increasing chromosome aberrations in bone marrow cells and higher $n m$ DNA contents in blood plasma [33]. Recent research works allowed establishing that wide-band noise caused functional disorders in a body that involved a wide range of physiological manifestations such as headaches, sleeping disorders, fatigue, irritability, etc., and it resulted in poorer life quality and people's working capacity. It allows taking a broader view on negative effects produced by exposure to noise and not confining it to hearing organs vulnerability. At the same time we should note that even though significant damaging effects produced on drivers' health by exposure to noise were established in a study, their adaptation to this factor turned out to be also quite satisfactory. Subjectively, $64 \%$ of the questioned drivers didn't think noise produced any negative effects on them [40].

Scientific experts tend to have the common opinion on adverse effects produced by 
occupational noise on workers' cardiovascular system regardless of an industry they are employed in [41].

There are data on workers with «noisehazardous» occupations having authentic changes in functional parameters of their cardiovascular system with occurring high cardiovascular risks [41-45]. Obviously, it calls for developing new approaches to substantiating and implementing prevention activities aimed at reducing adverse influence exerted by occupational noise on workers' health.

Recent publications tend to concentrate more and more on physical factors (noise and vibration) and their significant role in hypertension occurrence [42, 46-48]. Experts revealed that noise made the greatest contribution in arterial hypertension developing in workers exposed to a set of adverse occupational factors (noise, vibration, aerosols, static and dynamic loads). These specific effects were also confirmed by results obtained via research that focused on assessing risks of arterial hypertension occurrence under exposure to noise and chemical factors [49].

M.A. Zemlyanova et al. proved there was a correlation between arterial hypertension and noise among workers employed at oreprocessing enterprises; they also established that examined workers had endothelial dysfunction. The authors substantiated certain biomarkers that gave a correct picture of endothelial dysfunction in people who were chronically exposed to noise [50].

We should also note that recent studies have established a direct correlation between arterial hypertension prevalence and duration of exposure to occupational noise [47]. The authors showed that examined workers employed at metallurgic enterprises had arterial hypertension in $24.1 \%$ cases if their working experience was 15 years or longer.

Similar results were obtained by $\mathrm{X}$. Li et al. when they examined more than 5,000 workers exposed to noise louder than $85 \mathrm{dBA}$ at their workplaces: in case working experi- ence was longer than 10 years, workers suffered from both hearing loss and arterial hypertension [51]. We should highlight the conclusion in this work that occupational noise caused high risks of both arterial hypertension and hearing loss among workers aged from 30 to 45. S.A. Eselevich et al. also revealed that workers form this age group had primary SHL in case their average working experience under exposure to occupational noise was equal to 6 years [52]. There are research works that provide evidence on not only SHL occurrence caused by occupational noise depending on working experience but also arterial hypertension and dyslipidemia occurrence in such workers. It allows experts to give well-grounded recommendations on arterial hypertension and dyslipidemia correction and on such activities being included into overall prevention programs aimed at hearing loss prophylaxis [53].

In our opinion, certain attention should be paid to research results obtained by authors who examined more than 250,000 thousand people exposed to noise and their workplaces and concluded that it was arterial hypertension that caused hearing loss [54]. Although the authors themselves believe that the mechanisms behind this established fact is still unclear, we came tentatively assume that arterial hypertension results in hypoxia thus reducing oxygen «supply» to the hearing organ; it makes for certain conditions that lead to hearing loss. This fact can be to a certain extent explained by research works where their authors revealed a role played by stria vascularis in the middle ear homeostasis under hypoxia [55].

We should note that people who work under exposure to noise and vibration tend to have disorders of cardiac and neurohormonal regulation $[42,56]$.

We also think that it was rather important to establish that occupational noise had potentiating effects even if it was at levels below threshold but combined with other chemical occupational factors [36]. Thus, even exposure to noise that was only slightly higher 
than permissible levels but combined with exposure to other hygienic factors, first of all, chemical ones, makes it necessary to include additional estimated data into risk assessment criteria when assessing health risks for workers. These data should also be taken into account when prevention programs are substantiated and periodical medical examinations are accomplished.

Many researchers are becoming more and more active in substantiating a «life quality concept» that is related to health of workers who have to face adverse working conditions at their workplaces. It is done in order to provide better grounds for developing advanced risk management technologies. We should note that people who suffer from occupational hearing loss also tend to have lower activity parameters and to feel themselves not healthy; it exerts both direct and indirect influence on their life quality.

There are data in literature on influence exerted by social factors on hearing loss occurrence and these factors are still not being given proper attention when prevention activities are developed. Thus, Chinese researchers applied meta-analysis procedures to examine more than 30 thousand people; it allowed them to establish a correlation between smoking and hearing loss [2]. The research revealed that smoking was a risk factor that could cause this pathology. Bearing in mind that linear dependence is not always apparent we can still note that the maximum negative effect was detected in examined people with their smoking experience exceeding 15 years (taking into account «dose - response» dependence). The authors substantiate their statement that it is important to develop programs on giving up smoking for people who work under exposure to noise. Another interesting conclusion made by the authors is that long-term smoking is a risk factor that causes high risks of many diseases; combined, these diseases may result in hearing loss among workers exposed to elevated occupational noise.

Contemporary demographic processes involve an increase in life expectancy and a decrease in birth rate in Russia; it leads to disproportion in labor resources and social strain. Ultimately, it resulted in retirement age increase. Hygienic science unavoidably has to examine and substantiate effects produced by adverse hygienic factors under long-term exposure regulated by relevant standards and documents. Accomplished studies revealed that in case all significant sanitary-hygienic factors were improved, physical factors held the second rank place as per their contribution made into life expectancy [5].

When assessing adverse effects produced by noise on workers employed in different industries and its contribution into hearing loss, it is necessary to take into account the fact that as working experience becomes longer, developing damages to the hearing organs are aggravated by age-related changes in workers [57].

In scientific literature there are also data on influence exerted by nutrition (metabolic factor) on hearing loss development. There are quite interesting studies accomplished by Korean scientists who examined a correlation between dietary nutrition and hearing loss among elderly people aged 65 . For 3 years 4,742 people underwent a profound medical examination that included audiologic assessment and analysis of their nutrition [58]. To provide a homogenous sampling, the authors took into account body mass index, smoking status, alcohol intake as well as diabetes and arterial hypertension in case history. Results obtained via this 3-year examination allowed establishing a correlation between hearing loss and riboflavin, niacin, and retinol consumption with food. Only one group out of all examined people consumed them in optimal quantities recommended by the $\mathrm{WHO}$, and it allowed the authors to conclude that they were efficient in hearing loss prophylaxis as well as to state that it was possible to use these substances within the overall system for hearing loss prevention.

There are also data on positive effects produced by polyvitamins consumption on 
hearing improvement in examined people [59]. Studies accomplished by British scientists also provide indirect confirmation that alimentary factor plays an important role in hearing loss. In some research greater hearing loss prevalence was detected among people with lower social status and it was related to poorer nutrition quality [31].

Conclusions. Our literature analysis has allowed us to conclude that issues related to adverse impacts exerted by exposure to noise both on the hearing organs and basic body systems are still vital at present. Hearing loss is a problem not only for occupational medicine but it is also an economic and social one. Finding solutions to it will to a great extent contribute not only into improving life quality of workers who are employed at noise-hazardous productions but also into increasing life expectancy of workers employed in leading industrial brunches in the country and making «blue-collar» occupations more prestigious.

Growing life expectancy and an increase in retirement age are necessarily connected to longer working experience under exposure to noise and it will naturally aggravate the considered problem.

A growing period of exposure to a set of occupational factors, noise included, and changing social factors require additional studies on examining the whole range of occupational risks caused by influence exerted by noise on a whole body and the hearing organs in particular. It is also necessary to provide scientific grounds for advanced technologies development within a system for hearing loss prevention and workers' health preservation as it will result in more stable situation with labor potential in leading industrial brunches.

Providing comfortable occupational and social conditions for workers should be viewed as a vital trend in scientific research in the sphere of hygiene and occupational medicine in accordance with primary tasks set with state strategies.

Funding. The research was not granted any sponsor support.

Conflict of interests. The authors declare there is no any conflict of interests.

\section{References}

1. Zheglova A.V. Personalized occupational risk and longevity. Meditsina truda i promyshlennaya ekologiya, 2019, vol. 59, no. 9 - C. 627-628 (in Russian).

2. Li X., Rong X., Wang Z., Lin A. Association between Smoking and noise-induced Hearing Loss: Meta-Analysis of Observational Stadies. Int. J. Environ. Res. Public Health, 2020, vol. 17, no. 4, pp. 1201. DOI: 10.3390/ijerph17041201

3. Kim K.S. Occupational Hearing Loss in Korea. J. Korean Med Sci, 2010, vol. 25, pp. 62-69. DOI: $10.3346 / \mathrm{jkms} .2010 / 25 . \mathrm{S} 62$

4. Bukhtiyarov I.V., Izmerov N.F., Tikhonova G.I., Churanova A.N., Gorchakova T.Yu., Bryleva M.S., Krutko A.A. Work conditions as a risk factor mortality increase in able-bodied population. Meditsina truda i promyshlennaya ekologiya, 2017, no. 8, pp. 43-49 (in Russian).

5. Popova A.Yu., Zaitseva N.V., Onishchenko G.G., Kleyn S.V., Glukhikh M.V., Kamaltdinov M.R. Social and economic determinants and potential for growth in life expectancy of the population in the Russian Federation taking into account regional differentiation. Health Risk Analysis, 2020, no. 1, pp. 4-17 (in Russian). DOI: 10.21668/health.risk/2020.1.01.eng

6. Valeeva E.T., Bakirov A.B., Shaikhlislamova E.R. About the reasons of low detection of occupational diseases in the republic of Bashkortostan. Meditsina truda i promyshlennaya ekologiya, 2019, vol. 59, no. 9, pp. 578-579 (in Russian).

7. Panova I.V., Lashina E.L., Pakseeva V.S. The results of periodic medical examinations in the central Federal district 2016-2018. Meditsina truda i promyshlennaya ekologiya, 2019, vol. 59, no. 9, pp. 716 (in Russian).

8. Panova I.V., Chernov O.E., Pfaff V.F. Mandatory medical examinations as a method of prevention. Meditsina truda i promyshlennaya ekologiya, 2019, vol. 59, no. 9, pp. 717 (in Russian). 
9. Pankova V.B., Vil'k M.F., Daikhes N.A. Hearing loss from noise exposure is an urgent problem of occupational medicine. Meditsina truda i promyshlennaya ekologiya, 2019, vol. 59, no. 9, pp. 713-714 (in Russian).

10. Atamanchuk A.A., Kabanova T.G. Difficulties in diagnosis of occupational diseases in Russia. Meditsina truda i promyshlennaya ekologiya, 2017, no. 9, pp. 11-12 (in Russian).

11. Berkheeva Z.M. Problems of providing occupational health care to employees of agroindustrial complex. Meditsina truda i promyshlennaya ekologiya, 2019, vol. 59, no. 9, pp. 567-568 (in Russian).

12. Gazizov O.M., Amanbekova A.U. Professional sensorineural hearing loss in coal miners. Meditsina truda i promyshlennaya ekologiya, 2019, vol. 59, no. 9, pp. 594-595 (in Russian).

13. Tikhonova I.V. The role of performing and periodical profound medical examinations in the development prevention of occupational hearing disorders. Byulleten' VSNTs SO RAMN, 2005, vol. 40, no. 2, pp. 92-94 (in Russian).

14. Adeninskaya E.E., Simonova N.I., Mazitova N.N., Nizyaeva I.V. The principles of noise induced hearing loss diagnostics in modern Russia (systematic review). Vestnik sovremennoi klinicheskoi meditsiny, 2017, vol. 10, no. 3, pp. 48-55 (in Russian).

15. Chebotarev A.G., Bulgakova N.V., Khakimova O.O. Gigienicheskaya otsenka shuma i patologii organa slukha $\mathrm{u}$ rabochikh gorno-metallurgicheskikh predpriyatii [Hygienic assessment of noise and acoustic apparatus pathologies among workers employed at mining and metallurgical enterprises]. Gornaya promyshlennost', 2017, vol. 132, no. 2, pp. 64-66 (in Russian).

16. Professional'nye zabolevaniya [Occupational diseases]. In: N.F. Izmerov [et al.] eds. Moscow, 1996, vol. 1, 336 p. (in Russian).

17. Garipova R.V., Safina K.R., Nigmatullina G.R. Structure of occupational morbidity of employees of a large machine-building enterprise. Meditsina truda i promyshlennaya ekologiya, 2019, vol. 59, no. 9, pp. 596-597 (in Russian).

18. Fedina I.N., Preobrazhenskaya E.A. Features of noise-induced hearing loss in modern conditions. Meditsina truda i promyshlennaya ekologiya, 2017, no. 9, pp. 200-201 (in Russian).

19. Trofimova K.I., Gibadulina I.Yu., Bulgakova M.V. Pharmacotherapy for combined cardiovascular pathology and occupational neurosensory deafness in workers exposed to noise. Meditsina truda i promyshlennaya ekologiya, 2017, no. 9, pp. 194-195 (in Russian).

20. Bezrukova G.A., Novikova T.A., Shalashova M.A. The role of vibro-acoustic factor in formation of occupational morbidity of agricultural workers. Meditsina truda i promyshlennaya ekologiya, 2017, no. 9, pp. 22-23 (in Russian).

21. Vil'k M.F., Pankova V.B., Kaptsov V.A. Traffic noise as a risk factor for occupational deafness (exemplified by air and railway transport). Meditsina truda i promyshlennaya ekologiya, 2017, no. 9, pp. 36-37 (in Russian).

22. Tyurin A.V., Vyal'tsina N.E., Kulbaisov A.M. Occupational morbidity in the Orenburg region. Meditsina truda i promyshlennaya ekologiya, 2019, vol. 59, no. 9, pp. 780-781 (in Russian).

23. Romeiko V.L., Ivleva G.P. Hygienic assessment of acoustic load on flight crew members of civil aircrafts. Meditsina truda i promyshlennaya ekologiya, 2017, no. 9, pp. 161 (in Russian).

24. Adeninskaya E.E., Simonova N.I., Savel'ev A.A., Mukharamova S.S. Auditory threshold raising dependence on production risk factors in air crew members. Vestnik sovremennoi klinicheskoi meditsiny, 2018, vol. 11, no. 1, pp. 17-22 (in Russian).

25. Pankova V.B., Fedina I.N., Volgareva A.D. Professional'naya neirosensornaya tugoukhost': diagnostika, profilaktika, ekspertiza trudosposobnosti [Occupational sensorineural hearing loss: diagnostics, prevention, and working capacity examination]. In: I.A. Doikhes ed. Moscow, Izdatel'skotorgovaya korporatsiya «Dashkov i Ko» Publ., 2017, 330 p. (in Russian).

26. Volgareva A.D., Karimov L.K., Bakirov A.B., Shaikhlislamova E.R., Gimranova G.G., Muldasheva N.A., Chudkovets G.M., Gazizova N.R., Faizullina G.N. Relevant problems of early diagnosis of neuro-sensor hearing loss in petrochemical workers. Meditsina truda i ekologiya cheloveka, 2019, no. 1, pp. 5-10 (in Russian). 
27. Pankova V.B., Fedina I.N., Bomshtein N.G., Volokhov L.L., Serebryakov P.V. The modern principles of rehabilitation of hearing disorders in workers of noise occupations. Zdravookhranenie Rossiiskoi Federatsii, 2018, vol. 62, no. 3, pp. 147-151 (in Russian).

28. Ereniev S.I., Plotnikova O.V. Adaptive potential of the circulatory system in patients with vibration disease and sensorineural hearing loss. Meditsina truda i ekologiya cheloveka, 2019, vol. 59, no. 9, pp. 623-624 (in Russian).

29. Luzhetskii K.P.., Ustinova O.Yu., S.V. Kleyn, Koshurnikov D.N., Vekovshinina S.A., Chigvintsev V.M. Peculiarities of production-related diseases in miners employed at deep mining of chromic ores. Meditsina truda i promyshlennaya ekologiya, 2018, no. 10, pp. 12-16 (in Russian).

30. Popova O.A., Goncharova I.G., Kartysheva S.I. Problems auditory fatigue and auditory adaptation in children and adolescents. Materialy V Vserossiiskoi konferentsii «Novoi shkole zdorovye deti», 2018, pp. 130-132 (in Russian).

31. Dawes P., Fortnum H., Moore D.R., Emsley R., Norman P., Cruickshanks K., Devis A. [et al.]. Hearing in middle age: a population snapshot of 40-69 year old in the UK. Ear Hear, 2014, vol. 35, no. 3, pp. e44-e51. DOI: 10.1097/AUD.0000000000000010

32. Churkin D.V., Lastkov D.O., Antropova O.S. Evaluation of the expression of hearing disorders in participants of a local military conflict with preceding work experience in conditions of production noise. Meditsina v Kuzbasse, 2018, vol. 17, no. 2, pp. 9-14 (in Russian).

33. Vasil'eva I.N., Bespalov V.G., Zinkin V.N. Low-frequency noise as a hazard increasing occurrence of chromosomal aberrations and promoting cell death. Meditsina truda i promyshlennaya ekologiya, 2017, no. 3, pp. 22-26 (in Russian).

34. Prokopenko L.V., Kravchenko O.K., Kur'erov N.N. Problems of regulation for noise and vibration influence on automobile drivers and prevention measures. Meditsina truda i promyshlennaya ekologiya, 2017, no. 9, pp. 158-159 (in Russian).

35. Concha-Barrientos M., Camobell-Lendrum D., Steenlend H. Occupational noise: assessing the burden of disease from work-related hearing impairment at national and local levels. WHO Enviromental Burden of Diseases Series. Geneva, World Health Organization Publ., 2004, no. 9, pp. 41 (in Russian).

36. Vasyutkina D.I. Proizvodstvennyi shum i ego vliyanie na organism cheloveka [In-plant noise and its impacts on a human body]. Vestnik BGTU im. V.G. Shukhova, 2013, no. 1, pp. 125-128 (in Russian).

37. Denisov E.I., Chesalin P.V. Nonspecific effects of noise expo-sure. Gigiena i sanitariya, 2007, no. 6, pp. 54-57 (in Russian).

38. Bazarova E.L., Fedoruk A.A., Roslaya N.A., Osherov I.S., Babenko A.G. Assessment of occupational risk caused by noise exposure in workers at metallurgical plant subunits under modernization. Meditsina truda i promyshlennaya ekologiya, 2019, vol. 59, no. 3, pp. 142-148 (in Russian).

39. Ereniev S.I. Plotnikov O.V. Biological age and rates of aging of patients with vibration disease and bilateral sensorineural hearing loss. Meditsina truda i promyshlennaya ekologiya, 2019, vol. 59, no. 9, pp. 624-625 (in Russian).

40. Klimova M.G., Khristoforova N.K. Physical influence of noise on drivers health. Vestnik RUDN. Seriya: Ekologiya i bezopasnost' zhiznedeyatel'nosti, 2012, no. 1, pp. 38-46 (in Russian).

41. Nosov A.E., Baidina A.S., Vlasov E.M., Alekseev V.B. Analysis of the heart rate variability in cardiac abnormalities in workers employed in oil production. Gigiena i sanitariya, 2016, vol. 95, no. 1, pp. 41-45 (in Russian).

42. Melent'ev A.V., Serebryakov P.V., Shcheglova A.V. Influence of noise and vibration on nervous regulation of heart. Meditsina truda i promyshlennaya ekologiya, 2018, no. 9, pp. 19-23 (in Russian).

43. Popov M.N. Vascular factor in development of professional neurotouch relative deafness. Rossiiskaya otorinolaringologiya, 2014, vol. 68, no. 1, pp. 182-183 (in Russian).

44. Melent'ev A.V., Serebryakov P.V. The role of physical factors of the working environment in the formation of arterial hypertension. Meditsina truda i promyshlennaya ekologiya, 2019, vol. 59, no. 9, pp. 692-693 (in Russian).

45. Izmerov N.F., Bukhtiyarov I.V., Ermakova M.A., Shpagina A.A. Features of hemostasis system and vascular epithelium growth factor in arterial hypertension with high occupational risk. Meditsina truda i promyshlennaya ekologiya, 2014, no. 3, pp. 1-6 (in Russian). 
46. Preobrazhenskaya E.A., Sukhova A.V., Izmailova O.A. Clinical and functional state of cardiovascular system in workers exposed to noise and vibration. Meditsina truda i promyshlennaya ekologiya, 2017, no. 9, pp. 158 (in Russian).

47. Tiunova M.I., Vlasova E.M., Nosov A.E., Ustinova O.Yu. Influence of industrial noise on the development of arterial hypertension in workers of metallurgical manufactures. Meditsina truda $i$ promyshlennaya ekologiya, 2020, vol. 60, no. 4, pp. 264-267 (in Russian).

48. Atamanchuk A.A., Dmitruk L.I., Gorenkov R.V. The role of adverse occupational factors in the formation of hypertension in workers. Meditsina truda i promyshlennaya ekologiya, 2019, vol. 59, no. 9, pp. 546-547 (in Russian).

49. Fedina I.N., Serebryakov P.V., Smolyakova I.V., Melent'ev A.V. Evaluation of arterial hypertension risk under exposure to noise and chemical occupational hazards. Meditsina truda i promyshlennaya ekologiya, 2017, no. 2, pp. 21-26 (in Russian).

50. Zemlyanova M.A., Zaitseva N.V., Kir'yanov D.A., Shlyapnikov D.M., Lebedeva T.M. Biomarkers of work-related endothelial dysfunction in employees of ore-dressing production occupied in conditions of long-term noise exposure. Gigiena i sanitariya, 2017, vol. 96, no. 1, pp. 56-62 (in Russian).

51. Li X., Dong Q., Wang B., Songan H., Zhu B. The Influence of Occupational Noise Exposure on Cardiovascular and Hearing Conditions among Industrial Workers. Sci. Rep., 2019, vol. 9, pp. 11524. DOI: 10.1038/541598-019-47901-2

52. Eselevich S.A., Balunov V.D., Kolesnikova V.A. Principles of formation of risk groups among employees at the enterprise in the Leningrad region. Meditsina truda i promyshlennaya ekologiya, 2019, vol. 59, no. 9, pp. 625-626 (in Russian).

53. Pfaf V.F., Gorokhova S.G., Luzina K.E., Yanushkina E.S., Prigorovskaya T.S., Muraseeva E.V., Dragin S.P., At'kov A.Yu. Occupational deafness in workers of locomotive crew and its association with risk factors. Meditsina truda i promyshlennaya ekologiya, 2016, no. 2, pp. 33-37 (in Russian).

54. Wang B., Han L., Dai S., Li X., Cai W., Yang D., Chen L., Wang N., Zhu B., Zhang J. Hearing Loss Characteristics of Workers with Hypertension Exposed to Occupational Noise: A Cross-Sectional Study of 270,033 Participants. Hindawi BioMed Research International, 2018, vol. 2018 , pp. 7. DOI: $10.1155 / 2018 / 8541638$

55. Ciuman R.R. Stria vascularis and vestibular dark cells: characterization of main structures responsible for homeostasis, and their pathophysiological relations. The Journal of Laryngology \& Otology, 2009, vol. 123, no. 2, pp. 151-162. DOI: 10.1017/S0022215108002624

56. Lapko I.V., Kir'yakov V.A., Pavlovskaya N.A., Zheglova A.V., Oshkoderov O.A. The impact of physical factors on the complex neurohormonal regulation of workers in mining and engineering. Sanitarnyi vrach, 2015, no. 2, pp. 9-15 (in Russian).

57. Dobie R.A. The burdens of age-related and occupational noise-induced hearing loss in the United States. Ear Hear, 2008, vol. 29, no. 4, pp. 565-577. DOI: 10.1097/AUD.0b013e31817349ec

58. Kim T.S., Chung J.W. Associations of Dietary Riboflavin, Niacin, and Retinol with Agerelated Hearing Loss; An Analysis of Korean National Health and Nutrition Examination Survey Data. Nutrients, 2019, vol. 11, no. 4, pp. 896. DOI: 10.3390/nu11040896

59. Spankovich C., Li Prell C.G. Healthy diets, healthy hearing: National health and nutrition examination survey, 1999-2002. Int. J. Audiol., 2013, vol. 52, no. 6, pp. 369-376. DOI: $10.3109 / 14992027.2013 .780133$

Spirin V.F., Starshov A.M. On certain issues related to chronic exposure to occupational noise and impacts exerted by it on workers' bodies (literature review). Health Risk Analysis, 2021, no. 1, pp. 185-194. DOI: 10.21668/health.risk/2021.1.19.eng

Received: 06.11.2020

Accepted: 03.03.2021

Published: 30.03 .2021 